\title{
EFEITO DO POTÁSSIO NO CRESCIMENTO, NAS CONCENTRAÇÕES DOS NUTRIENTES E NAS CARACTERÍSTICAS DA MADEIRA JUVENIL DE PROGÊNIES DE Eucalyptus grandis W. Hill ex Maiden CULTIVADAS EM SOLUÇÃO NUTRITIVA
}

\author{
RONALDO LUIZ VAZ DE ARRUDA SILVEIRA \\ Engenheiro Florestal
}

Orientador: Prof. Dr. Eurípedes Malavolta

\begin{abstract}
Tese apresentada à Escola Superior de Agricultura
"Luiz de Queiroz", Universidade de São Paulo, para obtenção do título de Doutor em Agronomia, Área de Concentração: Solos e Nutrição de Plantas.
\end{abstract}

P I R A C I C A B A

Estado de São Paulo - Brasil

Fevereiro - 2000 


\section{ERRATA}

1) No texto em vez de ler Stape et al. (1992), leia Stape (1992).

2) No texto em vez de ler Bellote et al. (1979), leia Bellote (1979).

3) Na página 1, em vez de ler ANFPC (1996), leia ANFPC (1995).

4) Na página 36, segunda linha: em vez de ler somente $5 \mathrm{ml}$ de ácido perclórico, leia $5 \mathrm{ml}$ de ácido perclórico 5\%.

5) No item referência bibliográficas, incluir:

ANFPC - A política de desenvolvimento do complexo celulose-papel: 1995-2005, sumário executivo, São Paulo, 1995. 92p.

DELL, B. Copper nutrition of Eucalyptus maculata Hook. seedlings: requirements for growth, distribution of copper and the diagnosis of copper deficiency. Plant and Soil, v.16, n.2, p.181-187, 1994.

TURNBULL, C.R.A.; BEADLE, C.L.; WEST, P.W.; CROMER, R.N. Copper deficiency a probable cause of stem deformity in fertilised Eucalyptus nitens. Canadian Journal of Forest Research, V.24, n.7, p.1434-1439, 1994.

GONÇALVES, J.L.M. Recomendação de adubação para Eucalyptus, Pinus e Espécies Típicas da Mata Atlântica. Documentos Florestais, n.15, p.123, 1995. 
Dados Internacionais de Catalogação na Publicação (CIP)

DIVISĀO DE BIBLIOTECA E DOCUMENTAÇĀO - Campus "Luiz de Queiroz"/USP

\author{
Silveira, Ronaldo Luiz Vaz de Amuda \\ Efeito do potássio no crescimento, nas concentrações dos nutrientes e nas caracteristicas \\ da madeira juvenil de progênies de Eucalyptus grandis W. Hill ex Maiden cultivadas em \\ soluçāo nutritiva / Ronaldo Luiz Vaz de Arruda Silveira. - - Piracicaba, 2000. \\ 169 p. : il. \\ Tese (doutorado) - Escola Superior de Agricultura Luiz de Queiroz, 2000. \\ Bibliografia. \\ 1. Eucalipto 2. Madeira juvenil 3. Nutriçāo vegetal 4. Potássio 5. Progênie vegetal 6. \\ Propriedade fisico-quimica 7. Química do solo 8. Soluçāo nutritiva I. Título
}

CDD 634.9734

\title{
-Permitida a copia total ou parcial deste documento, desde que citada a fonte $=0$ autor
}




\section{AGRADECIMENTOS}

Ao Prof. Dr. Eurípedes Malavolta, pela orientação, paciência e confiança durante o desenvolvimento deste trabalho.

Ao Departamento de Solos e Nutrição de Plantas, da Escola Superior de Agricultura "Luiz de Queiroz" (ESALQ/USP) e ao Centro de Energia Nuclear na Agricultura (USP) pela oportunidade da realização deste trabalho.

À FAPESP (Proc. 97/066626-4) pelos recursos financeiros fornecidos para realização do trabalho.

Ao Conselho Nacional de Pesquisa (CNPQ) pela concessão da bolsa.

A Cleusa Pereira Cabral pelo auxilio e ensinamento nas análises químicas e amizade.

A Companhia Suzano de Papel e Celulose na pessoa do Eng. Shinitiro Oda e Eng. Eduardo José de Mello pelo fornecimento do material genético.

Aos amigos Alberto Laranjeiro, Edward Fagundes Branco, Klaus Barreto, Mônica Brito, Renata Evangelista, Rubens Louzada, Vanderlei Benedetti, Vítor Fessel e Zezé.

Aos mais que amigos e companheiros de trabalho Marco Antonio Camargo, Juliana Bouchardet, Fábio Sgarbi, Teluíra Andrade, Caio Zanardo, Ricardo Cassamassimo, Prof. Antonio Natal Gonçalves e Prof. Hilton Thadeu Zarate do Couto.

Aos mais que amigos Dri, Fer, Pedro, Eliana, Mirian, Airton, Gláucia e Lúcia. 
Aos parceiros de trabalho e acima de tudo, amigos Edson Namita Higashi e Adônis Moreira.

Aos colegas de pós graduação João Alberto, Reges e Ricardo pelo incentivo e amizade.

Ao professor Francides Gomes, Regina Buch e Udemilson Luis Cerebelli do Departamento de Ciências Florestais pelo auxilio na interpretação das análises de madeira

Ao professor Fernando Broetto, professora Giuseppina Pace Pereira Lima e Vânia Aparecida de Oliveira do Departamento de Bioquímica da Unesp/Botucatu pelo auxílio nas análises de poliaminas e açúcares.

Ao professor José Raimundo Passos e a professora Liciana Vaz de Arruda Silveira Chalita do Departamento de Bioestatística da Unesp/Botucatu pelo auxílio nas análises estatísticas.

A professora Siu Mui Tsai do CENA/USP pelo uso de liofilizador.

A todos aqueles que direta ou indiretamente contribuiram para a realização deste trabalho. 


\section{OFEREÇO:}

A meu grande pai "Ronaldão" em todos os sentidos, a minha querida mãe Luizoca, a minha irmã "Li". Em especial a minha sempre e querida "Preta" (Má), sem os quais não seria possível a realização deste trabalho.

Aos meus queridos sobrinhos Letícia, Larissa, Bianca, Vivian, Thalissa, Rafael e Bruno pela felicidade proporcionada.

DEDICO. 


\section{SUMÁRIO}

Página

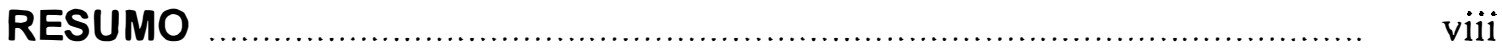

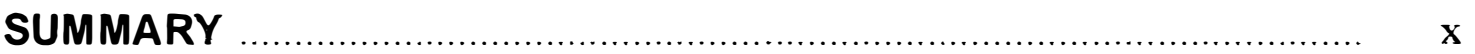

1 INTRODUÇÃO …............................................................................ 1

2 REVISÃO DE LITERATURA ….......................................................... 3

2.1 Funções do potássio na planta ....................................................... 3

2.2 Sintomas de deficiência de potássio ................................................... 5

2.3 Soluções nutritivas usadas no cultivo de Eucalyptus ............................ 5

2.4 Exigências nutricionais do Eucalyptus em relação ao potássio .................. 7

2.4.1 Conteúdo e eficiência de utilização de potássio …............................. 7

2.4.2 Concentração de potássio e outros nutrientes nas partes da planta ...... 11

2.4.3 Faixas adequadas e deficientes dos nutrientes............................ 13

2.4.4 Interações entre potássio e outros nutrientes ................................ 16

2.5 Interações entre sulfato, cloreto e nitrato ......................................... 17

2.6 Resposta do Eucalyptus à aplicação de potássio................................... 17

2.7 Relação entre o potássio e a putrescina, espermidina, espermina ............... 20

2.8 Efeitos da adubação e do estado nutricional sobre as características

fisicas, anatômicas e químicas da madeira ......................................... 23

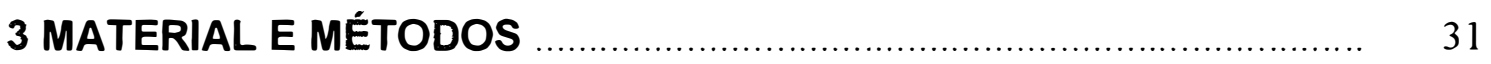

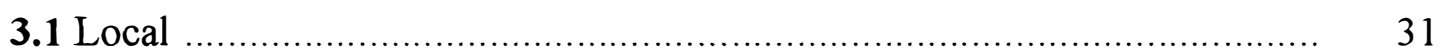

3.2 Escolha das progênies de Eucalyptus grandis .................................... 31

3.3 Obtenção e avaliação das mudas ...................................................... 31

3.4 Cultivo das plantas em solução nutritiva .......................................... 32

3.5 Avaliações, colheita e preparo de material para a análise química ........... 34

3.6 Análise química do tecido vegetal .............................................. 35

3.7 Análise bioquímica das folhas .................................................. 35

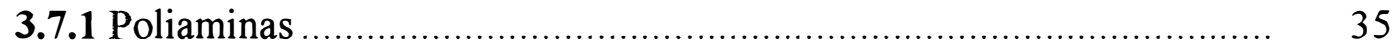




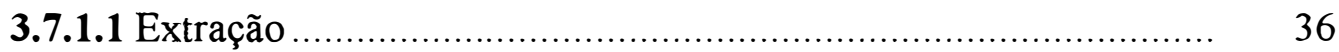

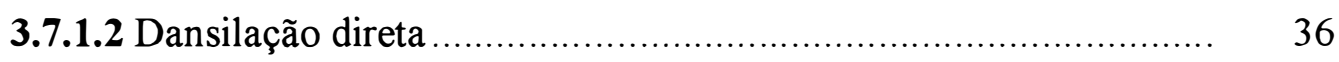

3.7.1.3 Separação das poliaminas por cromatografia de camada delgada $\quad 36$

3.7.1.4 Análise quantitativa de poliaminas separadas na cromatografia de camada delgada ............................................................... 37

3.7.2 Açúcares solúveis totais ............................................................. 37

3.8. Características da madeira ................................................................ 37

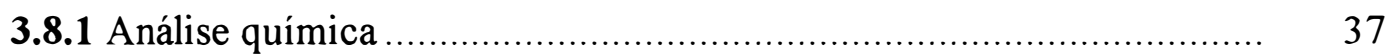

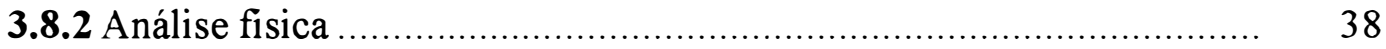

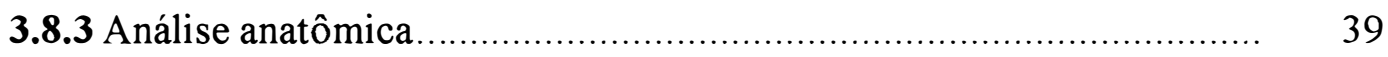

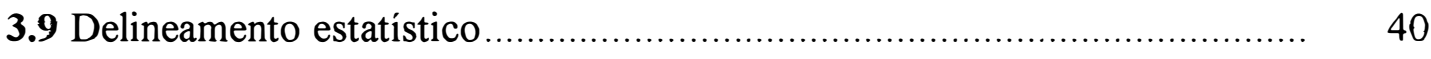

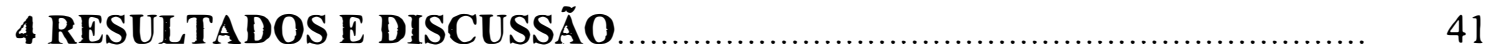

4.1 Caracterização das mudas das progênies de Eucalyptus grandis ............... 41

4.1.1 Produção de matéria seca .............................................................. 41

4.1.2 Concentração dos macro e micronutrientes ........................................ 42

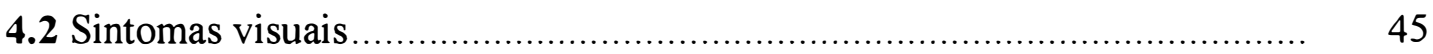

4.2.1 Deficiência de potássio ................................................................ 45

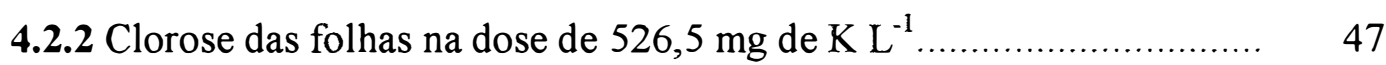

4.3 Desenvolvimento das plantas ........................................................... 48

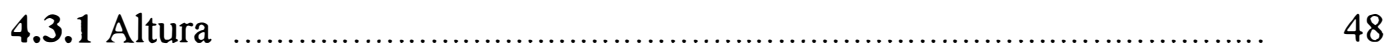

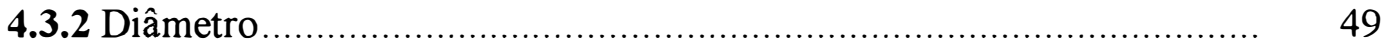

4.3.3 Produção de matéria seca ............................................................... 51

4.4 Estado nutricional das progênies de Eucalyptus grandis .......................... 59

4.4.1 Concentração dos macronutrientes em função das progênies .............. 59

4.4.2 Efeito das doses de potássio sobre a concentração dos macronutrientes 64

4.4.3 Concentração dos micronutrientes em função das progênies................ 71

4.4.4 Efeito das doses de potássio sobre a concentração dos micronutrientes 73

4.4.5 Relação entre a concentração de potássio nos tecidos vegetais e a

produção de matéria seca lenhosa e total.......................................... $\quad 75$ 
4.4.6 Relação entre $\mathrm{N} / \mathrm{K}, \mathrm{K} / \mathrm{P}, \mathrm{K} / \mathrm{Ca}, \mathrm{K} / \mathrm{Mg}$ e $\mathrm{K} / \mathrm{Ca}+\mathrm{Mg}$ nas folhas diagnóstico e a produção de matéria seca lenhosa

4.5 Acúmulo de nutrientes nas progênies de Eucalyptus grandis .................... $\quad 89$

4.5.1 Acúmulo dos macronutrientes em função das progênies...................... 89

4.5.2 Acúmulo dos macronutrientes em função das doses de potássio ......... 92

4.5.3 Acúmulo dos micronutrientes em função das progênies...................... 94

4.5.4 Acúmulo dos micronutrientes em função das doses de potássio.......... 96

4.6 Eficiência de utilização de K pelas progênies de Eucalyptus grandis ......... 98

4.6.1 Produção de matéria seca total e lenhosa ............................................ 98

4.6.2 Produção de holocelulose ............................................................. 100

4.7 Putrescina e poliaminas .................................................................. 102

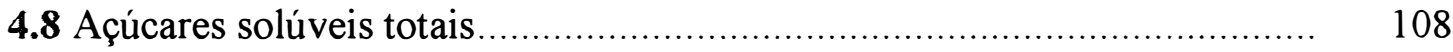

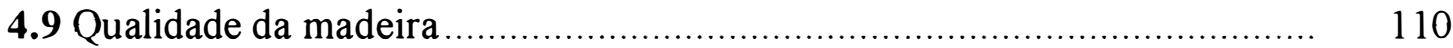

4.9.1 Densidade básica ....................................................................... 110

4.9.1.1 Efeito das progênies e das doses de potássio ............................. 110

4.9.1.2 Efeito da concentração de potássio e dos macronutrientes nas

folhas diagnóstico e no lenho

4.9.1.3 Efeito das relações $\mathrm{N} / \mathrm{K}, \mathrm{K} / \mathrm{P}, \mathrm{K} / \mathrm{Ca}, \mathrm{K} / \mathrm{Mg}$ e $\mathrm{K} / \mathrm{Ca}+\mathrm{Mg}$

nas folhas diagnóstico e no lenho

4.9.2 Parâmetros anatômicos ...................................................................... 118

4.9.2.1 Comprimento e largura das fibras .......................................... 118

4.9.2.1.1 Efeito das progênies e das doses de potássio ...................... 118

4.9.2.1.2 Efeito da concentração de potássio e dos macronutrientes nas folhas diagnóstico e no lenho ............................................ 121

4.9.2.1.3 Efeito das relações $\mathrm{N} / \mathrm{K}, \mathrm{K} / \mathrm{P}, \mathrm{K} / \mathrm{Ca}, \mathrm{K} / \mathrm{Mg}$ e $\mathrm{K} / \mathrm{Ca}+\mathrm{Mg}$ nas folhas diagnóstico e no lenho

4.9.2.2 Diâmetro do lume, espessura e fração parede.

4.9.2.2.1 Efeito das progênies e das doses de potássio

4.9.2.2.2 Efeito da concentração de potássio e dos macronutrientes nas folhas diagnóstico e no lenho. 
4.9.2.2.3 Efeito das relações $\mathrm{N} / \mathrm{K}, \mathrm{K} / \mathrm{P}, \mathrm{K} / \mathrm{Ca}, \mathrm{K} / \mathrm{Mg}$ e $\mathrm{K} / \mathrm{Ca}+\mathrm{Mg}$ nas folhas diagnóstico e no lenho

4.9.3 Parâmetros químicos ............................................................ 134

4.9.3.1 Efeito das progênies e das doses de potássio ............................ 134

4.9.3.2 Efeito da concentração de potássio e dos macronutrientes nas folhas diagnóstico e no lenho ............................................. 139

4.9.3.3 Efeito das relações $\mathrm{N} / \mathrm{K}, \mathrm{K} / \mathrm{P}, \mathrm{K} / \mathrm{Ca}, \mathrm{K} / \mathrm{Mg}$ e $\mathrm{K} / \mathrm{Ca}+\mathrm{Mg}$ nas folhas diagnóstico e no lenho

4.10 Relação entre açúcares solúveis totais nas folhas diagnóstico e a holocelulose no lenho em função das doses de potássio 148

5 CONCLUSÕES 149 REFERÊNCIAS BIBLIOGRÁFICAS 151 


\title{
EFEITO DO POTÁSSIO NO CRESCIMENTO, NAS \\ CONCENTRAÇÕES DOS NUTRIENTES E NAS \\ CARACTERÍSTICAS DA MADEIRA JUVENIL DE PROGÊNIES \\ DE Eucalyptus grandis W. Hill ex Maiden CULTIVADAS EM \\ SOLUÇÃO NUTRITIVA
}

\author{
Autor: Ronaldo Luiz Vaz de Arruda Silveira \\ Orientador: Prof. Dr. Eurípedes Malavolta
}

\section{RESUMO}

O estudo teve por objetivo determinar os efeitos do potássio sobre o crescimento, concentração dos nutrientes, açúcares solúveis totais, diamina putrescina e as poliaminas espermina e espermidina e as características fisicas, químicas e anatômicas da madeira de quatro progênies de Eucalyptus grandis, bem como avaliar os genótipos quanto a eficiência de utilização de potássio.

As plantas foram cultivadas até 67 dias após o transplantio em solução nutritiva contendo $175,5 \mathrm{mg}$ de $\mathrm{K} \mathrm{L}^{-1}$. A partir dessa idade, iniciou-se o cultivo das progênies em quatro doses de potássio $\left(0,58,5,175,5\right.$ e $\left.526,5 \mathrm{mg} \mathrm{L}^{-1}\right)$. As soluções nutritivas foram trocadas quinzenalmente. As plantas foram mensuradas mensalmente em altura e diâmetro. Aos 9 meses de cultivo nas doses de potássio, fez-se uma amostragem das folhas diagnóstico ( $5^{\underline{a}}$ e $6^{\underline{a}}$ folha a partir do ápice dos ramos) para a determinação da concentração de açúcares solúveis totais, putrescina, espermidina e espermina. Passado dez meses de cultivo nas doses de potássio, as plantas foram colhidas e separadas em folhas novas, folhas diagnóstico, folhas velhas, ramos, casca e lenho. Posteriormente, cada parte da planta foi colocada em saco de papel identificado e levada para secagem em estufa até atingir peso constante. Após a moagem foram determinadas as concentrações de $\mathrm{N}, \mathrm{P}, \mathrm{K}, \mathrm{Ca}, \mathrm{Mg}, \mathrm{S}, \mathrm{B}, \mathrm{Cl}, \mathrm{Cu}, \mathrm{Fe}, \mathrm{Mn}$ e Zn. 
Nas amostras do lenho foram realizadas análises anatômicas para a quantificação do comprimento, largura, diâmetro do lume, espessura e fração parede das fibras. Análises químicas foram feitas para determinar a concentração de holocelulose, extrativos e lignina. Determinou-se também a densidade básica do lenho em três posições do caule (ápice, meio e base).

Nas condições experimentais as principais conclusões foram que para a produção de lenho, os materiais genéticos de $E$. grandis responderam de maneira diferenciada a aplicação de potássio, sendo as progênies 2 e 3 consideradas responsivas e as progênies 1 e 4 não responsivas. A faixa adequada de $\mathrm{K}$ nas folhas usadas para diagnose variou em função do material genético analisado. As progênies apresentaram respostas diferenciadas quanto a utilização de potássio para a produção de lenho e holocelulose. A progênie 2 foi considerada a menos eficiente. A deficiência de $\mathrm{K}$ acarretou num acúmulo tóxico de putrescina nas folhas diagnóstico de todas as progênies. Nas progênies 1 e 3, o aumento da dose de $\mathrm{K}$ na solução proporcionou decréscimos na concentração de açúcares nas folhas diagnóstico. As progênies tiveram comportamentos diferenciados para a densidade básica do lenho conforme variou-se a dose de potássio na solução nutritiva. As maiores doses de potássio na solução proporcionaram aumento no comprimento e na largura das fibras dos genótipos, com exceção da progênie 1. Na mesma progênie, houve decréscimo na espessura da parede com o aumento da dose de potássio. Nas progênies 2 e 3, as doses de potássio na solução nutritiva causaram aumento do diâmetro do lume das fibras. Houve redução da fração parede das fibras das progênies 1, 2 e 3 com o aumento da dose de potássio. A adição de potássio aumentou a concentração de holocelulose nas progênies 1 e 2 . As progênies tiveram comportamentos distintos para a quantidade de holocelulose em função da dose de $\mathrm{K}$ na solução nutritiva, sendo a progênie 3 considerada mais responsiva. 


\title{
EFFECT OF POTASSIUM ON GROWTH, CONCENTRATION OF NUTRIENTS AND ON THE CHARACTERISTICS OF THE JUVENILE WOOD OF Eucalyptus grandis W. Hill ex Maiden PROGENIES GROWN IN NUTRITIVE SOLUTION
}

\author{
Author: Ronaldo Luiz Vaz de Arruda Silveira \\ Adviser: Prof. Dr. Eurípedes Malavolta
}

\section{SUMMARY}

The objective of this study was to evaluate the effects of potassium on growth, concentration of nutrients, total soluble sugars, diamine putrescine and polyamines spermine and spermidine, and physical, chemical and anatomical characteristics of the wood from four Eucalyptus grandis progenies. The efficiency of $\mathrm{K}$ use was also estimated.

The plants were grown during 67 days after the transplanting in nutritious solution with $175,5 \mathrm{mg} \mathrm{K} \mathrm{L}^{-1}$. From then on the plants were given four $\mathrm{K}$ doses $(0 ; 58.5$; 175.5 and $526.5 \mathrm{mg} \mathrm{L}^{-1}$ ). The nutritious solutions were changed fortnightly. Height and diameter were measured monthly. After nine months of plants growth on different $\mathrm{K}$ doses diagnostic leaves were sampled $\left(5^{\text {th }}\right.$ and $6^{\text {th }}$ leaf starting from the apex of the branches) to determine the concentration of total soluble sugars, putrescine, spermidine and spermine. After ten months of plants growth on different $\mathrm{K}$ doses, the plants were harvested and split into new leaves, diagnostic leaves, old leaves, branches, bark and log. Each part of the plant was placed in identified paper packs and dried until constant weight. After grinding of the dry matter the concentrations of $\mathrm{N}, \mathrm{P}, \mathrm{K}, \mathrm{Ca}, \mathrm{Mg}, \mathrm{S}, \mathrm{B}, \mathrm{Cl}$, $\mathrm{Cu}, \mathrm{Fe}, \mathrm{Mn}$ and $\mathrm{Zn}$ were determined. 
Samples of the log were used for accomplished anatomical analyses to quantify the length, width, the diameter of the lumen, thickness and fiber's wall fraction. Chemical analyses were made to determine the holocellulose concentration, extractive and lignin. Basic density of the log in three positions of the stem (apex, half and base) was also determined.

It was conclude under the experimental conditions that the genetic material of $E$. grandis responded differently in log production due to the $\mathrm{K}$ application. The progenies one and four were not responsive and progeny two and three were responsive in function of the increasing in $\mathrm{K}$ doses. The adequate level of $\mathrm{K}$ concentration in the leaves used for diagnosis varied in function of the genetic material. The progenies also presented differentiated behavior as to the $\mathrm{K}$ use for cellulose production. The progeny two was considered the least efficient. The deficiency of $\mathrm{K}$ did to accumulation of putrescine in the leaves of all progenies. In the progenies one and three, the increase of $\mathrm{K}$ doses in the substrate caused decrease in the concentration of sugars in the leaves used for diagnosis. The progenies showed different behavior for the log basic density in function of $\mathrm{K}$ doses variation in the nutrition solution. The largest $\mathrm{K}$ doses caused increase on the length of width and fibers of the genotypes, except the progeny one. In the same progeny, wall thickness decreased with the increase of $\mathrm{K}$ doses. In the progenies two and three, the $\mathrm{K}$ doses in the nutritious solution caused increase of the lumen diameter of the fibers. The fiber's wall fraction was reduced for progenies one, two and three with the increase of $\mathrm{K}$ doses in the nutritious solution. $\mathrm{K}$ addition increased the holocellulose concentration in the progenies one and two. The progenies showed different behaviors for the holocellulose in function of the $\mathrm{K}$ dose in the nutritious solution, progeny three being the more responsive in holocelullose production. 


\section{INTRODUÇÃO}

O gênero Eucalyptus, da família da Myrtaceae, é originário da Austrália e Indonésia, de onde foi introduzido no Brasil devido ao seu alto potencial produtivo em madeira. Com isso, a indústria de base florestal representada pelos importantes setores de papel e celulose, carvão para siderurgia, aglomerados, painéis, postes e dormentes, tem os reflorestamentos com eucalipto como principal fonte de matéria prima.

Pelas estimativas da Associação Nacional de Fabricantes de Papel e Celulose, o Brasil produz 5.700.000 t de celulose ano $^{-1}$, com cerca de $53 \%$ dessa produção destinada ao mercado externo (ANFPC, 1996). Já em relação a madeira sólida para painéis/aglomerados/laminados e serraria, a produção brasileira é de aproximadamente 650.000 e $2.000 .000 \mathrm{~m}^{3}$ ano $^{-1}$, respectivamente. A área reflorestada que abastece esses setores mais os de postes, dormentes e outros produtos é de 4.800.000 ha, sendo que 62\% dessa área é representada pelo gênero Eucalyptus. A cultura do eucalipto ocupa 2.970 .000 ha, sendo que $51 \%$ e $19 \%$ dessa área está concentrada nos estados de Minas Gerais e São Paulo, respectivamente. Segundo previsões da ANFPC (1996) haverá aumento do consumo de produtos florestais brasileiros na ordem de $250 \%$ no ano de 2010 , sendo com isso necessário aumentar a produção florestal brasileira. Vários caminhos podem ser adotados para aumentar a produção florestal como: aumento de rendimento dos processos fabris, da área reflorestada, da produtividade das florestas através da seleção de materiais genéticos mais adaptados e produtivos, de técnicas mais apropriadas de manejo como adubação, controle de plantas daninhas, preparo de solo e outras. 
Neste contexto, a adubação constitui numa das principais práticas para o aumento da produtividade da cultura do Eucalyptus, devido a maioria dos plantios estarem localizados em solos arenosos de baixa fertilidade (Tokeshi et al., 1976; Barros et al., 1981 e 1992; Valeri et al., 1983 e 1991; Stape \& Zani Filho, 1990; Stape et al., 1992; Fonseca et al., 1993; Galo, 1993 e Gava, 1996).

Um dos elementos que mais tem limitado a produtividade do Eucalyptus no Brasil é o potássio. Levantamentos nutricionais realizados na região de Itatinga/SP, Capão Bonito/SP e Lençóis Paulista/SP mostraram que independentemente do material genético, todas as florestas avaliadas apresentavam deficiência de K (Silveira et al., 1998 e 1999). Considerando que essas regiões são caracterizadas por extensos plantios de Eucalyptus spp, com área superior a 250.000 ha, sendo a maior parte constituída por solos arenosos álicos, onde a produtividade é baixa, torna-se necessário a seleção de genótipos que sejam mais eficientes na absorção e utilização de nutrientes, especialmente potássio.

As hipóteses do trabalho foram: o potássio altera as características fisicas, químicas e anatômicas da madeira; as progênies respondem de forma diferenciada a aplicação desse nutriente influenciando o nível de poliamina e açúcares solúveis totais nas folhas; as progênies diferem em relação a eficiência de utilização de potássio; existe diferença entre os materiais genéticos para a concentração de poliaminas, açúcares solúveis totais e parâmetros físicos, químicos e anatômicos da madeira.

Os objetivos do presente estudo foram: determinar os efeitos do potássio e de genótipos de E. grandis sobre o crescimento, na concentração de açúcares solúveis totais, poliaminas e nas características fisicas, químicas e anatômicas da madeira de $E$. grandis e avaliar as progênies quanto a eficiência de utilização de potássio. 


\section{REVISÃO DE LITERATURA}

\subsection{Funções do potássio na planta}

O potássio não faz parte de nenhum composto orgânico, não desempenhando função estrutural na planta. Este macronutriente atua na ativação de aproximadamente 50 enzimas, destacando-se as sintetases, oxiredutases, desidrogenases, transferases, quinases e aldolases (Mengel \& Kirkby, 1978; Marschner, 1995 e Malavolta et al., 1997). O potássio está ainda envolvido na síntese de proteínas, plantas com baixos teores de potássio apresentam redução na síntese, com acúmulo de compostos de baixo peso molecular como aminoácidos, amidas, aminas e nitratos.

O potássio atua no controle osmótico das células. Plantas deficientes em potássio apresentam menor turgor da célula, pequena expansão celular, maior potencial osmótico, abertura e fechamento dos estômatos de forma irregular (Mengel \& Kirkby, 1978 e Malavolta et al., 1997). Outro efeito atribuído ao K é que plantas bem nutridas são mais resistentes a secas e geadas, em razão da maior retenção de água.

O potássio está envolvido também nos mecanismos de defesa das plantas a pragas e doenças. As plantas bem nutridas em potássio apresentam redução na incidência, severidade e danos causados por insetos e fungos. A explicação seria que altas concentrações de $\mathrm{K}$ nos tecidos favorecem a síntese e o acúmulo de compostos fenólicos, os quais atuam como inibidores de insetos e fungos (Huber \& Amy, 1985, Perrenoud, 1990). Outra explicação seria que plantas deficientes apresentam tecidos menos enrijecidos, como consequência da menor espessura da cutícula e da parede celular, menor formação de tecidos esclerenquimatosos, menor lignificação e suberização (Ellet, 1973; Perrenoud, 1990). Além disso, na deficiência de potássio ocorre menor síntese de compostos de alto peso molecular (proteína, amido e celulose), 
favorecendo o acúmulo de compostos de baixo peso molecular (açúcares solúveis, aminoácidos e $\mathrm{N}$ solúvel) como resultado do aumento da atividade de enzimas decompositoras (amilase, sacarase, glucosidase e protease). $\mathrm{O}$ acúmulo desses compostos altera o equilíbrio osmótico das células e sua concentração é aumentada nos exsudados liberados pelas plantas, favorecendo o desenvolvimento de pragas e doenças.

As plantas bem nutridas em potássio apresentam maior síntese de material para a formação da parede celular. Frequentemente, as paredes são mais espessas devido a maior deposição de celulose e compostos relativos, promovendo maior estabilidade e um aumento da resistência das plantas ao acamamento e as infestações de doenças e pragas (Pretty, 1982; Beringer \& Nothdurft, 1985).

$\mathrm{O}$ potássio está envolvido na fotossíntese. Na carência de $\mathrm{K}$, verifica-se redução na taxa fotossíntética por unidade de área foliar, e também maiores taxas de respiração. A combinação desses fatores pode reduzir as reservas de carboidratos da planta (Pretty, 1982). Um suprimento inadequado de potássio também faz com que os estômatos não se abram regularmente, podendo ocorrer menor assimilação de $\mathrm{CO}_{2}$ nos cloroplastos, diminuindo consequentemente a taxa fotossintética.

O potássio atua no metabolismo (ativação da sintetase do amido, sintetase fosfato sacarose e outras enzimas) e transporte de carboidratos (Mengel \& Kirkby, 1978; Malavolta, 1980; Marschner, 1995; Malavolta et al., 1997). Normalmente, plantas deficientes em potássio apresentam acúmulo de açúcares hexoses e decréscimo de carboidratos de maior cadeia como amido e sacarose nas folhas (Evans \& Sorger, 1966 citado por Huber, 1985), como consequência da menor atividade da sintetase fosfato sacarose. Segundo Marschner (1995), existe relação inversa entre a concentração de potássio e o conteúdo de açúcares nos tecidos.

O potássio assume papel importante no transporte da sacarose e dos fotossintetizados das folhas para os órgãos de armazenamento. Durante este caminho, os produtos assimilados passam por três sistemas: a) difusão no simplasto e espaço livre; b) transporte ativo através da membrana citoplasmática para o floema; c) fluxo passivo pelos tubos crivosos. O potássio influencia os três processos, em particular os dois últimos (Header, 1977 citado por Malavolta \& Crocomo, 1982). Em relação ao último 
processo, Marschner (1995) relata que a função do potássio é manter o pH alto nos tubos crivosos, facilitando assim o transporte da sacarose. Portanto, um suprimento adequado de potássio aumenta a síntese de carboidratos em razão da maior taxa fotossintética, bem como, a eficiência de translocação desses compostos.

\subsection{Sintomas de deficiência de potássio}

O potássio tem alta redistribuição nos tecidos, portanto, os sintomas de carência surgem nas folhas mais velhas (Malavolta et al., 1997). No estádio inicial da deficiência, aparecem manchas cloróticas, nos espaços entre as nervuras e espalhadas irregularmente por toda a superficie foliar. Com a evolução dos sintomas, as manchas se unem formando faixas cloróticas ou avermelhadas nas margens das folhas velhas, com posterior necrose dos tecidos (Will, 1961; Kaul et al., 1966, 1968, 1970a e 1970b; Rocha Filho et al., 1978; Dell et al., 1995; Silveira et al.,1996 e 1999). No estádio mais avançado, a presença de clorose e necrose ocorrem até nas folhas mais jovens, enquanto que as folhas velhas enrolam e secam (Figura 1A). As plantas também podem apresentar aumento das brotações laterais com a paralização do desenvolvimento vegetativo conforme verificado por Kaul et al. (1966) e Rocha Filho et al. (1978).

A Figura 1 A-E, mostra os sintomas de deficiência de potássio em algumas espécies de Eucalyptus.

\subsection{Soluções nutritivas usadas no cultivo de Eucalyptus}

Os estudos visando determinar as doses adequadas de macro e micronutrientes em solução nutritiva para o crescimento do Eucalyptus são raros, normalmente os experimentos nessa condição tem utilizado a solução de Hoagland \& Arnon (1950). No entanto, Cromer et al. (1984) estudaram o efeito de diferentes proporções da solução de Hoagland \& Amon/água destilada (1:4999; 1:499, 1:49, 1:4 e 1:0) no crescimento de E. delegatensis, E. maculata e E. brockwayi. Observaram que para E. delegatensis não houve diferença entre as proporções de 1:4 e 1:0, o contrário foi 
verificado para E. maculata e E. brockwayi, os quais apresentaram maior produção de matéria seca quando as plantas foram cultivadas na solução com proporção de 1:0.

A

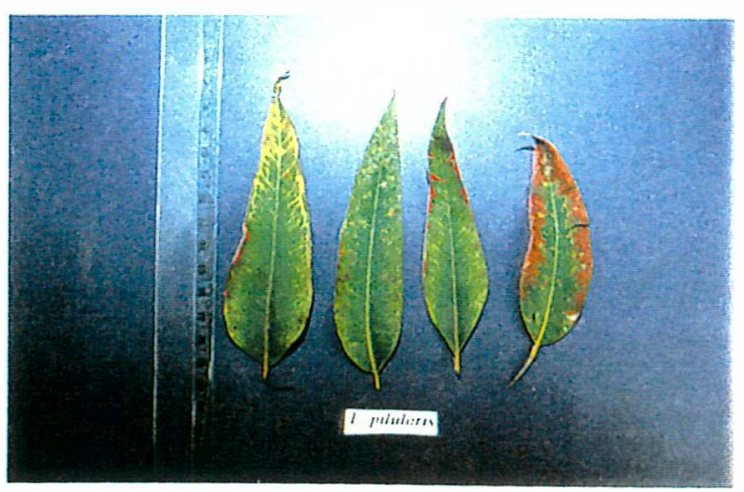

$\mathrm{C}$

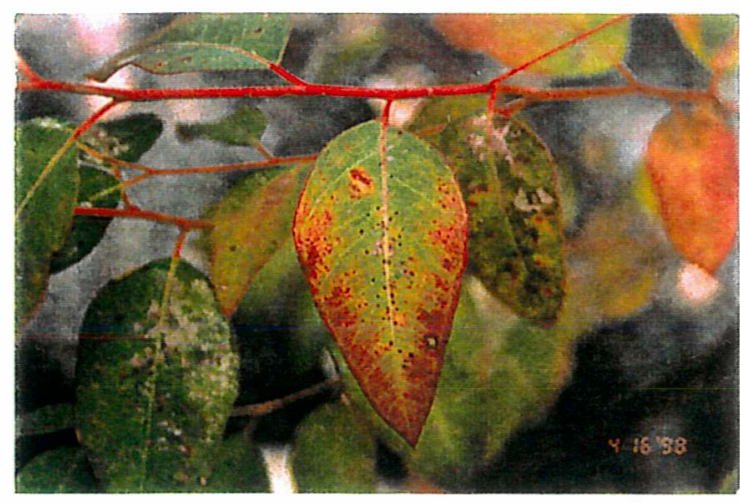

$\mathrm{B}$

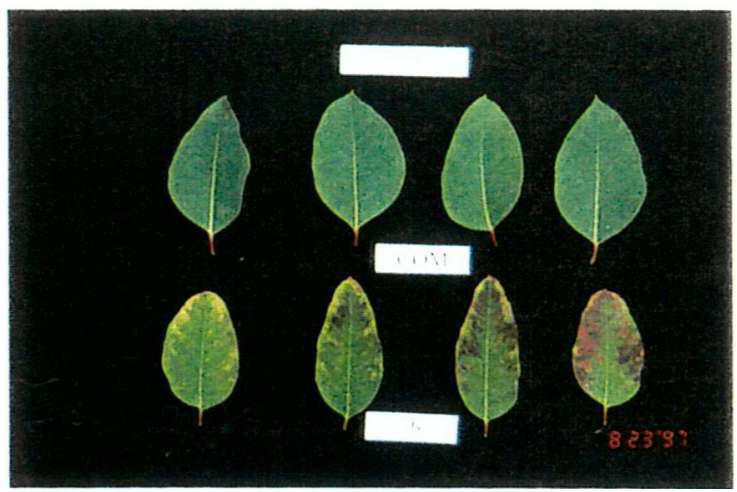

D

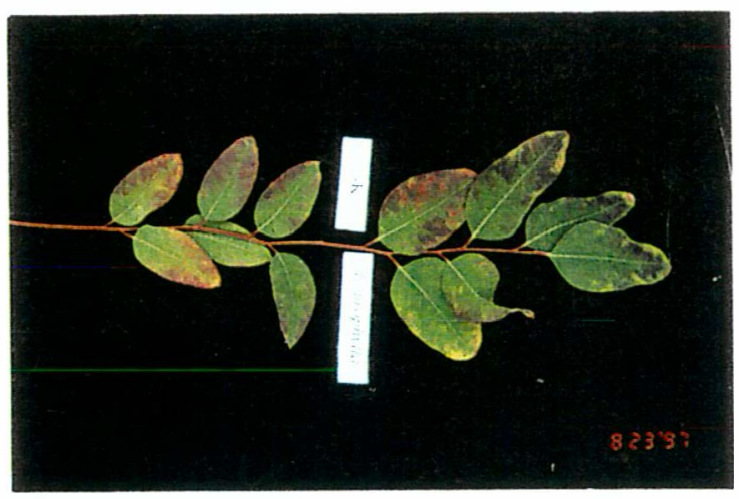

E

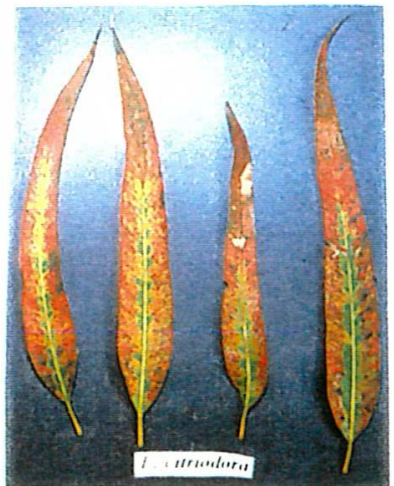

Figura 1. Sintomas de deficiência de potássio em cspécies de Eucalyptus. A - Folhas de E. pilularis com clorose e necrose nas margens; B - Folhas de E. urophylla com clorose e avermelhamento marginal comparadas com folhas sem sintomas; C - Folhas de E. grandis com avermelhamento marginal; D - Progressão dos sintomas foliares $\mathrm{em}$ E .urophylla conforme posição das folhas nos ramos, E - Folhas de E. citriodora com avermelhamento e necrose marginal. A e E - fotografias tiradas no arboreto da Faculdade de Agronomia da Unesp, Botucatu (Silveira et al., 1999). 


\subsection{Exigências nutricionais do Eucalyptus em relação a potássio}

\subsubsection{Conteúdo e eficiência de utilização de potássio}

Os plantios de Eucalyptus concentram-se normalmente em solos de baixa fertilidade (Tabela 1). A quantidade de potássio disponível nos primeiros $20 \mathrm{~cm}(31 \mathrm{~kg}$ $\mathrm{ha}^{-1}$ ) da maioria dos solos florestais é insuficiente para atender uma demanda média de $\mathrm{K}$ pelo Eucalyptus com idade aproximadamente de 8 anos (261 $\left.\mathrm{kg} \mathrm{ha}^{-1}\right)$, conforme mostra a Tabela 3. Além disso, a eficiência da adubação potássica nesses solos é baixa, uma vez que apresentam significativa lixiviação, em razão de serem altamente intemperizados e de textura arenosa, com baixa CTC.

Tabela 1. Características químicas de alguns solos florestais na profundidade de $0-20 \mathrm{~cm}$, no Estado de São Paulo.

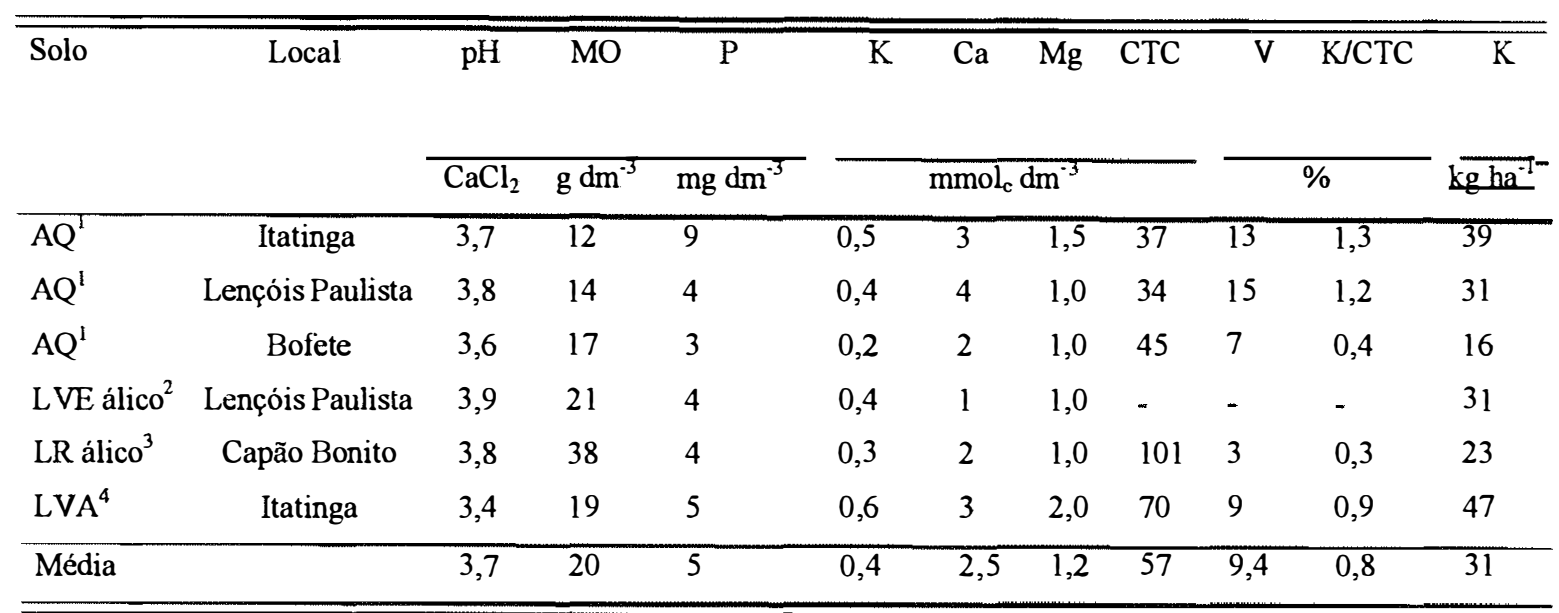

1 - areia quartzosa com teor de areia variando de 93 a $98 \%: 2$ - Latossolo vermelho escuro; 3 - Latossolo roxo; 4 - Latossolo vermelho amarelo.

Fonte: Silveira et al., 1995c.

A Tabela 2 mostra o conteúdo de potássio, a produção de matéria seca total e a eficiência de utilização de potássio em mudas de E. grandis. Em relação a eficiência nutricional, nota-se que Camargo (1997) encontrou diferença significativa entre os clones de E. grandis, sendo que o mais eficiente apresentou uma conversão de $114,7 \mathrm{mg}$ de MS para cada mg de $\mathrm{K}$, enquanto o menos eficiente, $87,7 \mathrm{mg}$ de MS por $\mathrm{mg}$ de $\mathrm{K}$. 
Tabela 2. Produção de matéria seca total, conteúdo e eficiência de utilização de potássio em mudas de Eucalyptus grandis.

\begin{tabular}{|c|c|c|c|c|c|c|c|c|c|}
\hline \multirow[t]{2}{*}{ E. grandis } & \multirow{2}{*}{$\begin{array}{l}\text { Idade } \\
\text { (dias) }\end{array}$} & \multirow[t]{2}{*}{ Local } & \multicolumn{4}{|c|}{$\begin{array}{l}\mathrm{K} \text { na planta } \\
\mathrm{mg} / \text { planta }\end{array}$} & \multirow[t]{2}{*}{$\begin{array}{l}\text { MST }^{\mathrm{T}} \\
\text { g/planta }\end{array}$} & \multirow{2}{*}{$\begin{array}{c}\mathrm{EKT}^{2} \\
\mathrm{mg} \mathrm{MST} \\
\mathrm{mg}^{-1} \mathrm{de} \\
\mathrm{K}\end{array}$} & \multirow[t]{2}{*}{ Referência } \\
\hline & & & Folhas & Caule & Raizes & $\overline{\text { Total }}$ & & & \\
\hline $\begin{array}{l}\text { Clone - Procedência } \\
\text { Chisengu }^{3}\end{array}$ & 62 & $\begin{array}{l}\text { casa-de- } \\
\text { vegetação }\end{array}$ & $\begin{array}{l}88,1 \\
(56)^{4}\end{array}$ & $\begin{array}{l}30,9 \\
(19)\end{array}$ & $\begin{array}{l}39,4 \\
(25)\end{array}$ & 158,4 & 11,4 & 72,0 & Souza (1994) \\
\hline $\begin{array}{l}\text { Clone - Procedência } \\
\text { Mechece }^{3}\end{array}$ & 62 & $\begin{array}{l}\text { casa-de- } \\
\text { vegetação }\end{array}$ & $\begin{array}{l}92,9 \\
(54)\end{array}$ & $\begin{array}{l}38,2 \\
(22)\end{array}$ & $\begin{array}{l}41,6 \\
(24)\end{array}$ & 172,7 & 13,7 & 79,3 & Souza (1994) \\
\hline $\begin{array}{l}\text { Clone - Procedência } \\
\text { Penhalonga }^{3}\end{array}$ & 62 & $\begin{array}{l}\text { casa-de- } \\
\text { vegetação }\end{array}$ & $\begin{array}{l}94,9 \\
(49)\end{array}$ & $\begin{array}{l}46,9 \\
(24)\end{array}$ & $\begin{array}{l}52,6 \\
(27)\end{array}$ & 194,4 & 14,7 & 75,6 & Souza (1994) \\
\hline $\begin{array}{l}\text { Clone - Procedência } \\
\text { Tilbury }^{3}\end{array}$ & 62 & $\begin{array}{l}\text { casa-de- } \\
\text { vegetação }\end{array}$ & $\begin{array}{l}109,1 \\
(60)\end{array}$ & $\begin{array}{l}39,6 \\
(22)\end{array}$ & $\begin{array}{l}33,7 \\
(18)\end{array}$ & 182,4 & 13,9 & 76,2 & Souza (1994) \\
\hline $\begin{array}{l}\text { Semente Procedência } \\
\text { Bofete }\end{array}$ & 97 & viveiro & $\begin{array}{l}7,0 \\
(47)\end{array}$ & $\begin{array}{l}5,0 \\
(33)\end{array}$ & $\begin{array}{l}3,0 \\
(20)\end{array}$ & 15,0 & 2,1 & 140,0 & $\begin{array}{l}\text { Silveira } \\
\text { et al. (1995a) }\end{array}$ \\
\hline Clone A7 & 90 & viveiro & $\begin{array}{l}3,4 \\
(45)\end{array}$ & $\begin{array}{l}2,9 \\
(39)\end{array}$ & $\begin{array}{l}1,2 \\
(16)\end{array}$ & 7,5 & 0,86 & 114,7 & $\begin{array}{l}\text { Camargo } \\
(1997)\end{array}$ \\
\hline Clone C4 & 90 & viveiro & $\begin{array}{l}3,7 \\
(38)\end{array}$ & $\begin{array}{l}4,3 \\
(44)\end{array}$ & $\begin{array}{l}1,7 \\
(18)\end{array}$ & 9,7 & 0,88 & 90,7 & $\begin{array}{l}\text { Camargo } \\
\text { (1997) }\end{array}$ \\
\hline Clone D19 & 90 & viveiro & $\begin{array}{l}4,1 \\
(42)\end{array}$ & $\begin{array}{l}4,1 \\
(42)\end{array}$ & $\begin{array}{l}1,6 \\
(16)\end{array}$ & 9,8 & 0,86 & 87,7 & $\begin{array}{l}\text { Camargo } \\
(1997)\end{array}$ \\
\hline Clone F40 & 90 & viveiro & $\begin{array}{l}3,7 \\
(52)\end{array}$ & $\begin{array}{l}2,5 \\
(35)\end{array}$ & $\begin{array}{l}0,9 \\
(13)\end{array}$ & 7,1 & 0,66 & 92,9 & $\begin{array}{l}\text { Camargo } \\
\text { (1997) }\end{array}$ \\
\hline
\end{tabular}

1- matéria seca total: 2 - eficiència de utilização de potássio; 3 - média de vários clones; 4 - percentual em relação ao conteúdo total de potássio.

Vários trabalhos mostram o conteúdo de potássio nas diferentes partes das plantas de várias espécies de Eucalyptus (Tabela 3). Nota-se uma grande variação do conteúdo em função da espécie, idade, fertilidade do solo, produtividade e local. Os valores médios mostraram que cerca de $24 \%$ do conteúdo total encontra-se nas folhas, $16 \%$ nos ramos, $20 \%$ na casca e $40 \%$ na madeira.

A eficiência de utilização de nutrientes é o quociente entre a matéria seca e o conteúdo de determinado nutriente na planta. Este indice é resultado da evolução das espécies frente a ambientes distintos. Barros et al. (1985) verificaram que não existe 
necessariamente uma relação direta entre a produção de biomassa e a eficiência de utilização dos nutrientes

Cada material genético tem habilidade diferenciada de uso de um ou de outro nutriente absorvido. Além disso, considerando a vasta diversidade ambiental encontrada na região de origem das espécies de Eucalyptus (Barros et al., 1990), esperase que ocorra grande diferenciação quanto a eficiência de absorção e utilização dos nutrientes pelos materiais genéticos de Eucalyptus. Neste sentido, Souza (1994) constatou diferença significativas entre 15 clones de $E$. grandis plantados na região de Quartel Geral/MG, sendo que as variações foram de 541 a $937 \mathrm{~kg}$ de MS de tronco produzida para cada $\mathrm{kg}$ de $\mathrm{K}$ absorvido. Teixeira et al. (1989) também constataram maior eficiência do E. saligna em relação ao E. citriodora para o uso do potássio, ou seja, $1715 \mathrm{~kg}$ de madeira para cada $\mathrm{kg}$ de $\mathrm{K}$ contra $1072 \mathrm{~kg}$ de madeira produzida para cada $\mathrm{kg}$ de $\mathrm{K}$, respectivamente. Notaram ainda que o $E$ saligna foi muito mais eficiente na utilização de Ca e Mg (2575 kg de madeira para cada kg de Ca absorvido e $7500 \mathrm{~kg}$ de madeira para cada $\mathrm{kg}$ de $\mathrm{Mg}$ absorvido) para a produção de madeira quando comparado ao E. citriodora (478 kg de madeira para cada $\mathrm{kg}$ de Ca absorvido e $3374 \mathrm{~kg}$ de madeira para cada $\mathrm{kg}$ de $\mathrm{Mg}$ absorvido).

Leite et al. (1998) observaram que E. grandis com 31 meses de idade, na região de Santa Bárbara/MG, apresentava uma produção de $552 \mathrm{~kg}$ de MS de tronco para cada kg de potássio contido na planta. Para idades mais avançadas (9 anos), Pereira et al. (1984) encontraram valores de eficiência de utilização de $\mathrm{K}$ mais altos que os obtidos por Leite et al. (1998), $1667 \mathrm{~kg}$ de tronco para cada kg de K em E. saligna e $1005 \mathrm{~kg}$ de tronco para cada $\mathrm{kg}$ de $\mathrm{K}$ em E. citriodora. Resultados similares foram verificados por Galo (1993), sendo que o valor para a eficiência de utilização de potássio para $E$. grandis aos 78 meses de idade, na região de Itamarandiba/MG, foi de $1300 \mathrm{~kg}$ de tronco para cada $\mathrm{kg}$ de $\mathrm{K}$ absorvido. 
Tabela 3. Produtividade de florestas de Eucalyptus e o conteúdo de potássio.

\begin{tabular}{|c|c|c|c|c|c|c|c|c|c|c|c|}
\hline \multirow{4}{*}{ Espécie } & \multirow{4}{*}{$\begin{array}{l}\text { Idade } \\
\text { (anos) }\end{array}$} & \multirow{4}{*}{ Local } & \multicolumn{6}{|c|}{ K na planta } & \multicolumn{2}{|c|}{ Produtividade } & \multirow[t]{3}{*}{ Fonte } \\
\hline & & & \multirow[t]{3}{*}{ Folhas } & \multirow[t]{3}{*}{ Ramos } & \multicolumn{3}{|c|}{ Caule } & \multirow[t]{3}{*}{ Total } & \multirow{3}{*}{$\begin{array}{l}\text { MS } \\
\mathrm{tha}^{-1}\end{array}$} & \multirow{3}{*}{$\begin{array}{l}\text { Volume } \\
\frac{\mathrm{m}^{3} \mathrm{ha}^{-1}}{}\end{array}$} & \\
\hline & & & & & Casca & Madeira & $C+M$ & & & & \\
\hline & & & & & \multicolumn{2}{|c|}{$\mathrm{kg} \mathrm{ha}^{-1}$} & & & & & \\
\hline \multirow[t]{2}{*}{ E. grandis } & 6 & Carbonita/MG & 7 & 4 & 10 & 11 & 21 & 32 & 33 & - & Reis \\
\hline & & & $(22)^{*}$ & (12) & (31) & (34) & (66) & & & & et al. (1987) \\
\hline \multirow[t]{2}{*}{ E grandis } & 6 & Bom & 35 & 38 & 66 & 51 & 117 & 190 & 85 & - & Reis \\
\hline & & Despacho/MG & (19) & (20) & (35) & (27) & (61) & & & & et al. (1987) \\
\hline \multirow[t]{2}{*}{ E. grandis } & 6 & Mogi & 28 & 23 & - & - & 194 & 245 & 249 & - & Belotte \\
\hline & & Guaçu/SP & (11) & (9) & & & (79) & & & & et al. (1979) \\
\hline \multirow[t]{2}{*}{ E. grandis } & 20 & Austrália & 108 & 103 & 92 & 271 & 363 & 574 & - & - & Judd \\
\hline & & & (19) & (28) & (16) & (47) & (63) & & & & (1996) \\
\hline \multirow[t]{2}{*}{ E. fastigata } & 4 & Nova & 96 & 48 & 26 & 77 & 103 & 246 & 62 & - & Madgwick \\
\hline & & Zelândia & (39) & (19) & (11) & (31) & $(42)$ & & & & et al. (1981) \\
\hline \multirow[t]{2}{*}{ E. nitens } & 4 & Nova & 82 & 53 & 52 & 120 & 172 & 306 & 82 & - & Madgwick \\
\hline & & Zelândia & (27) & (17) & (17) & (39) & $(56)$ & & & & et al. (1981) \\
\hline \multirow[t]{2}{*}{ E. saligna } & 8 & Austrália & 54 & 50 & 62 & 137 & 199 & 303 & 130 & 211 & Frederick \\
\hline & & & (18) & (16) & $(20)$ & $(45)$ & $(66)$ & & & & et al. (1985) \\
\hline \multirow[t]{2}{*}{ E. saligna } & 9 & Curvelo/MG & 28 & 23 & 29 & 61 & 90 & 141 & - & 289 & Pereira \\
\hline & & & (20) & (16) & (21) & (43) & (64) & & & & et al. (1984) \\
\hline \multirow[t]{2}{*}{ E.citriodora } & 9 & Curvelo/MG & 141 & 25 & 78 & 102 & 165 & 335 & - & 195 & Pereira \\
\hline & & & $(42)$ & (7) & (23) & (27) & $(51)$ & & & & et al. (1994) \\
\hline \multirow[t]{2}{*}{ Média } & 8 & & 64 & 41 & 52 & 104 & 156 & 261 & & - & - \\
\hline & & & (24) & (16) & $(20)$ & (40) & $(60)$ & & & & \\
\hline
\end{tabular}

* - entre parênteses estão os valores percentuais em relação ao total.

Silva et al. (1983) estudando a eficiência de utilização de K em 5 espécies de Eucalyptus, verificaram que o E. grandis foi a espécie mais eficiente, seguida em ordem decrescente pelo E. saligna, E. dunnii, E. propinqua e E. robusta. Poggiani et al. (1984) também verificaram que o E. grandis era menos exigente e o mais eficiente no uso de nutrientes quando comparado com E. saligna e E. urophylla.

Morais et al. (1990) encontraram variações na produção de MS e na extração de nutrientes pelo E. grandis com oito anos de idade em duas regiões bioclimáticas estudadas. Verificaram que na região de Viçosa/MG houve maior produção de $\mathrm{MS}$, bem como, a extração de nutrientes quando comparada a região de Paraopeba/MG, isto ocorreu devido as condições edafoclimáticas de Viçosa assemelharem-se mais as do 
local de origem dessa espécie, ou seja, maior disponibilidade de água e nutrientes quando comparadas as de Paraopeba. As extrações totais de nutrientes em kg ha ${ }^{-1}$ para Viçosa e Paraopeba foram, respectivamente: 1.313 de N e 458 de N; 56 de P e 30 de P; 753 de K e 208 de K; 775 de Ca e 309 de Ca; 344 de Mg e 81 de $\mathrm{Mg}$. Nota-se que o potássio foi o terceiro nutriente em quantidade extraída, ficando abaixo do nitrogênio e do cálcio. Resultados semelhantes foram obtidos por Bellote (1979) para E. grandis aos 6 anos de idade, na região de Mogi Guaçu/SP, verificando que o $\mathrm{K}$ foi também o terceiro nutriente em quantidade extraída. A quantidade de nutriente em $\mathrm{kg} \mathrm{ha}^{-1}$ contida na parte aérea foi de 473 de N, 32 de P, 245 de K, 555 de Ca, 126 de Mg e 159 de S. Neste estudo, a quantidade percentual de $\mathrm{N}, \mathrm{P}, \mathrm{K}, \mathrm{Ca}, \mathrm{Mg}$ e $\mathrm{S}$ presentes no caule (lenho + casca) em relação ao total foi de $73,73,79,72,84$ e 86, respectivamente. Em outro estudo, nas regiões de Carbonita e Bom Despacho, a extração de potássio pelo $E$. grandis foi inferior somente a de nitrogênio. Para a região mais produtiva (Bom Despacho), a quantidade de $\mathrm{N}, \mathrm{P}, \mathrm{K}, \mathrm{Ca}$ e $\mathrm{Mg}$ alocada na parte aérea em $\mathrm{kg} \mathrm{ha}^{-1}$ foi de $323,24,190,150$ e 44 , respectivamente. A percentagem dos nutrientes presentes na madeira em relação ao total foi de: 46 para N; 27 para $\mathrm{P} ; 26$ para K; 19 para Ca e 25 para Mg (Reis et al., 1987).

Um dos poucos trabalhos em relação a quantidade extraída de micronutrientes pelo E. grandis foi realizado por Bellote (1979). Este autor verificou que a quantidade contida na parte aérea e no caule em $\mathrm{kg} \mathrm{ha}^{-1}$ foi de: $1,5 \mathrm{de} \mathrm{B}, 1,3 \mathrm{de} \mathrm{B}$; 0,9 de $\mathrm{Cu}, 0,8 \mathrm{de} \mathrm{Cu} ; 5,4$ de Fe, 3,9 de Fe, 18,9 de Mn, 15,3 de Mn; 0,5 de Zn e 0,4 kg de $\mathrm{Zn}$, respectivamente.

\subsubsection{Concentração de potássio e outros nutrientes nas partes da planta}

Haag et al. (1976) estudaram a composição mineral das folhas de 5 espécies de Eucalyptus na condição de campo, e encontraram diferenças na concentração dos nutrientes, principalmente, para os macronutrientes. De maneira geral, as maiores concentrações foram observadas no E. grandis quando comparada com as outras espécies. Em relação ao potássio, houveram variações significativas, as quais obedeceram a seguinte ordem decrescente de concentração nas folhas: E. grandis $(21,2 \mathrm{~g}$ 
$\left.\mathrm{kg}^{-1}\right)>$ E. saligna $\left(17,7 \mathrm{~g} \mathrm{~kg}^{-1}\right)>$ E. robusta $\left(15,1 \mathrm{~g} \mathrm{~kg}^{-1}\right)=$ E. microcorys $\left(14,6 \mathrm{~g} \mathrm{~kg}^{-1}\right)=$ E. resinifera $\left(14,1 \mathrm{~g} \mathrm{~kg}^{-1}\right)$. Porém, no estudo realizado por Silva et al. (1983), não houve efeito significativo das espécies de Eucalyptus sobre as concentrações foliares de potássio. As concentrações de potássio encontradas nas diversas espécies foram inferiores as obtidas por Haag et al. (1976). As concentrações de potássio em $\mathrm{g} \mathrm{kg}^{-1}$ foram de 8,38, 8,34, 8,32, 8,29 e 7,4 para E. robusta, E. grandis, E. saligna, E. propinqua e E. dunnii, respectivamente. Ao contrário das folhas, verificaram-se diferenças entre os materiais genéticos para a concentração de potássio nos ramos, casca e lenho. Nos ramos, as concentrações variaram de $1,8 \mathrm{~g} \mathrm{~kg}^{-1}$ (E. robusta) a $3,2 \mathrm{~g} \mathrm{~kg}^{-1}$ (E. propinqua), enquanto que na casca e lenho, $4,1 \mathrm{~g} \mathrm{~kg}^{-1}$ (E. dunnii) a $2,2 \mathrm{~g} \mathrm{~kg}^{-1}$ (E. propinqua) e $1,3 \mathrm{~g} \mathrm{~kg}^{-1}$ (E. propinqua) a $0,6 \mathrm{~g} \mathrm{~kg}^{-1}$ (E. grandis), respectivamente. Ao comparar as espécies em relação a concentração de potássio, observaram que o $E$. propinqua apresentava maior concentração nos ramos e no lenho e menor na casca em relação as demais espécies.

Judd (1996) relata as concentrações médias de N, P, K, Ca e Mg em g kg${ }^{-1}$ nas partes da planta de espécies de Eucalyptus pertencentes ao sub-gênero Symphyomyrtus. Para o N, 17,5 nas folhas, 4,0 nos ramos, 3,5 na casca e 1,2 no lenho; para o $\mathrm{P}, 1,2$ nas folhas, 0,4 nos ramos e na casca e 0,05 no lenho; para o $K, 7,0$ nas folhas, 3,5 nos ramos, 3,2 na casca e 1,2 no lenho; para o $\mathrm{Ca}, 7,0$ nas folhas, 7,5 nos ramos, 24,0 na casca, 1,0 no lenho; para o $\mathrm{Mg}, 3,0$ nas folhas, 1,5 nos ramos, 1,9 na casca e 0,3 no lenho. Leite et al. (1998) encontraram as seguintes concentrações de N, P, $\mathrm{K}, \mathrm{Ca}$ e $\mathrm{Mg}$ em g kg${ }^{-1}$ nos órgãos de E. grandis com 31 meses de idade: para o N, 19,2 nas folhas, 2,4 na casca, 3,4 nos ramos e 0,7 no lenho; para o $\mathrm{P}, 1,1$ nas folhas, 0,3 nos ramos, 0,4 na casca, 0,1 no lenho; para o $\mathrm{K}, 7,5$ nas folhas, 2,5 nos ramos, 5,8 na casca e 1,4 no lenho; para o $\mathrm{Ca}, 4,4$ nas folhas, 3,0 nos ramos, 8,6 na casca e 0,7 no lenho; para o Mg, 1,9 nas folhas, 0,4 nos ramos, 1,6 na casca e 0,2 no lenho.

Kaul et al. (1968) verificaram em E. grandis com aproximadamente 8 meses de idade, concentrações de potássio nas folhas de 8,0 e 4,0 $\mathrm{g} \mathrm{kg}^{-1}$ quando cultivado na presença e ausência de $\mathrm{K}$ na solução nutritiva. Em estudo similar, com E. globulus, os valores foram de 10,5 e 4,7 $\mathrm{g} \mathrm{kg}^{-1}$, respectivamente (Kaul et al., 1970a). 


\subsubsection{Faixas adequadas e deficientes dos nutrientes}

Malavolta et al. (1997) citam os teores de macro $\left(\mathrm{g} \mathrm{kg}^{-1}\right)$ e micronutrientes $\left(\mathrm{mg} \mathrm{kg}^{-1}\right)$ associados a altas produtividades de $E$. grandis: $\mathrm{N}=21$ a $23 ; \mathrm{P}=1,3$ a 1,$4 ; \mathrm{K}$ $=9$ a $10 ; \mathrm{Ca}=5$ a $6 ; \mathrm{Mg}=2,5$ a $3 ; \mathrm{S}=1,5$ a 2,$5 ; \mathrm{B}=25$ a $30 ; \mathrm{Cu}=7$ a $10 ; \mathrm{Fe}=100$ a $140 ; \mathrm{Mn}=300$ a 400 e $\mathrm{Zn}=12$ a 17 .

As faixas adequadas e deficientes dos macro e micronutrientes nas folhas de Eucalyptus de acordo com vários autores são apresentadas na Tabela 4.

A Tabela 5 apresenta a faixa deficiente e adequada de potássio nas folhas de várias espécies de Eucalyptus no estádio adulto e juvenil. Nota-se que existe grande variação na concentração adequada de potássio em função do material genético. Por exemplo, para o E. grandis na fase juvenil, segundo Novais et al. (1980), a faixa adequada estava compreendida entre 3,3 e $8,1 \mathrm{~g}$ de $\mathrm{K} \mathrm{kg}^{-1}$, enquanto que para $E$. urophylla, de 15 a $18 \mathrm{~g}^{\mathrm{de} \mathrm{K} \mathrm{kg}} \mathrm{kg}^{-1}$ conforme Dell et al. (1995).

Bellote (1990) encontrou em E. grandis cultivado no cerrado de São Paulo, correlações significativas entre potássio no solo e nas folhas e entre estes e a altura das plantas. Silveira et al. (1999) também verificaram relação linear entre a concentração foliar de $\mathrm{K}$ e o volume de madeira para $E$. grandis com 2 anos de idade, na região de Capão Bonito/SP.

Bellotte \& Ferreira (1993) realizaram levantamento do estado nutricional e da fertilidade do solo em plantios de E. grandis aos 3 anos de idade, em 5 locais do estado de São Paulo (Mogi-Guaçu, Casa Branca, Itirapina, Itatinga e Angatuba) e constataram correlações positivas entre o teor de $\mathrm{K}$ e $\mathrm{Mg}$ nas folhas com a altura das plantas. Consideraram ainda que árvores com concentrações de 2,6 a 3,2 g de $\mathrm{Mg} \mathrm{kg}^{-1}$ e maior ou igual a 7,5 $\mathrm{g}$ de $\mathrm{K} \mathrm{kg}^{-1}$, estavam adequadamente nutridas desses elementos. Silveira et al. (1995d) também constataram que o potássio juntamente com o boro foram os nutrientes mais limitantes ao crescimento de $E$. grandis na região de Itatinga/SP.

Herbert (1996) encontrou que a relação foliar N/K e K/P nas folhas considerada ótima para o crescimento do E. grandis foi de 3,5 e 5, respectivamente. Silveira et al. (1999) também citam que as maiores produtividades de E. grandis (75 a 


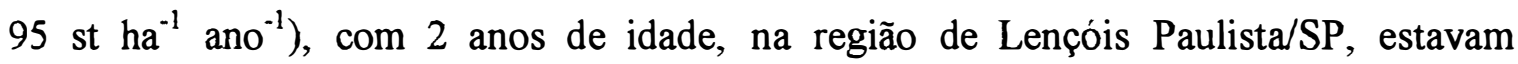
associadas a razões foliares de $\mathrm{K} / \mathrm{Ca}$ na faixa de 1,3 a 1,8 , sendo que para relações menores que 1,0 , ocorriam quedas significativas na produtividade.

Tabela 4. Interpretação dos dados de análise de folhas para o Eucalyptus.

\begin{tabular}{|c|c|c|c|c|c|c|c|}
\hline \multirow[b]{2}{*}{ Elementos } & \multicolumn{4}{|c|}{ Faixa adequada } & \multicolumn{3}{|c|}{ Faixa deficiente } \\
\hline & $\begin{array}{l}\text { Boardman } \\
\text { et al. }(1997)^{1}\end{array}$ & $\begin{array}{c}\text { Dell } \\
\text { et al. }(1995)^{1}\end{array}$ & $\begin{array}{c}\text { Gonçalves } \\
(1995)^{2}\end{array}$ & $\begin{array}{c}\text { Silveira } \\
\text { et al. }(1999)^{1}\end{array}$ & $\begin{array}{c}\text { Malavolta } \\
(1987)^{2}\end{array}$ & $\begin{array}{l}\text { Boardman } \\
\text { et al. }(1997)^{3}\end{array}$ & $\begin{array}{c}\text { Silveira } \\
\text { et al. (1999) }\end{array}$ \\
\hline & \multicolumn{7}{|c|}{$\mathrm{g} \mathrm{kg}^{-1}$} \\
\hline $\bar{N}$ & $16-29$ & $18-34$ & $13,5-18$ & $22-27$ & $8-13$ & $<15$ & $<16$ \\
\hline $\mathrm{P}$ & $1-3$ & $1,0-2,2$ & $0,9-1,3$ & $1,7-2,2$ & $0,4-0,8$ & $<0,7$ & $<1,1$ \\
\hline $\mathrm{K}$ & $6-18$ & $9-18$ & $9-13$ & $8,5-9,0$ & $6-8$ & $<5$ & $<7,0$ \\
\hline $\mathrm{Ca}$ & $2-4$ & $3-6$ & $6-10$ & $7,1-11$ & $2-4$ & $<1$ & $<5,5$ \\
\hline $\mathrm{Mg}$ & $1-3$ & $1,1-2,1$ & $3,5-5$ & $2,5-2,8$ & $1,5-2,0$ & $<0,6$ & $<2,1$ \\
\hline \multirow[t]{2}{*}{$\mathrm{S}$} & $1,5-2,0$ & $1,5-2,3$ & $1,5-2$ & $1,5-2,1$ & $0,8-1,2$ & $<1$ & $<1,3$ \\
\hline & \multicolumn{7}{|c|}{$\mathrm{mg} \mathrm{kg}^{-1}$} \\
\hline$\overline{\mathrm{B}}$ & $15-100$ & $15-27$ & $30-50$ & $34-44$ & $15-20$ & $<8$ & $<21$ \\
\hline $\mathrm{Cu}$ & $4-12$ & $2-7,4$ & $7-10$ & $6-7$ & $4-6$ & $<2$ & $<4$ \\
\hline $\mathrm{Fe}$ & $50-156$ & $63-128$ & $150-200$ & $65-125$ & $75-100$ & - & - \\
\hline $\mathrm{Mn}$ & $190-700$ & $193-547$ & $400-600$ & $200-840$ & $<100$ & - & - \\
\hline $\mathrm{Zn}$ & $15-46$ & $17-42$ & $35-50$ & $15-20$ & $20-30$ & $<7$ & $<7$ \\
\hline
\end{tabular}

1 - dados referentes a E. grandis no estádio adulto; 2 - referentes a Eucalyptus spp; 3 - referentes a E. grandis no estádio juvenil. 
Tabela 5. Faixa deficiente e adequada das concentrações de potássio nas folhas recém maduras de espécies de Eucalyptus no estádio juvenil e adulto.

\begin{tabular}{|c|c|c|c|}
\hline \multirow{3}{*}{ Espécie } & \multicolumn{2}{|c|}{ Faixa } & \\
\hline & Deficiente & Adequada & \\
\hline & \multicolumn{2}{|c|}{$\mathrm{g} \mathrm{kg}^{-1}$} & Autor \\
\hline \multicolumn{4}{|c|}{ Estádio juvenil } \\
\hline E. globulus & $4-5$ & $10-15$ & Dell et al. (1995) \\
\hline E. globulus & $<4$ & $8-12$ & Boardman et al. (1997) \\
\hline$E \cdot$ grandis & - & $3,3-8,1$ & Novais et al. (1980) \\
\hline E. grandis & $<5$ & $12-14$ & Dell et al. (1995) \\
\hline E. cloeziana & & $7,0-13,8$ & Novais et al. (1980) \\
\hline E. pellita & $3-4$ & $9-15$ & Dell et al. (1995) \\
\hline E. urophylla & $3-5$ & $15-18$ & Dell et al. (1995) \\
\hline E. urophylla & - & $8-14$ & Huoran \& Wenlong (1996) \\
\hline$E \cdot$ nitens & $<4$ & 8 & Turnbull et al. (1994) \\
\hline$E \cdot$ pilularis & $<3$ & $3,5-5$ & Cromer et al. (1981) \\
\hline E. saligna & - & 11 & Yost et al. (1987) \\
\hline E. camaldulensis & - & $6-10$ & Boardman et al. (1997) \\
\hline E. maculata & $<4$ & $10-17$ & Dell et al. (1996) \\
\hline \multicolumn{4}{|c|}{ Estádio adulto } \\
\hline$E \cdot$ saligna & $<6$ & $8,5-10$ & Silveira et al. (1998) \\
\hline$E \cdot$ grandis & $<7$ & $8-10$ & Silveira et al. (1998) \\
\hline$E \cdot$ grandis & $5-6$ & $9-18$ & Dell et al. (1995) \\
\hline$E \cdot$ grandis & $<5$ & $6-18$ & Boardman et al. (1997) \\
\hline E. globulus & $<4,5$ & $5-12$ & Boardman et al. (1997) \\
\hline$E \cdot$ grandis $\mathrm{x} E$. urophylla & $2-6$ & $9-15$ & Dell et al. (1995) \\
\hline Eucalyptus spp & $6-8$ & $10-12$ & Malavolta (1987) \\
\hline E. globulus & $4-7$ & $9-11$ & Dell et al. (1995) \\
\hline E. camaldulensis & $<6$ & $6-8$ & Boardman et al. (1997) \\
\hline E. urophylla & $=$ & $8-14$ & Dell et al. (1995) \\
\hline E. dunnii & - & $8-15$ & Boardman et al. (1997) \\
\hline Variação & $2-7$ & $3,5-18$ & - \\
\hline
\end{tabular}




\subsubsection{Interações entre potássio e outros nutrientes}

Os efeitos interiônicos entre $\mathrm{K}, \mathrm{Ca}$ e $\mathrm{Mg}$ ocorrem na forma de inibição competitiva, normalmente ao nível de membrana celular (Epstein, 1975). Segundo Malavolta (1980), esse processo ocorre quando dois elementos se combinam pelo mesmo sítio ativo do carregador. Um exemplo clássico é dado pelas altas doses de potássio no meio, inibindo a absorção de $\mathrm{Ca}$ e $\mathrm{Mg}$, chegando muitas vezes a causar a deficiência desses dois nutrientes com queda de produção. Marschner (1995) também relata que cátions como o potássio podem atravessar a membrana plasmática com maior velocidade, deprimindo a absorção de cátions mais lentos como $\mathrm{Ca}$ e $\mathrm{Mg}$. A absorção preferencial do íon $\mathrm{K}^{+}$ocorre por ser monovalente e de menor grau de hidratação quando comparado aos divalentes (Kabata Pendias \& Pendias, 1984).

Schonau (1981) ao estudar o efeito da aplicação de fertilizantes sobre os teores foliares dos nutrientes em $E$. grandis, verificou que a aplicação de $\mathrm{K}$ reduzia os teores de $\mathrm{Ca}, \mathrm{Zn}$ e $\mathrm{Fe}$ e não afetava os de $\mathrm{Mg}$, enquanto que a fertilização fosfatada e a aplicação de calcário diminuía os teores de K nas folhas. Schmidt (1995) avaliou o crescimento e a absorção de $\mathrm{K}, \mathrm{Ca}$ e $\mathrm{Mg}$ por mudas de E. camaldulensis e E. grandis em resposta à aplicação de $\mathrm{K}$ no solo $\left(0,30,90,180 \mathrm{e} 270 \mathrm{mg} \mathrm{kg}^{-1}\right)$ e a adição de corretivos com diferentes relações $\mathrm{Ca} / \mathrm{Mg}$. Verificou que a dose de $\mathrm{K}$ para obter $90 \%$ da produção máxima foi de 60,7 e $50,7 \mathrm{mg}$ de $\mathrm{K} \mathrm{kg}^{-1}$, na presença de corretivo, para E. camaldulensis e E. grandis, respectivamente. Constatou ainda que com o aumento do nível de corretivo, uma maior quantidade de $\mathrm{K}$ foi necessária para manter o balanço catiônico e proporcionar uma maior produção de matéria seca.

Em E. fatigata com 3 anos de idade, Knight (1988) verificou correlações significativas e negativas entre a concentração de potássio e a de cálcio $(r=-0,70)$ e a de magnésio nas folhas $(r=-0,84)$. 


\subsection{Interações entre sulfato, cloreto e nitrato}

Malavolta et al. (1997) citam que os efeitos do íon $\mathrm{Cl}^{-}$sobre absorção do $\mathrm{SO}_{4}{ }^{-2}$ e $\mathrm{NO}_{3}{ }^{-}$ocorrem na forma de inibição competitiva, ou seja, esses ânions competem pelo mesmo sítio ativo do carregador. Os mesmos autores comentam ainda que para o cloro exercer suas funções na planta, em geral, não são necessários mais do que $100 \mathrm{mg}$ $\mathrm{kg}^{-1}$ de MS. Entretanto, o tecido vegetal pode apresentar valores de 20-200 vezes maior, sendo isto um indicativo de que o cloro não chega a ser tóxico em concentrações relativamente altas.

Boardman et al. (1997) citam que a faixa adequada de cloro nas folhas de $E$. globulus juvenil e E. saligna adulto está em torno de 3,3 a 6,0 e 1,0 a $4,5 \mathrm{~g} \mathrm{~kg}^{-1}$, mostrando que os materiais genéticos de Eucalyptus podem responder diferenciadamente ao cloro. Para E. grandis, na fase juvenil, os valores acima de 4,0 g $\mathrm{kg}^{-1}$ são considerados altos. Na fase adulta, a faixa compreendida entre 5,0 a $10,0 \mathrm{~g} \mathrm{~kg}^{-1}$ é alta, e para valores acima destes é considerada tóxica.

\subsection{Resposta do Eucalyptus à aplicação de potássio}

O Eucalytpus tem apresentado resposta à aplicação de $\mathrm{K}$ em solos com teor de 0,2 até $1,0 \mathrm{mmol}_{\mathrm{c}}$ de $\mathrm{K} \mathrm{dm}^{-3}$ de solo, conforme verificados por Barros et al. (1981), Barros \& Novais (1990, 1996), Stape \& Zani Filho (1990), Galo (1993), Scatolini et al. (1996), Valeri et al. (1996) e Gava (1997). Nos solos com valores acima de 1,0 mmol $\mathrm{dm}^{-3}$, os resultados têm sido contraditórios, sendo que na maioria das vezes não se encontram respostas à aplicação deste nutriente e quando ocorre são justificadas pela estreita relação $\mathrm{Ca}: \mathrm{Mg}$ (< 1 unidade) ou pelos elevados valores de $\mathrm{Ca}+\mathrm{Mg}$ no solo $(>8$ $\mathrm{mmol}_{\mathrm{c}} \mathrm{dm}^{-3}$ ). Novais et al. (1980) verificaram que E. grandis, na fase de muda, não respondeu a aplicação de potássio, o contrário foi observado para E. cloeziana. Os autores ainda sugerem que o nível crítico de $\mathrm{K}$ no solo para $E$. grandis, na fase inicial do crescimento, está abaixo de $0,23 \mathrm{mmol}_{\mathrm{c}} \mathrm{dm}^{-3}$ (extrator Mehlich 1), quando o solo é pobre em Ca e Mg. Para E. cloeziana, os valores estavam na faixa de 0,28 a 0,79 $\mathrm{mmol}_{\mathrm{c}} \mathrm{dm}^{-3}$, sendo que os valores mais altos foram obtidos para solos que receberam calagem. Ainda 
em relação ao nível crítico de $\mathrm{K}$ no solo para o crescimento de mudas de $E$. grandis, Prezotti (1985) verificou que os níveis para obtenção de $90 \%$ da produção máxima foram de 1,20 a 1,33 $\mathrm{mmol}_{\mathrm{c}} \mathrm{dm}^{-3}$ para solos de textura média a arenosa e 1,87 a 2,18 $\mathrm{mmol}_{\mathrm{c}} \mathrm{dm}^{-3}$ para os de textura argilosa. Estes valores foram mais altos que os encontrados por Novais et al. (1980), sendo justificados em razão do pequeno volume de solo $\left(400 \mathrm{~cm}^{3}\right)$ que foi utilizado para a produção das mudas.

Resultados semelhantes aos encontrados por Novais et al. (1980) também foram verificados por Sgarbi et al. (1997), que não constataram redução no crescimento de E. grandis $\mathrm{x}$ E. urophylla quando cultivado na ausência de potássio em relação ao tratamento completo.

Valeri et al. (1991) estudaram o efeito de doses de $\mathrm{N}\left(0,33\right.$ e $\left.66 \mathrm{~kg} \mathrm{ha}^{-1}\right)$, $\mathrm{P}_{2} \mathrm{O}_{5}\left(0,100\right.$ e $\left.200 \mathrm{~kg} \mathrm{ha}^{-1}\right)$ e $\mathrm{K}_{2} \mathrm{O}\left(0,33\right.$ e $\left.66 \mathrm{~kg} \mathrm{ha}^{-1}\right)$ e calcário dolomítico $\left(0\right.$ e $\left.2 \mathrm{t} \mathrm{ha}^{-1}\right)$ na produção de $E$. grandis plantado em areia quartzosa, na região de Luís Antônio/SP. Não verificaram aumentos na produção de madeira com a aplicação de nitrogênio e fósforo. Em relação ao potássio, ocorreu efeito quadrático, sendo que a máxima produção (86 st ha ${ }^{-1}$ ) foi obtida com a dose estimada de $61 \mathrm{~kg} \mathrm{~K}_{2} \mathrm{O} \mathrm{ha}^{-1}$. O E grandis também respondeu a aplicação de calcário, com aumento de $13 \%$ no volume de madeira em relação aos tratamentos que não receberam calagem. Valeri et al. (1996) estudaram o efeito do parcelamento e de doses de potássio $\left(0,50\right.$ e $100 \mathrm{~kg}$ de $\left.\mathrm{K}_{2} \mathrm{O} \mathrm{ha}^{-1}\right)$ nos 5 primeiros anos após o plantio, em areia quartzosa e latossolo vermelho escuro álico. Concluíram que no latossolo, o maior incremento em volume foi obtido com a aplicação de $50 \mathrm{~kg}$ de $\mathrm{K}_{2} \mathrm{O} \mathrm{ha}^{-1}$, parcelada nos 4 ou 5 primeiros anos, enquanto que na areia quartzosa, com aplicação de $100 \mathrm{~kg}$ de $\mathrm{K}_{2} \mathrm{O} \mathrm{ha}^{-1}$, parcelada em doses iguais nos cinco primeiros anos ou em doses crescentes nos 4 primeiros anos.

Barros \& Novais (1990) relataram que a necessidade de potássio aumenta com o acúmulo de biomassa e, portanto, com a idade do Eucalyptus. De acordo com os resultados de Barros \& Novais (1990), Rocha Filho et al. (1978) cultivando mudas de $E$. urophylla para obtenção de sintomas de deficiência dos macronutrientes, boro e ferro, constataram que os sintomas de carência de potássio foram os últimos a aparecer. Plantas jovens requerem pouco potássio e solos com níveis de $\mathrm{K}$ em torno de 0,51 
$\mathrm{mmol}_{\mathrm{c}} \mathrm{dm}^{-3}$ (20 mg kg$\left.{ }^{-1}\right)$ são suficientes para o crescimento inicial das mudas segundo Barros \& Novais (1990). Entretanto, Barros et al. (1981) encontraram respostas à aplicação de potássio no plantio $\left(27 \mathrm{~g} \mathrm{~K}_{2} \mathrm{O}\right.$ planta $\left.^{-1}\right)$ para $E$. saligna cultivado em solo com $0,67 \mathrm{mmol}_{\mathrm{c}}$ de $\mathrm{K} \mathrm{dm}^{-3}$, ocorrendo incrementos de $67 \%$ no volume de madeira aos 78 meses de idade. Resultados semelhantes foram obtidos quando estudaram o efeito da aplicação de potássio $\left(0,60,120,180\right.$ e $240 \mathrm{~kg}$ de $\left.\mathrm{K}_{2} \mathrm{O} \mathrm{ha}^{-1}\right)$ sobre a produção de biomassa de $E$. grandis cultivado em solo com $0,54 \mathrm{mmol}_{\mathrm{c}} \mathrm{de} \mathrm{K} \mathrm{dm}^{-3}$. Verificaram que a produção máxima aos 6,5 anos foi obtida com a dose de $179 \mathrm{~kg}$ de $\mathrm{K}_{2} \mathrm{O} \mathrm{ha}^{-1}$, a qual aumentou em 63 \% a produção quando comparada com a ausência de K na adubação (Barros et al., 1992). Esses resultados são concordantes com os obtidos por Gava (1997), ao estudar o efeito da aplicação de K $\left(0 ; 60 ; 120 ; 180 ; 240\right.$ e $\left.360 \mathrm{~kg} \mathrm{de} \mathrm{K}_{2} \mathrm{O} \mathrm{ha}^{-1}\right)$ em $E$. grandis sob condição de $2^{\mathrm{a}}$ rotação, plantados em dois solos, um com teor de 0,35 (podzólico vermelho amarelo, distrófico, textura arenosa/média localizado em Angatuba/SP) e outro com 1,7 $\mathrm{mmol}_{\mathrm{c}} \mathrm{de} \mathrm{K} \mathrm{dm}^{-3}$ (podzólico vermelho amarelo, textura média arenosa/argilosa localizado em São Miguel Arcanjo/SP). Observou resposta à aplicação de $\mathrm{K}$ até $256 \mathrm{~kg}$ de $\mathrm{K}_{2} \mathrm{O}$ ha $^{-1}$, no solo mais pobre em potássio, com aumento de $118 \%$ em volume de madeira em relação a testemunha. A dose de $\mathrm{K}_{2} \mathrm{O}$ para a obtenção de $90 \%$ da produção máxima foi de $145 \mathrm{~kg} \mathrm{ha}^{-1}$. No entanto, para o solo com nível mais elevado de potássio, a resposta à adição desse macronutriente foi nula. Scatolini et al. (1996) também obtiveram resultados similares para povoamentos de E. grandis localizados em solos com baixo teor de $\mathrm{K}$ trocável $\left(0,7 \mathrm{mmol}_{\mathrm{c}} \mathrm{dm}^{-3}\right)$, na região do Vale

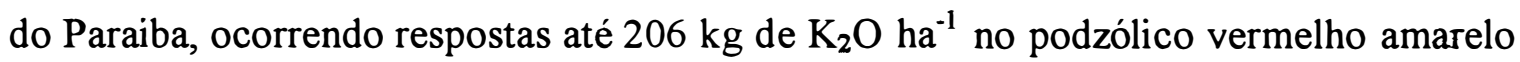
textura argilosa e $240 \mathrm{~kg}$ de $\mathrm{K}_{2} \mathrm{O}$ ha $^{-1}$ no latossolo vermelho amarelo textura média. Em outro estudo, Galo (1993) encontrou que a dose para se alcançar $90 \%$ da produção máxima de madeira para $E$. grandis aos 6,5 anos de idade, foi de $108 \mathrm{~kg}$ de $\mathrm{K}_{2} \mathrm{O} \mathrm{ha}^{-1}$, em solos cerrado de Itamarandiba/MG, cujo o teor original de $\mathrm{K}$ era de $0,59 \mathrm{mmol}_{\mathrm{c}} \mathrm{dm}^{-3}$. Neste estudo, os ganhos de produtividade com a aplicação de potássio foram de $92 \%$ quando comparou-se a dose de $200 \mathrm{~kg}$ de $\mathrm{K}_{2} \mathrm{O} \mathrm{ha}{ }^{-1}$ em relação a testemunha. 
Stape \& Benedetti (1997) constataram respostas de $E$. grandis, em $2^{\underline{a}}$ rotação na região de Itirapina/SP, à aplicação de NK, principalmente o potássio, conforme já verificado por Gava (1997) para E. grandis na região sul do estado de São Paulo.

\subsection{Relação entre o potássio e a putrescina, espermidina e espermina}

A diamina putrescina e as poliaminas espermidina e espermina são de ocorrência comum nas plantas superiores. A putrescina é sintetizada a partir dos aminoácidos arginina e ornitina, pelas enzimas arginina descarboxilase e ornitnina descarboxilase, respectivamente. De acordo com Galston (1989) e Smith (1985) a putrescina é convertida em espermidina e espermina, por sucessivas transferências de 1 ou 2 grupos aminopropil via descarboxilação do S-adenosil (Figura 2).

As poliaminas estão envolvidas no processo da divisão celular (Maki et al., 1991), nos processos de desenvolvimento e crescimento (Smith, 1985 e Evans \& Malmberg, 1989), na senescência (Smith, 1985 e Galston \& Kaur-Sawhney, 1990) e na regulação do metabolismo dos ácidos nucléicos (Kaur-Sawhney \& Galston, 1991).

As plantas nutricionalmente estressadas apresentam aumento na intensidade da biossíntese de di e poliaminas, principalmente putrescina. Em diversas plantas, verificou-se que a carência de potássio induziu o acúmulo da amina putrescina nas folhas conforme relatado pelo trabalho pioneiro de Richards \& Coleman (1952) em cevada, por Crocomo et al. (1974b) em Phaseolus vulgaris, Crocomo \& Basso (1974a) em Sesamum, Zaidan et al. (1999) em Musa sp. O acúmulo de putrescina na deficiência de potássio, pode ser explicado pelo mecanismo proposto por Coleman \& Richards (1956), admitindo-se que a falta de potássio altera o balanço interno entre cátions e ânions inorgânico, esperaria-se um aumento da acidez do suco celular, o que não ocorre. Portanto, esses autores sugeriram que o acúmulo de putrescina operaria como um mecanismo interno de compensação para manter o $\mathrm{pH}$ a um valor fisiologicamente adequado. De acordo com Murty et al. (1971) e Smith (1984), até $30 \%$ do déficit de cátion devido a deficiência de $\mathrm{K}$ poderia ser balanceado pela putrescina. Portanto, $\mathrm{o}$ efeito da putrescina na manutenção do $\mathrm{pH}$ celular é um dos mecanismos propostos da 
sua atuação, sendo um fator relevante nos estudos de nutrição mineral, especialmente com potássio.

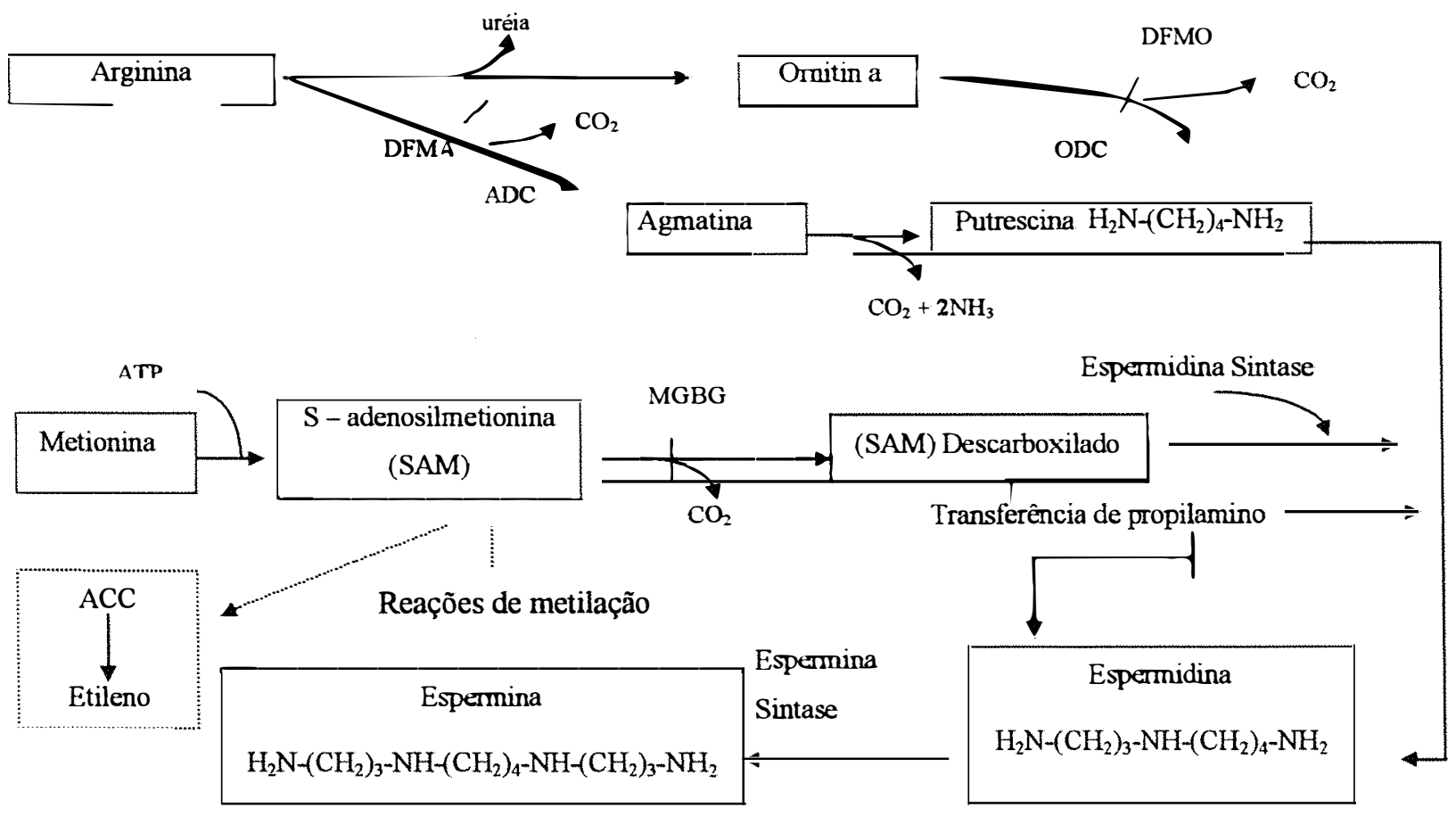

ADC (arginina descarboxilase); ODC (omitina descarboxilase); DFMA ( $\alpha$-difluorometilarginina); DFMO ( $\alpha$-difluorometilomitina); MGBG (metilglutaril-bis-guanilhidrazone): ACC (1-aminociclopropano-1-ácido carboxílico).

Figura 2. Esquema da biossíntese de poliaminas em plantas superiores (Galston, 1989).

Poucos estudos mostram a relação entre o potássio e a putrescina em espécies florestais. O nível de poliaminas tem sido investigado em algumas espécies de coniferas durante épocas do ano, uma vez que a quantidade das aminas parece estar relacionada com o início e o final da brotação, bem como, com a atividade cambial (Königshofer, 1989, 1990 e 1991). Sarjala \& Kaunisto (1993) verificaram que ocorria paralização do acúmulo de putrescina em Pinus sylvestris quando a concentração de potássio nas acículas estava acima de $5,5 \mathrm{~g} \mathrm{~kg}^{-1}$ no verão e $5,0 \mathrm{~g} \mathrm{~kg}^{-1}$ no inverno. Observaram ainda, que conforme a concentração de potássio nas acículas diminuía para valores abaixo de $4,3 \mathrm{~g} \mathrm{~kg}^{-1}$ no verão e $3,5 \mathrm{~g} \mathrm{~kg}^{-1}$ no inverno, ocorria um aumento exponencial da concentração de putrescina. Sarjala \& Kaunisto (1996) também 
estudaram a variação sazonal das poliaminas (putrescina, espermidina e espermina) e a concentração de potássio nas acículas de Pinus sylvestris em resposta à aplicação de potássio. Observaram que a concentração de putrescina nas acículas foi maior no inverno e na ausência de adubação potássica e, que a relação putrescina/espermidina inferior a 5 indicava concentração adequada de potássio nas acículas, independente da época do ano.

Em Picea abies, Kaunisto \& Sarjala (1997) encontraram correlação negativa entre a concentração de $\mathrm{K}$ nas folhas e o nível de putrescina, com relação linear para

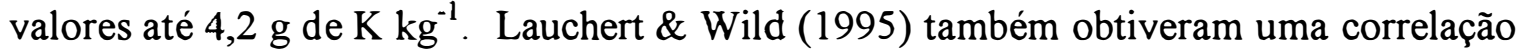
linear negativa entre a concentração de putrescina e o teor de potássio nas folhas de Picea abies (spruce). Porém, esta correlação estendia-se para valores de $\mathrm{K}$ nas folhas acima do limite da faixa de deficiência, contrário ao observado por Kaunisto \& Sarjala (1997).

Houman et al. (1991) estudaram o efeito do potássio (0; 11,7 e $117 \mathrm{mg}$ de $\mathrm{K}$ $\left.\mathrm{L}^{-1}\right)$ e do fósforo $\left(0 ; 1,55\right.$ e $15,5 \mathrm{mg}$ de $\left.\mathrm{P} \mathrm{L}^{-1}\right)$, em solução nutritiva, sobre o nível de putrescina, espermidina e espermina nas folhas e raízes de Populus moximowiczii. Na falta de potássio, a concentração de putrescina nas raízes e folhas foi 80 e 25 vezes maior que a encontrada na dose de $117 \mathrm{mg} \mathrm{K} \mathrm{L}^{-1}$, respectivamente.

Em relação a espermidina e espermina, Sarjala \& Kaunisto $(1993,1996)$ encontraram um leve decréscimo dessas aminas em acículas de Pinus sylvestris com baixa concentração de potássio, porém, não significativo estatisticamente. Resultados semelhantes foram obtidos por Sarjala (1996) em mudas de Pinus sylvestris, onde baixos níveis de espermidina e espermina foram obtidos em condições de deficiência de potássio. Entretanto, incrementos de espermina nas acículas de Picea abies foram encontrados na deficiência de potássio (Kaunisto \& Sarjala, 1997), indicando que a resposta da espermina as concentrações de potássio em Picea abies parece ser diferente a observada em Pinus sylvestris por Sarjala e Kaunisto (1993, 1996) e Sarjala (1996). 
Richards \& Coleman (1952) verificarăm que o máximo acúmulo de putrescina coincidia com o aparecimento de severos sintomas visuais de deficiência de K (necrose dos tecidos). Smith (1963) relata que em tecidos necrosados o teor de putrescina pode atingir até $140 \mu \mathrm{mol} \mathrm{g}^{-1}$ de MS.

\subsection{Efeitos da adubação e do estado nutricional sobre as características físicas, anatômicas e químicas da madeira}

Em razão dos plantios de Eucalyptus concentrarem em solos arenosos de baixa fertilidade natural, a adubação tem-se sido imprescindível para aumento e manutenção da produtividade. Como mostra os trabalhos com a aplicação de fósforo tanto no sulco como na cova de plantio (Barros et al., 1981; Valeri et al., 1983), potássio em cobertura nos povoamentos de $1^{\text {a }}$ e $2^{\text {a }}$ rotação (Valeri et al., 1991; Galo, 1993 e Gava, 1996) e boro em solos arenosos com períodos de déficit hídrico durante o ano (Tokeshi et al.; 1976; Barros et al.; 1992; Stape, et al., 1992; Fonseca et al.; 1993). Embora os estudos mostrem que a adubação promove ganhos de produtividade, pouco se conhece sobre os seus efeitos na qualidade química, fisica e anatômica da madeira do Eucalyptus. Alguns trabalhos foram realizados mostrando o efeito da adubação sobre as propriedades da madeira de coníferas de clima temperado (Siddiqui, 1973; Cutter \& Murphy, 1978; Shepard \& Shottafer, 1979; Brix \& Mitchell, 1980; Lindstrom, 1996; Dunisch et al., 1998), de Eucalyptus (Melo, 1968; Higgs \& Rudman, 1973; Bamber et al., 1982; Andrade et al., 1994; Sgarbi et al., 1999), e Pinus ( Malavolta et al., 1966; Gray \& Zeeuw, 1975; Downes \& Turvey, 1986; Yang et al., 1988). A maioria desses estudos tiveram como objetivo verificar o efeito da aplicação conjunta de NPK ou de fertilizantes nitrogenados, sem a preocupação de determinar os efeitos isolados ou das interações entre os nutrientes sobre a qualidade da madeira. Portanto, não se tem uma avaliação concreta da influência dos nutrientes na formação e nas características físicas e químicas da madeira.

Segundo Barrichelo \& Shimoyama (1994), a formação da madeira e suas características são dependentes da atividade cambial e da diferenciação dos xilemas, os 
quais são controlados pela produção de hormônios nas gemas apicais e o transporte de carboidratos das folhas para o câmbio. Deficiências e desequilíbrios nutricionais reduzem a biomassa foliar das árvores, e consequentemente a eficiência fotossintética e a atividade das gemas apicais, proporcionando um menor suprimento de carboidratos e hormônios para a região cambial (Brix, 1971). Um trabalho mais recente mostra que a quantidade de sacarose e ácido indol acético (AIA) nos tecidos do câmbio foi maior nas árvores com alta taxa de crescimento quando comparadas com as de baixa. Porém, não houve relação entre a concentração de AIA e sacarose na região cambial e a produção de traqueídeos (Sundberg et al., 1993). No entanto, outros estudos mostraram que essas substâncias regulam a divisão das células do câmbio e a formação da madeira em Pinus sylvestris (Sundberg et al., 1991 citado por Sundberg et al., 1993) e que a aplicação exógena desses compostos estimula a produção de traqueídeos em Pinus sylvestris (Zjaczkowski, 1973 e Little \& Savidge, 1987).

Provavelmente, o primeiro trabalho realizado no Brasil referente aos efeitos dos nutrientes na qualidade da madeira foi feito por Malavolta et al. (1966). Os autores não observaram efeito das doses de $\mathrm{N}, \mathrm{P}$ e $\mathrm{K}$ na solução nutritiva sobre a concentração de celulose em Pinus elliotii com 18 meses de idade. Entretanto, constataram que nos maiores níveis de nitrogênio ocorriam decréscimos do comprimento e da espessura da parede celular dos traqueídeos. Os efeitos do fósforo e potássio não ficaram evidentes para as características anatômicas.

Linnartz \& Thompson (1964) citados por Malavolta et al. (1966), verificaram que o comprimento dos traqueídeos de Pinus com 5 anos de idade aumentava linearmente em função das doses de $\mathrm{N}$ e K.

Estudando o efeito de 5 tratamentos de adubação (testemunha, N, P, NP e $\mathrm{NPK}+$ micronutrientes) sobre os componentes químicos da madeira de E. urophylla com 9 anos de idade, Jian Ju et al. (1998) notaram que a adubação não influenciou a concentração de celulose e lignina. No entanto, aumentou significativamente a concentração de extrativos e pentosanas da madeira quando comparada com a testemunha. 
Downes \& Turvey (1986) verificaram que as aplicações de altas doses de $\mathrm{N}$ e de $\mathrm{P}$ reduziram o conteúdo de lignina da parede celular dos traqueídeos de Pinus radiata.

A densidade básica é o índice mais utilizado para avaliar a qualidade da madeira em razão da facilidade de determinação. Ela é influenciada por vários fatores como: espessura da parede celular, quantidade de vasos e de parênquima, dimensões das fibras e teor de extrativos. Ela varia significativamente em função da taxa de crescimento, nível de produtividade, densidade populacional, idade, condições edafoclimáticas, espécie, procedência, progênies, e ainda dentro da mesma árvore no sentido base-topo e médula-casca (Brasil, 1972; Foelkel, 1975; Ferreira \& Kageyama, 1978; Rocha et al., 1983; Migliorini, 1986; Souza et al., 1986; Moraes, 1987; Tomazello Filho, 1985; Sturion et al.; 1987; Vale et al., 1995).

Williams \& Hamilton (1961) estudaram o efeito de 4 tratamentos de adubação (testemunha, sulfato de amônio, superfosfato triplo, sulfato de amônio + superfosfato triplo) sobre as características da madeira de Pinus elliotti e concluíram que nenhuma diferença foi encontrada para espessura da parede dos traqueídeos entre os tratamentos e que houve redução da densidade básica na seguinte ordem: sulfato de amônio $>$ sulfato de amônio + superfosfato $>$ superfosfato.

A aplicação de uréia (448 $\mathrm{kg}$ de $\mathrm{N} \mathrm{ha}^{-1}$ ) proporcionou menor porcentagem de madeira tardia e da espessura da parede dos traqueídos da madeira tardia de Pseudotsuga menziensii, com 24 anos de idade (Brix \& Mitchell, 1980). Efeitos similares em relação a porcentagem de madeira tardia, foram constados por Weetman (1971) em Picea mariana, com 65 anos de idade, mediante a fertilização nitrogenada. Jozsa \& Brix (1989) verificaram que a aplicação de $\mathrm{N}$ reduzia a densidade básica da madeira de Pseudotsuga menziensii. Resultados semelhantes foram obtidos com a aplicação de NPK em Eucalyptus regnans (Higgs \& Rudman, 1973), nitrogênio em Picea rubens (Shepard \& Shottafer, 1979) e em Pinus radiata (Woollons et al., 1995). Entretanto, Yordanov \& Skova (1989) ao estudarem a aplicação de nitrogênio $\left(0,150\right.$ e $\left.300 \mathrm{~kg} \mathrm{ha}^{-1}\right)$, fósforo e potássio $\left(0,75\right.$ e $\left.150 \mathrm{~kg} \mathrm{ha}^{-1}\right)$ em Pinus sylvetris, constataram que a fertilização nitrogenada proporcionou aumento de diâmetros sem reduzir a densidade básica da madeira. 
Balloni (1984) estudou o efeito de doses isoladas e combinadas de N, P, K e Ca sobre a qualidade da madeira de Pinus caribaea var bahamensis, com 13 anos de idade. Os principais resultados foram que: a aplicação de calcário causou redução na densidade básica da madeira, devido ao maior ritmo de crescimento das àrvores, ou seja, um aumento de $34 \%$ em volume quando comparado com a testemunha; a fertilização potássica promoveu ganhos de $9 \%$ em volume, por sua vez, teve a densidade básica reduzida somente em $4,5 \%$. Com base nesses resultados, o autor sugere que talvez o potássio atue diretamente sobre a densidade básica da madeira, independente do ritmo de crescimento.

Estudando o efeito da aplicação de doses isoladas ou combinadas de N (168 $\left.\mathrm{kg} \mathrm{ha}^{-1}\right)$, de $\mathrm{P}\left(72 \mathrm{~kg} \mathrm{ha}^{-1}\right)$ e de K (140 kg ha $\left.{ }^{-1}\right)$ sobre a qualidade da madeira de Picea rubens, Shepard (1982) observou que somente a fertilização conjunta de NPK reduziu a densidade básica, em $5 \%$.

Brito (1985) constatou que árvores de Pinus caribaea var. bahamensis adubadas com $60 \mathrm{~kg}$ de $\mathrm{N} \mathrm{ha}^{-1}, 100 \mathrm{~kg}_{\text {de }} \mathrm{P}_{2} \mathrm{O}_{5} \mathrm{ha}^{-1} ; 40 \mathrm{~kg}$ de $\mathrm{K}_{2} \mathrm{O}$ ha ${ }^{-1}$ e $3 \mathrm{t}$ de calcário dolomítico ha $^{-1}(33 \% \mathrm{CaO}$ e $8 \% \mathrm{MgO})$ tiveram a densidade básica reduzida em $23 \%$ quando comparadas com as árvores não adubadas.

Siddiqui (1972) estudou o efeito da fertilização sobre a qualidade da madeira e a produção de celulose em árvores de Pseudotsuga menziesii e Pinus resinosa, e constatou que a fertilização era responsável por: a) redução da porcentagem de madeira adulta; b) aumento da produção de celulose kraft; c) menor teor de extrativos; d) maior espessura da parede celular, especialmente da camada $S_{2}$ dos traqueídeos da madeira juvenil.

Gray \& Zeeuw (1975) observaram que a aplicação de potássio reduziu a espessura e o diâmetro da parede celular dos traqueídeos radiais da madeira adulta e a porcentagem de madeira tardia de Pinus radiata. Efeitos contrários foram verificados para a espessura e o diâmetro dos traqueídeos da madeira juvenil. Ainda encontraram decréscimo da densidade básica da madeira juvenil e adulta mediante à aplicação de potássio. Cutter \& Murphy (1978) também estudaram a influência do potássio (2 e 50 $\mathrm{mg}$ de $\mathrm{K} \mathrm{L}^{-1}$ ) sobre as características anatômicas da madeira, em híbrido de Populus ( $P$. 
maximowiczii com $P$. berolinensis Dipp). Constataram que os elementos de vasos, diâmetro e comprimento das fibras foram afetados pela concentração de potássio, bem como, a espessura da parede celular dos elementos de vasos. No entanto, não verificaram nenhuma influência do potássio sobre a espessura da parede celular das fibras.

Recentemente, Dunisch et al. (1998) observaram que o conteúdo de $\mathrm{K}$ e Ca durante a formação da madeira juvenil e adulta de Picea abies, afetou a formação da madeira juvenil. Durante a fase de elongação das células ocorreu um incremento do conteúdo de $\mathrm{K}$ do simplasto. $\mathrm{Na}$ fase de formação da parede celular aumentava-se o conteúdo de cálcio durante a diferenciação das células, entretanto, o conteúdo de cálcio da parede celular decresceu durante a sua lignificação. Os autores concluíram que o potássio é fundamental para a elongação e diferenciação dos traqueídeos, enquanto que o cálcio é essencial para a síntese da parede celular na fase secundária do desenvolvimento e no processo de lignificação.

Mello (1968) estudou o efeito da aplicação de N, P, K e calcário sobre a qualidade da madeira de Eucalyptus saligna, e verificou que a densidade básica, a espessura e o comprimento das fibras não foram afetados pela aplicação dos macronutrientes primários, com exceção feita a aplicação de calcário $\left(2 \mathrm{t} \mathrm{ha}^{-1}\right)$ que reduziu significativamente o comprimento das fibras. Em concordância, Andrade et al. (1994) constataram reduções significativas no comprimento das fibras e aumento no teor de extrativos da madeira de Eucalyptus grandis devido a aplicação de calcário calcítico $\left(2 \mathrm{t} \mathrm{ha}^{-1}\right)$. Ainda os mesmos autores verificaram que a aplicação de gesso e fosfato reduziu a presença de extrativos na madeira. A função do cálcio como nutriente estrutural é mencionado por Malavolta (1980), uma vez que a lamela média é rica em cálcio, e que este é responsável pelo aumento da rigidez da parede celular, dificultando o aumento do volume celular. Epstein (1975) e Malavolta (1980) relatam que a deficiência de cálcio provoca alterações na composição química e na estrutura da lamela média, bem como, aumenta a permeabilidade da membrana celular. Eklund \& Eliasson (1990) verificaram que altas concentrações de Ca no citoplasma de Picea abies estimulavam a 
deposição de lignina e polissacarídeos não celulósico na parede, enquanto que a deposição de celulose era quase que totalmente inibida. Ainda em relação ao cálcio, Sgarbi et al. (1999) observaram que a deficiência deste macronutriente em E. grandis $\mathrm{x}$ E. urophylla proporcionava madeira com menor concentração de lignina e fibras mais curtas quando comparada com o tratamento completo e com as deficiências de $\mathrm{N}, \mathrm{P}, \mathrm{K}$ e $\mathrm{Mg}$.

Bamber (1972), citado por Bevege $(1984)^{1}$, verificaram que o comprimento das fibras de Pinus pinaster com 10 anos de idade decrescia de $4 \mathrm{~mm}$ para 3,4 mm, mediante a aplicação de NPK. Porém, Gentle et al. (1968) não obtiveram respostas no comprimento das fibras de Pinus radita através da fertilização fosfatada. Resultados similares foram obtidos por Bamber et al. (1982) para Eucalyptus grandis com 2,5 anos de idade, uma vez que a aplicação de NPKS não teve efeito sobre o comprimento das fibras. Entretanto, para Eucalyptus regnans, a aplicação de NPK decresceu o comprimento das fibras e a densidade básica da madeira (Higgs \& Rudman, 1973). Ainda em relação as características anatômicas da madeira, Subrahmanyam (1988) verificou que altas doses de nitrogênio proporcionavam fibras mais extensas em Eucalyptus grandis, contrário foi observado para o fósforo. O nitrogênio e o fósforo não afetaram o diâmetro das fibras. No entanto, a parede celular foi mais espessa nas plantas cultivadas em altas doses de $\mathrm{P}$ e baixas de $\mathrm{N}$.

Yang et al. (1988) verificaram que o comprimento dos traqueídeos decresceu após a fertilização com $\mathrm{N}, \mathrm{P}$ e $\mathrm{S}$, sendo que altas doses de enxofre proporcionavam um maior decréscimo do comprimento dos traqueídeos de Pinus contorta var. latifolia. Ainda em relação ao enxofre, os resultados obtidos por Sgarbi et al. (1999) divergem dos encontrados por Yang et al. (1988), uma vez que ocorreu redução no comprimento das fibras e na densidade básica da madeira de E. grandis x

\footnotetext{
${ }^{1}$ - Bamber, R.K. (1972). In: The Australian Forest-Tree Nutrition Conference, 1971. Boardman, R. (Ed.), p.366-379.
} 
E. urophylla quando cultivado na ausência de enxofre em relação ao tratamento completo.

Os efeitos da aplicação de doses e formas de nitrogênio (amônio, nitrato e uréia) sobre as propriedades da madeira de Gmelina arborea foram estudados por Ogbonnaya (1993). Não houve diferença entre as fontes para a densidade básica da madeira. As fibras mais longas foram encontradas na presença de nitrato, as mais estreitas na presença de uréia, enquanto que as mais curtas e espessas nas plantas adubadas com $\mathrm{N}$ na forma amoniacal. Em outro trabalho, Ogbonnaya (1994) estudou o efeito da aplicação de doses de $\mathrm{N}(0 ; 2,2 ; 4,4$ e 6,6 g/vaso de 12,5 L) combinadas com doses de $\mathrm{K}(0 ; 5,7 ; 11,4$ e 17,1 g /vaso de 12,5L) sobre o crescimento e as características fisicas e histoquímicas da madeira de Gmelina arborea. Notou que o nitrogênio aumentou a densidade básica da madeira. As combinações NK também aumentaram o comprimento e a espessura das fibras, porém, sem efeitos na largura e no diâmetro do lume das fibras. Em relação a parte química, a concentração dos extrativos na madeira aumentou com as aplicações individuais de $\mathrm{N}$ e $\mathrm{K}$.

A Tabela 6 resume os principais efeitos dos nutrientes e das adubações nas características químicas, físicas e anatômicas da madeira de espécies florestais. 
Tabela 6. Efeito dos nutrientes e da adubação sobre as características da madeira.

\begin{tabular}{|c|c|c|c|}
\hline Efeito & Espécie & Alterações da madeira & Fonte \\
\hline \multicolumn{4}{|c|}{ Eucalyptus } \\
\hline$+\mathrm{NPK}$ & E. regnans & $\begin{array}{l}\text { Redução da densidade básica } \\
\text { e do comprimento das fibras }\end{array}$ & Higgs \& Rudman (1973) \\
\hline $\begin{array}{l}+\mathrm{N}+\mathrm{P} \\
+\mathrm{NP}+\mathrm{NPK}\end{array}$ & E. urophylla & Aumento de extrativos e pentosanas & Jian Ju et al. (1998) \\
\hline$-\mathrm{Ca}$ & E. grandis $\times$ E. urophylla & Menor teor de lignina e fibras mais curtas & Sgarbi et al. (1999) \\
\hline$+\mathrm{Ca}$ & $\begin{array}{l}\text { E. saligna } \\
\text { E. grandis }\end{array}$ & Redução do comprimento das fibras & $\begin{array}{c}\text { Mello (1968) } \\
\text { Andrade et al. (1994) }\end{array}$ \\
\hline$-S$ & E. grandis $\mathrm{x}$ E. urophylla & $\begin{array}{l}\text { Redução da densidade básica, teor de lignina e } \\
\text { comprimento das fibras }\end{array}$ & Sgarbi et al. (1999) \\
\hline$+\mathrm{Cu}$ & E. maculata & Maior taxa de lignificação & Dell (1994). \\
\hline \multicolumn{4}{|c|}{ Pinus } \\
\hline$+\mathrm{N}$ & $\begin{array}{l}\text { P. elliotti } \\
\text { P. radiata }\end{array}$ & $\begin{array}{c}\text { Decréscimo do comprimento e da espessura da } \\
\text { parede dos traqueideos } \\
\text { Redução da densidade básica }\end{array}$ & $\begin{array}{l}\text { Malavolta et al. (1966) } \\
\text { Woollons et al. (1995) }\end{array}$ \\
\hline$+\mathrm{K}$ & P. resinosa & $\begin{array}{l}\text { Redução da espessura da parede celular e diâmetro } \\
\text { dos traqueideos da madeira adulta, aumento da } \\
\text { espessura da parede celular e do diâmetro dos } \\
\text { traqueideos da madeira juvenil, redução da } \\
\text { densidade básica da madeira juvenil e adulta }\end{array}$ & Gray \& Zeeuw (1975) \\
\hline$+\mathrm{N}+\mathrm{P}$ & $\begin{array}{l}\text { P. radiata } \\
\text { P. elliotti }\end{array}$ & $\begin{array}{c}\text { Menor conteúdo de lignina na parede celular dos } \\
\text { traqueídeos } \\
\text { Menor densidade básica }\end{array}$ & $\begin{array}{c}\text { Downes \& Turvey } \\
\text { (1986) } \\
\text { Willians \& Hamilton } \\
(1961) \\
\end{array}$ \\
\hline$+\mathrm{N}+\mathrm{K}$ & Pinus spp & Aumento do comprimento dos traqueídeos & $\begin{array}{l}\text { Linnartz \& Thompson } \\
\text { (1964) citados por } \\
\text { Malavolta et al. (1966) } \\
\end{array}$ \\
\hline+ NPK & P. pinaster & Fibras mais curtas & Bamber et al. (1972) \\
\hline$+\mathrm{K}+\mathrm{Ca}$ & P. caribaea & Redução da densidade básica & Balloni (1984) \\
\hline+ NPS & P. contorta & $\begin{array}{l}\text { Decréscimo do comprimento dos traqueídeos. } \\
\text { principalmente para } \mathrm{S}\end{array}$ & Yang et al. (1988) \\
\hline + NPKCaMg & P. caribaea & Redução da densidade básica & Brito $(1985)$ \\
\hline \multicolumn{4}{|c|}{ Picea } \\
\hline$+\mathrm{N}$ & $\begin{array}{l}\text { P. abies } \\
\text { P. rubens }\end{array}$ & $\begin{array}{l}\text { Menor espessura da parede dos traqueídeos } \\
\text { Redução da densidade básica } \\
\text { Redução da densidade básica }\end{array}$ & $\begin{array}{l}\text { Weetman (1971) } \\
\text { Shepard \& Shottafer } \\
(1979)\end{array}$ \\
\hline$+\mathrm{K}$ & P. abies & Maior alongação e diferenciação dos traqueideos & Dunisch et al. (1998) \\
\hline$+\mathrm{Ca}$ & $\begin{array}{l}\text { P. abies } \\
\text { P. abies }\end{array}$ & $\begin{array}{c}\text { Maior deposição de lignina e polissacarídeos não } \\
\text { celulósico } \\
\text { Maior sintese de parede celular e lignificação na } \\
\text { fase secundária }\end{array}$ & $\begin{array}{c}\text { Eklund \& Eliasson } \\
\quad(1990) \\
\text { Dunisch et al. (1998) }\end{array}$ \\
\hline$+\mathrm{NPK}$ & P. rubens & Redução da densidade básica & Shepard (1982) \\
\hline \multicolumn{4}{|c|}{ Pseudotsuga } \\
\hline$+\mathrm{N}$ & P. menziensii & Menor espessura da parede dos traqueídeos & Brix \& Mitchell (1980) \\
\hline & $\begin{array}{l}\text { P. menziensii } \\
\text { P. menziensii } x \text {. } \\
\text { berolinensis }\end{array}$ & $\begin{array}{l}\text { Redução da densidade básica } \\
\text { Maior diâmetro e comprimento das fibras }\end{array}$ & $\begin{array}{l}\text { Jozsa \& Brix (1989) } \\
\text { Cutter \& Murphy (1978) }\end{array}$ \\
\hline & & Gmelina & \\
\hline$+\mathrm{NK}$ & G. arborea & $\begin{array}{l}\text { Aumento no comprimento e na espessura das } \\
\text { fibras bem como na concentracão de extrativos }\end{array}$ & Ogbonnaya (1994) \\
\hline
\end{tabular}




\section{MATERIAL E MÉTODOS}

\subsection{Local}

O experimento foi realizado sob condições de casa de vegetação no Departamento de Solos e Nutrição de Plantas da Escola Superior de Agricultura Luiz de Queiroz, Universidade de São Paulo, Piracicaba/SP.

\subsection{Escolha das progênies de Eucalyptus grandis}

As progênies de Eucalyptus grandis, origem Coffs Harbour utilizadas foram provenientes do pomar de semente clonal, de $2^{\underline{a}}$ geração, da Companhia Suzano de Papel e Celulose. Foram escolhidas 2 progênies consideradas não responsivas (Progênies 1 e 4) e 2 progênies responsivas a adubação (Progênies 2 e 3), com base nos resultados dos experimentos de adubação da empresa, localizados na região de Itatinga/SP, em solo areia quartzosa, latossolo vermelho amarelo e latossolo vermelho escuro.

\subsection{Obtenção e avaliação das mudas}

As mudas produzidas em tubete de polipropileno de $50 \mathrm{~cm}^{-3}$ contendo substrato "Plantmax" (Tabela 7), foram fertirrigadas diariamente dos 60 aos 90 dias com uma solução contendo (mg L $\left.{ }^{-1}\right)$ : 210 de N, 31 de P, 234 de K, 200 de Ca, 48 de $\mathrm{Mg}, 64$ de $\mathrm{S}, 0,5$ de $\mathrm{B}, 0,1$ de $\mathrm{Cu}, 3,0$ de $\mathrm{Fe}, 1,0$ de $\mathrm{Mn}$ e 0,2 de $\mathrm{Zn}$. Quando as mudas atingiram 110 dias de idade foram selecionadas, avaliadas e transplantadas para os baldes plásticos de $15 \mathrm{~L}$, contendo sílica moída. Antes do plantio, as mudas tiveram suas raízes lavadas com água para eliminar os resíduos do substrato.

Avaliou-se a biomassa e o estado nutricional das mudas antes da transferência para os baldes plásticos. Foram amostradas 10 mudas por progênie. As 
mudas foram coletadas e separadas em folhas, ramos + caule e raízes, sendo cada parte colocada em saco de papel e levada para secagem em estufa até atingir peso constante. Logo após, determinou-se o peso seco de cada parte da muda, procedendo a moagem do material visando as determinações dos macro e micronutrientes nos tecidos vegetais.

Tabela 7. Características químicas do substrato utilizado na produção de mudas.

\begin{tabular}{|c|c|}
\hline $\mathrm{pH}-\mathrm{CaCl}_{2}$ & 5,1 \\
\hline $\mathrm{MO}\left(\mathrm{g} \mathrm{dm}^{-3}\right)$ & 167 \\
\hline P resina $\left(\mathrm{mg} \mathrm{dm}^{-3}\right)$ & 232 \\
\hline $\mathrm{S}-\mathrm{SO}_{4}\left(\mathrm{mg} \mathrm{dm}^{-3}\right)$ & 57 \\
\hline $\mathrm{K}\left(\mathrm{mmol}_{\mathrm{c}} \mathrm{dm}^{-3}\right)$ & 7 \\
\hline $\mathrm{Ca}\left(\mathrm{mmol}_{\mathrm{c}} \mathrm{dm}^{-3}\right)$ & 130 \\
\hline $\mathrm{Mg}\left(\mathrm{mmol}_{\mathrm{c}} \mathrm{dm}^{-3}\right)$ & 100 \\
\hline $\mathrm{Al}\left(\mathrm{mmol}_{\mathrm{c}} \mathrm{dm}^{-3}\right)$ & 1 \\
\hline $\mathrm{H}+\mathrm{Al}\left(\mathrm{mmol}_{\mathrm{c}} \mathrm{dm}^{-3}\right)$ & 47 \\
\hline Soma de bases $\left(\mathrm{mmol}_{\mathrm{c}} \mathrm{dm}^{-3}\right)$ & 237 \\
\hline $\mathrm{CTC}\left(\mathrm{mmol}_{\mathrm{c}} \mathrm{dm}^{-3}\right)$ & 284 \\
\hline Saturação por bases (\%) & 83 \\
\hline Saturação por Al (\%) & 0 \\
\hline$B\left(\mathrm{mg} \mathrm{dm}^{-3}\right)$ & 3,6 \\
\hline $\mathrm{Cu}\left(\mathrm{mg} \mathrm{dm}^{-3}\right)$ & 2,1 \\
\hline $\mathrm{Fe}\left(\mathrm{mg} \mathrm{dm}^{-3}\right)$ & 57,6 \\
\hline $\operatorname{Mn}\left(\mathrm{mg} \mathrm{dm}^{-3}\right)$ & 29,2 \\
\hline $\mathrm{Zn}\left(\mathrm{mg} \mathrm{dm}^{-3}\right)$ & 22,8 \\
\hline
\end{tabular}

\subsection{Cultivo das plantas em solução nutritiva}

As mudas, transplantadas nos baldes, foram irrigadas na primeira semana com uma solução nutritiva contendo $\left(\mathrm{mg} \mathrm{L}^{-1}\right)$ : 42 de $\mathrm{N}, 6,2$ de $\mathrm{P}, 46,8$ de $\mathrm{K}, 40$ de $\mathrm{Ca}$, 9,6 de $\mathrm{Mg}, 12,8$ de S, 0,1 de B, 0,02 de $\mathrm{Cu}, 0,8$ de Fe, 0,2 de Mn e 0,04 de Zn. No período de 14 até os 67 dias de idade, as mudas foram irrigadas diariamente com uma solução nutritiva contendo (mg. $\mathrm{L}^{-1}$ ): 210 de N, 31 de P, 175 de K, 200 de Ca, 48 de $\mathrm{Mg}$, 64 de $\mathrm{S}, 0,5$ de $\mathrm{B}, 0,1$ de $\mathrm{Cu}, 3,0$ de $\mathrm{Fe}, 1,0$ de $\mathrm{Mn}$ e 0,2 de $\mathrm{Zn}$. A solução nutritiva foi renovada a cada 15 dias. Após esse período, foi realizada a lavagem do substrato com 
água destilada para remover os nutrientes retidos na sílica. Em seguida, iniciou-se o cultivo das progênies em solução nutritiva contendo todos os nutrientes $(\mathrm{N}, \mathrm{P}, \mathrm{Ca}, \mathrm{Mg}$, $\mathrm{S}, \mathrm{B}, \mathrm{Cl}, \mathrm{Cu}, \mathrm{Fe}, \mathrm{Mn}, \mathrm{Mo}$ e $\mathrm{Zn}$ ), com exceção do potássio, que foi testado nos níveis de $\left(\mathrm{mg} \mathrm{L}^{-1}\right): 0,58,5,175,5$ e 526,5 (Tabela 8). As plantas cultivadas na ausência de potássio foram inicialmente irrigadas com 19,5 mg de $\mathrm{K} \mathrm{L}^{-1}$. Entretanto, a avaliação de altura e diâmetro das mudas realizada aos 3 meses após o cultivo em doses de potássio, mostrou que não havia diferença significativa entre a dose de $19,5 \mathrm{mg}$ de $\mathrm{K} \mathrm{L}^{-1}$ e as doses de 58,5 e $175,5 \mathrm{mg}$ de $\mathrm{K} \mathrm{L}^{-1}$. Diante dos resultados, optou-se a partir dessa data pelo cultivo das

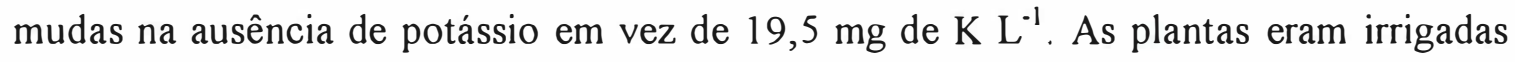
uma vez ao dia, no período da manhã. A drenagem das soluções era feita através de orifícios no fundo de cada vaso ligados com tubos plásticos aos frascos coletores com capacidade de 1 litro (Figura 3). A renovação da solução foi feita a cada 15 dias, tomando-se o cuidado de verificar diariamente o nível da solução nos frascos coletores, completando o volume a um litro, pela adição de água destilada.

\section{4 meses de idade}

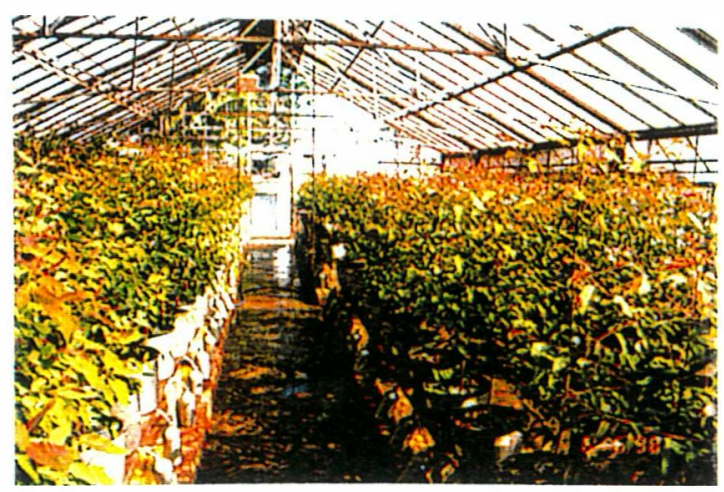

8 meses de idade

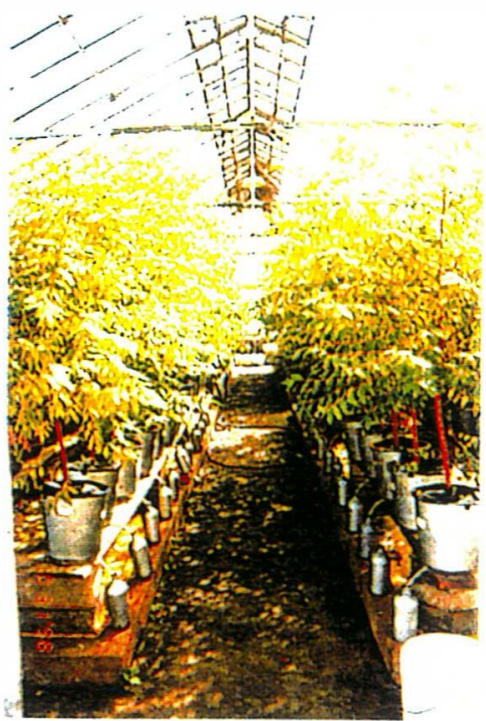

Figura 3. Visão geral do experimento. 
Tabela 8. Composição química dos tratamentos que foram usados no experimento ( $\left.\mathrm{mL} \mathrm{L}^{-1}\right)$.

\begin{tabular}{llcccc} 
Soluções & & \multicolumn{4}{c}{ Tratamentos $\left(\mathrm{mg} \mathrm{de} \mathrm{K} \mathrm{L}^{-1}\right)$} \\
\cline { 2 - 6 } Estoque & & 0 & 58,5 & 175,5 & 526,5 \\
$\mathrm{Ca}\left(\mathrm{NO}_{3}\right)_{2} 4 \mathrm{H}_{2} \mathrm{O}$ & $\mathrm{M}^{\mathrm{A}}$ & 5 & 5 & 5 & 5 \\
$\mathrm{MgSO}_{4} 7 \mathrm{H}_{2} \mathrm{O}$ & $\mathrm{M}$ & 2 & 2 & 2 & 2 \\
$\mathrm{NH}_{4} \mathrm{NO}_{3}$ & $\mathrm{M}$ & 2 & 2 & 2 & - \\
$\mathrm{NH}_{4} \mathrm{H}_{2} \mathrm{PO}_{4}$ & $\mathrm{M}$ & 1 & 1 & 1 & - \\
$\mathrm{KCl}$ & $\mathrm{M}$ & - & 1,5 & 4,5 & 7,5 \\
$\mathrm{KNO}_{3}$ & $\mathrm{M}$ & - & - & - & 5 \\
$\mathrm{KH}_{2} \mathrm{PO}_{4}$ & $\mathrm{M}$ & - & - & - & 1 \\
$\mathrm{Micronutrientes}^{\mathrm{B}}$ & & 1 & 1 & 1 & 1 \\
Fe-EDTA & & 1 & 1 & 1 & 1 \\
\hline
\end{tabular}

A - soluções molares; B - A solução de micronutrientes teve a seguinte composição ( $\mathrm{g} \mathrm{L}^{-2}$ ): $\mathrm{H}_{3} \mathrm{BO}_{3}=2,94 ; \mathrm{MnSO}_{4} \mathrm{H}_{2} \mathrm{O}=2,43$; $\mathrm{CuSO}_{4} 5 \mathrm{H}_{2} \mathrm{O}=0,07 ; \mathrm{ZnSO}_{4} 7 \mathrm{H}_{2} \mathrm{O}=0,21 ; \mathrm{H}_{2} \mathrm{MoO} 4 \mathrm{H}_{2} \mathrm{O}=0,02 ; \mathrm{C}$ - Foi dissolvido 26,1 $\mathrm{g}$ de EDTA dissódico em $286 \mathrm{ml}$ de $\mathrm{NaOH}$, misturou-se $24,9 \mathrm{~g}$ de $\mathrm{FeSO}_{4} 7 \mathrm{H}_{2} \mathrm{O}$. Arejou por uma noite e completou um litro com água destilada.

Os tratamentos $0,58,5,175,5$ e $526,5 \mathrm{mg} \mathrm{K} \mathrm{L}^{-1}$ apresentaram na sua composiçăo doses de cloro que foram de $0,53,2,159,7$ e $266,2 \mathrm{mg} \mathrm{L}^{-1}$, respectivamente.

A composição das soluções nutritivas foi baseada em Sarnuge (1975)

\subsection{Avaliações, colheita e preparo de material para análise química}

As plantas foram mensuradas através da altura e diâmetro basal a $10 \mathrm{~cm}$ no início e mensalmente até o final do experimento.

Os sintomas visuais de deficiência de potássio foram descritos e fotografados desde o estágio inicial até o mais avançado.

Aos 10 meses, após início dos tratamentos, as plantas foram coletadas e separadas em folhas novas (4 primeiras folhas localizadas nos ramos a partir do ápice), folhas diagnóstico ( $5^{\mathrm{a}}$ e $6^{\mathrm{a}}$ folha), folhas velhas (situadas abaixo da $6^{\mathrm{a}}$ folha), ramos, casca e lenho. As partes das plantas foram submetidas a uma lavagem rápida com água destilada e postas para secagem ao ar livre. Em seguida, cada parte da planta foi colocada em sacos de papel e levada para secagem em estufa de ventilação forçada a uma temperatura média de $65^{\circ} \mathrm{C}$, até atingir peso constante. Posteriormente, determinou-se o peso seco de cada parte da planta e a produção de matéria seca total.

Após a determinação da matéria seca, procedeu-se a moagem do material em moinho tipo Willey de acordo com as instruções de Malavolta et al. (1997). 


\subsection{Análise química do tecido vegetal}

As determinações dos macro e micronutrientes contidos no material vegetal foram realizadas no laboratório de análise foliar do Setor de Nutrição Mineral do CENA/USP.

As amostras secas e moídas das partes da planta, foram digeridas em ácido nítrico-perclórico ( $\mathrm{P}, \mathrm{K}, \mathrm{Ca}, \mathrm{Mg}, \mathrm{S}, \mathrm{Cu}, \mathrm{Fe}, \mathrm{Mn}$ e $\mathrm{Zn}$ ) e sulfúrico $(\mathrm{N})$ para a obtenção dos extratos, visando a determinação dos macro e micronutrientes, conforme metodologia descrita por Malavolta et al. (1997). A determinação de P foi realizada pelo método da colorimetria de molibdato-vanadato; $\mathrm{K}$ por fotometria de chama; $\mathrm{Ca}, \mathrm{Mg}, \mathrm{Cu}$, $\mathrm{Fe}, \mathrm{Mn}$ e $\mathrm{Zn}$ por espectrometria de absorção atômica; S por turbidimetria de suspensão de sulfato de bário; B por colorimetria de azometina. As determinações de nitrogênio foram feitas através do método micro Kjeldahl.

Nas folhas diagnóstico realizou-se a extração aquosa por agitação para obtenção de extratos, visando a determinação do cloro pelo método da titulometria do nitrato de prata, conforme Malavolta et al. (1997).

\subsection{Análise bioquímica das folhas}

Cerca de 30 dias antes do término do experimento ( 11 meses de idade), amostrou-se folhas diagnóstico ( $5^{\underline{a}}$ e $6^{\underline{a}}$ folha a partir do ápice) com o objetivo de realizar as análises de poliaminas e açúcares solúveis totais. Após a coleta, as folhas foram acondicionadas em sacos de papel e levadas até o liofilizador, onde permaneceram por 48 horas, a $-50^{\circ} \mathrm{C}$. Posteriormente, o material foi moído e mantido em dissecador durante aproximadamente 90 dias para ser analisado.

\subsubsection{Poliaminas}

Foram realizadas análises bioquímicas nas folhas usadas para a diagnose, visando determinar a concentração de putrescina, espermina e espermidina, de acordo com Flores \& Galston (1982). 


\subsubsection{Extração}

As folhas diagnóstico, na quantidade de $100 \mathrm{mg}$ de material seco, foram maceradas em $5 \mathrm{~mL}$ de ácido perclórico, em uma bandeja contendo gelo. Em seguida, fez-se a centrifugação durante 10 minutos a $10.000 \times \mathrm{g}$, a $4^{\circ} \mathrm{C}$, sendo que o sobrenadante (extrato perclórico) foi coletado e estocado em freezer a $-20^{\circ} \mathrm{C}$.

\subsubsection{Dansilação direta}

O extrato perclórico foi pipetado na quantidade de $200 \mu \mathrm{L}$ e colocado em tubos de ensaio, juntamente com $200 \mu \mathrm{L}$ de uma solução saturada de carbonato de sódio $\left(\mathrm{NaHCO}_{3}\right)$ e $400 \mu \mathrm{L}$ de cloreto de dansil (5-[Dimetilamino]naftaleno 1-sulfonil cloreto) diluído em acetona $\left(5 \mathrm{mg} \mathrm{mL}^{-1}\right)$.

Após 30 segundos de agitação em Vortex, os tubos de ensaio foram mantidos no escuro, à temperatura ambiente por 16 horas. Logo após, adicionou-se $100 \mu \mathrm{L}$ de prolina ( $100 \mathrm{mg} \mathrm{mL}^{-1}$ ) e incubou-se por 25 minutos para remover o excesso de dansil. A extração das poliaminas dansiladas foi realizada em $500 \mu \mathrm{L}$ de benzeno, após agitação durante 30 segundos em vortex, coletando-se a fase orgânica.

\subsubsection{Separação das poliaminas por cromatografia de camada delgada}

Foram usadas placas de vidro cromatográficas $(20 \times 20 \mathrm{~cm})$ cobertas com silicagel $60 \mathrm{G}-$ Merck $\left(250 \mu \mathrm{m}\right.$ de espessura), as quais haviam sido ativadas a $180^{\circ} \mathrm{C}$ por 1 hora. Sobre as placas aplicou-se $5 \mu \mathrm{L}$ do extrato dansilado.

O cromatograma foi desenvolvido em cubas de vidro, utilizando-se clorofórmio:trietilamina $(25: 2, \mathrm{v} / \mathrm{v})$ como fase móvel. A separação cromatográfica foi acompanhada de luz ultra-violeta (366 nm Original Hanau Qartzlampen GMBH). Padrões de putrescina, espermina e espermidina foram processados paralelamente nas mesmas condições experimentais, sendo aplicados na placa 7,5 $\mu \mathrm{L}$ (9 nmoles) de uma mistura contendo os três padrões das aminas, com 3 nmoles de cada. 


\subsubsection{Análise quantitativa de poliaminas separadas na cromatografia de camada delgada}

As placas desenvolvidas na cromatografia foram secas e submetidas a leitura da intensidade de fluorescência utilizando-se um densitômetro (Cliniscan II - Helena Laboratories). Pela ativação dos compostos dansilados com a luz UV à $365 \mathrm{~nm}$, mediuse a intensidade de fluorescência das manchas à $507 \mathrm{~nm}$. A interpretação e execução dos cálculos quantitativos foram feitas a partir dos resultados fornecidos pelo densitômetro ao sobrepor a integração dos picos referentes a cada amina das amostras, com aquelas integrações obtidas com os picos dos padrões de di e poliaminas.

\subsubsection{Açúcares solúveis totais}

As folhas diagnóstico na quantidade de $200 \mathrm{mg}$ foram transferidas para Erlenmeyer de $100 \mathrm{~mL}$, contendo $50 \mathrm{~mL}$ de água destilada e mantidas em banho-maria $\left(60^{\circ} \mathrm{C}\right)$ durante 30 minutos. Em seguida, filtrou-se o extrato e completou o volume a 100 $\mathrm{mL}$ em balão volumétrico. Uma alíquota de $0,5 \mathrm{~mL}$ desse extrato foi transferida para tubo de ensaio, adicionando-se $0,5 \mathrm{~mL}$ de fenol $5 \%$ e $2,5 \mathrm{~mL}$ de $\mathrm{H}_{2} \mathrm{SO}_{4}$ concentrado,

sendo essa solução homogeneizada em agitador mecânico (Vortex) e deixada em repouso durante 20 minutos. Posteriormente, realizou-se a leitura em espectrofotômetro Varian a $490 \mathrm{~nm}$, utilizando-se glicose p.a. como padrão. A metodologia descrita está baseada em Dubois et al. (1956).

\subsection{Características da madeira}

\subsubsection{Análise química}

Foram realizadas análises químicas da madeira contida no lenho das plantas, para quantificação dos teores de extrativos em álcool-tolueno, álcool e água quente, lignina e holocelulose (celulose + hemicelulose). A determinação desses componentes foi feita de forma simultânea. 
Pesou-se $1 \mathrm{~g}$ de serragem (mistura de lenho moído das porções basais, medianas e apicais) e transferiu-se para saquinhos de papel de filtro, colocando-se a amostra no corpo do extrator (Soxhlet). Em seguida, fez-se a extração com álcooltolueno (1:2) e álcool $96^{\circ} \mathrm{GL}$, durante 6 a 8 horas em cada solvente, deixando a amostra secar na temperatura ambiente. Após a secagem, toda a serragem dos saquinhos foi transferida para Erlenmeyer de $250 \mathrm{~mL}$, adicionando-se $100 \mathrm{~mL}$ de água destilada e colocando em banho-maria. Após 3 horas, filtrou-se todo o extrato através de cadinho sinterizado tarado, transferindo toda a serragem do Erlenmeyer para cadinho. Posteriormente, lavou-se o cadinho com $250 \mathrm{~mL}$ de água quente (quase em ebulição), antes de levá-lo à estufa, e mantê-lo até atingir peso constante. A percentagem de extrativos foi calculada pela expressão: $\%$ Extrativos $=(1-$ peso seco da serragem $) \mathrm{x}$ 100.

Utilizando-se a mesma serragem da determinação dos extrativos, transferiu-a para copo de $50 \mathrm{~mL}$, adicionando-se $15 \mathrm{~mL}$ de $\mathrm{H}_{2} \mathrm{SO}_{4} 72 \%$. O copo foi mantido no banho de água a $18-20^{\circ} \mathrm{C}$, durante 2 horas. Em seguida, transferiu-se todo o material para Erlenmeyer de 1 litro, acrescentando $560 \mathrm{~mL}$ de água destilada. A solução em Erlenmeyer ficou em ebulição durante 4 horas, mantendo-se o nível de água mediante a adição periódica de água destilada. Após 4 horas, deixou-se a lignina sedimentar totalmente (durante 24 horas). No dia seguinte, filtrou-se em cadinho, transferindo toda a lignina do Erlenmeyer para o cadinho, sendo que o Erlenmeyer foi lavado várias vezes com água destilada quente (quase em ebulição). Logo após, lavou-se a lignina contida no cadinho com $250 \mathrm{~mL}$ de água quente destilada, levando-a para secagem em estufa até atingir peso constante. A percentagem de lignina foi calculada pela expressão: \% Lignina $=$ peso seco do resíduo $\times 100$.

A porcentagem de holocelulose foi determinada pela expressão: \% de Holocelulose $=100-\%$ Extrativos $-\%$ Lignina .

\subsubsection{Análise física}

A densidade básica da madeira é a relação entre o seu peso (g) absolutamente seco e seu volume $\left(\mathrm{cm}^{-3}\right)$ quando em estado de completa saturação com água. 
A densidade básica foi determinada nas três porções do caule: basal a $10 \mathrm{~cm}$ de altura em relação a sílica; mediana a $30 \%$ e apical a $60 \%$ da altura das plantas. Pesou-se os corpos de prova com auxílio de uma balança hidrostática. Foi realizada uma pesagem ao ar e outra com o corpo de prova imerso em água. Em seguida, os corpos de prova foram secos em estufa com temperatura variando de $105 \pm 3^{\circ} \mathrm{C}$ até atingir peso constante. A densidade foi calculada pela seguinte expressão: $d=(P / V)$, onde $P=$ peso seco do corpo de prova em estufa; $\mathrm{V}=$ volume saturado.

\subsubsection{Análise anatômica}

Amostras de madeira contidas no lenho (base, meio e ápice) foram submetidas à análises anatômicas, onde foi determinado o comprimento, a largura, o diâmetro do lume e a espessura da parede de suas fibras após maceração pelo método do ácido nítrico-acético (Barrichelo \& Foelkel, 1983).

Foram cortados pequenos palitos do lenho e colocados em tubo de ensaio, adicionando-se água destilada, para facilitar a difusão da solução macerante. Em seguida, retirou-se a água dos tubos e adicionou-se a solução macerante (5 partes de ácido acético para 1 parte de ácido nítrico; diluindo a mistura de ácidos em água destilada na proporção de $1: 2$ ), cobrindo todo o material. A maceração foi realizada em banho-maria, sob ebulição, dentro de capela com exaustor, durante 45-60 minutos. Logo após, esgotou-se a solução macerante e lavou-se várias vezes com água, com posterior

armazenamento do material em água até o preparo das lâminas (Barrichelo \& Foelkel, 1983).

Da suspensão dos constituintes anatômicos, obtida pelo processo de maceração, coletou-se material para análise com auxílio de agulha histológica, transferindo-o para uma lâmina de vidro. Em seguida, colocou-se uma gota de corante safranina na lâmina e misturou-se com a suspensão.

Após a montagem das lâminas, observou-se o material para avaliação do comprimento das fibras através da imagem projetada no balcão, pelo projetor de fibras e largura, espessura da parede e diâmetro do lume através de microscópio ótico.

A fração parede foi calculada pela seguinte expressão: (EP x 2/LF) x 100, onde $\mathrm{EP}=$ espessura da parede das fibras e $\mathrm{LF}=$ largura das fibras. 


\subsection{Delineamento estatístico}

O experimento foi conduzido em delineamento inteiramente casualizado, em esquema fatorial $4^{2}$ ( 4 materiais genéticos de Eucalyptus grandis $\times 4$ doses de K), com 5 repetições. Foram feitas análises de variância (Tabela 9), teste de comparação de médias (Tukey 5\%), correlações e regressões entre: a) doses de $K$ na solução nutritiva $x$ diâmetro e produção de matéria seca; b) doses de $\mathrm{K}$ na solução nutritiva $\mathrm{x}$ concentração dos macro e micronutrientes nas partes da planta; c) doses de $\mathrm{K}$ na solução nutritiva $\mathrm{X}$ concentração de poliaminas e açúcares solúveis totais; d) doses de K na solução nutritiva x concentração de holocelulose, extrativos, lignina, comprimento, largura, espessura da parede, diâmetro do lume das fibras e densidade básica; e) concentração de potássio nas folhas diagnóstico x diâmetro, produção de matéria seca, concentração das poliaminas e açucares solúveis totais; f) concentração de potássio nas folhas diagnóstico e no lenho $\mathrm{x}$ concentração de holocelulose, extrativos, lignina, comprimento, largura, espessura da parede, diâmetro do lume das fibras e densidade básica; g) relações entre o potássio e os macronutrientes nas folhas diagnóstico x produção de matéria seca; $h$ ) relações entre $o$ potássio e os macronutrientes nas folhas diagnóstico e no lenho x concentração de holocelulose, extrativos, lignina, comprimento, largura, espessura da parede, diâmetro do lume das fibras e densidade básica.

Tabela 9. Esquema da análise de variância

\begin{tabular}{c|cc}
\hline \hline Causas de variação & Grau de Liberdade \\
\hline Progênies (a) & $(\mathrm{i}-1)$ & 3 \\
Doses de K (b) & $(\mathrm{k}-\mathrm{l})$ & 3 \\
a x b & $(\mathrm{i}-1) \times(\mathrm{k}-1)$ & 9 \\
\hline (Tratamentos) & $(\Sigma)$ & $(15)$ \\
Resíduo & {$\left[\mathrm{j}^{\mathrm{A}} \times(\mathrm{ik})-1\right]-\Sigma$} & 64 \\
\hline Total & $\mathrm{j} \times(\mathrm{ik})-1$ & 79 \\
\hline \hline
\end{tabular}

A - repetições. 


\section{RESULTADOS E DISCUSSÃO}

\subsection{Caracterização das mudas das progênies de Eucalyptus grandis}

\subsubsection{Produção de matéria seca}

As mudas da progênie 2 apresentaram menor quantidade de MS (matéria seca) acumulada de folhas, caule + ramos, raizes e total quando comparada com as demais progênies (Tabela 10). A produção percentual em relação a total variou de 37 a $41 \%$ para as folhas, 31 a $41 \%$ para o caule + ramos e 22 a $28 \%$ para raízes em função do material genético. Silveira et al. (1995a) e Camargo (1997) também encontraram o menor conteúdo de MS nas raízes para mudas de E. grandis produzidas através de sementes e estacas, respectivamente. Silveira et al. (1995a) observaram valores inferiores para MS de folhas $(0,58 \mathrm{~g} /$ muda $)$, caule $(0,41 \mathrm{~g} /$ muda $)$ e raízes $(0,29 \mathrm{~g} /$ muda $)$ em mudas de E. grandis aos 97 dias, que os encontrados para as progênies 1,3 e 4 (Tabela 10).

Tabela 10. Matéria seca produzida pelas mudas das progênies de Eucalyptus grandis, aos 110 dias de idade, na condição de tubete.

\begin{tabular}{|c|c|c|c|c|}
\hline \multirow{2}{*}{$\begin{array}{l}\text { Material } \\
\text { genético }\end{array}$} & Folhas & Caule + Ramos & Raizes & Total \\
\hline & \multicolumn{4}{|c|}{$\mathrm{g} / \mathrm{muda}$} \\
\hline Progênie 1 & $0,73(37)^{*}$ & $0,79(41)$ & $0,44(22)$ & 1,96 \\
\hline Progênie 2 & $0,51(41)$ & $0,45(37)$ & $0,28(22)$ & 1,24 \\
\hline Progênie 3 & $0,82(41)$ & $0,61(31)$ & $0,56(28)$ & 1,99 \\
\hline Progênie 4 & $0.65(37)$ & $0.67(39)$ & $0,42(24)$ & 1.74 \\
\hline
\end{tabular}

* - valores entre parènteses referem-se ao percentual em relaçào ao total. 


\subsubsection{Concentração dos macro e micronutrientes}

A concentração de $\mathrm{N}$ nas folhas das progênies 1, 3 e 4 encontrava-se abaixo da faixa considerada adequada para o crescimento de mudas de E. grandis (Dell, et

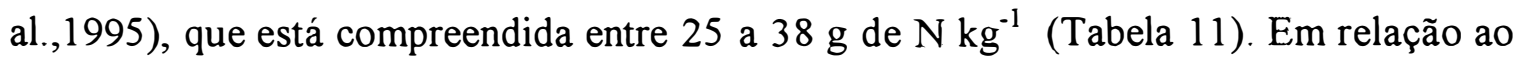
fósforo, potássio, cálcio e enxofre, os valores obtidos foram considerados adequados com base em Dell et al. (1995), o qual a faixa varia de 1,5 a 2,2 g de $\mathrm{P} \mathrm{kg}^{-1}, 9$ a $18 \mathrm{~g}$ de $\mathrm{K} \mathrm{kg}^{-1}, 5,0$ a 8,0 $\mathrm{g}_{\text {de }} \mathrm{Ca} \mathrm{kg}^{-1}$ e 1,5 a 2,3 $\mathrm{g}_{\text {de }} \mathrm{S} \mathrm{kg}^{-1}$. Em relação ao magnésio, notou-se que as concentrações foliares em todos os materiais genéticos estavam muito acima da faixa considerada adequada (1,6 a 2,0 $\mathrm{g}_{\text {de }} \mathrm{Mg} \mathrm{kg}^{-1}$ ).

De maneira geral, a concentração dos macronutrientes nas mudas apresentaram a seguinte ordem: folhas $>$ raizes $>$ caule + ramos para o nitrogênio; caule + ramos $>$ folhas $\geq$ raizes para fósforo; folhas $>$ caule + ramos $>$ raizes para potássio; folhas $>$ raizes $\geq$ caule + ramos para cálcio; raizes $>$ folhas $>$ caule + ramos para magnésio e raizes $\geq$ folhas $>$ caule + ramos para enxofre. Os resultados obtidos por Silveira et al. (1995a) e Camargo (1997), em relação a concentração dos macronutrientes, nas diferentes partes da planta foram semelhantes aos encontrados para nitrogênio, cálcio, magnésio e enxofre no presente estudo. No entanto, discordantes para o fósforo, uma vez que Silveira et al. (1995a) encontraram as maiores concentrações de fósforo nas raizes. Para o potássio, Silveira et al. (1995a) e Camargo (1997) notaram pequenas variações nas concentrações entre as partes da planta, enquanto os resultados obtidos mostraram que as raizes tinham praticamente a metade da concentração dos outros órgãos (Tabela 11).

Os materiais genéticos apresentaram elevadas concentrações de magnésio

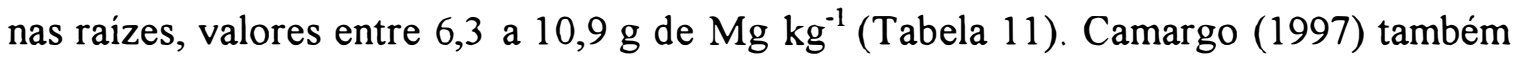
encontrou altas concentrações desse macronutriente nas raizes de clones de Eucalyptus (13,9 a 21,3 $\mathrm{g}$ de $\mathrm{Mg} \mathrm{kg}^{-1}$ ). A explicação para o elevado teor de $\mathrm{Mg}$ poderia ser a presença de vermiculita (20 a $28 \% \mathrm{MgO}$, segundo Fassbender, 1980) em grandes quantidades no substrato utilizado na produção de mudas. 
As concentrações foliares de boro variaram de 34 a $50 \mathrm{mg} \mathrm{kg}^{-1}$ em função dos materiais genéticos (Tabela 12). Esses valores situam-se dentro ou próximo da faixa considerada adequada por Malavolta et al. (1987), a qual está compreendida entre 40 e $50 \mathrm{mg}$ de $\mathrm{B} \mathrm{kg}{ }^{-1}$. Os valores obtidos de 3 a $4 \mathrm{mg}$ de $\mathrm{Cu} \mathrm{kg}^{-1}$ situavam-se na faixa considerada deficiente por Malavolta (1987), que considera teores adequados para o desenvolvimento do Eucalyptus entre 8 a $10 \mathrm{mg}$ de $\mathrm{Cu} \mathrm{kg}{ }^{-1}$. Para corrigir esta deficiência, 15 dias após o plantio das mudas, realizou-se uma pulverização foliar com $1,5 \mathrm{~g}$ de sulfato de cobre/ $\mathrm{L} \mathrm{H}_{2} \mathrm{O}$.

As concentrações foliares de ferro estavam acima das consideradas adequadas (150 a $200 \mathrm{mg} \mathrm{Fe} \mathrm{kg}^{-1}$ ), segundo Malavolta (1987) e Dell et al. (1995). As concentrações de Fe nas raízes estavam em torno de 10 vezes maior que as encontradas por Silveira et al. (1995b) em mudas de E. grandis com 97 dias (Tabela 12). A explicação seria o uso de vermiculita, que contém de 3 a $12 \%$ de $\mathrm{Fe}_{2} \mathrm{O}_{3}$ (Fassbender, 1980), na composição do substrato.

As concentrações foliares de $\mathrm{Mn}$ encontravam-se dentro da faixa estabelecida como adequada por Malavolta (1987) e Dell et al. (1995), as quais variam de 500 a $600 \mathrm{mg}$ de $\mathrm{Mn} \mathrm{kg}^{-1}$ para o gênero Eucalyptus e 193 a $547 \mathrm{mg}$ de $\mathrm{Mn} \mathrm{kg}^{-1}$ para E. grandis, respectivamente (Tabela 12). Em relação ao zinco, as concentrações foliares foram consideradas adequadas com base em Dell et al. (1995), que consideram valores de suficiência entre 17 e $42 \mathrm{mg}$ de $\mathrm{Zn} \mathrm{kg}^{-1}$.

De maneira geral, a concentração dos micronutrientes obedeceu a seguinte ordem: raizes $\geq$ folhas $>$ caule + ramos para o boro; raizes $>$ caule + ramos $\geq$ folhas para o cobre; raizes $>$ folhas $>$ ramos para o ferro e o zinco e folhas $>$ raízes $>$ caule + ramos para o manganês. 
Tabela 11. Concentração dos macronutrientes nas mudas das progênies de Eucalyptus grandis, produzidas em tubetes, com 110 dias de idade.

\begin{tabular}{|c|c|c|c|c|c|}
\hline \multirow{2}{*}{$\begin{array}{l}\text { Nutrientes } \\
\left(\mathrm{g} \mathrm{kg}^{-1}\right)\end{array}$} & \multirow[t]{2}{*}{ Parte da planta } & \multicolumn{4}{|c|}{ Materiais genéticos } \\
\hline & & Progênie 1 & Progênie 2 & Progênie 3 & Progênie 4 \\
\hline \multirow[t]{3}{*}{ Nitrogênio } & Folhas & 12,6 & 17,0 & 9,0 & 12,3 \\
\hline & Caule + Ramos & 3,4 & 4,5 & 2,6 & 3,3 \\
\hline & Raízes & 8.5 & 8,3 & 7,9 & 7,5 \\
\hline \multirow{3}{*}{ Fósforo } & Folhas & 1,8 & 1,8 & 2,0 & 2,4 \\
\hline & Caule + Ramos & 3,2 & 3,8 & 3,8 & 4,0 \\
\hline & Raízes & 1,5 & 1,8 & 1,6 & 2,1 \\
\hline \multirow[t]{3}{*}{ Potássio } & Folhas & 9,8 & 10,4 & 10,4 & 11,8 \\
\hline & Caule + Ramos & 8,7 & 10,5 & 9,6 & 9,4 \\
\hline & Raízes & 5.0 & 5,0 & 5,2 & 6,2 \\
\hline \multirow[t]{3}{*}{ Cálcio } & Folhas & 4,8 & 5,0 & 5,8 & 5,5 \\
\hline & Caule + Ramos & 2,9 & 3,6 & 3.9 & 3,4 \\
\hline & Raízes & 3,9 & 3,9 & 3,7 & 3,8 \\
\hline \multirow[t]{3}{*}{ Magnésio } & Folhas & 4,6 & 5,1 & 6,0 & 4,8 \\
\hline & Caule + Ramos & 0,8 & 1,5 & 1,4 & 1,1 \\
\hline & Raízes & 6,3 & 10,9 & 7,2 & 9,8 \\
\hline \multirow[t]{3}{*}{ Enxofre } & Folhas & 1,5 & 1,8 & 1,6 & 1,6 \\
\hline & Caule + Ramos & 0,7 & 0,9 & 0,8 & 0,7 \\
\hline & Raizes & 1.8 & 2,2 & 1.6 & 2.1 \\
\hline
\end{tabular}

Tabela 12. Concentração dos micronutrientes nas mudas das progênies de Eucalyptus grandis, produzidas em tubetes, com 110 dias de idade.

\begin{tabular}{ll|rrrr}
\hline \hline $\begin{array}{l}\text { Nutrientes } \\
\left(\mathrm{mg} \mathrm{kg}^{-1}\right)\end{array}$ & Parte da planta & \multicolumn{4}{|c}{ Materiais genéticos } \\
\hline Boro & Progênie 1 & Progênie 2 & Progênie 3 & Progênie 4 \\
& Caule + Ramos & 34 & 46 & 50 & 36 \\
& Raizes & 28 & 33 & 27 & 28 \\
& Folhas & 4 & 52 & 48 & 59 \\
\hline Cobre & Caule + Ramos & 3 & 3 & 3 & 3 \\
& Raízes & 13 & 4 & 3 & 3 \\
& Folhas & 443 & 609 & 680 & 16 \\
\hline Ferro & Caule + Ramos & 197 & 228 & 201 & 305 \\
& Raízes & 3624 & 5121 & 2708 & 4009 \\
\hline Manganês & Folhas & 294 & 350 & 351 & 310 \\
& Caule + Ramos & 104 & 114 & 87 & 99 \\
& Raízes & 205 & 320 & 287 & 262 \\
\hline Zinco & Folhas & 29 & 29 & 34 & 37 \\
& Caule + Ramos & 28 & 26 & 25 & 25 \\
& Raízes & 182 & 246 & 134 & 239 \\
\hline \hline
\end{tabular}




\subsection{Sintomas visuais}

\subsubsection{Deficiência de potássio}

Os primeiros sintomas de deficiência de potássio surgiram em torno de 120 dias após o cultivo das plantas na dose de $19,5 \mathrm{mg} \mathrm{de} \mathrm{K} \mathrm{L}^{-1}$ (90 dias) e $0 \mathrm{mg} \mathrm{de} \mathrm{K} \mathrm{L}^{-1}$ (30 dias). Foram caracterizados por pequenas manchas cloróticas entre as nervuras e espalhadas por todo o limbo das folhas mais velhas, porém, com maior concentração das manchas nas margens e na parte superior das folhas. Com a progressão dos sintomas, as manchas se expandiram dando origem a faixas cloróticas ou avermelhadas nas margens das folhas velhas (Figura 4). Posteriormente, ocorreu necrose das manchas e nervuras. No estágio final, verificou-se que nos ramos situados no terço inferior da copa, esses sintomas se manifestaram em todas folhas, porém, com maior intensidade nas folhas mais velhas (Figura 4)

A intensidade dos sintomas diferiu entre as progênies, somente na fase inicial. Após 120 dias de cultivo das plantas sob baixa/ausência de potássio na solução nutritiva, as progênies 2 e 3 apresentavam 60 e $80 \%$ das árvores com sintomas de deficiência bem definidos, enquanto que nas progênies 1 e 4, somente 20 e $40 \%$ das árvores. No final do experimento, as diferenças visuais em relação a intensidade dos sintomas, entre as progênies, não foram tão evidentes.

Os sintomas observados no presente estudo assemelham-se aos descritos por (Will, 1961; Kaul et al., 1966, 1968, 1970a e 1970b; Rocha Filho et al., 1978; Dell et al., 1995; Silveira et al.,1996 e Silveira et al., 1999). Porém, não foi constatado aumento das brotações laterais conforme verificados por Kaul et al. (1966) e Rocha Filho et al. (1978). 
Progênie 1

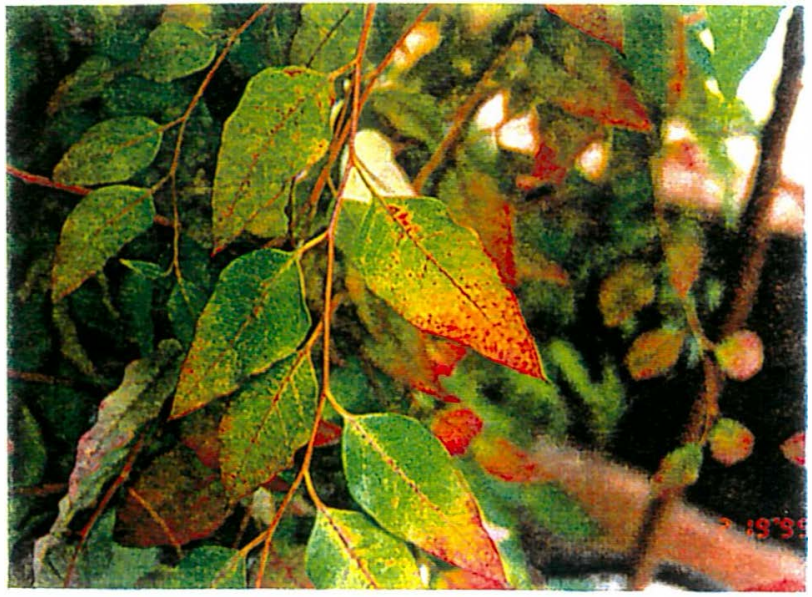

Progênic 3

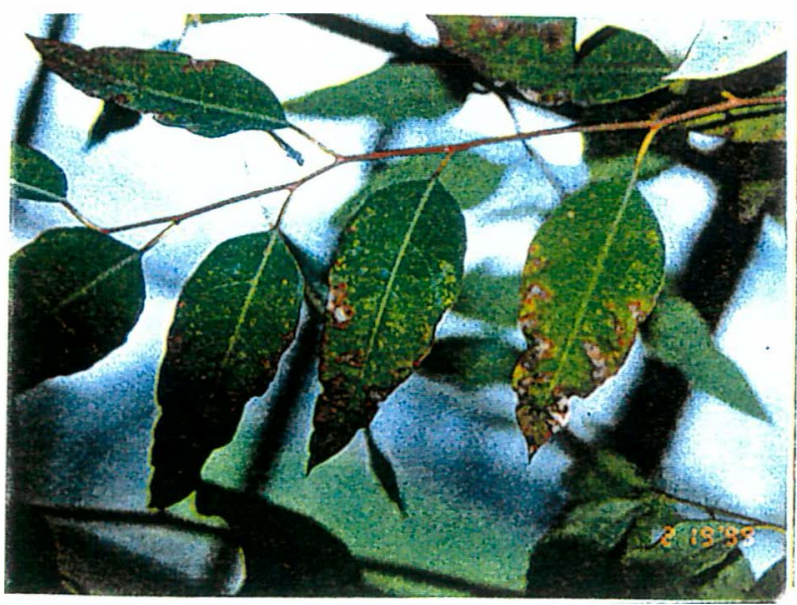

Progênie 2

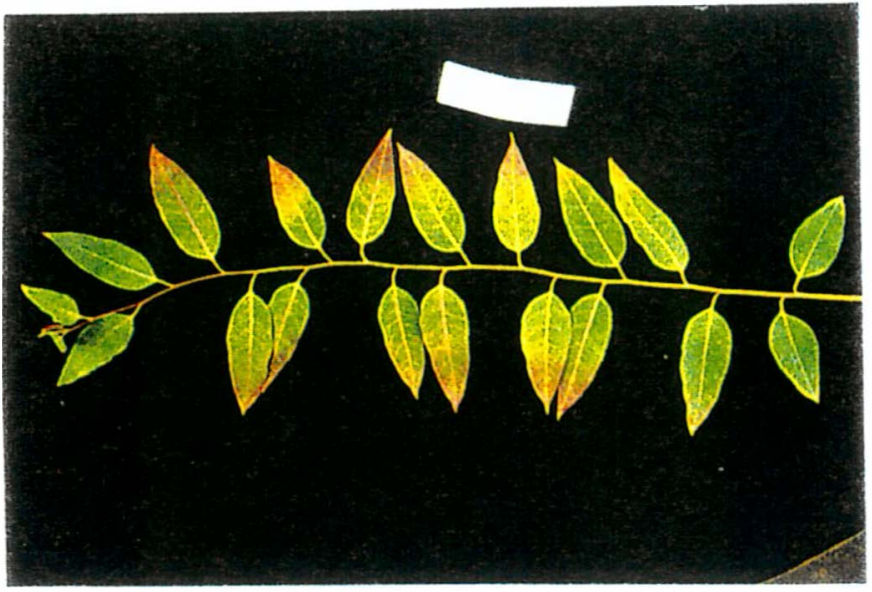

Progênic 4

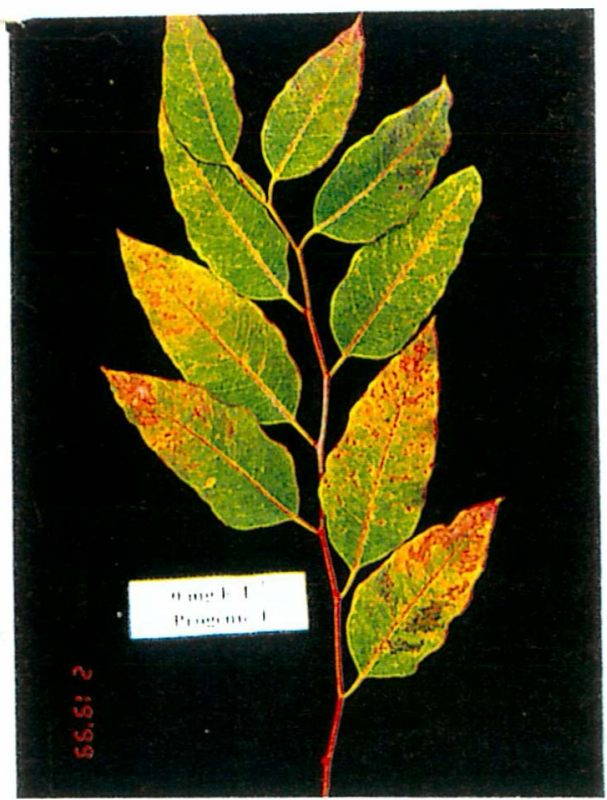

Figura 4. Sintomas de deficiência de potássio nas folhas das progênies de Eucalyphus grandis, quando cultivadas na ausência de potássio. 


\subsubsection{Clorose das folhas na dose de $526,5 \mathrm{mg} \mathrm{de} \mathrm{K} \mathrm{L}^{-1}$}

Na dose de $526,5 \mathrm{mg}$ de $\mathrm{K} \mathrm{L}^{-1}$ verificou-se uma clorose generalizada das folhas novas e das folhas diagnóstico (Figura 5), após 3 meses de cultivo. As cloroses foram mais intensas nas progênies 3 e 4 . Esses sintomas assemelham-se com a carência de enxofre descrita por Dell et al. (1995) e Silveira et al. (1996). Neste tratamento, cerca de $55 \%$ do potássio foi fornecido na forma de cloreto de potássio, o que equivale ao fornecimento de $266,2 \mathrm{mg}$ de $\mathrm{Cl} \mathrm{L}^{-1}$. A explicação para os sintomas de deficiência de enxofre foi que as altas doses de cloreto inibiram a absorção de sulfato, resultando em concentrações deficientes nas folhas (conforme será discutido no item 4.4.2).

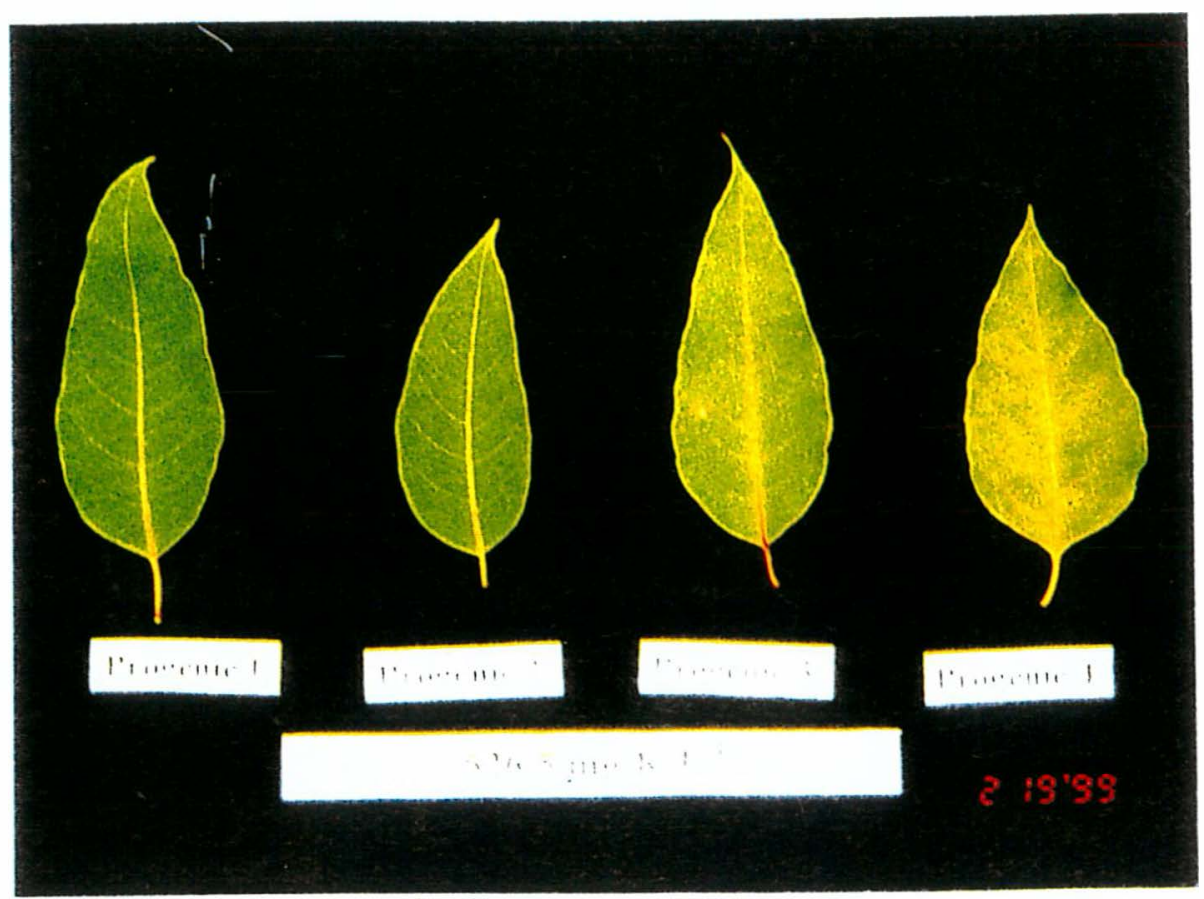

Figura 5. Clorose generalizada das folhas recém maduras das progênies de Eucalyptus grandis, quando cultivadas na dose de $526,5 \mathrm{mg}^{\mathrm{dc}} \mathrm{K} \mathrm{L}^{-1}$. 


\subsection{Desenvolvimento das plantas}

\subsubsection{Altura}

Não houve efeito das doses de $\mathrm{K}$ e da interação dose de $\mathrm{K} \times$ progênie na altura das plantas. Porém, constatou-se diferença entre as progênies 3 e 2 , sendo que a progênie 3 apresentou uma superioridade de $10 \%$ em altura em relação a progênie 2 , não havendo diferença desta para as progênies 1 e 4 (Figura 6). Tais resultados estão de acordo com os obtidos por Sgarbi et al. (1997), que observaram que plantas de E. grandis $\mathrm{x}$ E. urophylla supridas inicialmente com potássio (0-9 meses de idade) e depois submetidas a omissão (10-26 meses) não apresentavam diferenças em altura quando comparadas com aquelas que receberam potássio durante todo o período de crescimento (0-26 meses). Resultados semelhantes também foram constatados por Novais et al. (1980), que não encontraram tendência de aumento na altura de mudas de E. grandis com 100 dias de idade, com o aumento do nível de potássio disponível no solo.

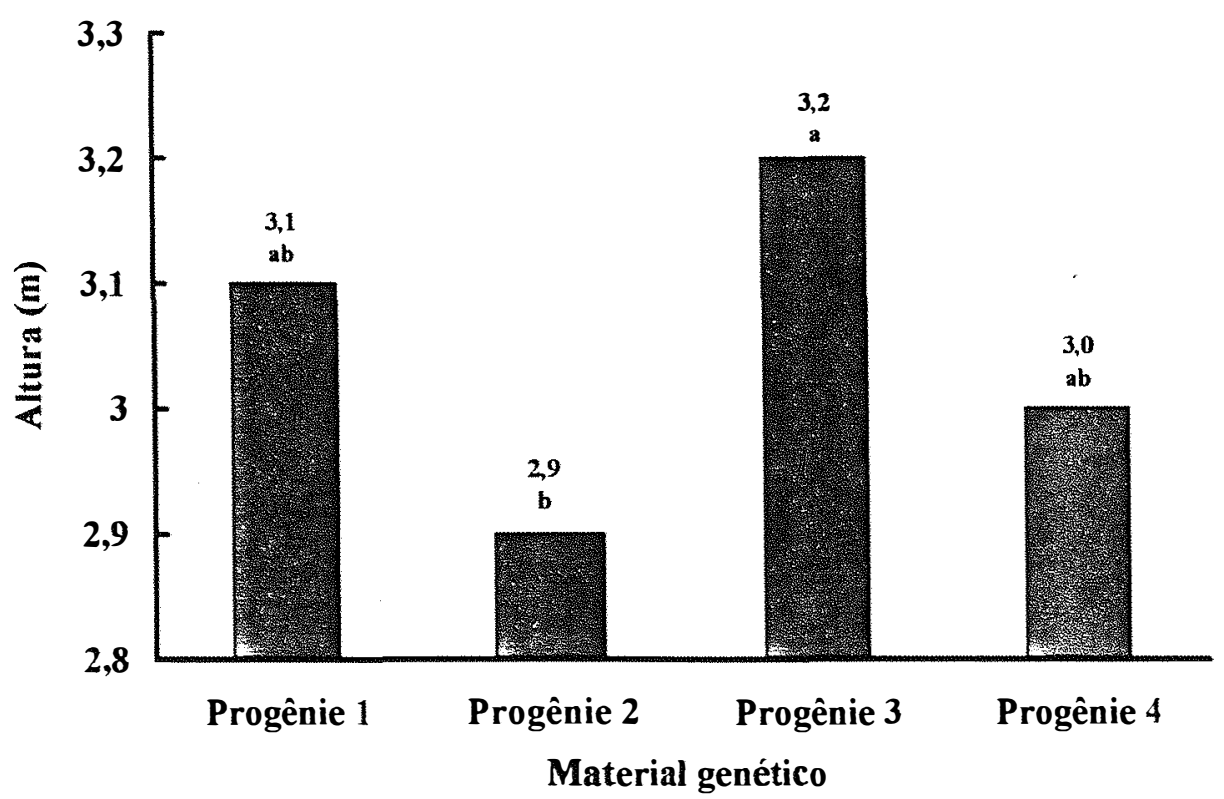

Figura 6. Média de altura das progênies de Eucalyptus grandis (letras seguidas da mesma latra nāo diferem entre si pelo teste Tukey a o nivel de $5 \%$ de probabilidade). 


\subsubsection{Diâmetro}

Houve diferença entre as doses de potássio para o diâmetro basal das plantas, independente do material genético (Tabela 13). Os maiores diâmetros foram observados nas doses de 58,5 e $175,5 \mathrm{mg}$ de $\mathrm{K} \mathrm{L}^{-1}$, não havendo diferença entre essas duas doses. $\mathrm{Na}$ ausência e na dose mais elevada houve redução de aproximadamente $7 \%$ no diâmetro em relação as doses de 58,5 e $175,5 \mathrm{mg}$ de $\mathrm{K} \mathrm{L} \mathrm{L}^{-1}$. Houve interação entre as doses de potássio e os materiais genéticos, sendo que na ausência de potássio ocorreram diferenças significativas entre as progênies. A progênie 2 apresentou menor diâmetro na falta de potássio em relação as demais, porém, diferindo estatisticamente somente da progênie 4.

Tabela 13. Diâmetro basal das progênies de Eucalyptus grandis nas diferentes doses de potássio na solução nutritiva.

\begin{tabular}{|c|c|c|c|c|c|}
\hline \multirow{2}{*}{$\begin{array}{l}\text { Material } \\
\text { genético }\end{array}$} & \multicolumn{5}{|c|}{ K na solução $\left(\mathrm{mg} \mathrm{L}^{-1}\right)$} \\
\hline & 0 & 58,5 & 175,5 & 526,5 & Média \\
\hline & \multicolumn{5}{|c|}{$\mathrm{mm}$} \\
\hline Progênie I & 23,8 ab A & 26,1 a $A$ & 25,0 a $\mathrm{A}$ & 24,7 a $A$ & $24,9 \mathrm{a}$ \\
\hline Progênie 2 & 22,7 b B & 25,1 a $\mathrm{A}$ & 25,5 a A & 23,7 a B & 24,2 a \\
\hline Progênie 3 & 24,4 ab $A B$ & 26,2 a $A B$ & 26,7 a $A$ & 23,6 a $B$ & $25,2 \mathrm{a}$ \\
\hline Progênie 4 & 25,3 a $\mathrm{A}$ & 25,2 a $\mathrm{A}$ & 25,6 a $\mathrm{A}$ & 23,8 a B & $25,0 \mathrm{a}$ \\
\hline Média & $24,0 \mathrm{~B}$ & $25,6 \mathrm{~A}$ & $25,7 \mathrm{~A}$ & $23,9 \mathrm{~B}$ & \\
\hline
\end{tabular}

Dentre os materiais genético estudados, observou-se relações quadráticas entre o diâmetro basal e as dose de potássio para as progênies 2,3 e 4, enquanto que não houve relação significativa para a progênie 1 (Tabela 14). Nas progênies que responderam à adição de potássio, nota-se comportamentos bastante similares nas progênies 2 e 3 em comparação com a progênie 4 . O nível de potássio na solução para a máxima produção da progênie 4 foi de $50 \mathrm{mg}$ de $\mathrm{K} \mathrm{L}^{-1}$, sendo que para a progênie 2 e 3 
foi de $275 \mathrm{mg}$ de $\mathrm{K} \mathrm{L}^{-1}$ e $250 \mathrm{mg}$ de $\mathrm{K} \mathrm{L}^{-1}$, respectivamente. Esses resultados confirmam as diferenças de respostas observadas para tais materiais genéticos em relação à aplicação de $\mathrm{K}$, em condições de campo na região de Itatinga $/ \mathrm{SP}^{1}$, onde a progênie 1 e 4 não foram tão responsivas à aplicação de $\mathrm{K}$.

Tabela 14. Equações de regressões para o diâmetro da região basal do caule das progênies de Eucalyptus grandis em função das doses de potássio na solução nutritiva.

\begin{tabular}{lcccc}
\hline \hline $\begin{array}{l}\text { Material } \\
\text { genético }\end{array}$ & Equação & $\begin{array}{c}\text { Máxima } \\
\text { produção } \\
(\mathrm{mm})\end{array}$ & $\begin{array}{c}\mathrm{K} \text { para máxima } \\
\text { produção } \\
\left(\mathrm{mg} \mathrm{L}^{-1}\right)\end{array}$ \\
\hline $\begin{array}{l}\text { Progênie 1 } \\
\text { Progênie 2 }\end{array}$ & $\mathrm{y}=23,1753+0,022 \mathrm{x}-0,00004 \mathrm{x}^{2}$ & $\mathrm{R}^{2}=0,58^{* *}$ & 26,2 & \\
Progênie 3 & $\mathrm{y}=24,6587+0,020 \mathrm{x}-0,00004 \mathrm{x}^{2}$ & $\mathrm{R}^{2}=0,49^{* *}$ & 27,1 & 250 \\
Progênie 4 & $\mathrm{y}=25,1941+0,004 \mathrm{x}-0,00001 \mathrm{x}^{2}$ & $\mathrm{R}^{2}=0,53^{* *}$ & 25,4 & 50 \\
\hline \hline
\end{tabular}

Os efeitos da idade da planta no crescimento em diâmetro basal foram lineares, independente da dose de potássio aplicada, mostrando que mesmo na ausência de $\mathrm{K}$ não houve estabilização do crescimento (Figura 7 ). Observa-se ainda que as diferenças entre as doses de potássio para o diâmetro começaram a ficar mais nítidas a partir de 6 meses de cultivo.

\footnotetext{
${ }^{1}$ Comunicação pessoal do Engenheiro Shinitiro Oda da Companhia Suzano de Papel e Celulose.
} 
Progênie 1

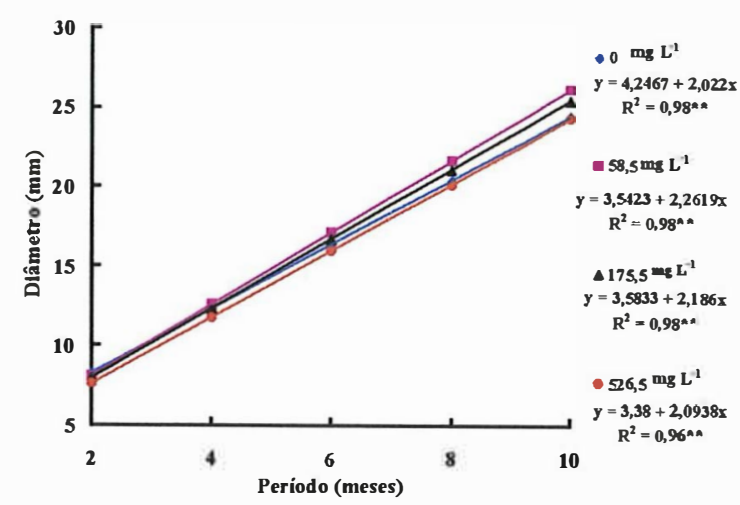

Progênie 3

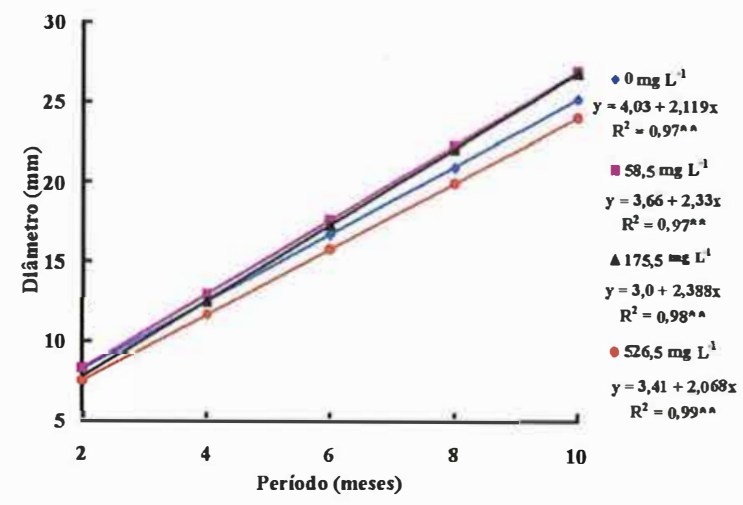

Progênie 2

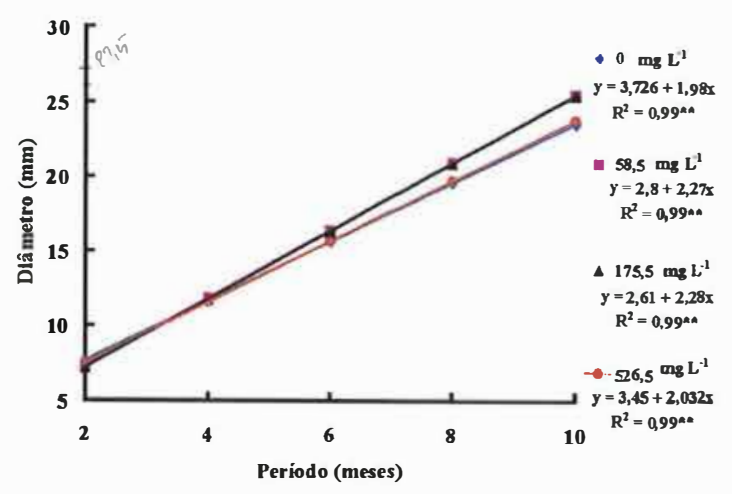

Progênie 4

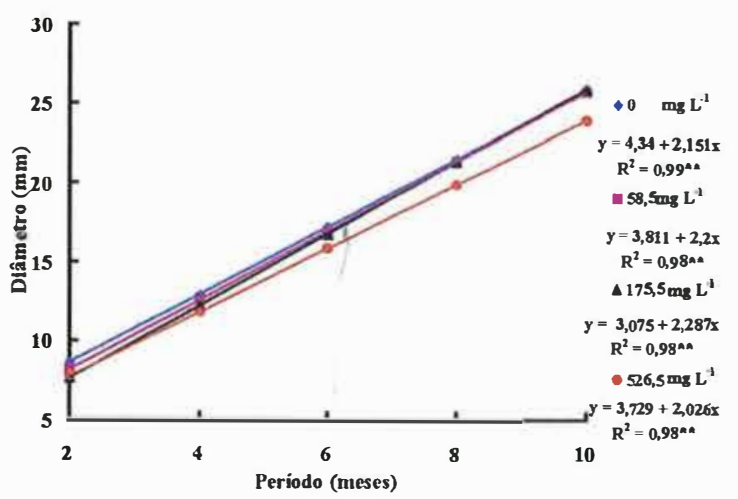

Figura 7. Diâmetro da região basal do caule das progênies de Eucalyptus grandis em função do período de cultivo nas diferentes doses de potássio na solução nutritiva.

\subsubsection{Produção de matéria seca}

As correlações entre a produção de matéria seca total e a produção de matéria seca das partes da planta mostraram que as progênies 2,3 e 4 tiveram comportamentos semelhantes, ou seja, aumentando-se a matéria seca das folhas, ramos, casca e lenho aumentava-se a matéria seca total (Tabela 15). Na progênie 1, houve correlação positiva entre a matéria seca das folhas, ramos e casca com a total, porém, não houve relação entre a produção de matéria seca de lenho e a matéria seca total. 
Tabela 15. Coeficientes de correlações de Pearson entre a matéria seca total e a matéria seca das partes da planta das progênies de Eucalyptus grandis.

\begin{tabular}{lllll}
\hline \hline Material genético & \multicolumn{4}{c}{ Partes da planta } \\
\cline { 2 - 5 } & Folhas & Ramos & Casca & lenho \\
\hline Progênie 1 & $0,75^{* *}$ & $0,77^{* *}$ & $0,49^{* *}$ & $\mathrm{~ns}$ \\
Progênie 2 & $0,74^{* *}$ & $0,76^{* *}$ & $0,78^{* *}$ & $0,70^{* *}$ \\
Progênie 3 & $0,88^{* *}$ & $0,82^{* *}$ & $0,94^{* *}$ & $0,94^{* *}$ \\
Progênie 4 & $0,75^{* *}$ & $0,51^{* *}$ & $0,67^{* *}$ & $0,89^{* *}$ \\
\hline \hline
\end{tabular}

Em relação a produção de folhas, independente da progênie, verificou-se que houve redução de $25 \%$ na biomassa foliar na dose de $526,5 \mathrm{mg}$ de $\mathrm{K} \mathrm{L}^{-1}$ quando comparada a dose de $175,5 \mathrm{mg} \mathrm{L}^{-1}$ (Tabela 16). Os materiais genéticos responderam de maneira diferenciada em termos de produção de folhas. A progênie 3 foi menos produtiva quando comparada com as progênies 2 e 4 . Houve interação entre as doses de potássio e os materiais genéticos. $\mathrm{Na}$ ausência de $\mathrm{K}$, observou-se uma menor produção de folhas para progênie 3 em relação as demais, mesma tendência foi observada para a dose de $58,5 \mathrm{mg} \mathrm{L}^{-1}$. Na dose de $175,5 \mathrm{mg} \mathrm{L}^{-1}$, não houve diferença significativa entre as progênies, enquanto que na dose mais elevada houve redução drástica na produção de folhas da progênie 1. A maior produção de folhas foi encontrada nas plantas cultivadas na ausência de potássio para a progênie $1,58,5 \mathrm{mg}$ de $\mathrm{K} \mathrm{L}^{-1}$ para a progênie 2 e 175,5 $\mathrm{mg} \mathrm{L}^{-1}$ para as progênies 3 e 4 .

$\mathrm{Na}$ produção de matéria seca dos ramos, constatou-se diferença significativa entre os materiais genéticos, sendo que a progênie 3 foi a que apresentou a menor produção (Tabela 16). Considerando todas as progênies, observou-se que a dose mais elevada de potássio chegou a reduzir mais a produção de ramos quando comparada com a sua ausência na solução. As maiores produções foram obtidas com a dose de $175,5 \mathrm{mg}$ $\mathrm{L}^{-1}$. Houve interação entre as doses e as progênies. Tanto na ausência como na dose de $58,5 \mathrm{mg}$ de $\mathrm{K} \mathrm{L}^{-1}$, as menores produções ocorreram na progênie 3 quando comparadas com as demais. As progênies não diferiram quando foram cultivadas em 175,5 mg de K $\mathrm{L}^{-1}$. Na dose mais alta de potássio, as progênies 3 e 4 apresentaram menor produção de ramos em relação as progênies 1 e 2 . 
A progênie 3 foi a que apresentou maior produção de casca e lenho (Tabela 16). Sem levar em consideração os materiais genéticos, verificou-se que a maior produção de casca e lenho foi encontrada nas plantas cultivadas na dose de $175,5 \mathrm{mg} \mathrm{L}^{-1}$. Houve interação entre as doses e as progênies tanto para a MS de casca como de lenho. Para a casca, não houve diferença significativa entre os materiais genéticos na presença de 58,5 mg de $\mathrm{K} \mathrm{L}^{-1}$, e no lenho, na ausência de potássio. Tanto na dose de 58,5 como na de $175,5 \mathrm{mg} \mathrm{L}^{-1}$, a progênie 3 mostrou-se superior as demais. Não houve diferença entre os materiais genéticos para a produção de lenho na falta de potássio. $\mathrm{Na}$ ausência de $\mathrm{K}$, a progênie 2 foi menos produtiva em termos de MS de casca, enquanto que na dose de $526,5 \mathrm{mg} \mathrm{L}^{-1}$, foi a progênie 4 .

Apesar de haver diferença significativa entre os materiais genéticos para a produção de MS das várias partes da planta, o mesmo não foi verificado quanto considerou-se a produção de MS total (Tabela 17). Sem levar em consideração o material genético utilizado, as maiores produções ocorreram nas doses de 58,5 e 175,5 $\mathrm{mg}$ de $\mathrm{K} \mathrm{L}^{-1}$ (Tabela 17). Houve interação entre as doses e as progênies, sendo que na falta de potássio, as progênies 2 e 3 apresentaram menores produções quando comparadas com as progênies 1 e 4 . Nas demais doses de potássio, não houve diferença significativa entre os genótipos.

A Tabela 18 mostra a porcentagem de cada parte da planta na produção de MS total, nota-se que a progênie 3 teve um comportamento diferenciado, apresentando maior participação do lenho na produção da MS total (37\% do total) quando comparada as demais. Esta progênie também apresentou menor porcentagem de folhas em relação ao acúmulo total de MS. Considerando que os principais produtos florestais são a madeira serrada e a celulose para produção de papel, a progênie 3 poderia ser a mais interessante, do ponto de vista do melhoramento, devido a sua maior eficiência na produção de lenho em relação a MS total. No entanto, esses resultados são referentes a fase juvenil de crescimento, existindo a necessidade de estudos em condições de campo até a idade de corte ( 7 anos para celulose e $>15$ anos para madeira serrada) para verificar a correlação entre a fase juvenil e a adulta. 
Tabela 16. Matéria seca das folhas, ramos, casca e lenho das progênies de Eucalyptus grandis nas diferentes doses de potássio na solução nutritiva.

\begin{tabular}{|c|c|c|c|c|c|}
\hline \multirow{2}{*}{$\begin{array}{l}\text { Material } \\
\text { genético }\end{array}$} & \multicolumn{4}{|c|}{$\mathrm{K}$ na solução $\left(\mathrm{mg} \mathrm{L}^{-1}\right)$} & \multirow[b]{2}{*}{ Média } \\
\hline & 0 & 58,5 & 175,5 & 526,5 & \\
\hline & \multicolumn{5}{|c|}{ Folhas (g/planta) } \\
\hline Progênie l & $171 \mathrm{aA}(166)^{1}$ & $145 \mathrm{ab} \mathrm{A} \mathrm{(141)}$ & 150 a A (146) & $103 \mathrm{bB}(100)$ & $142 a b(114)^{2}$ \\
\hline Progênie 2 & 142 a A (101) & 172 a A (123) & 155 a A (111) & 140 a A (100) & $152 \mathrm{a}(122)$ \\
\hline Progênie 3 & 111 b C (100) & 130 b B (117) & 143 a A (129) & $117 \mathrm{ab} B C(105)$ & $125 \mathrm{~b}(100)$ \\
\hline Progênie 4 & 147 a $\mathrm{AB}(109)$ & $152 \mathrm{ab} \mathrm{AB}(112)$ & 171 a A (126) & 135 a B (100) & $151 \mathrm{a}(121)$ \\
\hline \multirow[t]{2}{*}{ Média } & $143 \mathrm{~A}(115)^{3}$ & $150 \mathrm{~A}(121)$ & $155 \mathrm{~A}(125)$ & $124 \mathrm{~B}(100)$ & \\
\hline & \multicolumn{5}{|c|}{ Ramos (g/planta) } \\
\hline Progênie l & 98 a $A(111)$ & 100 a A (114) & 97 a $\mathrm{AB}(110)$ & 88 a B (100) & $96 \mathrm{a}(117))$ \\
\hline Progênie 2 & 87 ab B (100) & 94 ab A (108) & 96 a A (110) & 90 a $\mathrm{AB}(103)$ & $92 \mathrm{ab}(112)$ \\
\hline Progênie 3 & $78 \mathrm{bBC}(111)$ & $85 \mathrm{~b} \mathrm{AB}(121)$ & 94 a A (134) & 70 b C (100) & $82 \mathrm{c}(100)$ \\
\hline Progênie 4 & $89 \mathrm{ab} A(117)$ & 90 ab A (118) & 92 a A (120) & 76 b B (100) & 87 bc (106) \\
\hline \multirow[t]{2}{*}{ Média } & 88 B (109) & $92 \mathrm{AB}(114)$ & $95 \mathrm{~A}(117)$ & $81 \mathrm{C}(100)$ & \\
\hline & \multicolumn{5}{|c|}{ Casca (g/planta) } \\
\hline Progênie l & 66 a A (100) & 67 a $A(101)$ & 76 a A (115) & 66 a $A(100)$ & $69 \mathrm{ab}(114)$ \\
\hline Progênie 2 & 55 b C (100) & 67 a $\mathrm{AB}(122)$ & 75 a $A(136)$ & $62 \mathrm{ab} B C(113)$ & $65 \mathrm{bc}(107)$ \\
\hline Progênie 3 & 65 a B (100) & 74 a A (114) & 76 a A (117) & 68 a B (105) & $71 \mathrm{a}(117)$ \\
\hline Progênie 4 & $61 \mathrm{ab} A B(115)$ & 67 a $A(126)$ & $60 \mathrm{~b} \mathrm{AB}(113)$ & 53 b B (100) & $60 \mathrm{a}(100)$ \\
\hline \multirow[t]{2}{*}{ Média } & $62 \mathrm{~B}(100)$ & $69 \mathrm{~A}(111)$ & $72 \mathrm{~A}(116)$ & $62 \mathrm{~B}(100)$ & \\
\hline & \multicolumn{5}{|c|}{ Lenho (g/planta) } \\
\hline Progênie l & 128 a A (100) & 133 b A (104) & 139 b A (108) & $148 \mathrm{ab} \mathrm{A}(116)$ & $137 \mathrm{~b}(101)$ \\
\hline Progênie 2 & 124 a B (100) & 139 b AB (112) & 154 b A (124) & $125 \mathrm{ab} B(101)$ & $135 \mathrm{~b}(100)$ \\
\hline Progênie 3 & 131 a C (100) & 179 a $\mathrm{AB}(137)$ & 191 a A (146) & 154 a BC (117) & $164 a(121)$ \\
\hline Progênie 4 & 152 a $\mathrm{AB}(126)$ & $161 \mathrm{ab} A(133)$ & $161 \mathrm{~b} \mathrm{~A}(133)$ & $121 \mathrm{bB}(100)$ & 149 a (110) \\
\hline Média & $134 \mathrm{C}(100)$ & $153 \mathrm{AB}(117)$ & $161 \mathrm{~A}(120)$ & $137 \mathrm{BC}(102)$ & \\
\hline
\end{tabular}

Médias seguidas de mesma lâra não diferem entre si (minúscula na vertical e maiúscula na horizontal) pelo teste de Tukey ao nivel de $5 \%$ de probabilidade; 1 - percentual em relação a menor produção de matéria seca para a dose de potássio dentro do fator progènie, 2 - percentual em relação a menor produção de matéria seca dentro do fator progènie; 3 - percentual em relação a menor produção de matéria seca dentro do fator dose de potássio.

Tabela. 17. Matéria seca total produzida pelas progênies de Eucalyptus grandis nas diferentes doses de potássio na solução nutritiva.

\begin{tabular}{|c|c|c|c|c|c|}
\hline \multirow[t]{2}{*}{ Material genético } & \multicolumn{4}{|c|}{$\mathrm{K}$ na solução $\left(\mathrm{mg} \mathrm{L}^{-1}\right)$} & \multirow[b]{2}{*}{ Média } \\
\hline & 0 & 58,5 & 175,5 & 526,5 & \\
\hline & \multicolumn{5}{|c|}{$\mathrm{g} /$ planta } \\
\hline Progènie 1 & 463 a A (114) & 445 a $\mathrm{AB}(110)$ & 462 a A (114) & 405 a B (100) & $444 a$ \\
\hline Progènie 2 & 408 b B (100) & +72 a A (116) & 480 a $\mathrm{A}(118)$ & +17 a B (102) & 444 a \\
\hline Progènie 3 & 385 b B (100) & 468 a A (121) & 504 a $\mathrm{A}(131)$ & 409 a B (106) & $442 \mathrm{a}$ \\
\hline Progènie 4 & 449 a A (117) & +70 a A (122) & 484 a A (126) & 385 a B (100) & $447 \mathrm{a}$ \\
\hline Média & $426.7 \mathrm{~B}(105)^{2}$ & $463,2 \mathrm{~A}(114)$ & $483.0 \mathrm{~A}(119)$ & $406,5 \mathrm{~B}(100)$ & \\
\hline
\end{tabular}

Médias seguidas de mesma letra não diferem entre si (minúscula na vertical e maiúscula na horizontal) pelo teste de Tukey ao nível de $5 \%$ de probabilidade; 1 - percentual em relação a menor produção de matéria seca para a dose de potássio dentro do fator progènie, 2 - percentual em relação a menor produção de matéria seca dentro do fator dose de potássio. 
Tabela 18. Porcentagem média de participação da matéria seca de cada parte da planta na produção de matéria seca total das progênies de Eucalyptus grandis.

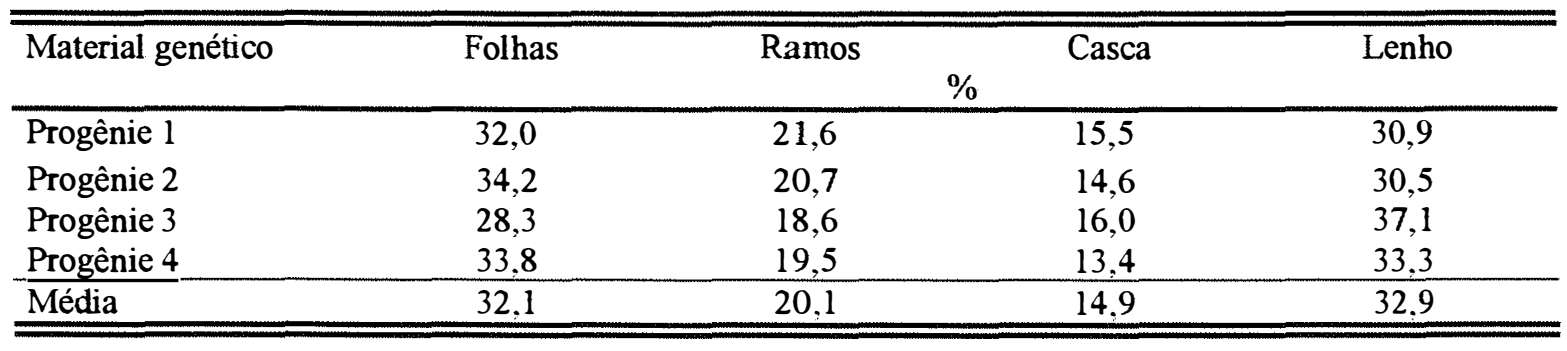

As equações de regressões relacionando as doses de potássio com a produção de MS das folhas, ramos e casca das progênies encontram-se na Tabela 19. As progênies apresentaram diferentes comportamentos, sendo que para a progênie 1 , com o aumento do potássio na solução nutritiva ocorreu queda linear na produção de MS tanto de folhas como de ramos, enquanto que a relação entre a produção de casca e a dose de potássio não foi significativa. As progênies 3 e 4 apresentaram relações quadráticas para a produção de MS de folhas, ramos e casca. Na progênie 4, somente a maior dose de potássio ocasionou decréscimos na produção da MS. Já na progênie 3, as menores produções ocorreram tanto na ausência como na dose de $526,5 \mathrm{mg}$ de $\mathrm{K} \mathrm{L}^{-1}$, mostrando que esse material genético foi mais responsivo à adição de potássio quando comparado com a progênie 4. Efeito similares aos obtidos para a progênie 3 foram encontrados na progênie 2 , exceto para a produção de folhas, em que a relação entre a produção de MS e a dose de $\mathrm{K}$ não foi significativa.

Em relação a produção de lenho, o comportamento apresentado pelas progênies 2 e 3 em relação a dose de $\mathrm{K}$ foi parecido (Figura 8). Pelas equações de regressões estimaram-se as máximas produções de lenho, a qual foi obtida com a dose de 295,5 e $246,5 \mathrm{mg} \mathrm{L}^{-1}$ para as progênies 3 e 2, respectivamente. Esses genótipos diferiram em relação aos ganhos de produtividade, uma vez que a progênie 3 apresentou diferença de $50 \%$ quando comparou-se a máxima produção com a obtida na ausência de potássio, e enquanto a progênie 2 , apenas $24 \%$. Tais resultados obtidos para essas progênies corroboram com os relatados por Barros et al. (1981), Valeri et al. (1991), Galo (1993) e Gava (1996), os quais obtiveram aumentos na produtividade do 
Eucalytpus através da aplicação de potássio, em condições de campo. O único diferencial entre esses resultados e os do presente trabalho está no ganho obtido com a adição de potássio. Os aumentos de produção em volume de madeira alcançados com a adubação potássica variaram de $67 \%$ para E. saligna no cerrado de Minas Gerais no trabalho de Barros et al. (1991) até 118\% para E. grandis no sul do Estado de São Paulo, conforme Gava (1996). Portanto, os aumentos de produtividade nas condições de campo foram maiores que os obtidos para as progênie 2 e 3 neste estudo. A explicação para isto, seria a diferença de idade entre as plantas do presente estudo (fase juvenil - 1 ano de idade) e as dos estudos de campo (5-7anos), sendo que a maior exigência de potássio ocorre na fase adulta do Eucalyptus, ou seja, com o aumento da idade, segundo Barros \& Novais (1990).

Tabela 19. Equações de regressões para a produção de matéria seca das folhas, ramos e casca das progênies de Eucalyptus grandis em função das doses de potássio na solução nutritiva

\begin{tabular}{|c|c|c|c|c|}
\hline $\begin{array}{l}\text { Material } \\
\text { genético }\end{array}$ & Equação & & $\begin{array}{l}\text { Máxima } \\
\text { produção } \\
\text { (g/planta) }\end{array}$ & $\begin{array}{c}\text { K para máxima } \\
\text { produção } \\
\left(\mathrm{mg} \mathrm{L}^{-1}\right)\end{array}$ \\
\hline & \multicolumn{4}{|c|}{ Folhas } \\
\hline Progênie 1 & $y=164,0667-0,115 x$ & $\mathrm{R}^{2}=0,56^{* *}$ & 164 & 0 \\
\hline Progênie 2 & \multicolumn{4}{|c|}{ Não significativo } \\
\hline Progênie 3 & $y=112,8425+0,2640 x-0,0005 x^{2}$ & $\mathrm{R}^{2}=0,68^{* *}$ & 148 & 264 \\
\hline Progênie 4 & $y=114,7090+0,2092 x-0,0004 x^{2}$ & $\mathrm{R}^{2}=0,46^{* *}$ & 172 & 261 \\
\hline \multicolumn{5}{|c|}{ Ramos } \\
\hline Progênie 1 & $y=100,1333-0,0225 x$ & $\mathrm{R}^{2}=0,44^{* *}$ & 100 & 0 \\
\hline Progênie 2 & $y=88,5695+0,0700 x-0,0001 x^{2}$ & $\mathrm{R}^{2}=0,47^{* *}$ & 101 & 350 \\
\hline Progênie 3 & $y=77,8488+0,1430 x-0,0003 x^{2}$ & $\mathrm{R}^{2}=0,68^{* *}$ & 95 & 238 \\
\hline Progênie 4 & $y=88,7745+0,0333 x-0,0001 x^{2}$ & $\mathrm{R}^{2}=0,46^{* *}$ & 91 & 166 \\
\hline \multicolumn{5}{|c|}{ Casca } \\
\hline Progênie 1 & \multicolumn{4}{|c|}{ Não significativo } \\
\hline Progênie 2 & $y=56,6471+0,1509 x-0,00026 x^{2}$ & $\mathrm{R}^{2}=0,60^{* *}$ & 78 & 290 \\
\hline Progênie 3 & $y=66,9274+0,0873 x-0,00016 x^{2}$ & $\mathrm{R}^{2}=0,58^{* *}$ & 79 & 273 \\
\hline Progênie 4 & $y=63,2694+0,0060 x-0,00002 x^{2}$ & $\mathrm{R}^{2}=0.35^{*}$ & 91 & 150 \\
\hline
\end{tabular}


Em termos ainda de produção de MS lenhosa, a progênie 4 não foi considerada responsiva à adição de $\mathrm{K}$ no meio até a dose de $178,7 \mathrm{mg} \mathrm{L}^{-1}$, sendo que acima desse nível, verificou quedas acentuadas na produção (Figura 8). Para a progênie 1, não houve grandes incrementos em MS lenhosa conforme aumentou-se a dose, mostrando que genótipo apresenta alta estabilidade tanto em condições de carência como excesso de potássio.

Em relação a MS total, os efeitos foram semelhantes aos obtidos para a MS lenhosa, com exceção da progênie 1 que apresentou decréscimo de produção com o aumento da dose de potássio.

As produções relativas de matéria seca total e lenhosa em função das doses de potássio são mostradas na Figura 10. Nota-se uma maior resposta da progênie 3 à aplicação de $\mathrm{K}$ em relação as demais.

Progênie 1

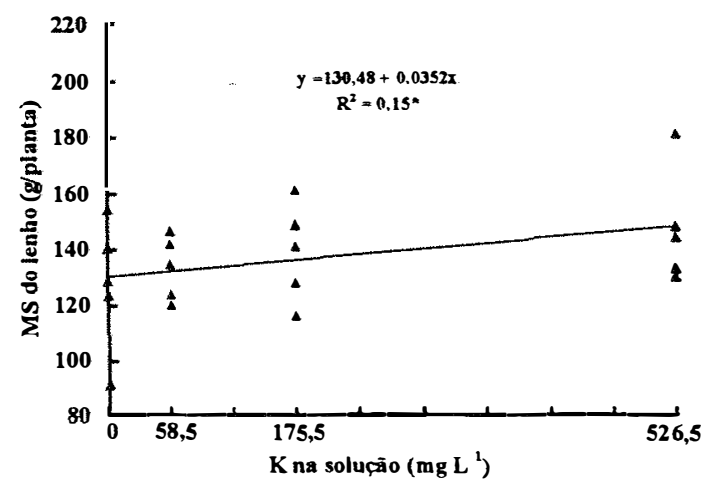

Progênie 3

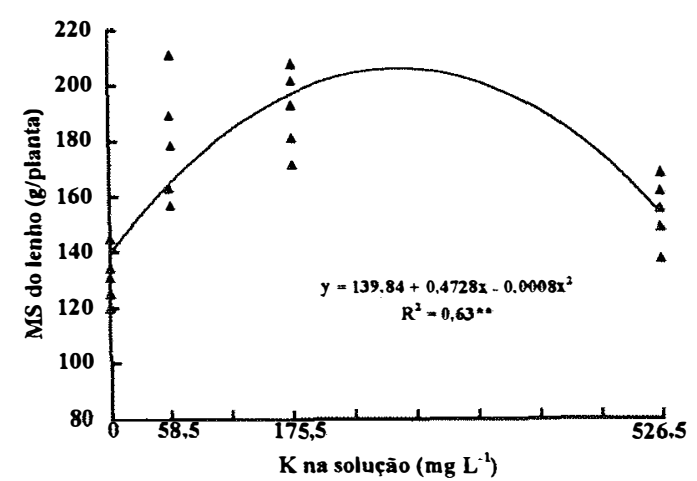

Progênie 2

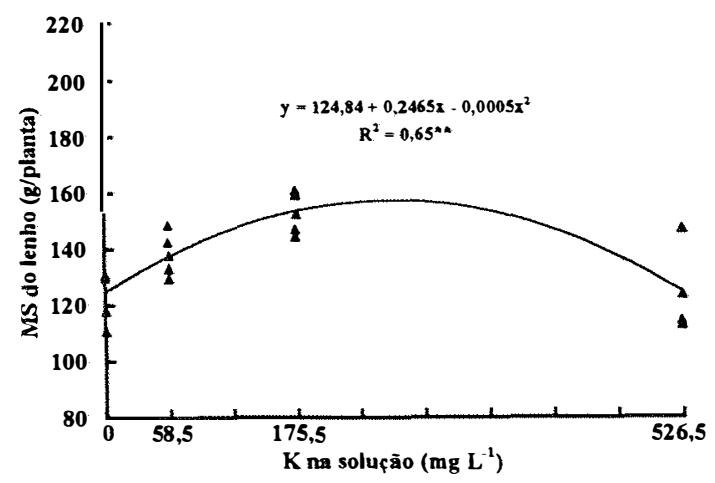

Progênie 4

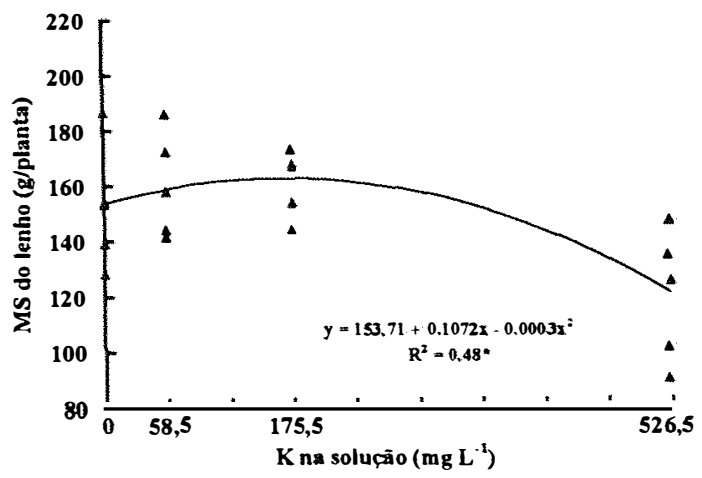

Figura 8. Produção de matéria seca lenhosa das progênies de Eucalyptus grandis em função das doses de potássio na solução nutritiva. 
Progênie 1

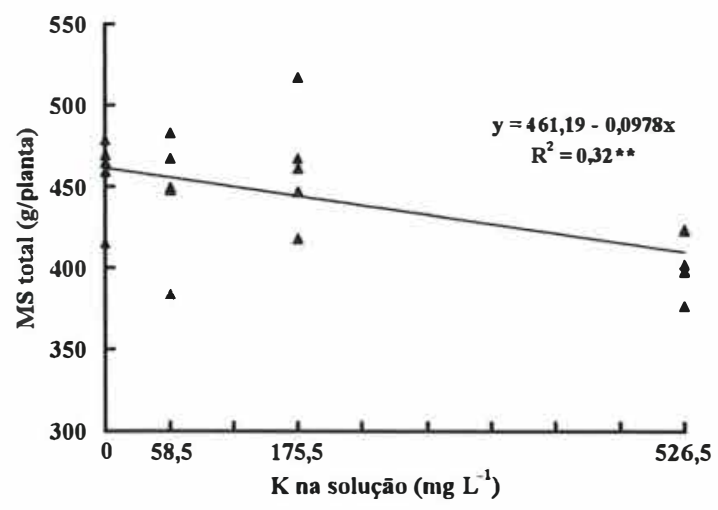

Progênie 3

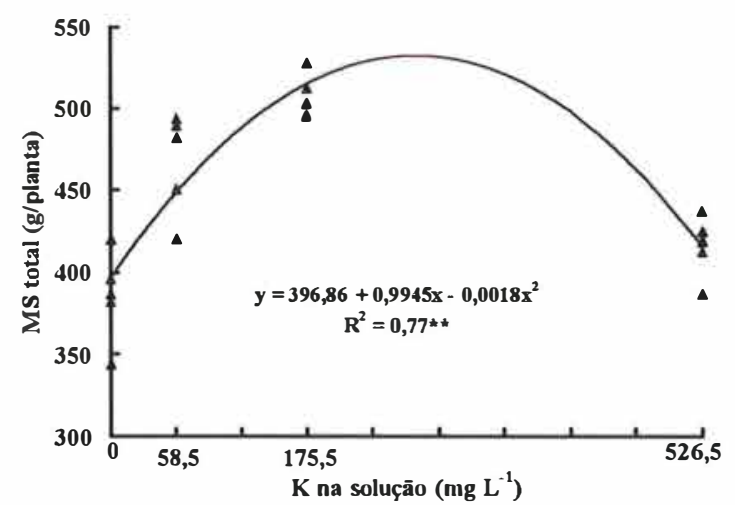

Progênie 2

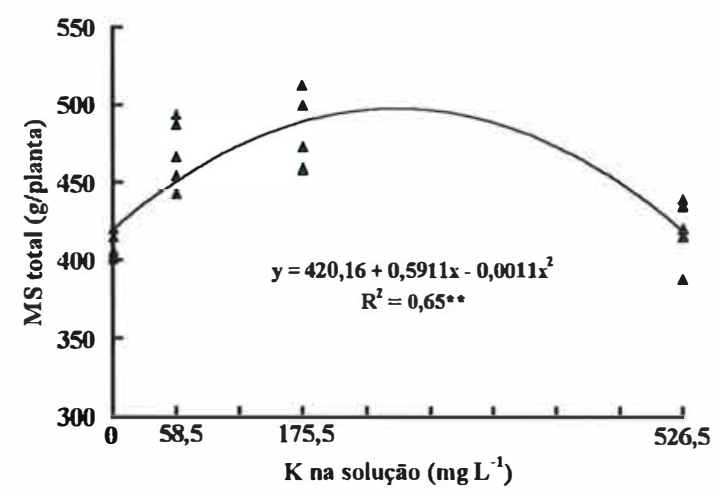

Progênie 4

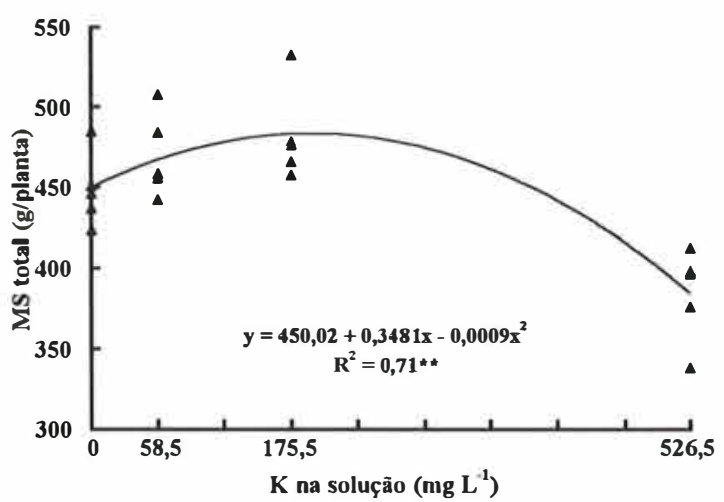

Figura 9. Produção de matéria seca total das progênies de Eucalyptus grandis em função das doses de potássio na solução nutritiva.

MS lenho

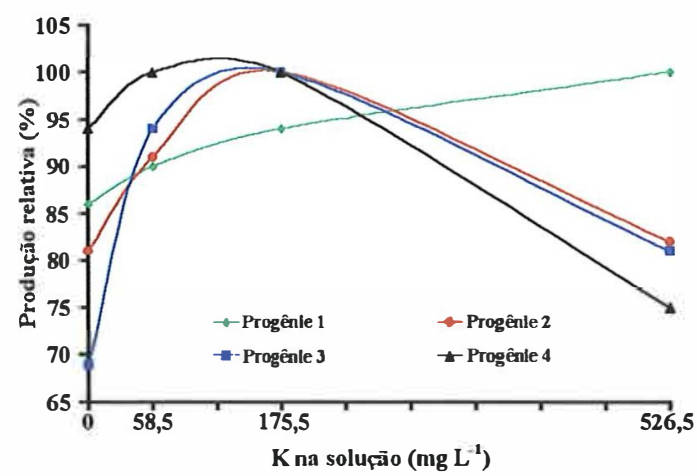

MS total

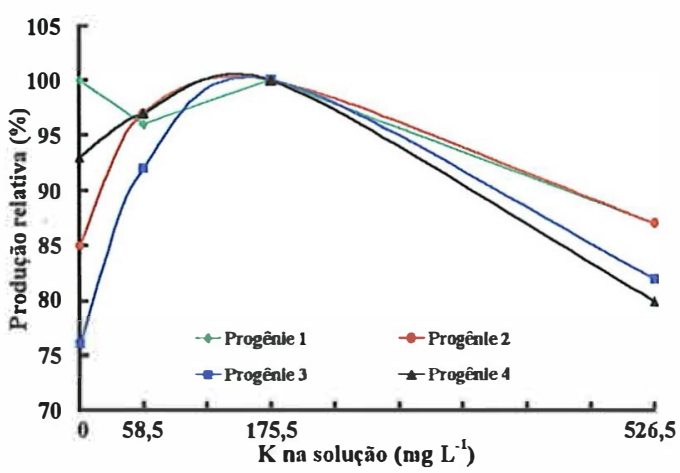

Figura 10. Produção relativa da matéria seca lenhosa e total das progênies de Eucalyptus grandis em função das doses de potássio na solução nutritiva. 


\subsection{Estado nutricional das progênies de Eucalyptus grandis}

\subsubsection{Concentração dos macronutrientes em função das progênies}

A Tabela 20 mostra a concentração dos macronutrientes nos diferentes tipos de folhas dos materiais genéticos de E. grandis. Independente do material genético, as maiores concentrações de $\mathrm{N}, \mathrm{P}$ e $\mathrm{K}$ foram encontradas nas folhas novas seguidas pelas folhas diagnóstico e velhas. Esse gradiente de concentração ocorre em função da mobilidade dos nutrientes na planta, uma vez que estes três macronutrientes apresentam alta translocação dentro da planta (Malavolta et al., 1997). As progênies não diferiram em relação a concentração de cálcio nos três tipos de folhas amostradas (Tabela 20). Em relação ao nitrogênio e magnésio, constatou-se o efeito das progênies nas concentrações foliares. Para a folha nova, verificou-se que as maiores concentrações de $\mathrm{N}$ e $\mathrm{Mg}$ foram encontradas na progênie 3, a mesma tendência foi observada para a concentração de $\mathrm{Mg}$ nas folhas velhas. A concentração de $\mathrm{N}$ nas folhas velhas foi também maior na progênie 3 , porém, não houve diferença entre esta e as progênies 2 e 4 . Na folha diagnóstico, a maior concentração de $\mathrm{Mg}$ foi constatada na progênie 3, havendo diferença desta para as progênies 1 e 4 . A única diferença observada para a concentração de $\mathrm{N}$ nas folhas diagnóstico foi entre as progênies 2 e 3, com maior concentração na última. Em relação ao fósforo, não ocorreu diferença entre as progênies para a concentração nas folhas novas e diagnóstico. O mesmo efeito foi observado para as concentrações de enxofre nas folhas velhas e potássio nas folhas velhas e diagnóstico. A única diferença em termos de concentração de $\mathrm{P}$ ocorreu entre as progênies 2 e 4 quando considerou-se as folhas velhas. Nas folhas novas, constatou-se que a progênie 3 apresentava maior concentração de $\mathrm{K}$ quando comparada com a progênie 1 , bem como, maior concentração de $\mathrm{S}$ em relação as progênies 1 e 2 .

Tais resultados corroboram com os obtidos por Haag et al. (1976) que encontraram diferenças significativas na composição mineral das folhas de cinco espécies de Eucalyptus. Boardman et al. (1997) também verificaram diferenças entre os materiais genéticos de Eucalyptus para a concentração dos nutrientes nas folhas. 
Sem considerar os efeitos das doses de potássio sobre a concentração dos macronutrientes nas folhas diagnóstico, nota-se que todas progênies apresentaram concentrações de N, P e S dentro da faixa considerada adequada para $E$. grandis por Dell et al. (1995) e Boardman et al. (1997). Estas faixas variam de 16 a $29 \mathrm{~g}$ de $\mathrm{N} \mathrm{kg}$ ${ }^{1}, 18$ a $34{\mathrm{~g} \mathrm{de} \mathrm{Ng}^{-1}, 1,0 \text { a 3,0 g de } \mathrm{P} \mathrm{kg}}^{-1}, 1,0$ a 2,2 $\mathrm{g}_{\text {de }} \mathrm{Pg}^{-1}, 1,5$ a 2,0 g de $\mathrm{S} \mathrm{kg}^{-1}$ e 1,5 a 2,3 $\mathrm{g}_{\text {de }} \mathrm{S} \mathrm{kg}^{-1}$, segundo Boardman et al. (1997) e Dell et al. (1995), respectivamente. No entanto, de acordo com Silveira et al. (1999), os valores obtidos para o nitrogênio e o fósforo estavam próximos do limite inferior da faixa adequada, que está compreendida entre 22 a $27 \mathrm{~g}_{\text {de }} \mathrm{N} \mathrm{kg}^{-1}$ e 1,7 a $2,2 \mathrm{~g}_{\text {de }} \mathrm{P} \mathrm{kg}^{-1}$. Em relação ao cálcio, as concentrações obtidas para todos os materiais genéticos foram consideradas adequadas com base em Silveira et al. (1999), porém, bem acima da faixa proposta como adequada por Dell et al. (1995) e Boardman at al. (1997), que varia de 2 a $4 \mathrm{~g}_{\text {de }} \mathrm{Ca} \mathrm{kg}^{-1}$ e 3 a $6 \mathrm{~g} \mathrm{~kg}^{-1}$, respectivamente. A similaridade dos resultados do presente experimento com os obtidos por Silveira et al. (1999), poderia estar no fato de que os plantios de E. grandis amostrados por Silveira et al. (1999), na região de Capão Bonito/SP, estavam deficientes em potássio como no presente estudo, levando, neste caso, a uma maior concentração de Ca nas plantas. As concentrações de $\mathrm{Mg}$ em todas as progênies estavam acima das consideradas adequadas por diversos autores (Dell et al., 1995; Bordman et al, 1997 e Silveira et al., 1999). As razões para as elevadas concentrações de Mg seriam que no presente estudo $25 \%$ das plantas cresceram na carência de $\mathrm{K}$, aumentado a absorção de $\mathrm{Mg}$,

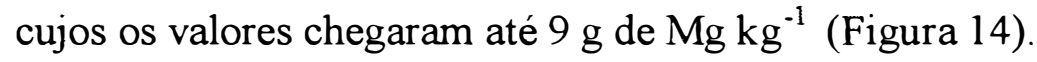


Tabela 20. Concentração de $\mathrm{N}, \mathrm{P}, \mathrm{K}, \mathrm{Ca}, \mathrm{Mg}$ e $\mathrm{S}$ nas folhas novas, velhas e diagnóstico das progênies de Eucalyptus grandis.

\begin{tabular}{|c|c|c|c|c|c|c|}
\hline \multirow[t]{2}{*}{ Material genético } & $\mathrm{N}$ & $P$ & $\mathrm{~K}$ & $\mathrm{Ca}$ & $\mathrm{Mg}$ & $\mathrm{S}$ \\
\hline & \multicolumn{6}{|c|}{$\mathrm{g} \mathrm{kg}^{-1}$} \\
\hline & \multicolumn{6}{|c|}{ Folhas novas } \\
\hline Progênie 1 & $21,8 \mathrm{~b}$ & $1,7 \mathrm{a}$ & $10,5 \mathrm{~b}$ & $10,0 \mathrm{a}$ & $5,2 b$ & $2,2 b c$ \\
\hline Progênie 2 & $23,1 \mathrm{~b}$ & $1,6 \mathrm{a}$ & $11,4 \mathrm{ab}$ & $9,3 \mathrm{a}$ & $5,4 b$ & $2,0 \mathrm{c}$ \\
\hline Progênie 3 & $27,0 \mathrm{a}$ & $1,8 \mathrm{a}$ & $12,5 \mathrm{a}$ & $9,3 \mathrm{a}$ & $6,3 \mathrm{a}$ & $2,7 \mathrm{a}$ \\
\hline Progênie 4 & $24,1 \mathrm{~b}$ & $1,7 \mathrm{a}$ & $11,8 \mathrm{ab}$ & $9,7 \mathrm{a}$ & $5,5 \mathrm{~b}$ & $2,5 \mathrm{ab}$ \\
\hline \multirow[t]{2}{*}{ Média } & 24,0 & 1,7 & 11,5 & 9,6 & 5,6 & 2,3 \\
\hline & \multicolumn{6}{|c|}{ Folhas velhas } \\
\hline Progênie 1 & $15,0 \mathrm{~b}$ & $1,3 \mathrm{ab}$ & $7,0 \mathrm{a}$ & $11,0 \mathrm{a}$ & $5,0 \mathrm{~b}$ & $2,0 \mathrm{a}$ \\
\hline Progênie 2 & $15,4 \mathrm{ab}$ & $1,2 \mathrm{~b}$ & $6,9 \mathrm{a}$ & $10,8 \mathrm{a}$ & $5,1 \mathrm{~b}$ & $1,8 \mathrm{a}$ \\
\hline Progênie 3 & $16,7 \mathrm{a}$ & $1,3 \mathrm{ab}$ & $7,0 \mathrm{a}$ & $10,5 \mathrm{a}$ & $5,9 \mathrm{a}$ & $2,1 \mathrm{a}$ \\
\hline Progênie 4 & $15,9 a b$ & $1,4 \mathrm{a}$ & $6,9 a$ & $10,3 \mathrm{a}$ & $5,2 b$ & $2,1 \mathrm{a}$ \\
\hline \multirow[t]{2}{*}{ Média } & 15,75 & 1,3 & 6,95 & 10,6 & 5,3 & 2,0 \\
\hline & \multicolumn{6}{|c|}{ Folhas diagnóstico } \\
\hline Progênie 1 & $19,0 \mathrm{ab}$ & $1,6 \mathrm{a}$ & $8,5 \mathrm{a}$ & $8,4 \mathrm{a}$ & $4,8 \mathrm{~b}$ & $2,1 \mathrm{ab}$ \\
\hline Progênie 2 & $18,0 \mathrm{~b}$ & $1,4 \mathrm{a}$ & $8,3 \mathrm{a}$ & $8,7 \mathrm{a}$ & $5,1 \mathrm{ab}$ & $2,0 \mathrm{~b}$ \\
\hline Progênie 3 & $21,2 \mathrm{a}$ & $1,5 \mathrm{a}$ & $8,3 \mathrm{a}$ & $8,1 \mathrm{a}$ & $5,6 \mathrm{a}$ & $2,3 \mathrm{ab}$ \\
\hline Progênie 4 & $20,0 \mathrm{ab}$ & $1,5 \mathrm{a}$ & $9,0 \mathrm{a}$ & $8,2 \mathrm{a}$ & $5,0 \mathrm{~b}$ & $2,4 \mathrm{a}$ \\
\hline Média & 19,5 & 1,5 & 8,5 & 8,3 & 5,1 & 2,2 \\
\hline
\end{tabular}

Médias seguidas de mesma letra nào diferem entre si pelo teste de Tukey ao nivel de $5 \%$ de probabilidade.

As concentrações dos macronutrientes nos ramos, casca e lenho das progênies, independente das doses de potássio, são apresentadas na Tabela 21. Para os ramos, não constatou-se diferença entre os materiais genéticos para as concentrações de $\mathrm{N}, \mathrm{K}$ e Ca. Para o fósforo, foram encontradas diferenças entre os materiais genéticos, sendo que a concentração de $\mathrm{P}$ nos ramos obedeceu a seguinte ordem: progênie $2>$ progênie $>1$ progênie $3=$ progênie 4 . Em relação ao magnésio, as maiores concentrações foram encontradas na progênie 4, a qual diferiu das demais. As progênies 3 e 4 apresentaram maiores concentrações de enxofre nos ramos em relação as outras duas. De maneira geral, as concentrações de $\mathrm{N}$ nos ramos estavam próximas da encontrada em $E$. grandis $\left(3,4 \mathrm{~g} \mathrm{~kg}^{-1}\right)$ por Leite et al. (1998) e em várias espécies de Eucalyptus $\left(4 \mathrm{~g} \mathrm{~kg}^{-1}\right)$ por Judd (1996). As concentrações de $\mathrm{P}$ estavam cerca de 2,5 vezes 
maiores que a obtida por Leite et al. (1998) e Judd (1996). As maiores concentrações de $\mathrm{P}$ nos ramos poderiam ser explicadas pela idade das plantas, uma vez que Barros \& Novais (1990) relatam que a exigência de fósforo pelo eucalipto diminui com o aumento da idade das plantas. As concentrações de $\mathrm{Ca}$ e $\mathrm{Mg}$ foram bem superiores as observadas por Judd (1996) e Leite at al. (1998), porém, esses autores não trabalharam com árvores submetidas a carência de potássio, que por sua vez favorece uma maior absorção desses macronutrientes.

Houve diferença entre as progênies para a concentração dos macronutrientes na casca, com exceção do $\mathrm{N}$ e $\mathrm{Ca}$ (Tabela 21). As maiores concentrações de $\mathrm{P}, \mathrm{S}$ e $\mathrm{Mg}$ foram encontradas na progênie 4. Para o potássio, verificou-se que a progênie 1 apresentava menor concentração em comparação com as progênies 3 e 4 . As concentrações de $\mathrm{N}$ na casca estavam próximas da obtida para $E$. grandis $\left(2,4 \mathrm{~g} \mathrm{~kg}^{-1}\right)$ por Leite et al. (1998) e para várias espécies de Eucalyptus (3,5 $\left.\mathrm{g} \mathrm{kg}^{-1}\right)$ por Judd (1996). Conforme já observado para os ramos, a concentração de fósforo na casca foi cerca de 5 vezes maior que as relatadas por Judd (1996) e Leite et al. (1998). As concentrações de Ca na casca estavam acima da encontrada em E. grandis $\left(8,6 \mathrm{~g} \mathrm{~kg}^{-1}\right)$ por Leite et al. (1998) e próxima da observada em espécies de Eucalyptus (24 $\left.\mathrm{g} \mathrm{kg}^{-1}\right)$ por Judd (1996). Em condições de campo, a concentração de Ca na casca do Eucalyptus também é alta (Bellote, 1979; Reis et al., 1987; Morais; 1990). Desta forma, torna-se necessário fazer o descascamento no campo, para diminuir a exportação do $\mathrm{Ca}$ pela madeira. As concentrações obtidas de Mg na casca estavam acima das encontradas por Judd (1996) e

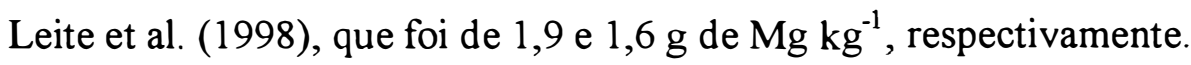

Em relação as concentrações dos macronutrientes no lenho, verificou-se que para o fósforo e enxofre não ocorreu diferença entre os materiais genéticos, contrário ao constatado para a casca e os ramos (Tabela 21). As progênies diferiram em relação a concentração de $\mathrm{N}$ no lenho, sendo que o mesmo não foi observado quando analisou-se as concentrações de $\mathrm{N}$ na casca e nos ramos. A única diferença foi que a progênie 3 apresentou maior concentração de $\mathrm{N}$ na madeira em relação a progênie 4. Para o potássio, a diferença ocorreu entre as progênies 1 e 4 , sendo que a progênie 1 apresentou maior concentração. Os resultados da concentração de $\mathrm{Ca}$ no lenho dos materiais 
genéticos foram opostos aos encontrados para os ramos e casca, ou seja, houve diferença entre as progênies. A progênie 1 apresentou maior concentração de $\mathrm{Ca}$ em relação as progênies 3 e 4 . A mesma tendência foi observada em relação ao magnésio, uma vez que a progênie 1 foi a que teve maior concentração. As concentrações dos macronutrientes no lenho foram superiores as observadas por Judd (1996) e Leite et al. (1998), exceto o nitrogênio, cujos os valores foram muito próximo do encontrado por Judd (1996) em várias espécies de Eucalyptus. As concentrações de $\mathrm{P}, \mathrm{K}, \mathrm{Ca}$ e $\mathrm{Mg}$ foram maiores que as encontradas por Judd (1996) e Leite et al. (1998) cerca de: 6 a 12 vezes para P; 1,8 a 2,2 vezes para $\mathrm{K} ; 1,8$ a 2,6 vezes para $\mathrm{Ca}$ e 2,3 a 5,0 vezes para $\mathrm{Mg}$. As razões para a alta concentração dos macronutrientes no lenho poderiam ser devido a idade da planta, uma vez que plantas jovens apresentam maior atividade fisiológica, necessitando de maior quantidade de nutrientes.

Tabela 21. Concentração de N, P, K, Ca, Mg e S nos ramos, lenho e casca das progênies de Eucalyptus grandis.

\begin{tabular}{|c|c|c|c|c|c|c|}
\hline \multirow[t]{2}{*}{ Material genético } & $\mathrm{N}$ & $\mathrm{P}$ & $\mathrm{K}$ & $\mathrm{Ca}$ & $\mathrm{Mg}$ & $S$ \\
\hline & \multicolumn{6}{|c|}{$\mathrm{g} \mathrm{kg}^{-1}$} \\
\hline & \multicolumn{6}{|c|}{ Ramos } \\
\hline Progênie 1 & $3,0 \mathrm{a}$ & $1,2 \mathrm{~b}$ & $2,3 \mathrm{a}$ & $11,6 a$ & $3,5 \mathrm{~b}$ & $0,5 \mathrm{~b}$ \\
\hline Progênie 2 & $2,8 \mathrm{a}$ & $1,3 \mathrm{a}$ & $2,3 \mathrm{a}$ & $10,9 \mathrm{a}$ & $4,5 \mathrm{~b}$ & $0,5 \mathrm{~b}$ \\
\hline Progênie 3 & 3,1 a & $1,0 \mathrm{c}$ & $2,4 \mathrm{a}$ & $11,1 \mathrm{a}$ & $4,3 \mathrm{~b}$ & $0,7 \mathrm{a}$ \\
\hline Progênie 4 & 3,1 a & $1,0 \mathrm{c}$ & $2,2 \mathrm{a}$ & $11,6 \mathrm{a}$ & $5,8 \mathrm{a}$ & $0,7 \mathrm{a}$ \\
\hline \multirow[t]{2}{*}{ Média } & 3,0 & 1,1 & 2,3 & 11,3 & 4,5 & 0,6 \\
\hline & \multicolumn{6}{|c|}{ Casca } \\
\hline Progênie 1 & $2,8 \mathrm{a}$ & $2,2 a b$ & $2,2 b$ & $22,7 \mathrm{a}$ & $2,4 \mathrm{c}$ & $0,8 \mathrm{ab}$ \\
\hline Progênie 2 & $2,8 \mathrm{a}$ & $2,0 \mathrm{bc}$ & $2,3 \mathrm{ab}$ & $21,0 \mathrm{a}$ & $2,6 \mathrm{c}$ & $0,7 \mathrm{~b}$ \\
\hline Progênie 3 & $2,7 \mathrm{a}$ & $2,0 \mathrm{c}$ & $2,4 \mathrm{a}$ & 21,1 a & $3,0 \mathrm{~b}$ & $0,8 a b$ \\
\hline Progênie 4 & $2,6 \mathrm{a}$ & $2,3 \mathrm{a}$ & $2,4 \mathrm{a}$ & 20,6 a & $3,4 \mathrm{a}$ & $0,9 \mathrm{a}$ \\
\hline \multirow[t]{2}{*}{ Média } & 2,6 & 2,1 & 2,3 & 21,3 & 2,8 & 0,8 \\
\hline & \multicolumn{6}{|c|}{ Lenho } \\
\hline Progênie 1 & $1,2 \mathrm{ab}$ & $0,6 \mathrm{a}$ & $2,9 a$ & $2,1 \mathrm{a}$ & $0,8 \mathrm{a}$ & $0,3 \mathrm{a}$ \\
\hline Progênie 2 & $1,2 \mathrm{ab}$ & $0,6 a$ & $2,6 \mathrm{ab}$ & $1,8 \mathrm{ab}$ & $0,7 \mathrm{ab}$ & $0,3 \mathrm{a}$ \\
\hline Progênie 3 & $1,3 \mathrm{a}$ & $0,6 a$ & $2,5 \mathrm{ab}$ & $1,7 \mathrm{~b}$ & $0,7 \mathrm{ab}$ & $0,3 \mathrm{a}$ \\
\hline Progênie 4 & $1,1 \mathrm{~b}$ & $0,5 \mathrm{a}$ & $2,4 \mathrm{~b}$ & $1,6 \mathrm{~b}$ & $0,6 \mathrm{~b}$ & $0,3 \mathrm{a}$ \\
\hline Média & 1,2 & 0,6 & 2,6 & 1,8 & 0,7 & 0,3 \\
\hline
\end{tabular}

Médias seguidas de mesma latra não diferem entre si pelo teste de Tukey ao nivel de $5 \%$ de probabilidade. 


\subsubsection{Efeito das doses de potássio sobre a concentração dos macronutrientes}

$\mathrm{Na}$ Tabela 22 são apresentados os coeficientes de correlações de Pearson entre as doses de potássio na solução e a concentração dos macronutrientes nas diferentes partes das progênies. Como era de se esperar, o aumento das doses de potássio na solução nutritiva proporcionou aumentos nas concentrações de $\mathrm{K}$ nos tecidos vegetais de todas as progênies. No entanto, as folhas apresentaram comportamentos diferenciados em relação as demais partes da planta, uma vez que os efeitos das doses sobre a concentração de K se manifestaram de forma linear (Figuras 11), enquanto que para os ramos, casca e lenho, quadrática (Figura 12). Segundo Malavolta et al. (1997), o potássio é um elemento de alta redistribuição dentro da planta. Esta afirmação pode ser constatada ao comparar a concentração de $\mathrm{K}$ nos diferentes tipos de folhas das progênies, principalmente nas doses mais elevadas de $\mathrm{K}$, onde ocorreu um gradiente de concentração na seguinte ordem: folhas novas $>$ folhas diagnóstico $>$ folhas velhas (Figura 11). Para as demais partes da planta, nota-se que a partir da dose de $175,5 \mathrm{mg}$ de $\mathrm{K} \mathrm{L}^{-1}$, os aumentos de concentração de $\mathrm{K}$ nos tecidos foram decrescente, tendendo a uma estabilização (Figura 12).

As correlações mostraram que o aumento das doses de potássio proporcionou menor concentração de $\mathrm{Ca}$ e $\mathrm{Mg}$ nos três tipos de folhas dos materiais genéticos, sendo o efeito mais pronunciado no caso do cálcio, para as progênies 3 e 4 (Tabela 22). Para as outras partes da planta, as respostas na concentração de $\mathrm{Ca}$ e $\mathrm{Mg}$ ocorreram de forma diferenciada entre as progênies. Nos ramos, houve decréscimo na concentração de $\mathrm{Ca}$ e $\mathrm{Mg}$ com os aumentos da dose de $\mathrm{K}$, apenas para a progênie 2. Em relação a casca, foram encontradas correlações negativas para todos os materiais, com exceção do Ca para a progênie 4 e $\mathrm{Mg}$ para a progênie 3. No lenho, correlação negativa entre as doses de $\mathrm{K}$ e a concentração de $\mathrm{Ca}$ foi observada apenas na progênie 3 . Decréscimos na concentração de $\mathrm{Mg}$ no lenho com o maior fornecimento de potássio ocorreram para todos os genótipos, exceto para a progênie 4. Tais resultados mostram que o efeito do íon $\mathrm{K}$ sobre a absorção do $\mathrm{Ca}$ e $\mathrm{Mg}$ ocorrem na forma de inibição competitiva, uma vez que esses cátions se combinam pelo mesmo sítio ativo do carregador (Malavolta et al., 1997). Resultados semelhantes foram encontrados por 
Knight (1988), que encontrou correlações negativas entre a concentração de potássio nas folhas e a de cálcio $(r=-0,70)$ e a de magnésio $(r=-0,84)$ para $E$. fastigata com 3 anos de idade. Schonau (1981) também verificou que a aplicação de $\mathrm{K}$ reduzia o teor de $\mathrm{Ca}$, enquanto que a aplicação de calcário deprimia o teor de $\mathrm{K}$ em E. grandis.

Tabela 22. Coeficientes de correlações de Pearson entre as doses de potássio na solução nutritiva e a concentração dos macronutrientes nas diferentes partes das plantas das progènies de Eucalyptus grandis.

\begin{tabular}{|c|c|c|c|c|c|c|}
\hline $\begin{array}{l}\text { Material } \\
\text { Genético }\end{array}$ & $\overline{\mathrm{N}}$ & $\bar{P}$ & $\overline{\mathrm{K}}$ & $\overline{\mathrm{Ca}}$ & $\mathrm{Mg}$ & $\overline{\mathrm{S}}$ \\
\hline & \multicolumn{6}{|c|}{ Folhas novas } \\
\hline Progênie 1 & ns & $0,78^{* *}$ & $0,95 * *$ & $-0,47^{*}$ & $-0,74^{* *}$ & $-0,72 * *$ \\
\hline Progênie 2 & ns & ns & $0,94 * *$ & $-0,72^{* *}$ & $-0,63 * *$ & $-0,66^{* *}$ \\
\hline Progênie 3 & $-0,67 * *$ & ns & $0,99 * *$ & $-0,89 * *$ & $-0,62 * *$ & $-0,67 * *$ \\
\hline Progênie 4 & $-0,56 * *$ & ns & $0,92 * *$ & $-0,83 * *$ & $-0,79 * *$ & $-0,51^{*}$ \\
\hline \multirow[t]{2}{*}{ Todos } & $-0,41^{*}$ & ns & $0,94 * *$ & $-0,71^{* *}$ & $-0,65 * *$ & $-0,60^{* *}$ \\
\hline & \multicolumn{6}{|c|}{$\begin{array}{c}\text { Folhas velhas } \\
\end{array}$} \\
\hline Progênie 1 & $-0,60^{* *}$ & $\mathrm{~ns}$ & $0,93^{* *}$ & $-0,65 * *$ & $-0,64^{* *}$ & ns \\
\hline Progênie 2 & ns & ns & $0,91 * *$ & $-0,65 * *$ & $-0,67 * *$ & $-0,56^{* *}$ \\
\hline Progênie 3 & ns & ns & $0,98 * *$ & $-0,85^{* *}$ & $-0,76^{* *}$ & $-0,63^{* *}$ \\
\hline Progênie 4 & ns & $0,53^{*}$ & $0,96 * *$ & $-0,86^{* *}$ & $-0,84^{* *}$ & $-0,61 * *$ \\
\hline \multirow[t]{2}{*}{ Todos } & ns & ns & $0.94^{* *}$ & $-0,75^{* *}$ & $-0,71^{* *}$ & $-0,55^{* *}$ \\
\hline & \multicolumn{6}{|c|}{ Folhas diagnóstico } \\
\hline Progênie 1 & ns & $0,56^{* *}$ & $0,99 * *$ & $-0,60^{* *}$ & $-0,66^{* *}$ & $-0,74^{* *}$ \\
\hline Progênie 2 & $-0,58^{* *}$ & ns & $0,90 * *$ & $-0,60 * *$ & $-0,74^{* *}$ & $-0,70 * *$ \\
\hline Progênie 3 & $-0,61 * *$ & ns & $0,97 * *$ & $-0,78^{* *}$ & $-0,76^{* *}$ & $-0,72^{* *}$ \\
\hline Progênie 4 & $-0,53^{*}$ & ns & $0,95 * *$ & $-0,72^{* *}$ & $-0,77^{* *}$ & $-0,69 * *$ \\
\hline \multirow[t]{2}{*}{ Todos } & $-0,40^{* *}$ & ns & $0.95^{* *}$ & $-0,65^{* *}$ & $-0,71^{* *}$ & $-0,68^{* *}$ \\
\hline & \multicolumn{6}{|c|}{ Ramos } \\
\hline Progênie 1 & ns & $0,87^{* *}$ & $0,89^{* *}$ & ns & ns & ns \\
\hline Progênie 2 & $-0,45^{*}$ & $0.78^{* *}$ & $0,87 * *$ & $-0,59 * *$ & $-0,77^{* *}$ & $-0.53^{* *}$ \\
\hline Progênie 3 & ns & $0,54 * *$ & $0,84^{* *}$ & ns & ns & ns \\
\hline Progênie 4 & $-0,61 * *$ & $0,40^{*}$ & $0,95^{* *}$ & $-0,80^{* *}$ & ns & ns \\
\hline \multirow[t]{2}{*}{ Todos } & ns & $0,45^{* *}$ & $0.89 * *$ & $-0,44^{* *}$ & $-0,40^{* *}$ & ns \\
\hline & \multicolumn{6}{|c|}{ Casca } \\
\hline Progênie 1 & ns & ns & $0,85^{* *}$ & $-0,51^{*}$ & $-0,72^{* *}$ & ns \\
\hline Progênie 2 & ns & ns & $0,93^{* *}$ & $-0,61 * *$ & $-0,64^{* *}$ & $-0,42^{*}$ \\
\hline Progênie 3 & ns & ns & $0,91^{* *}$ & $-0,46^{*}$ & ns & ns \\
\hline Progênie 4 & ns & ns & $0,86^{* *}$ & ns & $-0,48^{*}$ & ns \\
\hline \multirow[t]{2}{*}{ Todos } & ns & $\mathrm{ns}$ & $0.88^{* *}$ & $-0,30^{* *}$ & $-0,46^{* *}$ & ns \\
\hline & \multicolumn{6}{|c|}{ Lenho } \\
\hline Progênie 1 & ns & ns & $0,83^{* *}$ & ns & $-0,65^{* *}$ & $-0,97 * *$ \\
\hline Progênie 2 & ns & $0,57^{* *}$ & $0,83^{* *}$ & ns & $-0,60^{* *}$ & $-0,81^{* *}$ \\
\hline Progênie 3 & $-0,83^{* *}$ & ns & $0,90 * *$ & $-0,65^{* *}$ & $-0,54^{* *}$ & $-0,86^{* *}$ \\
\hline Progênie 4 & $-0,73^{* *}$ & ns & $0,91 * *$ & ns & ns & ns \\
\hline Todos & $-0.48^{* *}$ & ns & $0.84^{* *}$ & $-0.34^{*}$ & $-0,50^{* *}$ & $-0.84^{* *}$ \\
\hline
\end{tabular}



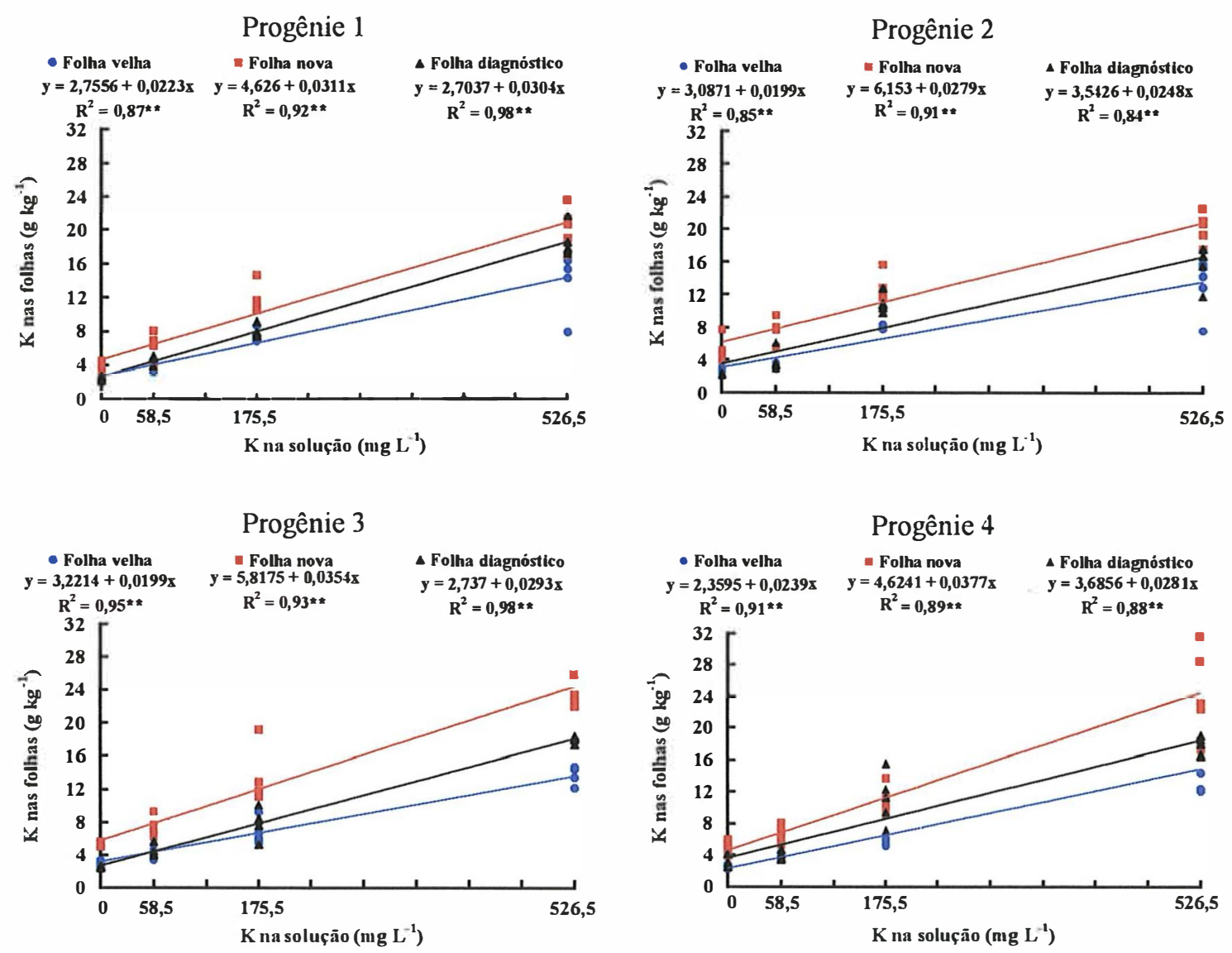

Figura 11. Concentração de potássio nas folhas novas, velhas e diagnóstico das progênies de Eucalyptus grandis em função das doses de potássio na solução nutritiva. 

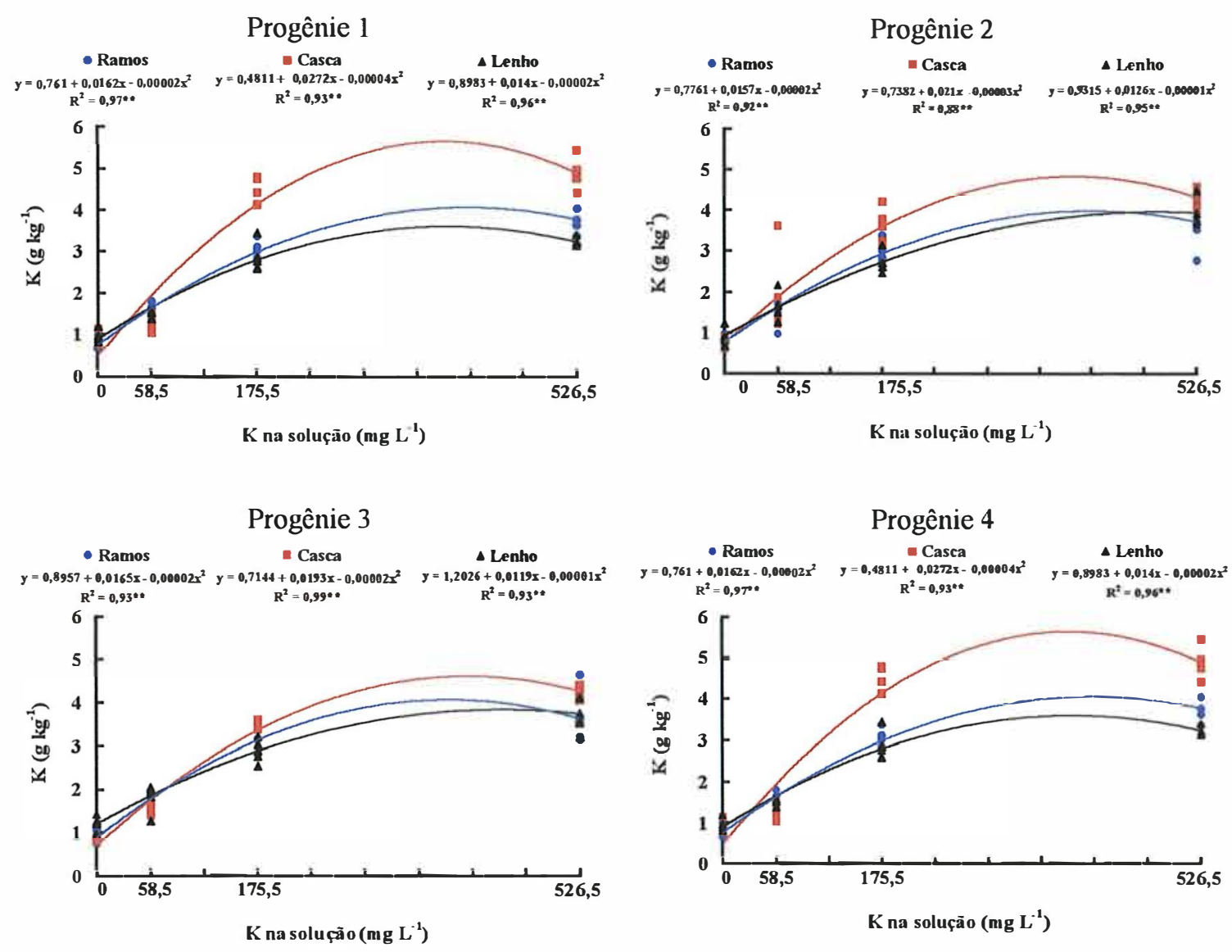

Figura 12. Concentração de potássio nos ramos, casca e lenho das progênies de Eucalyptus grandis em função das doses de potássio na solução nutritiva.

As Figuras 13 e 14 mostram o efeito das doses de K sobre a concentração de $\mathrm{Ca}$ e $\mathrm{Mg}$ nas folhas novas, velhas e diagnóstico das progênies, respectivamente. As progênies 3 e 4 apresentaram comportamentos semelhantes, sendo que a concentração de $\mathrm{Ca}$ nos diferentes tipos de folhas diminuiu linearmente com o aumento do fornecimento de potássio. Para as progênies 1 e 2 , diminuiu linearmente até a dose de $175,5 \mathrm{mg} \mathrm{L}^{-1}$, a partir da qual verificou-se uma tendência de estabilização da concentração desse macronutriente (Figura 13). Em relação as concentrações de Mg nas folhas, os dados revelam similaridade entre os materiais genéticos (Figura 14), com quedas acentuadas na concentração de $\mathrm{Mg}$ na medida em que se aumentou a dose de $\mathrm{K}$ 
na solução até $175,5 \mathrm{mg} \mathrm{L}^{-1}$, não havendo redução de $\mathrm{Mg}$ nas folhas entre esta dose e a de $526,5 \mathrm{mg} \mathrm{L}^{-1}$.
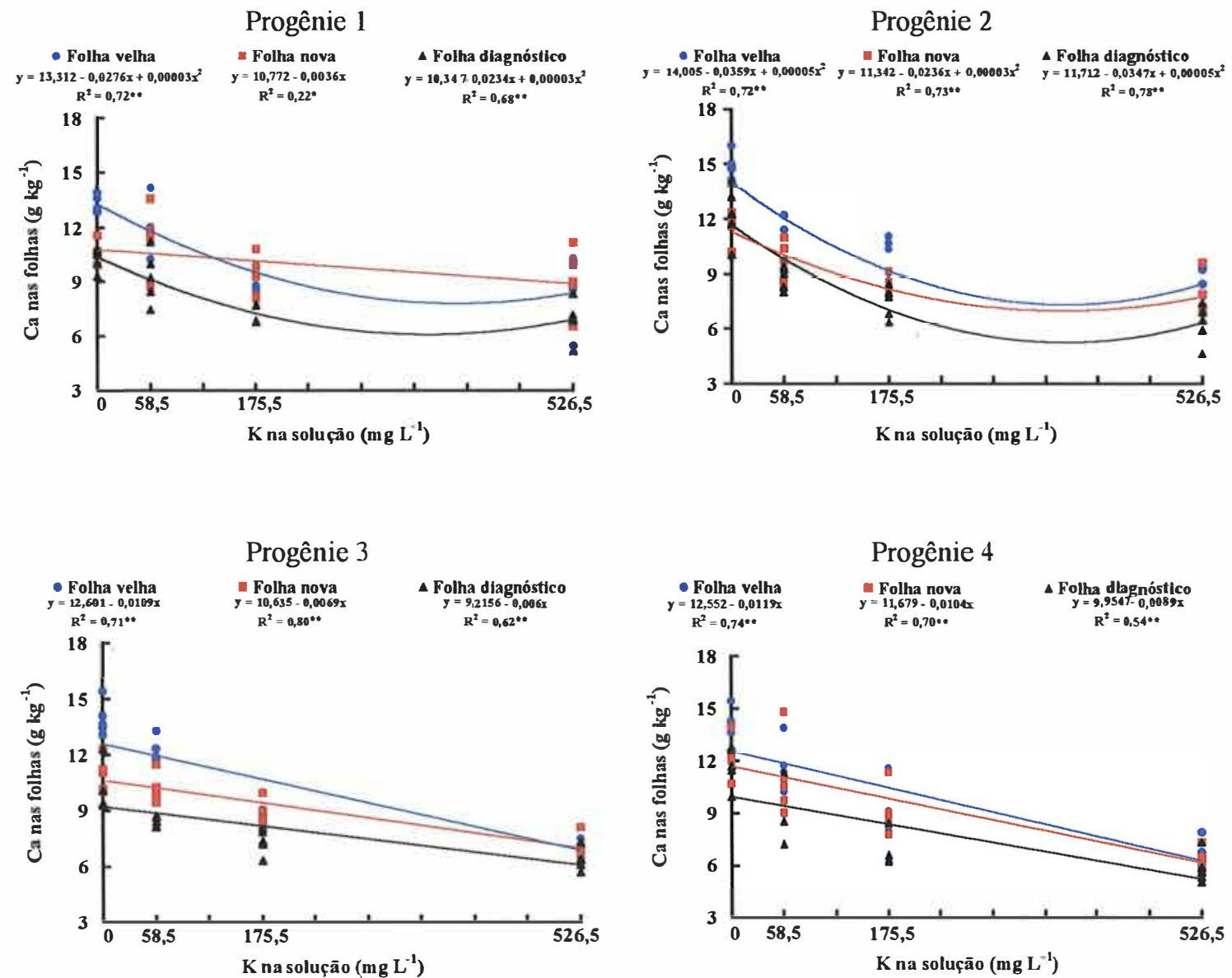

Figura 13. Concentração de cálcio nas folhas novas, velhas e diagnóstico das progênies de Eucalyptus grandis em função das doses de potássio na solução nutritiva. 

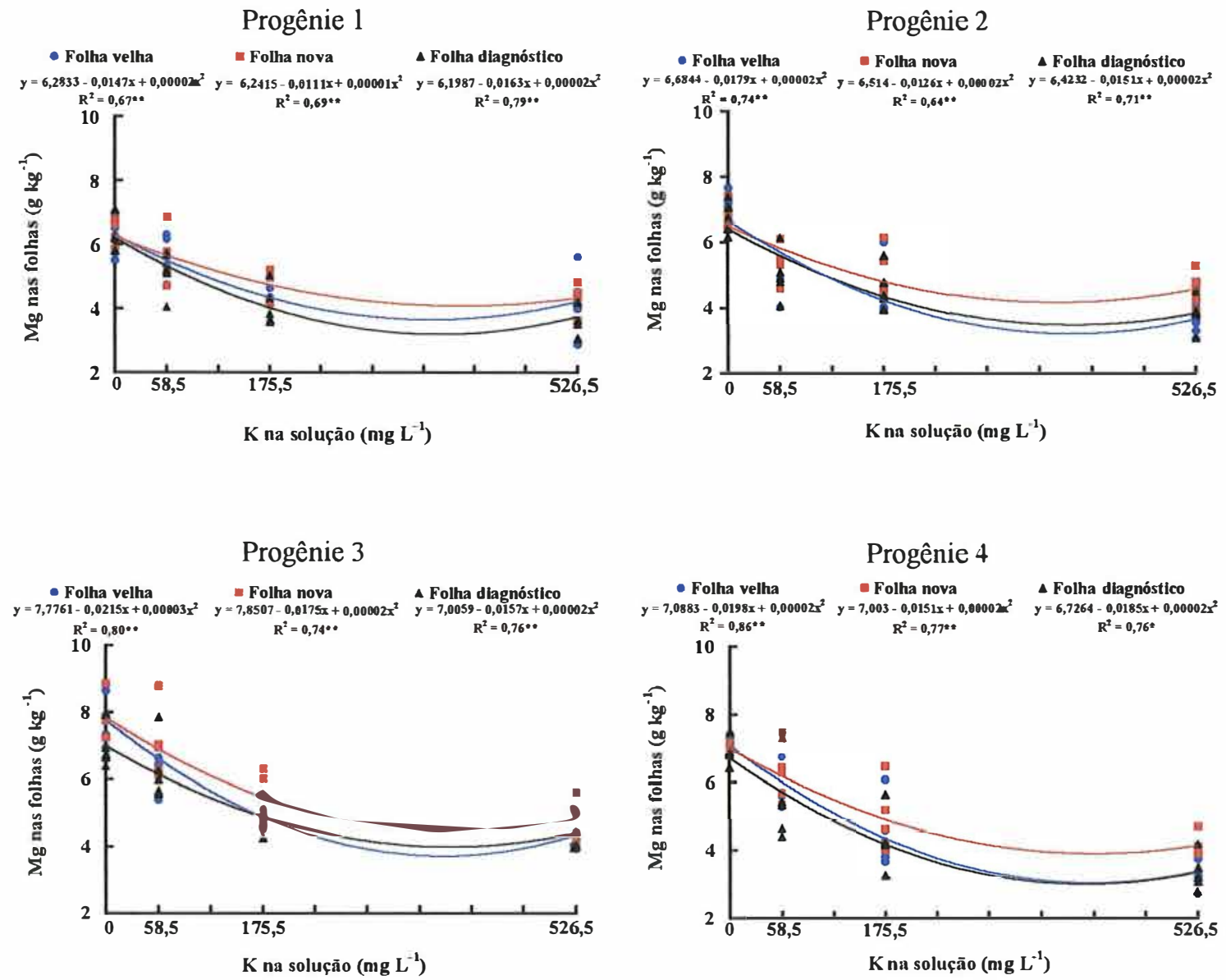

Figura 14. Concentração de magnésio nas folhas novas, velhas e diagnóstico das progênies de Eucalyptus grandis em função das doses de potássio na solução nutritiva.

Os dados de concentração dos macronutrientes nas várias partes da planta revelaram que a concentração de $\mathrm{P}$ nos ramos aumentou com o fornecimento de $\mathrm{K}$ na solução para todas as progênies, sendo os efeitos mais acentuados nas progênies 1 e 2 (Tabela 22). Constatou-se ainda, que as concentrações de $\mathrm{N}$ nas folhas diagnóstico diminuía com o aumento do $\mathrm{K}$ na solução, com exceção da progênie 1. Em relação ao enxofre, as concentrações nas folhas e no lenho decresciam com o maior suprimento de $\mathrm{K}$. Tal fato é um efeito indireto do potássio, uma vez que com o aumento da dose de $\mathrm{K}$ na solução, uma maior quantidade de cloreto de potássio entrou na sua composição (Tabela 8). Portanto, os efeitos na inibição da absorção de sulfato ocorreram devido aos aumentos de cloreto na solução (Figura 15). 
Efeito menos pronunciados ocorreram entre a concentração de cloro na solução e a de nitrogênio nas folhas diagnóstico, exceto para a progênie 1 (progênie $2-r$ $=-0,53$; progênie $3-r=-0,63$ e progênie $4-r=-0,59$ ). Esses resultados são explicados pela inibição competitiva que ocorre entre o íon $\mathrm{Cl}^{-}$e os íons $\mathrm{SO}_{4}{ }^{-2}$ e $\mathrm{NO}_{3}^{-}$(Malavolta et al., 1997). No presente estudo, as concentrações de cloro obtidas nas folhas diagnóstico nas doses mais elevadas foram consideradas altas com base em Boardman et al. (1997), que cita que valores acima de $4 \mathrm{~g} \mathrm{de} \mathrm{Cl} \mathrm{kg}^{-1}$ são elevados para $E$. grandis na fase juvenil.

Progênie 1

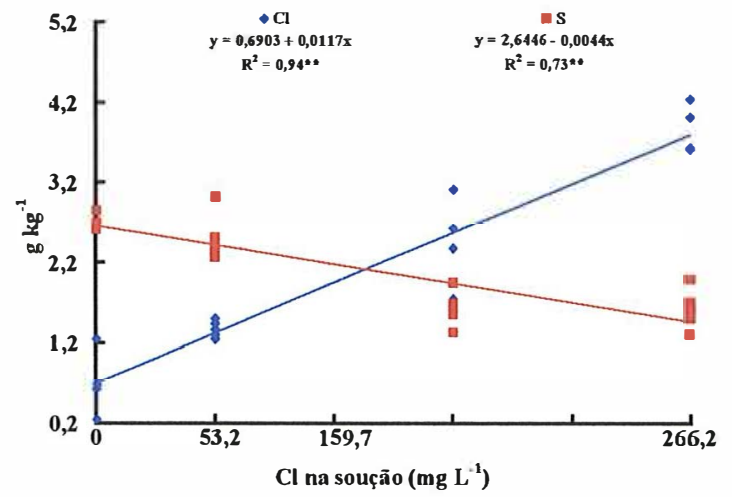

Progênie 3

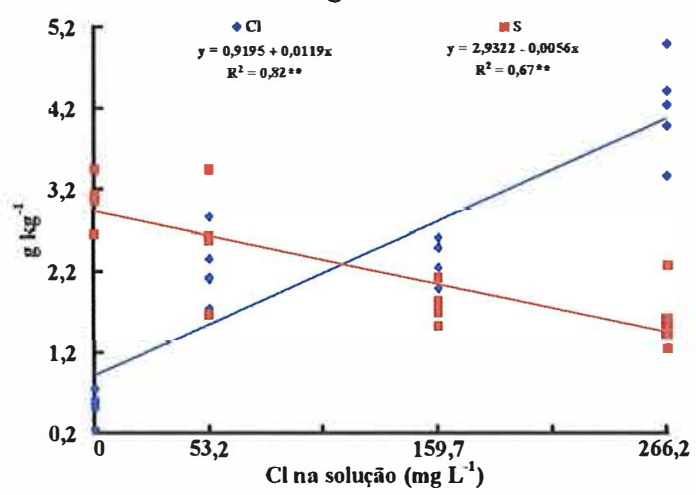

Progênie 2

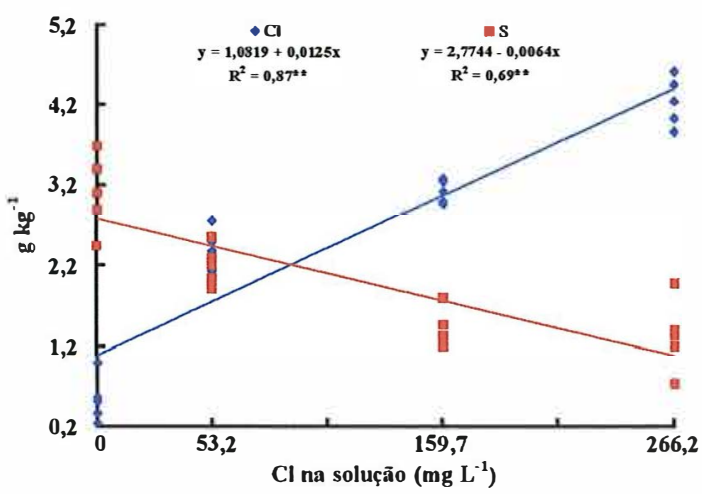

Progênie 4

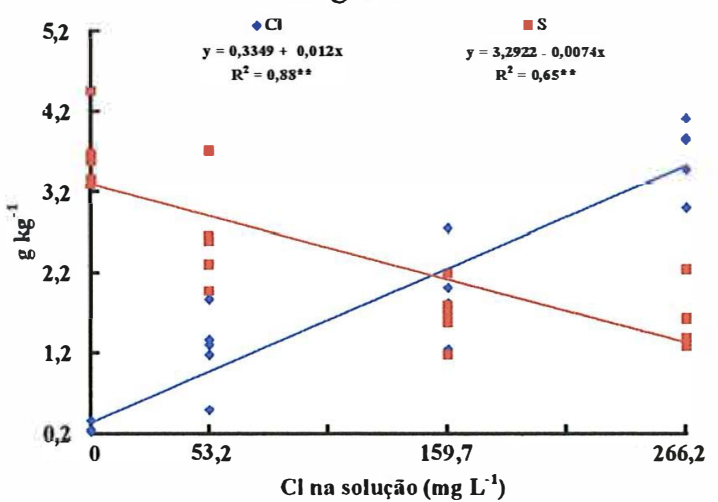

Figura 15. Concentração de cloro e enxofre nas folhas diagnóstico das progênies de Eucalyptus grandis em função das doses de cloro na solução nutritiva.

As concentrações de enxofre nas folhas diagnóstico encontradas na maior dose de $\mathrm{Cl}$ foram de $1,5,1,1,1,4$ e $1,3 \mathrm{~g} \mathrm{~kg}^{-1}$, respectivamente nas progênies $1,2,3$ e 4 (Figura 15). Os valores obtidos para a progênie 2 foram considerados deficientes com 
base em Malavolta (1987) e Silveira et al. (1999), os quais citam que a deficiência de S está associada a valores de 0,8 a 1,2 $\mathrm{g} \mathrm{kg}^{-1} \mathrm{e}<1,3 \mathrm{~g} \mathrm{~kg}^{-1}$ nas folhas de eucalipto, respectivamente. Nas demais progênies, as concentrações de enxofre também não foram

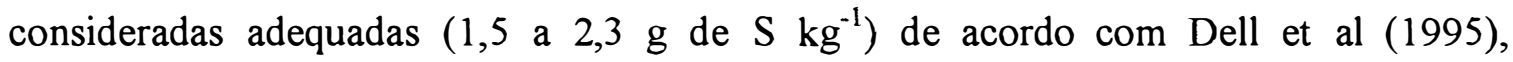
Gonçalves (1995), Boardman et al. (1997) e Silveira et al. (1999), com exceção da progênie 4 , cujo os valores estavam no limite inferior da faixa adequada. As concentrações de enxofre nas folhas diagnóstico explicariam a clorose generalizada das folhas novas descritas no item 4.2.2.

\subsubsection{Concentração dos micronutrientes em função das progênies}

A Tabela 23 mostra a concentração dos micronutrientes nos diferentes tipos de folhas em função do material genético. Em relação a concentração de boro, não houve diferença significativa entre as progênies tanto para as folhas novas como velhas. A única diferença foi encontrada na folha diagnóstico, quando comparou-se a progênie 1 com a progênie 4 . Nos três tipos de folhas ocorreram diferenças significativas entre as progênies para a concentração de cobre, principalmente nas folhas novas. Neste caso, a progênie 1 apresentou maior concentração quando comparada com as demais, sendo que a mesma tendência foi constatada para as folhas velhas e diagnóstico.

Os materiais genéticos também diferiram em relação a concentração de ferro nas folhas. Nas folhas novas, a maior concentração foi obtida na progênie 1, diferindo estatisticamente da progênie 3. Nas folhas velhas, verificou-se que a progênie 1 apresentou maior concentração de Fe quando comparada com as progênies 3 e 4 . Para a folha diagnóstico, as diferenças ocorreram entre a progênie 4 e as progênies 2 e 3 , sendo a maior concentração encontrada na primeira. Não houve diferença entre os genótipos para a concentração de Mn nas folhas diagnóstico. No entanto, observou-se maior concentração nas progênies 2 e 3 em relação as progênies 1 e 4, para as folhas novas, enquanto que nas folhas velhas a menor concentração foi encontrada na progênie 4.

Em relação ao zinco, as maiores concentrações nas folhas novas e velhas foram verificadas na progênie 1 . Resultados diferentes foram verificados para as folhas 
diagnóstico, uma vez que as maiores concentrações foram encontradas nas progênies 3 e 4.

De maneira geral, as concentrações de $\mathrm{B}, \mathrm{Cu}, \mathrm{Mn}$ e $\mathrm{Zn}$ nas folhas diagnóstico de todas as progênies estavam dentro das faixas ditas como adequadas para o crescimento do E. grandis, segundo Dell et al. (1995), Boardman et al.(1997) e Silveira et al. (1999). A única exceção foi o ferro, cujas as concentrações obtidas estavam adequadas somente de acordo com Boardman et al. (1997), cuja a faixa está entre 50 e $156 \mathrm{mg} \mathrm{de} \mathrm{Fe} \mathrm{kg}^{-1}$. No entanto, pelos outros autores, as concentrações obtidas nas progênies 1,2 e 3 estavam abaixo da faixa adequada, que varia de 63 a $128 \mathrm{mg}$ de Fe kg $^{-1}$ (Dell et al., 1995; Silveira et al., 1999).

A concentração de $\mathrm{B}, \mathrm{Cu}, \mathrm{Fe}$ e $\mathrm{Mn}$ nos ramos diferiu em função do material genético (Tabela 24). Para o boro, a progênie 1 apresentou valor mais elevado em relação as progênies 3 e 4 . A concentração de cobre foi mais alta nas progênies 3 e 4 quando comparadas com a progênie 2 . Já em relação a concentração de ferro, verificouse que a progênie 2 foi superior as demais. A única diferença observada para manganês foi entre as progênies 2 e 3, com maior concentração na primeira.

Não foi observada diferença entre os materiais genéticos para a concentração de ferro na casca (Tabela 24). Para o boro, menor concentração foi constatada na progênie 2 quando comparada com as progênies 1 e 4 . A única diferença para a concentração de cobre na casca ocorreu entre as progênies 1 e 4 , com superioridade da última. Em relação ao manganês, a progênie 2 apresentou concentração mais alta que a progênie 3. A progênie 4 apresentou maior concentração de zinco somente quando comparada com a progênie 1 .

Os materiais genéticos diferiram quanto a concentração dos micronutrientes no lenho (Tabela 24). A maior concentração de boro foi observada na progênie 1, que diferiu estatisticamente da progênie 4 . Houve também diferença para a concentração de cobre, sendo que a progênie 1 foi superior as progênies 3 e 4 . Em relação ao ferro, as concentrações mais altas foram verificadas nas progênies 1 e 2 , as quais diferiram da progênie 3. Apesar das pequenas variações da concentração de zinco no lenho, as progênies 1 e 4 apresentaram maior teor em relação as progênies 2 e 3 . 
Tabela 23. Concentração de $\mathrm{B}, \mathrm{Cu}, \mathrm{Fe}, \mathrm{Mn}$ e $\mathrm{Zn}$ nas folhas novas, velhas e diagnóstico das progênies de Eucalyptus grandis.

\begin{tabular}{lccccc}
\hline \hline Material genético & $\mathrm{B}$ & $\mathrm{Cu}$ & $\mathrm{Fe}$ & $\mathrm{Mn}$ & $\mathrm{Zn}$ \\
\cline { 2 - 6 } & \multicolumn{5}{c}{$\mathrm{mg} \mathrm{kg}^{-1}$} \\
\hline Progênie 1 & $29 \mathrm{a}$ & $9 \mathrm{a}$ & $86 \mathrm{a}$ & $707 \mathrm{~b}$ & $45 \mathrm{a}$ \\
Progênie 2 & $30 \mathrm{a}$ & $6 \mathrm{~b}$ & $84 \mathrm{ab}$ & $896 \mathrm{a}$ & $35 \mathrm{~b}$ \\
Progênie 3 & $30 \mathrm{a}$ & $6 \mathrm{~b}$ & $70 \mathrm{~b}$ & $818 \mathrm{a}$ & $34 \mathrm{~b}$ \\
Progênie 4 & $30 \mathrm{a}$ & $4 \mathrm{c}$ & $72 \mathrm{ab}$ & $653 \mathrm{~b}$ & $30 \mathrm{~b}$ \\
\hline Média & 29,7 & 6,2 & 78,0 & 768,5 & 36,0 \\
\hline & & \multicolumn{5}{c}{ Folhas velhas } \\
\hline Progênie 1 & $31 \mathrm{a}$ & $8 \mathrm{a}$ & $96 \mathrm{a}$ & $921 \mathrm{a}$ & $40 \mathrm{a}$ \\
Progênie 2 & $28 \mathrm{a}$ & $5 \mathrm{~b}$ & $82 \mathrm{ab}$ & $867 \mathrm{a}$ & $28 \mathrm{~b}$ \\
Progênie 3 & $28 \mathrm{a}$ & $5 \mathrm{~b}$ & $67 \mathrm{~b}$ & $861 \mathrm{a}$ & $29 \mathrm{~b}$ \\
Progênie 4 & $30 \mathrm{a}$ & $4 \mathrm{~b}$ & $77 \mathrm{~b}$ & $545 \mathrm{~b}$ & $26 \mathrm{~b}$ \\
\hline Média & 29,2 & 5,5 & 80,5 & 798,5 & 30,7 \\
\hline & & \multicolumn{5}{c}{ Folhas diagnóstico } \\
\hline Progênie 1 & $29 \mathrm{~b}$ & $9 \mathrm{a}$ & $56 \mathrm{ab}$ & $600 \mathrm{a}$ & $24 \mathrm{~b}$ \\
Progênie 2 & $30 \mathrm{ab}$ & $7 \mathrm{~b}$ & $51 \mathrm{~b}$ & $500 \mathrm{a}$ & $27 \mathrm{ab}$ \\
Progênie 3 & $31 \mathrm{ab}$ & $7 \mathrm{~b}$ & $52 \mathrm{~b}$ & $535 \mathrm{a}$ & $30 \mathrm{a}$ \\
Progênie 4 & $32 \mathrm{a}$ & $8 \mathrm{ab}$ & $66 \mathrm{a}$ & $515 \mathrm{a}$ & $30 \mathrm{a}$ \\
\hline Média & 30,5 & 7,7 & 56,2 & 537,5 & 27,7 \\
\hline \hline
\end{tabular}

Médias seguidas de mesma letra não diferem entre si pelo teste de Tukey ao nivel de $5 \%$ de probabilidade.

\subsubsection{Efeito das doses de potássio sobre a concentração dos micronutrientes}

Na Tabela 25 são apresentados os coeficientes de correlações de Pearson entre as doses de potássio na solução e a concentração dos micronutrientes nas diferentes partes das plantas. A concentração de cobre nas folhas diminuiu com o aumento da dose de potássio, sendo mais marcante nas folhas novas. Resultados similares foram encontrados para o zinco nas folhas novas e diagnóstico. Considerando todas as progênies, não houve efeito da dose sobre a concentração de ferro nas várias partes da planta, com exceção das progênies 2 e 3 para as folhas novas e a casca, respectivamente. Os efeitos da dose de $\mathrm{K}$ sobre a concentração de $\mathrm{Mn}$ foram bastante pronunciados nas folhas velhas de todas as progênies. A concentração de $\mathrm{Mn}$ decrescia a medida que aumentava-se a adição de $\mathrm{K}$. Em relação a o boro, os dados foram bastante consistente 
para a concentração nas folhas diagnóstico, casca e lenho. Verificou-se que aumentos da concentração de boro nas folhas diagnóstico e na casca ocorreram com a elevação da dose de $\mathrm{K}$, efeitos opostos foram verificados no lenho.

Tabela 24. Concentração de $\mathrm{B}, \mathrm{Cu}, \mathrm{Fe}, \mathrm{Mn}$ e $\mathrm{Zn}$ nos ramos, casca e lenho das progênies de Eucalyptus grandis.

\begin{tabular}{llllll}
\hline \hline Material genético & $\mathrm{B}$ & $\mathrm{Cu}$ & $\mathrm{Fe}$ & $\mathrm{Mn}$ & $\mathrm{Zn}$ \\
\cline { 2 - 6 } & \multicolumn{5}{c}{$\mathrm{mg} \mathrm{kg}^{-1}$} \\
\hline Progênie 1 & $13 \mathrm{a}$ & $7 \mathrm{ab}$ & $46 \mathrm{~b}$ & $49 \mathrm{ab}$ & $15 \mathrm{a}$ \\
Progênie 2 & $11 \mathrm{ab}$ & $6 \mathrm{~b}$ & $65 \mathrm{a}$ & $54 \mathrm{a}$ & $16 \mathrm{a}$ \\
Progênie 3 & $9 \mathrm{~b}$ & $8 \mathrm{a}$ & $41 \mathrm{~b}$ & $41 \mathrm{~b}$ & $16 \mathrm{a}$ \\
Progênie 4 & $9 \mathrm{~b}$ & $8 \mathrm{a}$ & $46 \mathrm{~b}$ & $45 \mathrm{ab}$ & $17 \mathrm{a}$ \\
\hline Média & 10,5 & 7,2 & 49,5 & 47,2 & 16,0 \\
\hline & & \multicolumn{5}{c}{ Casca } & \\
\hline Progênie 1 & $22 \mathrm{a}$ & $14 \mathrm{~b}$ & $31 \mathrm{a}$ & $135 \mathrm{ab}$ & $13 \mathrm{~b}$ \\
Progênie 2 & $17 \mathrm{~b}$ & $16 \mathrm{ab}$ & $31 \mathrm{a}$ & $141 \mathrm{a}$ & $15 \mathrm{ab}$ \\
Progênie 3 & $19 \mathrm{ab}$ & $16 \mathrm{ab}$ & $32 \mathrm{a}$ & $116 \mathrm{~b}$ & $15 \mathrm{ab}$ \\
Progênie 4 & $21 \mathrm{a}$ & $17 \mathrm{a}$ & $33 \mathrm{a}$ & $129 \mathrm{ab}$ & $17 \mathrm{a}$ \\
\hline Média & 19,7 & 15,7 & 31,7 & 130,2 & 15,0 \\
\hline & & \multicolumn{5}{c}{ Lenho } & \\
\hline Progênie 1 & $9,3 \mathrm{a}$ & $9 \mathrm{a}$ & $23 \mathrm{a}$ & $95 \mathrm{a}$ & $6 \mathrm{a}$ \\
Progênie 2 & $8,4 \mathrm{ab}$ & $8 \mathrm{ab}$ & $23 \mathrm{a}$ & $84 \mathrm{ab}$ & $5 \mathrm{~b}$ \\
Progênie 3 & $8,7 \mathrm{ab}$ & $6 \mathrm{~b}$ & $17 \mathrm{~b}$ & $74 \mathrm{ab}$ & $5 \mathrm{~b}$ \\
Progênie 4 & $8,1 \mathrm{~b}$ & $7 \mathrm{~b}$ & $18 \mathrm{ab}$ & $64 \mathrm{~b}$ & $6 \mathrm{a}$ \\
\hline Média & 8,6 & 7,5 & 20,2 & 79,2 & 5,5 \\
\hline \hline
\end{tabular}

Médias seguidas de mesma latra não diferem entre si pelo teste de Tukey ao nivel de $5 \%$ de probabilidade.

Existem poucos estudos mostrando o efeito da aplicação de $\mathrm{K}$ sobre a concentração de micronutrientes em Eucalyptus. Dentre estes, Schonau (1981) verificou que a concentração de $\mathrm{Zn}$ e $\mathrm{Fe}$ nas folhas de E. grandis decrescia com o maior suprimento de K. Resultados similares foram obtidos neste estudo em relação ao zinco. Porém, pouca influência do potássio em relação ao ferro. 
Tabela 25. Coeficientes de correlações de Pearson entre as doses de potássio na solução nutritiva e a concentração dos micronutrientes nas partes das plantas das progênies de Eucalyptus grandis.

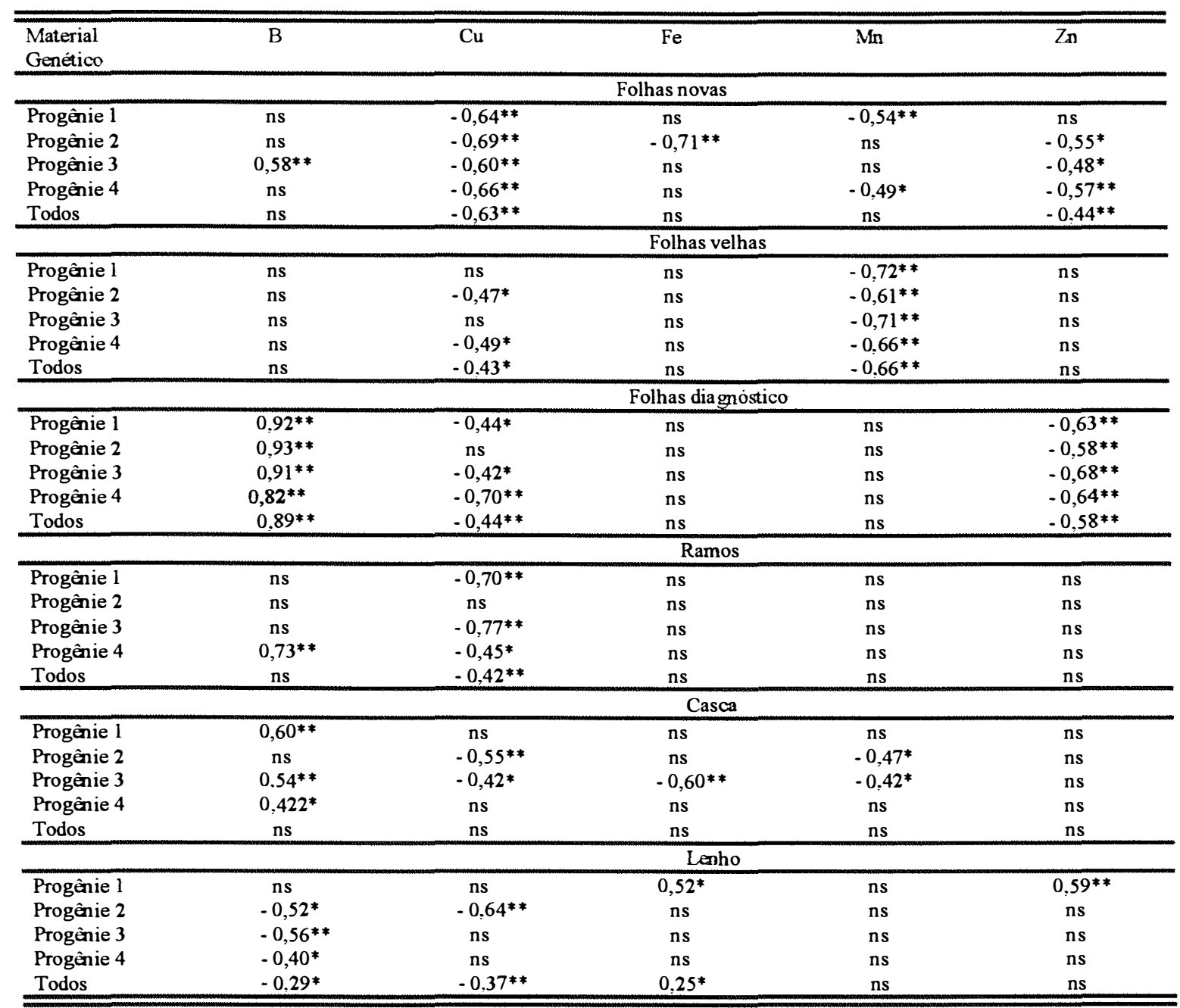

** - significativo a $1 \%$ de probabilidade; * - significativo a $5 \%$ de probabilidade; ns - năo significativo.

\subsubsection{Relação entre a concentração de potássio nos tecidos vegetais e a}

\section{produção de matéria seca lenhosa e total}

Através das equações de regressões determinaram-se as concentrações nos tecidos foliares associadas a máxima produção, nível crítico ( $90 \%$ da produção relativa) e zona de desequilíbrio (Tabelas 26 e 27). 
As Tabelas 28 e 29 mostram as equações de regressões entre as concentrações de $\mathrm{K}$ nos ramos, casca e lenho e a produção de matéria seca total e lenhosa, respectivamente.

Tabela 26. Equações de regressões entre a produção de matéria seca total e a concentração de potássio nas folhas novas, velhas e diagnóstico das progênies de Eucalyptus grandis.

\begin{tabular}{|c|c|c|c|c|c|}
\hline \multirow{2}{*}{$\begin{array}{l}\text { Material } \\
\text { genético }\end{array}$} & \multirow[t]{2}{*}{ Equação } & \multirow{2}{*}{$\begin{array}{c}\text { Máxima } \\
\text { produção } \\
\text { (g/planta) }\end{array}$} & \multicolumn{3}{|c|}{$\overline{\mathrm{K} \text { nas folhas }\left(\mathrm{g} \mathrm{kg}^{-1}\right)}$} \\
\hline & & & M.P.' & N.C. ${ }^{2}$ & Z.D. ${ }^{3}$ \\
\hline \multicolumn{6}{|c|}{ Folhas novas } \\
\hline Progênie 1 & \multicolumn{5}{|c|}{ Não significativo } \\
\hline Progênie 2 & $y=336,56+22,532 x-0.8974 x^{2} \quad R^{2}=0,56^{* *}$ & $478(102)$ & $12.5(119)$ & $5,2(349)$ & $>19,9(100)$ \\
\hline Progênie 3 & $y=231,78+38,500 x-1,2689 x^{2} \quad R^{2}=0,80^{* *}$ & $520(111)$ & $15,2(148)$ & $8,5(569)$ & $>21,8(109)$ \\
\hline Progênie 4 & $y=432,42+6,820 x-0,3238 x^{2} \quad R^{2}=0,70^{* *}$ & $468(100)$ & $10,5(100)$ & $1,5(100)$ & $>22,6(113)$ \\
\hline \multicolumn{6}{|c|}{ Folhas velhas } \\
\hline \multicolumn{6}{|c|}{ Não significativo } \\
\hline Progênie 2 & $y=378,07+23,751 x-1,4451 x^{2} \quad R^{2}=0,45 * *$ & $476(101)$ & $8,2(139)$ & $2,5(166)$ & $>13,9(113)$ \\
\hline Progênie 3 & $y=232,71+66,846 x-3,8640 x^{2} \quad R^{2}=0,75 * *$ & $522(111)$ & $8,6(146)$ & $5,0(333)$ & $>12,3(100)$ \\
\hline Progênie 4 & $\mathrm{y}=439,31+9,957 \mathrm{x}-0,8366 \mathrm{x}^{2} \quad \mathrm{R}^{2}=0,65 * *$ & $+69(100)$ & $5,9(100)$ & $1,5(100)$ & $>13,4(109)$ \\
\hline \multicolumn{6}{|c|}{ Folhas diagnóstico } \\
\hline \multicolumn{6}{|c|}{ Não significativo } \\
\hline Progênie 2 & $y=378,98+22,364 x-1,2043 x^{2} \quad R^{2}=0,53^{* *}$ & $483(100)$ & $9,3(104)$ & $3,0(100)$ & $>15,6(105)$ \\
\hline Progênie 3 & $y=299,94+43,192 x-2,0328 x^{2} \quad R^{2}=0,76^{* *}$ & $529(109)$ & $10.6(119)$ & $5,5(183)$ & $>15,9(107)$ \\
\hline Progênie 4 & $y=385,67+25,532 x-1,4277 x^{2} \quad R^{2}=0,81^{* *}$ & $499(103)$ & $8,9(100)$ & $3,0(100)$ & $>14,9(100)$ \\
\hline
\end{tabular}

(1) - máxima produção; (2) - nivel crítico: $90 \%$ da máxima produção; (3) - zona de desequilibrio. Os valores entre parênteses são referentes as diferenças percentuais em relação aos materiais genéticos. 
Tabela 27. Equações de regressões entre a produção de matéria seca lenhosa e a concentração de potássio nas folhas novas, velhas e diagnóstico das progênies de Eucalyptus grandis.

\begin{tabular}{|c|c|c|c|c|c|}
\hline \multirow{2}{*}{$\begin{array}{l}\text { Material } \\
\text { genético }\end{array}$} & \multirow[t]{2}{*}{ Equação } & \multirow{2}{*}{$\begin{array}{l}\text { Máxima } \\
\text { produção } \\
\text { (g/planta) }\end{array}$} & \multicolumn{3}{|c|}{ K nas folhas $\left(\mathrm{g} \mathrm{kg}^{-1}\right)$} \\
\hline & & & M.P. ${ }^{1}$ & N.C. ${ }^{2}$ & Z.D. ${ }^{3}$ \\
\hline \multicolumn{6}{|c|}{ Folhas novas } \\
\hline Progênie 1 & \multicolumn{5}{|c|}{ Não significativo } \\
\hline Progênie 2 & $y=91,152+8,713 x-0,3339 x^{2} \quad R^{2}=0,45^{* *}$ & $148(102)$ & $13,0(119)$ & $6,4(349)$ & $>19,7(100)$ \\
\hline Progênie 3 & $y=60,660+18,319 x-0,5957 x^{2} \quad R^{2}=0,66^{* *}$ & $202(111)$ & $15,4(148)$ & $9,6(569)$ & $>21,2(109)$ \\
\hline Progênie 4 & $y=136,162+4,403 x-0,1902 x^{2} \quad R^{2}=0,63^{* *}$ & $162(100)$ & $11,6(100)$ & $2,4(100)$ & $>20,7(113)$ \\
\hline \multicolumn{6}{|c|}{ Folhas velhas } \\
\hline \multicolumn{6}{|c|}{ Não significativo } \\
\hline Progênie 2 & $y=104,521+10,265 x-0,5971 x^{2} R^{2}=0,43^{* *}$ & $149(101)$ & $8,6(139)$ & $3,7(166)$ & $>13,5(113)$ \\
\hline Progênie 3 & $y=58,295+32,488 x-1,8393 x^{2} \quad R^{2}=0,65 * *$ & $202(111)$ & $8,8(146)$ & $5,5(333)$ & $>12,1(100)$ \\
\hline Progênie 4 & $y=138,819+7,057 x-0,5222 x^{2} \quad R^{2}=0,65 * *$ & $165(100)$ & $6,7(100)$ & $1,6(100)$ & $>12,0(109)$ \\
\hline \multicolumn{6}{|c|}{ Folhas diagnóstico } \\
\hline \multicolumn{6}{|c|}{ Não significativo } \\
\hline Progênie 2 & $y=103,790+10,525 x-0,5507 x^{2} R^{2}=0,74^{* *}$ & $154(100)$ & $9,5(110)$ & $4,2(131)$ & $>14,9(106)$ \\
\hline Progênie 3 & $y=84,013+23,491 x-1,0841 x^{2} \quad R^{2}=0,77^{* *}$ & $211(137)$ & $10,8(126)$ & $6,4(200)$ & $>15,3(109)$ \\
\hline Progênie 4 & $y=127,800+10,181 x-0,5921 x^{2} R^{2}=0,56^{* *}$ & $171(111)$ & $8,6(100)$ & $3,2(100)$ & $>14,0(100)$ \\
\hline
\end{tabular}

(1) - máxima produção; (2) - nível crítico: $90 \%$ da máxima produção; (3) - zona de desequilibrio. Os valores entre parênteses são referentes as diferenças percentuais em relação aos materiais genéticos. 
Tabela 28. Equações de regressões entre a produção de matéria seca total e a concentração de potássio nos ramos, casca e lenho das progênies de Eucalyptus grandis.

\begin{tabular}{|c|c|c|c|c|c|}
\hline \multirow{2}{*}{$\begin{array}{l}\text { Material } \\
\text { genético }\end{array}$} & \multirow[t]{2}{*}{ Equação } & \multirow{2}{*}{$\begin{array}{l}\text { Máxima } \\
\text { produção } \\
\text { (g/planta) }\end{array}$} & \multicolumn{3}{|c|}{$\overline{\mathrm{K} \text { no tecido }\left(\mathrm{g} \mathrm{kg}^{-1}\right)}$} \\
\hline & & & M.P. ${ }^{1}$ & N.C. ${ }^{2}$ & Z.D. ${ }^{3}$ \\
\hline \multicolumn{6}{|c|}{ Ramos } \\
\hline Progênie 1 & \multicolumn{5}{|c|}{ Não significativo } \\
\hline Progênie 2 & $y=348,21+103,866 x-21,207 x^{2} \quad R^{2}=0,44^{* *}$ & $475(100)$ & $2,44(118)$ & $0,95(161)$ & $3,94(112)$ \\
\hline Progênie 3 & $y=283,35+141,727 x-25,360 x^{2} R^{2}=0,49^{* *}$ & $481(101)$ & $2,79(135)$ & $1,42(241)$ & $4,17(118)$ \\
\hline Progênie 4 & $y=320,01+131,234 x-26,583 x^{2} R^{2}=0,76^{* *}$ & $482(101)$ & $2,06(100)$ & $0,59(100)$ & $3,53(100)$ \\
\hline \multicolumn{6}{|c|}{ Casca } \\
\hline \multicolumn{6}{|c|}{ Não significativo } \\
\hline Progênie 2 & $y=320,01+131,234 x-26,583 x^{2} \quad R^{2}=0,76^{* *}$ & $482(100)$ & $2,47(100)$ & $1,12(100)$ & $3,81(102)$ \\
\hline Progênie 3 & $y=178,79+233,671 x-43,714 x^{2} \quad R^{2}=0.58^{* *}$ & $491(102)$ & $2,67(108)$ & $1,61(144)$ & $3,73(100)$ \\
\hline \multirow{2}{*}{\multicolumn{6}{|c|}{ Não significativo }} \\
\hline & & & & & \\
\hline \multicolumn{6}{|c|}{ Não significativo } \\
\hline Progênie 2 & $y=347,08+111,935 x-21,470 x^{2} \quad R^{2}=0,52^{* *}$ & $493(100)$ & $2,60(100)$ & $1,09(100)$ & $4,12(108)$ \\
\hline Progênie 3 & $y=233,82+215,032 x-40,024 x^{2} R^{2}=0,81^{* *}$ & $523(106)$ & $2,69(103)$ & $1,55(142)$ & $3,82(100)$ \\
\hline Progênie 4 & \multicolumn{5}{|c|}{ Não significativo } \\
\hline
\end{tabular}

(1) - máxima produção; (2) - nível crítico: $90 \%$ da máxima produção; (3) - zona de desequilibrio. Os valores entre parênteses são referentes as diferenças percentuais em relação aos materiais genéticos. 
Tabela 29. Equações de regressões entre a produção de matéria seca lenhosa e a concentração de potássio nos ramos, casca e lenho das progênies de Eucalyptus grandis.

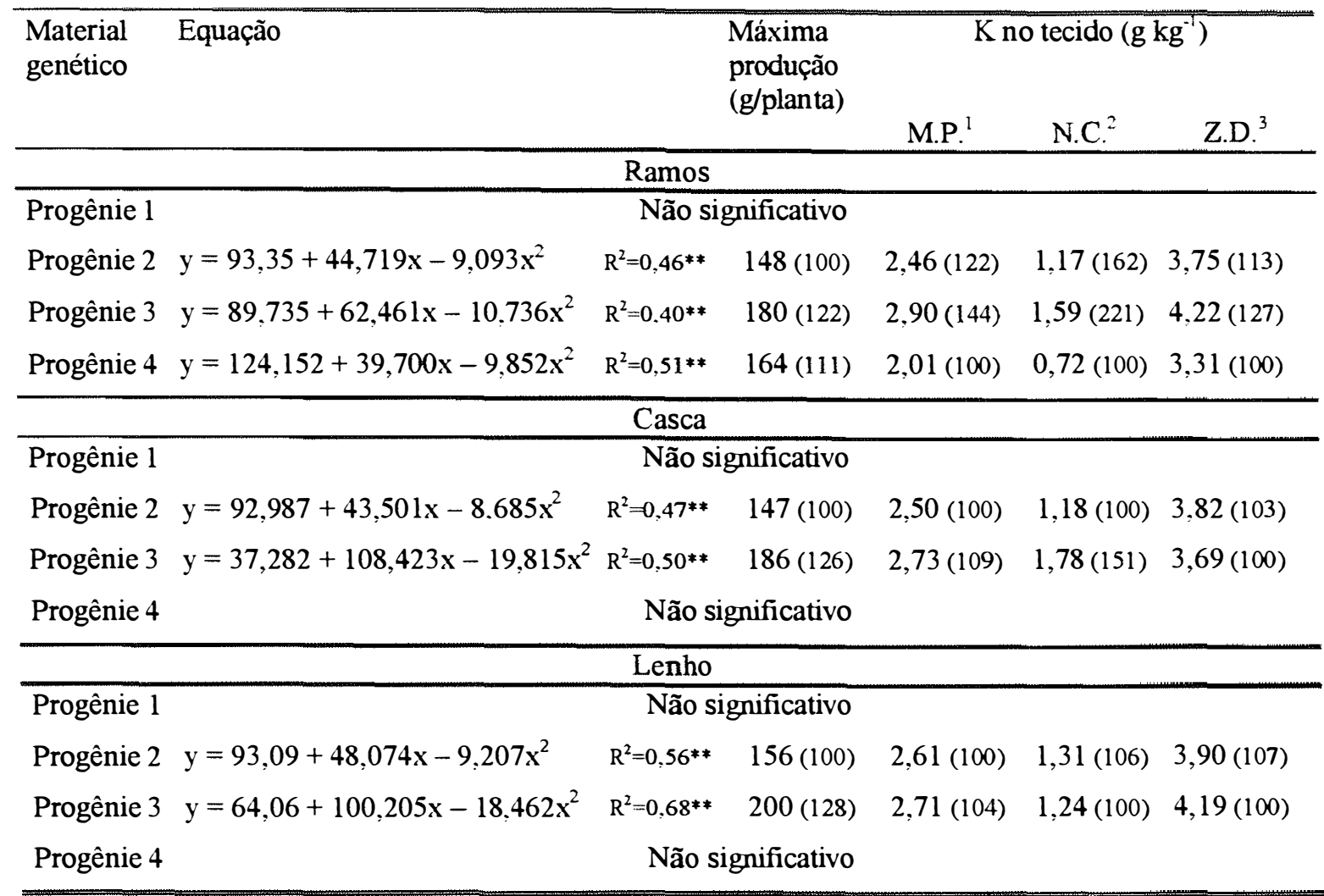

(1)- máxima produção; (2)- nível critico: $90 \%$ da máxima produção; (3)-zona de desequilíbrio. Os valores entre parênteses são referentes as diferenças percentuais em relação aos materiais genéticos.

Os materiais genéticos responderam de maneira diferenciada na produção de matéria seca lenhosa em função da variação das concentrações de $\mathrm{K}$ nas folhas diagnóstico (Figura 16). A progênie 1 apresentou pequena variação na produção quando a concentração de $\mathrm{K}$ nas folhas variou de 2 a $21 \mathrm{~g} \mathrm{~kg}^{-1}$. Esse material genético foi considerado pouco exigente, como também, tolerante à concentrações mais elevadas de $\mathrm{K}$ no tecido foliar. Efeitos contrários foram observados para as progênies 2 e 3. Já a progênie 4 , foi considerada de baixa exigência em potássio, mas não tolerante a altas concentrações de $\mathrm{K}$ nas folhas. Os resultados obtidos confirmaram as observações 
preliminares feitas em condições de campo sendo as progênies 1 e 4 consideradas de baixa exigência em potássio, enquanto que a progênies 2 e 3 exigentes em potássio ${ }^{1}$.

A máxima produção de matéria seca lenhosa para as progênies 2, 3 e 4 foram obtidas quando as plantas apresentavam concentrações foliares de 9,5, 10,8 e 8,6 g de K $\mathrm{kg}^{-1}$, respectivamente (Figura 16). O nível para obtenção de $90 \%$ da máxima produção foi bastante diferente entre os materiais genéticos, sendo de: $6,4 \mathrm{~g} \mathrm{~kg}^{-1}$ para a progênie 3 , $4,2 \mathrm{~g} \mathrm{~kg}^{-1}$ para a progênie 2 e de $3,1 \mathrm{~g} \mathrm{~kg}^{-1}$ para a progênie 4 . A faixa adequada de $\mathrm{K}$ nas folhas diagnóstico das progênies 3, 2, 4 e 1 foram, respectivamente de: 6,4 a $15,3 \mathrm{~g} \mathrm{~kg}^{-1}$; 4,2 a $14,9 \mathrm{~g} \mathrm{~kg}^{-1} ; 3,1$ a $14 \mathrm{~g} \mathrm{~kg}^{-1}$ e 2,0 a $22 \mathrm{~g} \mathrm{~kg}^{-1}$. Comparando as faixas adequadas de $\mathrm{K}$ obtidas com as propostas como adequadas para espécies de Eucalyptus, constatou-se que os limites inferiores estavam bem abaixo dos encontrados em E. grandis - 12 a $24 \mathrm{~g} \mathrm{~kg}^{-1}$ (Dell et al., 1995), E. pellita - 9 a $15 \mathrm{~g} \mathrm{~kg}^{-1}$ (Dell et al, 1995), E. urophylla - 8 a $14 \mathrm{~g} \mathrm{~kg}$ ${ }^{1}$ (Boardman et al. (1997), E. globulus - 8 a $12 \mathrm{~g} \mathrm{~kg}^{-1}$ (Boardman et al. (1997), E. saligna $-8,5$ a $10 \mathrm{~g} \mathrm{~kg}^{-1}$ (Silveira et al., 1998), E. urophylla - 8 a $14 \mathrm{~g} \mathrm{~kg}^{-1}$ (Dell et al, 1995) e E. dunnii - 8 a $15 \mathrm{~g} \mathrm{~kg}^{-1}$ (Boardman et al., 1997). No entanto, Novais et al. (1980) determinaram que a faixa adequada para mudas de $E$. grandis situava-se entre 3,1 a $8,1 \mathrm{~g}$ de $\mathrm{K} \mathrm{kg}^{-1}$, valores mais próximos aos encontrados neste estudo. Os valores de potássio considerados adequados para $E$. pilularis na fase juvenil $\left(3,5\right.$ a $\left.5,0 \mathrm{~g} \mathrm{~kg}^{-1}\right)$ por Cromer et al. (1981), E, globulus adulto $\left(5\right.$ a $\left.12 \mathrm{~g} \mathrm{~kg}^{-1}\right) e E$. grandis adulto $\left(6\right.$ a $\left.18 \mathrm{~g} \mathrm{~kg}^{-1}\right)$ por Boardman et al. (1997) foram análogos aos obtidos no presente estudo.

Uma das explicações para as concentrações adequadas de $\mathrm{K}$ serem menores que as obtidas em outros trabalhos, seria que as progênies provenientes da região de Itatinga/SP foram selecionadas em solos arenosos com baixos teores de $\mathrm{K}$ trocável $(0,2$ a $0,6 \mathrm{mmol}_{\mathrm{c}} \mathrm{dm}^{-3}$ ).

A Figura 17 mostra a relação entre a concentração de potássio nas folhas diagnóstico e a produção de matéria seca total. As tendências foram as mesmas observadas para a produção de lenho, exceto a progênie 1, que apresentou quedas lineares em função da dose de $\mathrm{K}$ na solução nutritiva. As quedas na MS total desse genótipo foram ocasionadas pela redução na produção de folhas e ramos.

1-Comunicaçāo pessoal do Eng. Shinitiro Oda da Companhia Suzano de Papel e Celulose 
Progênie 1

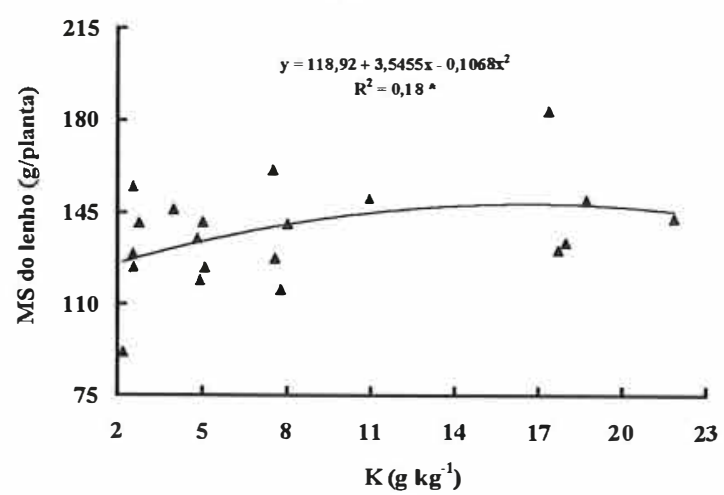

Progênie 3

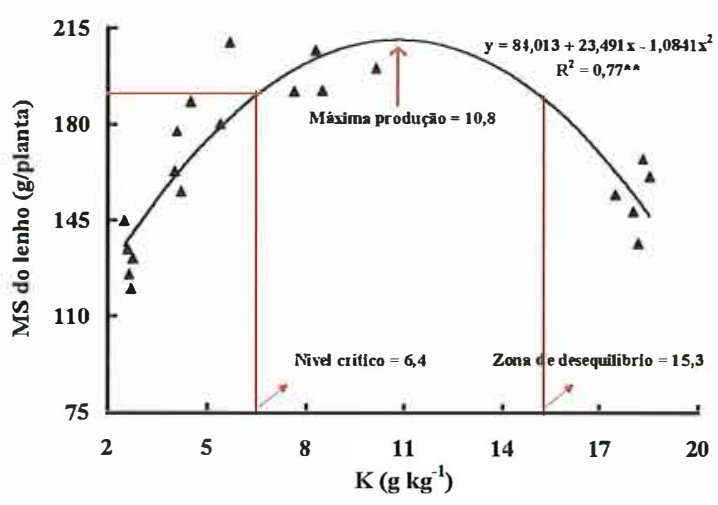

Progênie 2

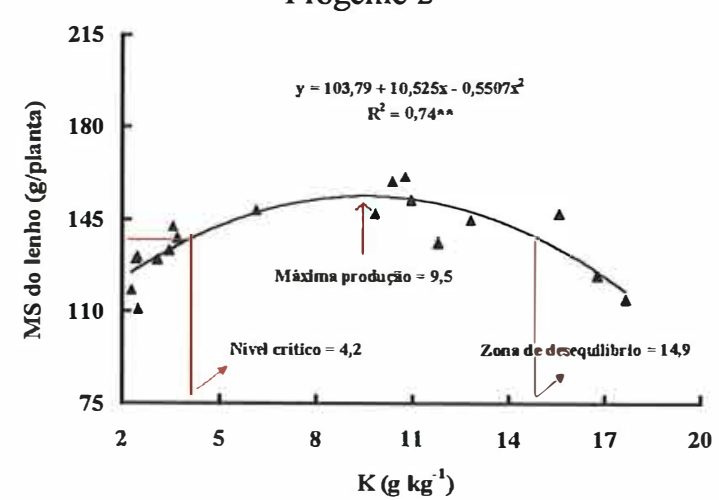

Progênie 4

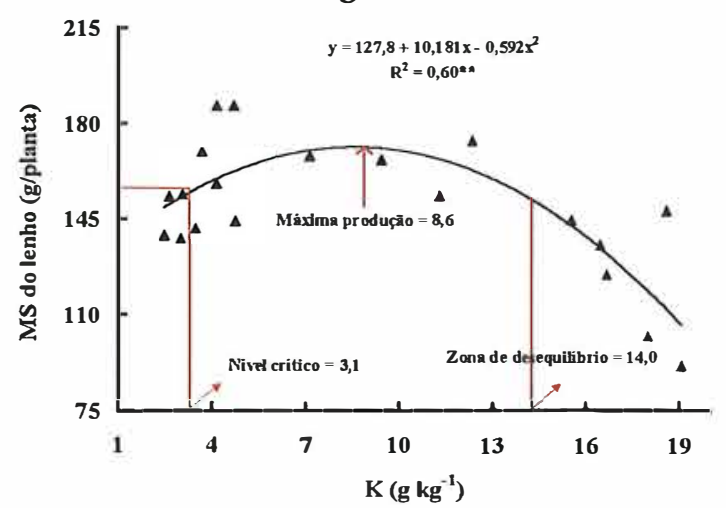

Figura 16. Produção de matéria seca lenhosa das progênies de Eucalyptus grandis em função da concentração de potássio nas folhas diagnóstico. 
Progênie 1

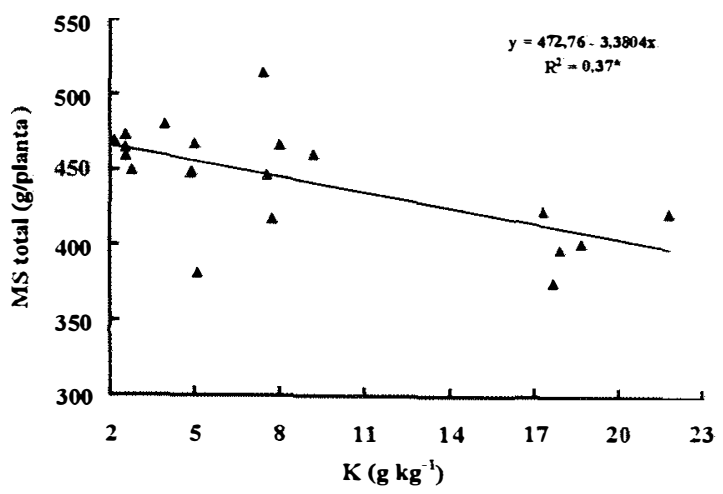

Progênie 3

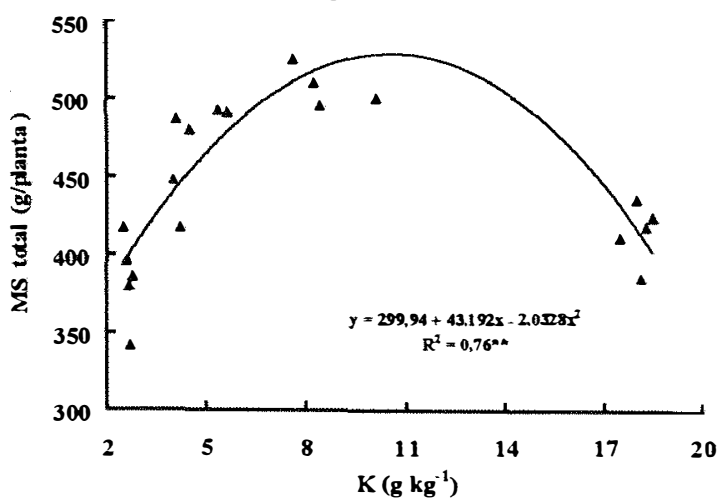

Progênie 2

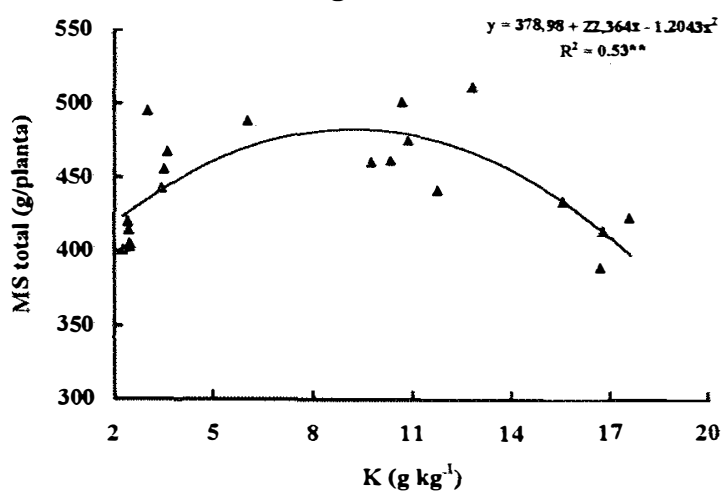

Progênie 4

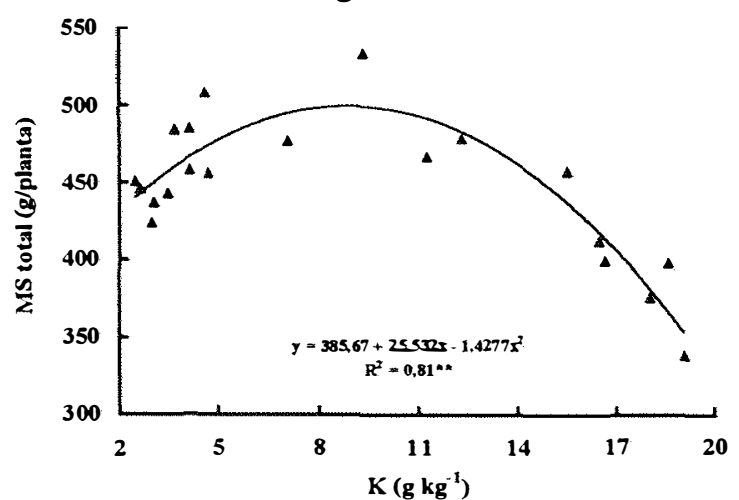

Figura 17. Produção de matéria seca total das progênies de Eucalyptus grandis em função da concentração de potássio nas folhas diagnóstico. 


\subsubsection{Relação entre $\mathrm{N} / \mathrm{K}, \mathrm{K} / \mathrm{P}, \mathrm{K} / \mathrm{Ca}, \mathrm{K} / \mathrm{Mg}, \mathrm{K} / \mathrm{Ca}+\mathrm{Mg}$ nas folhas diagnóstico e a produção de matéria seca lenhosa}

Os efeitos da relação $\mathrm{N} / \mathrm{K}$ nas folhas diagnóstico sobre a produção de lenho mostraram que não houve relação significativa para as progênies 1 e 2 (Figura 18). A máxima produção foi obtida quando a relação $\mathrm{N} / \mathrm{K}$ foi de 4,2 para a progênie 3 e 5,5 para a progênie 4 . $O$ nível crítico da razão $N / K$ nas folhas das progênies 3 e 4 foi de 1,6 e 2,7 , respectivamente. Ocorreu quedas na produtividade quando a razão $N / K$ nas folhas foi maior que 6,8 para a progênie 3 e 8,3 para a progênie 4. Herbert (1996) constatou que a relação $\mathrm{N} / \mathrm{K}$ considerada adequada para o crescimento do E. grandis foi de 3,5, valor abaixo dos obtidos para a produção máxima neste estudo.

As progênies 2, 3 e 4 apresentaram respostas na produção de lenho conforme a razão K/P nas folhas diagnóstico (Figura 19). As variações de produção para a progênie 2 foram pequenas quando comparadas as progênies 3 e 4 . As progênies 2,3 e 4 apresentaram máxima produção quando as suas plantas tinham no tecido foliar razões $\mathrm{K} / \mathrm{P}$ de $7,6,8,6$ e 5,8 respectivamente. Verifica-se que para alcançar $90 \%$ da máxima produção, a relação foi de $2,5 \mathrm{~K} / 1 \mathrm{P}$ na progênie 2 e $3,7 \mathrm{~K} / 1 \mathrm{P}$ na progênie 3 . Independente do material genético, razões foliares acima de $10 \mathrm{~K} / 1 \mathrm{P}$ provocaram decréscimos na produtividade. Herbert (1996) relata que a razão foliar K/P ótima para o desenvolvimento do $E$. grandis estava em torno de 5, valor abaixo do encontrado para máxima produção das progênies neste trabalho. 
Progênie 1

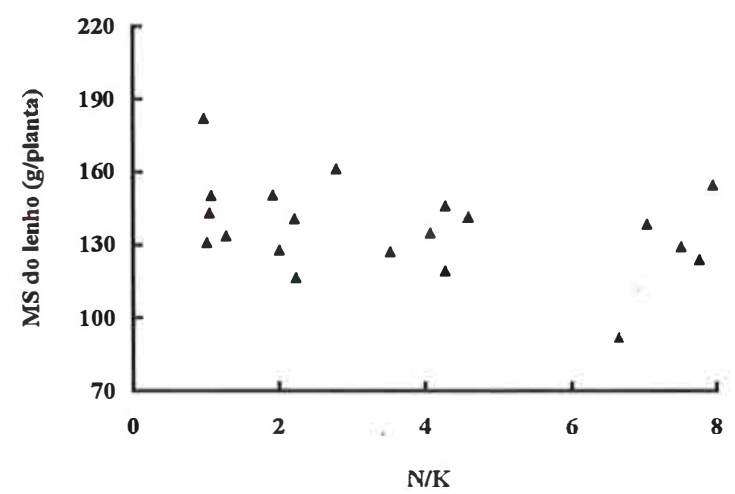

Progênie 3

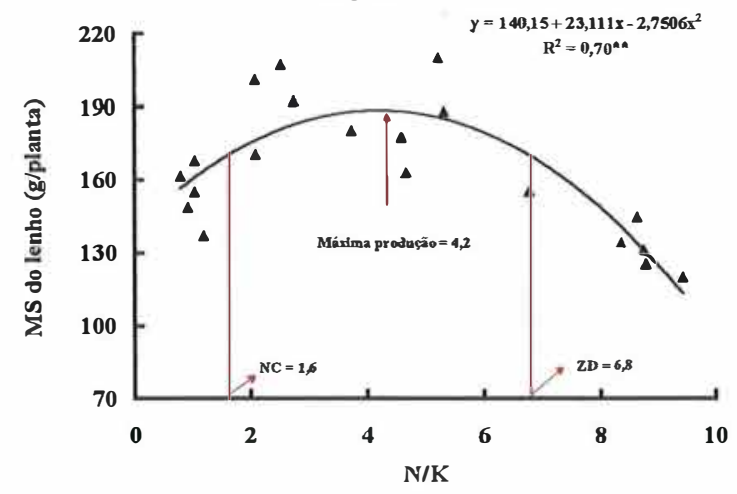

Progênie 2

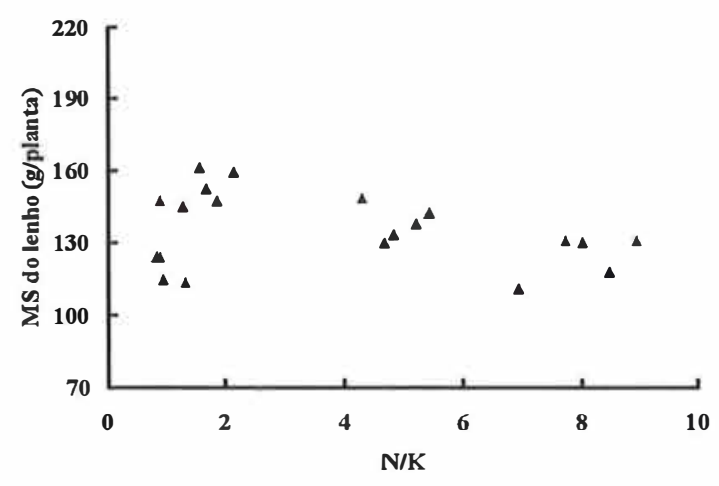

Progênie 4

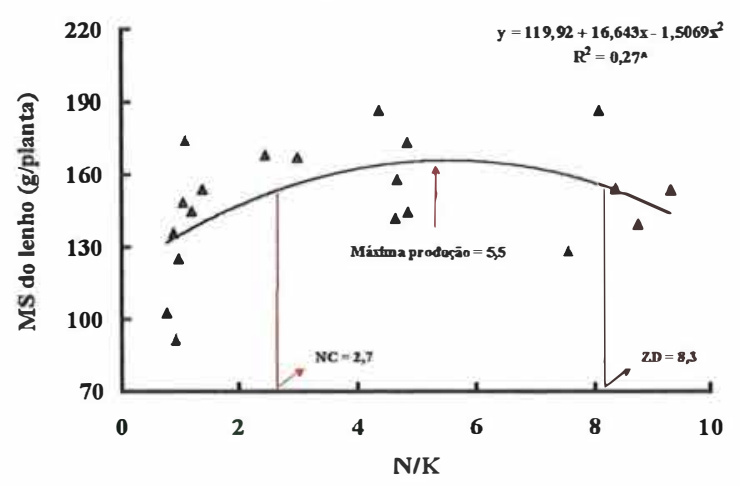

Figura 18. Produção de matéria seca lenhosa das progênies de Eucalyptus grandis em função da razão N/K nas folhas diagnóstico. 
Progênie 1

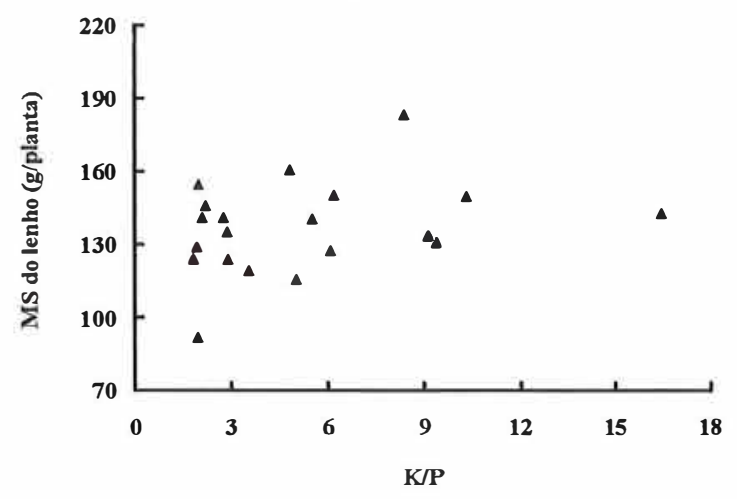

Progênie 3

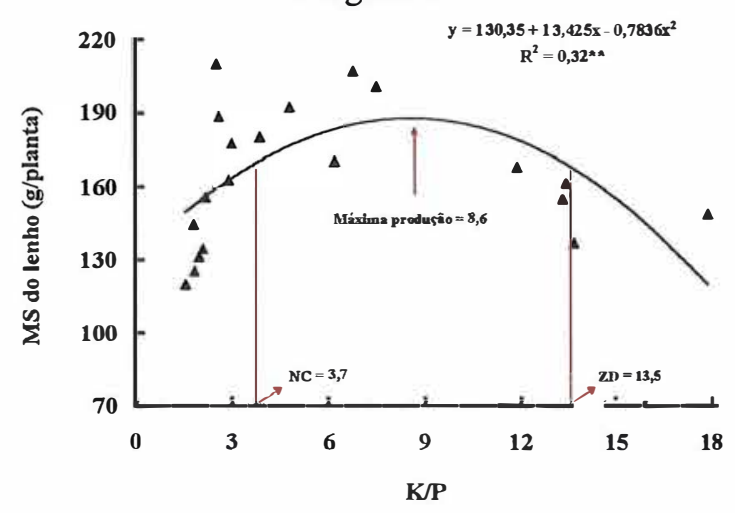

Progênie 2

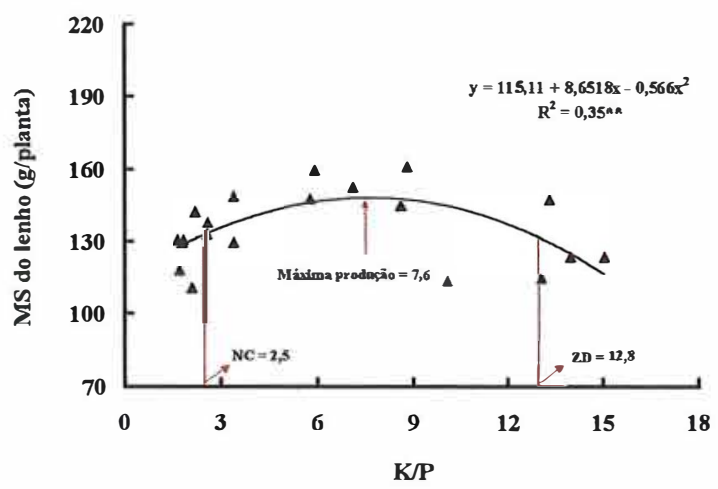

Progênie 4

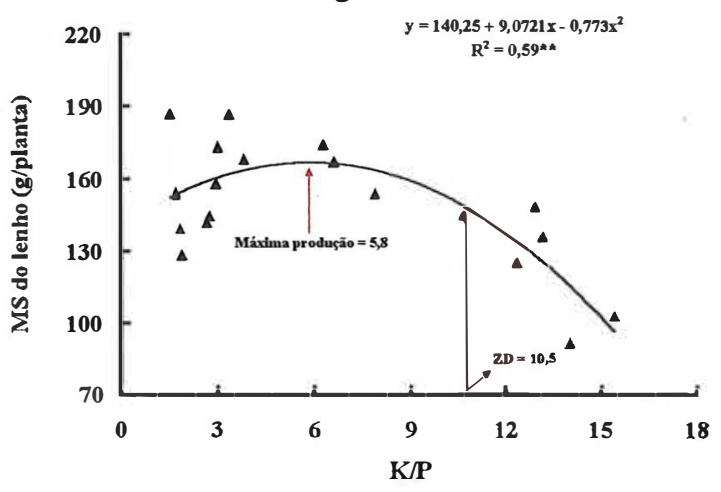

Figura 19. Produção de matéria seca lenhosa das progênies de Eucalyptus grandis em função da razão K/P nas folhas diagnóstico.

As progênies apresentaram comportamentos diferenciados para a produção de lenho conforme variou-se a razão $\mathrm{K} / \mathrm{Ca}$ nas folhas diagnóstico (Figura 20). Não houve efeito da razão K/Ca sobre a produção de lenho na progênie 1. A progênie 3 foi a que apresentou maior incremento na produção com o aumento da razão K/Ca nas folhas. Neste genótipo, o nível crítico foi de $0,9 \mathrm{~K} / 1,0 \mathrm{Ca}$, maior que o encontrado na progênie 2 . A máxima produção foi alcançada quando as plantas das progênies 2, 3 e 4 apresentaram razão foliar de $\mathrm{K} / \mathrm{Ca}$ nas folhas de 1,4, 1,6 e 1,3, respectivamente. Esses valores estão 
dentro da faixa considerada adequada $(1,3$ a $1,8 \mathrm{~K} / 1 \mathrm{Ca})$ para $E$. grandis por Silveira et al. (1999). Os mesmos autores verificaram redução na produtividade quando as relações foliares de $\mathrm{K} / \mathrm{Ca}$ eram menores que 1,0.
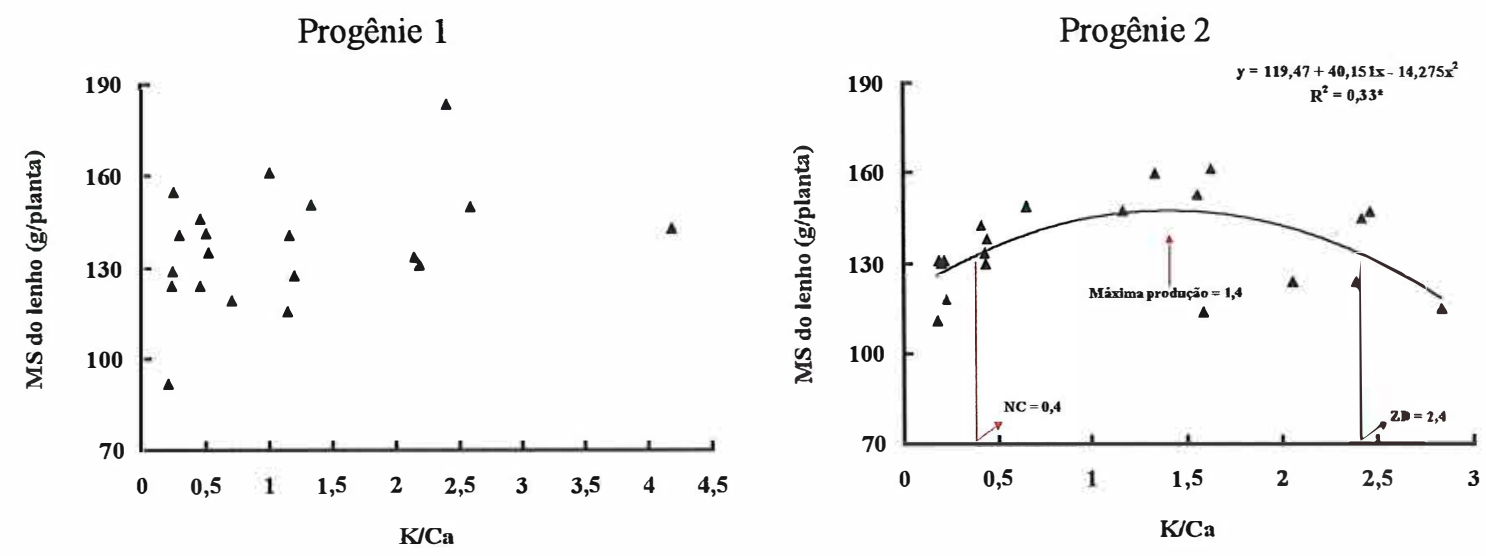

Progênie 3
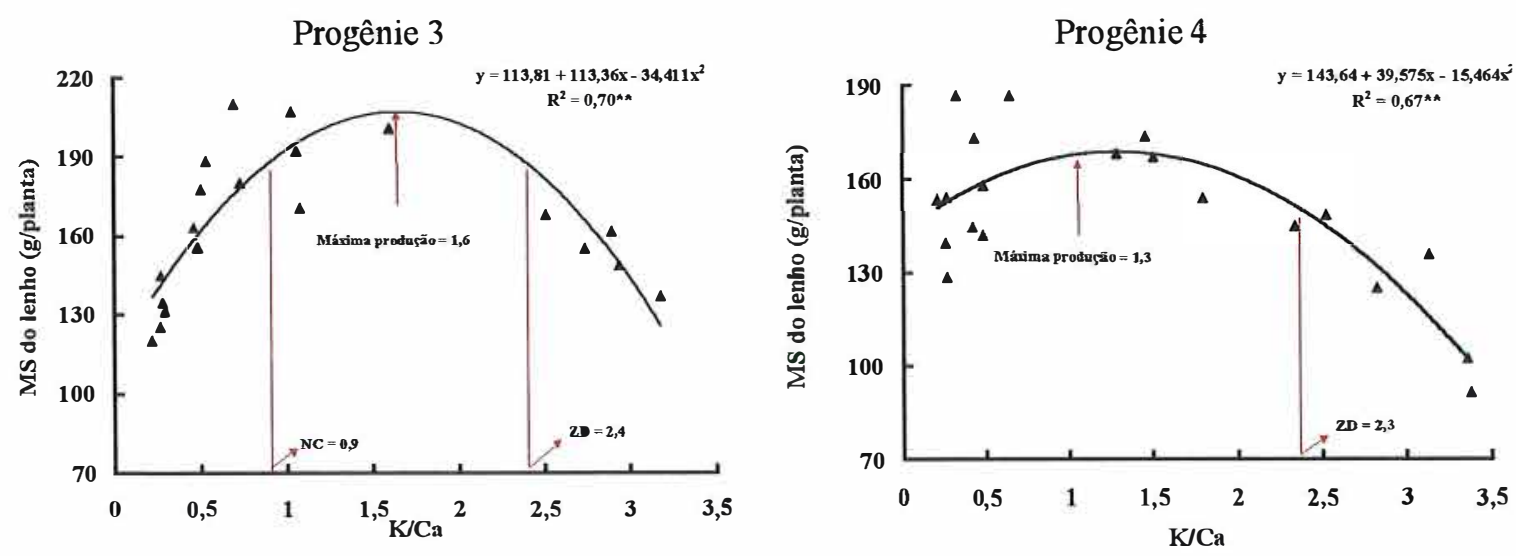

Figura 20. Produção de matéria seca lenhosa das progênies de Eucalyptus grandisem função da razão $\mathrm{K} / \mathrm{Ca}$ nas folhas diagnóstico.

Não houve relação entre a razão foliar $\mathrm{K} / \mathrm{Mg}$ e a matéria seca lenhosa na progênie 1 (Figura 21). As relações $\mathrm{K} / \mathrm{Mg}$ de 2,2 e 2,4 estavam associadas as máximas produções de lenho para as progênies 2 e 3, respectivamente. O nível crítico encontrado foi de 0,8 para a progênie 2 e 1,2 para a progênie 3 . A produção de lenho da progênie 4 
mostrou-se estável quando as relações $\mathrm{K} / \mathrm{Mg}$ variaram de 0,5 a 4,0. Para valores acima ocorreram quedas acentuadas da MS lenhosa.
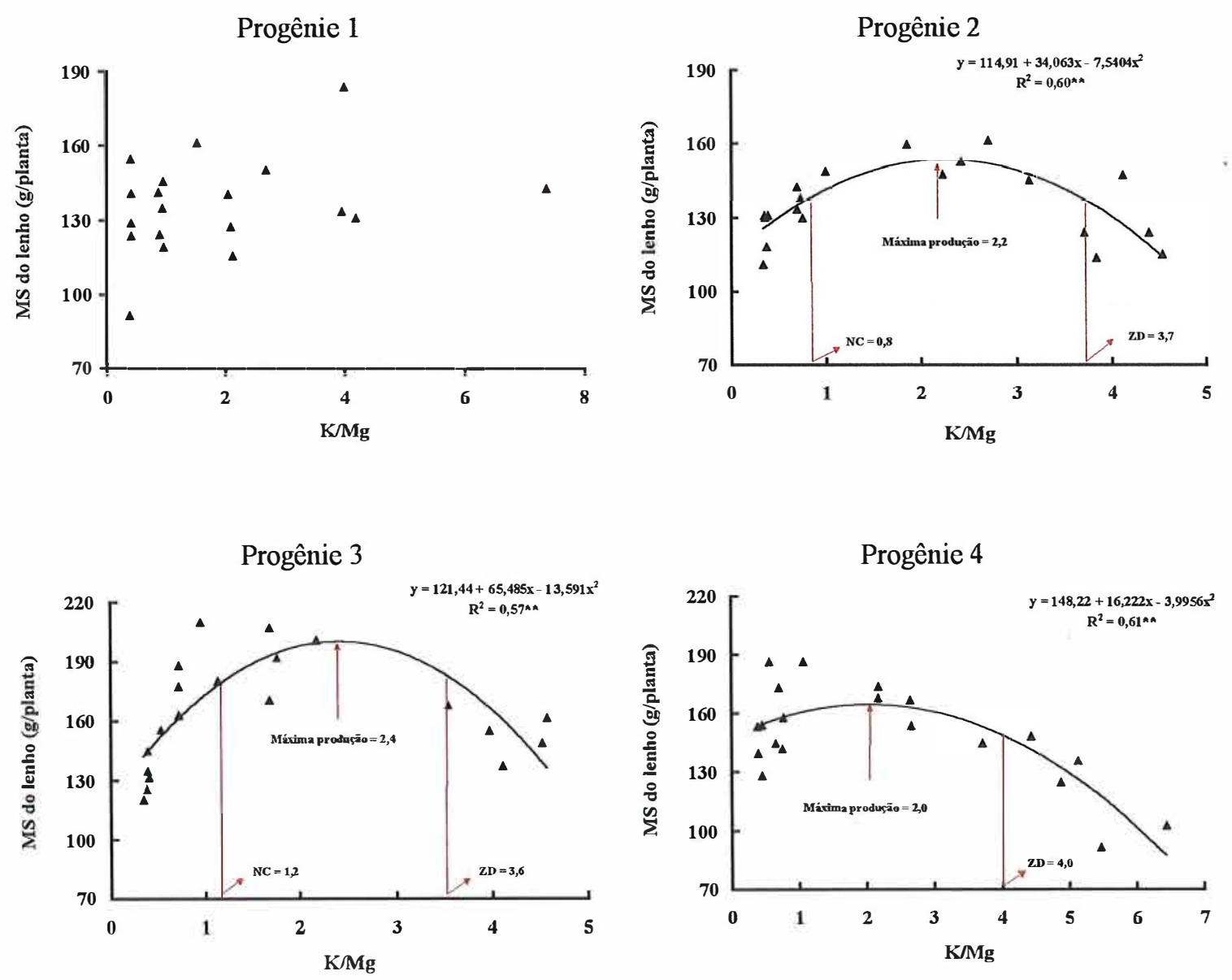

Figura 21. Produção de matéria seca lenhosa das progênies de Eucalyptus grandis em função da razão $\mathrm{K} / \mathrm{Mg}$ nas folhas diagnósticos.

Não houve relação significativa na progênie 1 entre a razão $\mathrm{K} / \mathrm{Ca}+\mathrm{Mg}$ nas folhas e a produção de lenho (Figura 22). A relação $\mathrm{K} / \mathrm{Ca}+\mathrm{Mg}$ de 0,8 proporcionou a máxima produção de lenho para as progênies 2 e 4, enquanto que para a progênie 3 , o valor foi de 1,0 . Verificou-se que $90 \%$ da produção máxima foi alcançada quando as 
plantas apresentavam a razão $\mathrm{K} / \mathrm{Ca}+\mathrm{Mg}$ nas folhas de 0,3 e 0,5 no caso das progênies 2 e 3 , respectivamente. A produção de lenho diminuiu nas progênies 2, 3 e 4 quando a razão foliar ultrapassou o valor de 1,4.

Progênie 1

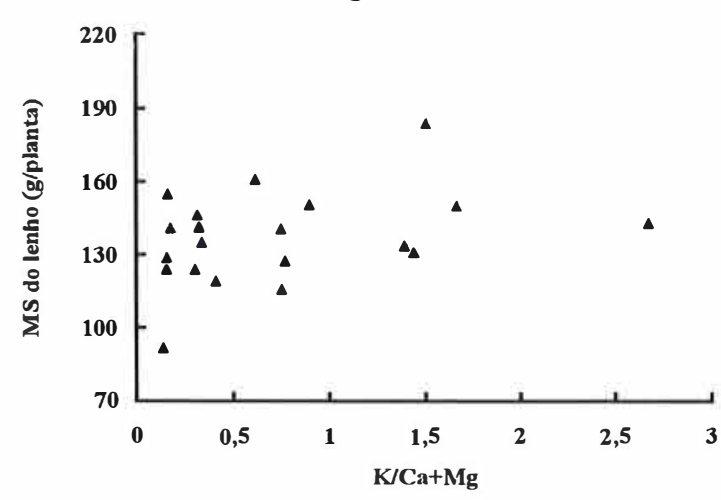

Progênie 3

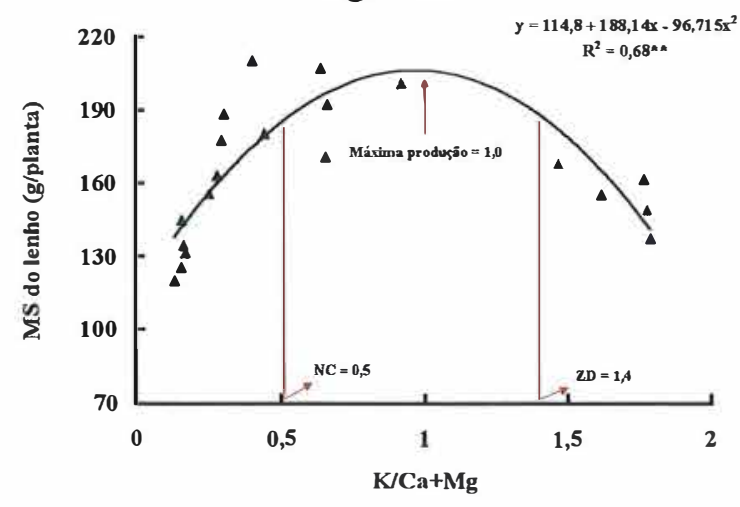

Progênie 2

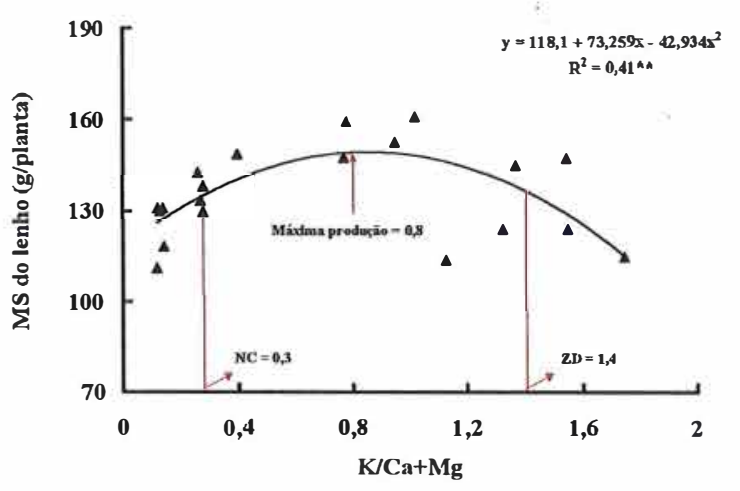

Progênie 4

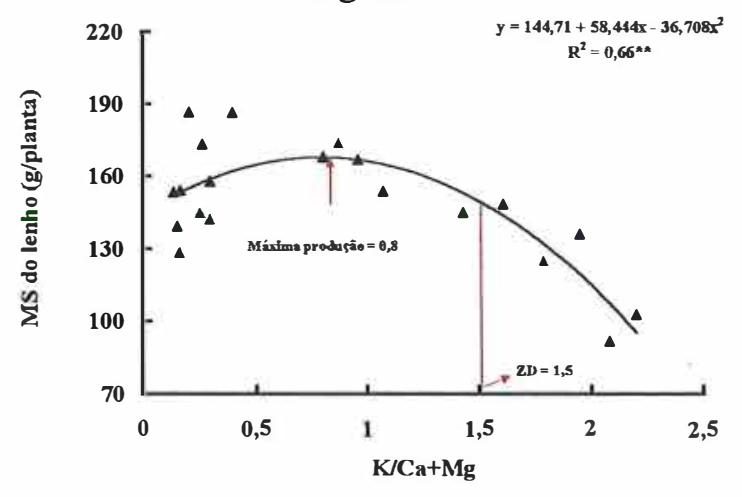

Figura 22. Produção de matéria seca lenhosa das progênies de Eucalyptus grandis em função da razão $\mathrm{K} / \mathrm{Ca}+\mathrm{Mg}$ nas folhas diagnóstico. 


\subsection{Acúmulo dos nutrientes nas progênies de Eucalyptus grandis}

\subsubsection{Acúmulo dos macronutrientes em função das progênies}

Na Tabela 30 são apresentados os conteúdos de N, P e S nas várias partes das plantas. As maiores quantidades de nitrogênio e enxofre estavam alocadas nas folhas, variando de 80,2 a $83,6 \%$ do $\mathrm{N}$ total e 64,4 a $69,5 \%$ do $\mathrm{S}$ total, conforme a progênie analisada. Não foram detectadas diferenças entre os genótipos para o conteúdo de $\mathrm{N}$ e $\mathrm{S}$ nas folhas, ramos e total. Entretanto, na casca e no lenho, o conteúdo de $\mathrm{N}$ refletiu o acúmulo de biomassa, sendo que a maior quantidade foi observada na progênie 3 quando comparada as demais. Os materiais genético apresentaram comportamentos diferenciados em relação ao acúmulo de fósforo. Para as folhas, a progênie 4 apresentou maior quantidade de $\mathrm{P}$ quando confrontada com a progênie 3. As plantas das progênies 1 e 2 apresentaram maiores conteúdos de $\mathrm{P}$ nos ramos em relação as outras duas. A única diferença para a quantidade de $\mathrm{P}$ alocada na casca ocorreu entre as progênies 1 e 2 , sendo esta maior na primeira. $\mathrm{O}$ maior conteúdo de $\mathrm{P}$ no lenho foi encontrado na progênie 3, sendo este, reflexo da maior produção de lenho deste material genético. As progênies 1 e 2 apresentaram menor quantidade de $\mathrm{S}$ na casca quando comparadas as progênies 3 e 4 . Em relação ao lenho, a progênie 3 acumulou maior quantidade de $\mathrm{S}$ que a progênie 4 .

A maior quantidade imobilizada de $\mathrm{K}$ e $\mathrm{Mg}$ foi encontrada nas folhas, cerca de 58,9 a $67,1 \%$ do $\mathrm{K}$ total e 49,9 a $54,3 \%$ do $\mathrm{Mg}$ total conforme o material genético analisado (Tabela 31). O cálcio foi uma exceção, uma vez que a quantidade nas folhas foi em média $33,7 \%$ do $\mathrm{Ca}$ total, e na casca, $34,9 \%$ do $\mathrm{Ca}$ total, diferindo dos demais macronutrientes, onde a maior quantidade estava presente nas folhas. A explicação seria que apesar da produção de casca ser inferior em $55 \%$ a de folhas, a concentração de Ca na casca $\left(21,3 \mathrm{~g} \mathrm{~kg}^{-1}\right.$ na média) chegou a ser o dobro da encontrada nas folhas $(9,5 \mathrm{~g} \mathrm{~kg}$ ${ }^{1}$ na média).

A progênie 4 apresentou maior quantidade de $\mathrm{K}$ nas folhas em relação as progênies 1 e 3 (Tabela 31). Para os ramos, o resultados obtidos foram opostos, sendo 
que o maior conteúdo de $\mathrm{K}$ ocorreu na progênie 1 quando confrontada com as progênies 3 e 4 . A progênie 3 foi a que apresentou maior quantidade de potássio na casca e no lenho. Em relação ao cálcio, houve diferença entre os materiais genéticos apenas para a quantidade nos ramos e na casca. Na casca, os maiores conteúdos foram encontrados nas progênies 1 e 3 , enquanto que nos ramos, a progênie que menos acumulou $\mathrm{Ca}$ foi a progênie 3. Para a quantidade de $\mathrm{Mg}$ alocada nas várias partes da planta, constatou-se efeito dos materiais genéticos para a casca e o lenho, sendo que em ambos os órgãos, a maior quantidade foi encontrada na progênie 3 .

O maior acúmulo de macronutrientes nas folhas é contraditório aos resultados obtidos, em condições de campo, para $E$ grandis com 7 anos (Bellote, 1979), E. fastigata e E. nitens (Madgwick et al., 1981), E. regnans com 17 anos de idade (Frederick et al., 1985), E. citriodora e E. saligna com 9 anos (Pereira et al.,1984), E. grandis com 6 anos (Reis et al., 1987) e E. grandis com 8 anos (Morais et al., 1990). Em idades mais avançadas, cerca de 70 a $90 \%$ da quantidade total dos nutrientes estava presente no caule (lenho + casca). A diferença entre tais resultados ocorre, porque na fase juvenil (1 ano), a participação da matéria seca de folhas na biomassa total é de $30 \%$, enquanto que em povoamentos adultos, varia na média de 2,5\% para E. regnans com 17 anos de idade a $8,5 \%$ para $E$. saligna (Pereira et al., 1984). Além é claro, das folhas serem os órgãos com maior concentração de macronutrientes, exceto o cálcio.

As diferenças genéticas em relação ao acúmulo de nutrientes nas diferentes partes da planta, também foram verificadas por Pereira et al. (1984) ao comparar E. saligna com E. citriodora. Os resultados mostraram que o E. citriodora acumulou mais nutriente que o E. saligna, sendo mais exigente. No entanto, no caso de progênies de Eucalyptus, os estudos são raros. 
Tabela 30. Conteúdo de nitrogênio, fósforo e enxofre nas partes das plantas das progênies de Eucalyptus grandis.

\begin{tabular}{|c|c|c|c|c|c|}
\hline Material genético & Folhas & Ramos & Casca & Lenho & Total \\
\hline & \multicolumn{5}{|c|}{$\mathrm{N}$ (mg/planta) } \\
\hline Progênie 1 & 2618 a $(80,2)$ & 287 a $(8,8)$ & 194 a $(5,9)$ & $168 \mathrm{~b}(5,1)$ & $3267 a$ \\
\hline Progênie 2 & $2840 \mathrm{a}(82,5)$ & 261 a $(7,6)$ & $179 \mathrm{ab}(5,2)$ & 162 b $(4,7)$ & 3442 a \\
\hline Progênie 3 & 2689 a $(80,3)$ & 253 a $(7,6)$ & $193 \mathrm{a}(5,8)$ & 211 a $(6,3)$ & $3346 a$ \\
\hline Progênie 4 & 3008 a $(83,6)$ & 269 a $(7,5)$ & $160 \mathrm{~b}(4,4)$ & $163 \mathrm{~b}(4,5)$ & $3600 \mathrm{a}$ \\
\hline \multirow[t]{2}{*}{ Média } & $2789(81,7)$ & $267(7,8)$ & $181(5,3)$ & $176(5,2)$ & 3413 \\
\hline & \multicolumn{5}{|c|}{$\mathrm{P}$ (mg/planta) } \\
\hline Progênie 1 & 205 ab $(38,0)$ & 110 a $(20,4)$ & 148 a $(27,4)$ & $77 \mathrm{~b}(14,2)$ & $540 a$ \\
\hline Progênie 2 & $209 \mathrm{ab}(39,3)$ & 117 a $(22,1)$ & 127 b $(23,9)$ & 78 b $(14,7)$ & 531 a \\
\hline Progênie 3 & $189 \mathrm{~b}(37,5)$ & 83 b $(16,5)$ & $139 \mathrm{ab}(27,6)$ & $93 \mathrm{a}(18,4)$ & $504 \mathrm{a}$ \\
\hline Progênie 4 & 229 a $(43,4)$ & $84 \mathrm{~b}(15,9)$ & $137 \mathrm{ab}(25,9)$ & $78 \mathrm{~b}(14,8)$ & $528 \mathrm{a}$ \\
\hline \multirow[t]{2}{*}{ Média } & $208(39,6)$ & $98(18,7)$ & $138(26,3)$ & $81(15,4)$ & 525 \\
\hline & \multicolumn{5}{|c|}{$\mathrm{S}$ (mg/planta) } \\
\hline Progênie 1 & 307 a $(68,4)$ & 48 a $(10,7)$ & $50 \mathrm{~b}(11,1)$ & 44 ab $(9,8)$ & 449 a \\
\hline Progênie 2 & 297 a $(69,2)$ & 45 a $(10,5)$ & $45 \mathrm{~b}(10,5)$ & 42 ab $(9,8)$ & $429 a$ \\
\hline Progênie 3 & 286 a $(64,4)$ & 53 a $(11,9)$ & 55 a $(12,4)$ & 50 a $(11,3)$ & $444 a$ \\
\hline Progênie 4 & 353 a $(69,5)$ & 59 a $(11,6)$ & 50 a $(9,8)$ & $46 \mathrm{~b}(9,1)$ & $508 \mathrm{a}$ \\
\hline Média & $311(68,1)$ & $51(11,1)$ & $50(10,9)$ & $45(9,9)$ & 457 \\
\hline
\end{tabular}

Médias seguidas de mesma letra não diferem entre si pelo teste de Tukey ao nível de $5 \%$ de probabilidade. Os valores entre parênteses são percentuais em relação ao conteuido total.

Tabela 31. Conteúdo de potássio, cálcio, magnésio nas partes das plantas das progênies de Eucalyptus grandis.

\begin{tabular}{|c|c|c|c|c|c|}
\hline Material genético & Folhas & Ramos & Casca & Lenho & Total \\
\hline & \multicolumn{5}{|c|}{$\mathrm{K}$ (mg/planta) } \\
\hline Progênie 1 & $1099 \mathrm{c}(58,9)$ & 216 a $(11,6)$ & $149 \mathrm{~b}(8,0)$ & $401 \mathrm{ab}(21,5)$ & $1865 \mathrm{a}$ \\
\hline Progênie 2 & $1315 \mathrm{ab}(64,6)$ & $209 \mathrm{ab}(10,2)$ & $152 \mathrm{~b}(7,5)$ & $360 \mathrm{bc}(17,7)$ & 2036 a \\
\hline Progênie 3 & 1157 bc $(59,4)$ & 193 b $(9,9)$ & 173 a $(8,9)$ & 424 a $(21,8)$ & 1947 a \\
\hline Progênie 4 & 1349 a $(67,1)$ & $186 \mathrm{~b}(9,3)$ & $139 \mathrm{~b}(6,9)$ & $336 \mathrm{c}(16,7)$ & 2010 a \\
\hline \multirow[t]{2}{*}{ Média } & $1230(62,6)$ & $201(10,2)$ & $153(7,8)$ & $380(19,4)$ & 1964 \\
\hline & \multicolumn{5}{|c|}{$\mathrm{Ca}$ (mg/planta) } \\
\hline Progênie 1 & 1413 a $(32,4)$ & 1116 a $(25,6)$ & 1555 a $(35,6)$ & 282 a $(6,4)$ & 4366 a \\
\hline Progênie 2 & 1449 a $(36,1)$ & 996 ab $(24,8)$ & $1331 \mathrm{ab}(33,1)$ & 242 a $(6,0)$ & 4018 a \\
\hline Progênie 3 & 1155 a $(30,2)$ & $900 \mathrm{~b}(23,5)$ & 1498 a $(39,2)$ & 270 a $(7,1)$ & 3823 a \\
\hline Progênie 4 & 1418 a $(36,1)$ & $1012 \mathrm{ab}(25,8)$ & $1250 \mathrm{~b}(31,9)$ & 243 a $(6,2)$ & 3923 a \\
\hline \multirow[t]{2}{*}{ Média } & $1359(33,7)$ & $1006(25,0)$ & $1408(34,9)$ & $259(6,4)$ & 4032 \\
\hline & \multicolumn{5}{|c|}{$\mathrm{Mg}$ (mg/planta) } \\
\hline Progênie 1 & 726 a $(54,3)$ & 342 a $(25,6)$ & 166 b $(12,4)$ & $103 \mathrm{ab}(7,7)$ & 1337 a \\
\hline Progênie 2 & 785 a $(54,3)$ & 407 a $(28,2)$ & $163 \mathrm{~b}(11,3)$ & $90 \mathrm{ab}(6,2)$ & 1445 a \\
\hline Progênie 3 & 732 a $(52,4)$ & 344 a $(24,6)$ & 215 a $(15,4)$ & 107 a $(7,6)$ & 1398 a \\
\hline Progênie 4 & 787 a $(49,9)$ & 496 a $(31.5)$ & 208 a $(13,2)$ & 86 b $(5,4)$ & 1577 a \\
\hline Média & $757(52,6)$ & $397(27,6)$ & $188(13,1)$ & $96(6,7)$ & 1438 \\
\hline
\end{tabular}

Médias seguidas de mesma lára não diferem entre si pelo teste de Tukey ao nível de probabilidade. Os valores entre parènteses são percentuais em relação ao conteudo total. 


\subsubsection{Acúmulo dos macronutrientes em função das doses de potássio}

Os conteúdos de potássio nas várias partes da planta em função da dose de potássio na solução nutritiva são apresentados na Figura 23. Em função da queda acentuada de produção de matéria seca na dose mais alta de potássio na solução conforme já discutido anteriormente, ocorreram incrementos decrescentes no conteúdo de $\mathrm{K}$ entre a dose de 175,5 e $526,5 \mathrm{mg} \mathrm{L}^{-1}$. Em todas as doses de potássio, o conteúdo de potássio nas progênies obedeceu a seguinte ordem: folhas $>$ lenho $>$ ramos $>$ casca.
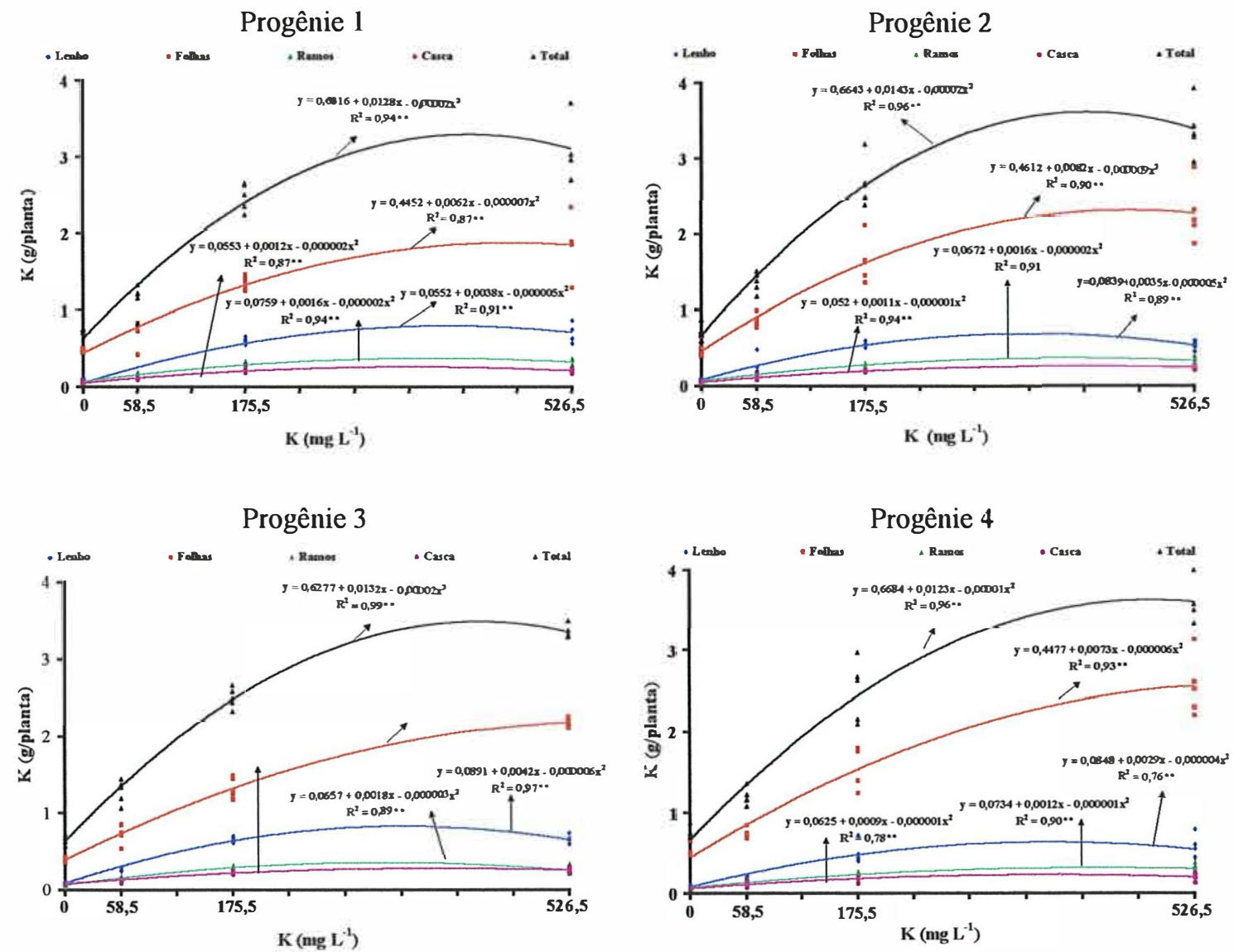

Figura 23. Quantidade acumulada de K nas folhas, ramos, casca, lenho e total das progênies de Eucalyptus grandis em função das doses de potássio na solução nutritiva. 
O conteúdo total dos macronutrientes variou em função das doses utilizadas de potássio na solução nutritiva (Figura 24). O conteúdo de fósforo não apresentou variações significativas com o aumento da dose de $\mathrm{K}$. De maneira geral, os conteúdos dos macronutrientes decresceram com o aumento do fornecimento de potássio as plantas, com exceção do K.

$\mathrm{Na}$ ausência de $\mathrm{K}$, a quantidade total desse macronutriente foi praticamente igual a de enxofre. Verifica-se ainda que o conteúdo total de potássio nas progênies 2, 3 e 4 foi maior que o de cálcio e o de nitrogênio somente na dose mais elevada de potássio. A quantidade total acumulada de $\mathrm{Mg}$ foi superior a de potássio quando as plantas foram cultivadas tanto na ausência como na dose de $58,5 \mathrm{mg} \mathrm{L}^{-1}$, principalmente na primeira situação. Independentemente da progênie, as extrações totais dos macronutrientes foram a seguinte: a) na ausência de $\mathrm{K}: \mathrm{Ca}>\mathrm{N}>\mathrm{Mg}>\mathrm{K} \geq \mathrm{S}$; b) na dose de 58,5 $\mathrm{mg} \mathrm{L}^{-1}: \mathrm{Ca}>\mathrm{N}>\mathrm{Mg}>\mathrm{K}>\mathrm{S}$; $\mathrm{c}$ ) na dose de 175,5 $\mathrm{mg} \mathrm{L}^{-1}: \mathrm{Ca}>\mathrm{N}>\mathrm{K}>>$ $\mathrm{Mg}>\mathrm{S}$; d) na dose de 526,5 $\mathrm{mg} \mathrm{L}^{-1}: \mathrm{K} \geq \mathrm{Ca} \geq \mathrm{N}>\mathrm{Mg}>\mathrm{S}$ (Figura 24).

Os resultados de acúmulos totais de nutrientes na dose de $175,5 \mathrm{mg} \mathrm{de} \mathrm{K} \mathrm{L}^{-1}$, estão de acordo com os encontrados por Morais et al. (1990) em E. grandis na região de Viçosa/MG e Paraopeba/MG e por Bellote (1979) em E. grandis na região de Mogi Guaçu/SP. Em ambos os estudos, o potássio foi o terceiro nutriente em quantidade extraída, ficando abaixo somente do nitrogênio e do cálcio. 
Progênie 1

Progênie 2
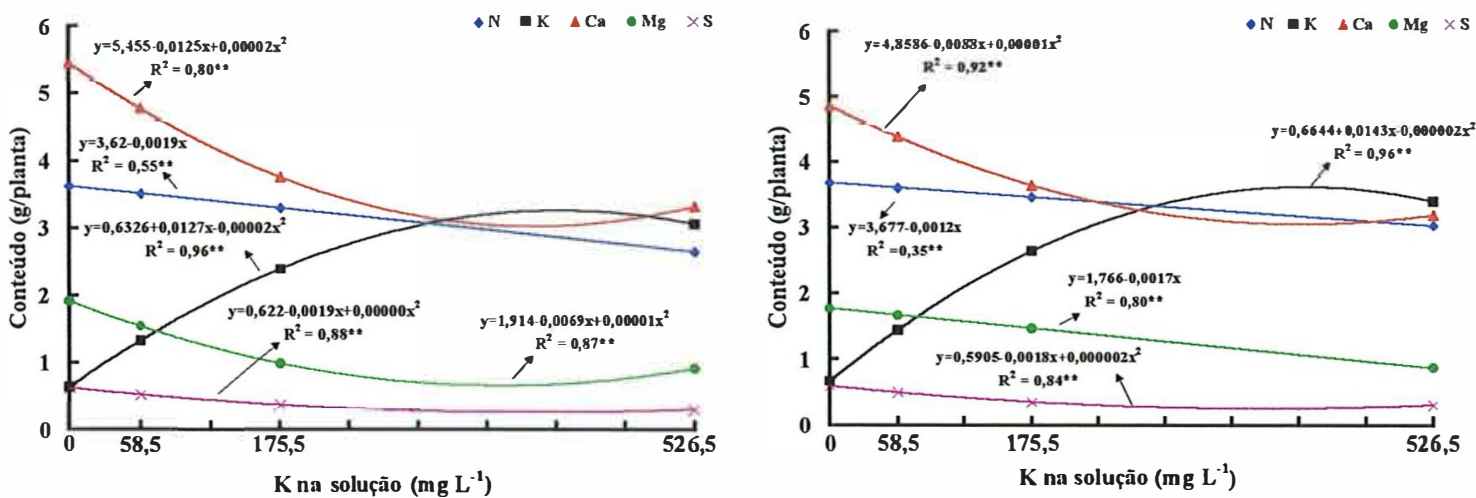

Progênie 3

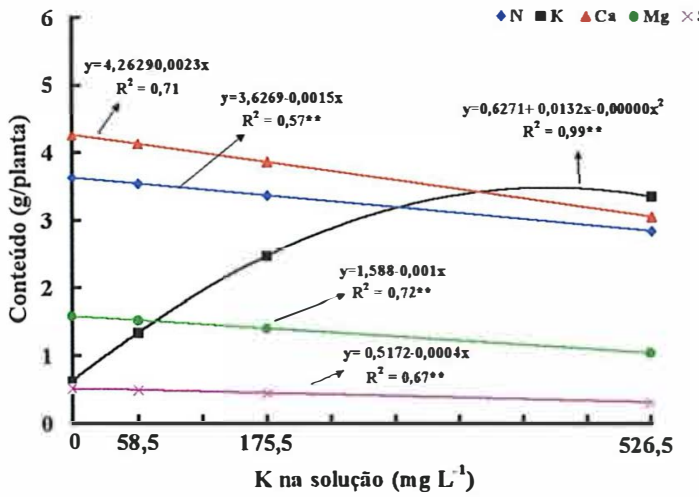

Progênie 4

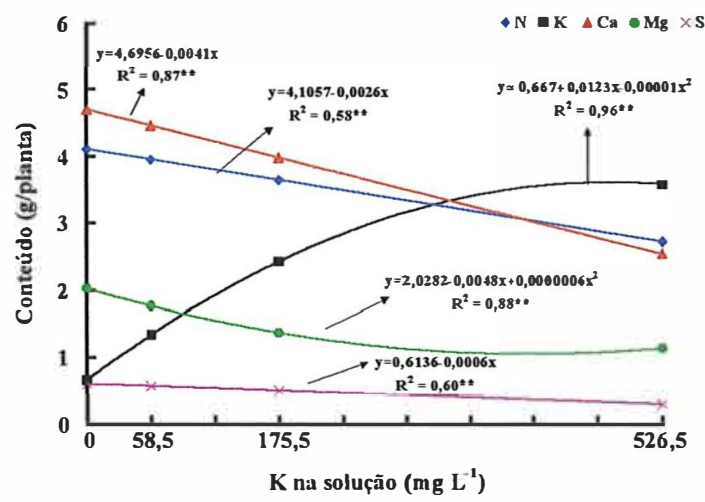

Figura 24. Quantidade total acumulada de N, K, Ca, Mg e S nas progênies de Eucalyptus grandis em função das doses de potássio na solução nutritiva.

\subsubsection{Acúmulo dos micronutrientes em função das progênies}

O manganês foi o micronutriente com maior contéudo total quando comparado aos demais, sendo na média cerca de 6,5 vezes mais acumulado que o ferro (Tabela 32). De maneira geral, a ordem no conteúdo total foi: $\mathrm{Mn}>\mathrm{Fe}>\mathrm{Zn}=\mathrm{B}>\mathrm{Cu}$. A maior quantidade de B, Fe, Mn e $\mathrm{Zn}$ estava presente nas folhas, principalmente para o Mn, cerca de $80 \%$ do conteúdo total. O cobre respondeu de forma diferenciada ao acúmulo de nutriente, uma vez que as suas quantidades nas partes da planta apareceram 
em proporções mais equilibradas quando comparado aos outros micronutrientes $(25,9 \%$ nas folhas, $16,8 \%$ nos ramos, $28,4 \%$ na casca e $28,9 \%$ no lenho).

Um dos poucos trabalhos realizados sobre a extração de micronutrientes por Eucalyptus foi desenvolvido por Bellote (1979), que encontrou elevada quantidade total de Mn, sendo esta cerca de 3,5 vezes maior que a de ferro. A ordem do conteúdo total dos micronutrientes foi: $\mathrm{Mn}>\mathrm{Fe}>\mathrm{B}>\mathrm{Cu}>\mathrm{Zn}$.

A diferença marcante em relação aos dados do presente estudo é que no caso de Bellote (1979), a quantidade de $\mathrm{Zn}$ acumulada foi a menor entre os micronutrientes. Provavelmente, a floresta amostrada por Bellotte (1979) poderia estar com concentrações deficientes de $\mathrm{Zn}$ nos tecidos vegetais.

Entre as progênies estudadas, não foi constatada diferença significativa para: a) conteúdo de $\mathrm{Cu}$ nas folhas, na casca, no lenho e total; b) conteúdo de Fe na casca e no lenho; c) conteúdo de Mn nas folhas, na casca, no lenho e total; d) conteúdo de zinco nas folhas, ramos, casca e total. Em relação ao boro, a progênie 1 apresentou maior quantidade total quando comparada com a progênie 3. As maiores quantidades de B nas folhas ocorreram nas plantas das progênies 2 e 4 , enquanto que para os ramos, o maior conteúdo foi observado na progênie 1. Ao comparar as progênies, verificou-se também que as menores quantidades de $\mathrm{B}$ na casca ocorriam nas plantas da progênie 1. A única diferença entre os materiais genéticos para a quantidade de cobre ocorreu nos ramos, sendo que a progênie 4 acumulou mais em relação a progênie 2 . Por outro lado, o conteúdo de ferro nas folhas foi menor na progênie 3 quando comparada as progênies 2 e 4, enquanto que para os ramos, as diferenças foram entre a progênie 2 e as progênies 3 e 4, com maior conteúdo na primeira. A progênie 1 apresentou maior conteúdo de $\mathrm{Mn}$ nos ramos em relação a progênie 3 . O efeito dos materiais genéticos sobre o conteúdo de zinco foram verificados quando a parte da planta analisada era o lenho, com maior quantidade na progênie 3 em relação a progênie 2 . 
Tabela 32. Conteúdo de boro, cobre, ferro, manganês e zinco nas partes das plantas das progênies de Eucalyptus grandis.

\begin{tabular}{|c|c|c|c|c|c|}
\hline Material genético & Folhas & Ramos & Casca & Lenho & Total \\
\hline & \multicolumn{5}{|c|}{$\mathrm{B}$ (mg/planta) } \\
\hline Progênie 1 & $4,10 \mathrm{ab}(49,9)^{2}$ & $1,29 \mathrm{a}(15,7)$ & 1,53 a $(18,6)$ & $1,30 \mathrm{ab}(15,8)$ & $8,22 \mathrm{a}$ \\
\hline Progênie 2 & 4,54 a $(58,4)$ & $1,00 \mathrm{~b}(12,9)$ & $1,10 \mathrm{c}(14,1)$ & $1,14 \mathrm{~b}(14,6)$ & $7,78 \mathrm{ab}$ \\
\hline Progênie 3 & $3,75 \mathrm{~b}(51,5)$ & $0,71 \mathrm{c}(9,8)$ & $1,37 \mathrm{ab}(18,8)$ & 1,45 a $(19,9)$ & $7,28 \mathrm{~b}$ \\
\hline Progênie 4 & 4,53 a $(58,3)$ & $0,73 \mathrm{c}(9,4)$ & $1,29 \mathrm{bc}(16,6)$ & $1,22 \mathrm{ab}(15,7)$ & $7,77 \mathrm{ab}$ \\
\hline \multirow[t]{2}{*}{ Média } & $4.23(54,5)$ & $0,93(12,0)$ & $1,32(17,0)$ & $1,28(16,5)$ & 7.76 \\
\hline & \multicolumn{5}{|c|}{$\mathrm{Cu}$ (mg/planta) } \\
\hline Progênie 1 & $1,00 \mathrm{a}(26,5)$ & 0,65 ab $(17,2)$ & 0,95 a $(25,2)$ & 1,17 a $(31,1)$ & $3,77 \mathrm{a}$ \\
\hline Progênie 2 & 0,91 a $(27,1)$ & $0,45 \mathrm{~b}(13,4)$ & $1,05 \mathrm{a}(31,2)$ & $0,95 \mathrm{a}(28,3)$ & $3,36 \mathrm{a}$ \\
\hline Progênie 3 & 0,81 a $(22,5)$ & 0,61 ab $(16,9)$ & 1,12 a $(31,1)$ & 1,06 a $(29,5)$ & $3,60 \mathrm{a}$ \\
\hline Progênie 4 & $1,04 \mathrm{a}(27,4)$ & $0,72 \mathrm{a}(19,0)$ & $1,01 \mathrm{a}(26,6)$ & $1,02 \mathrm{a}(26,9)$ & $3,79 \mathrm{a}$ \\
\hline \multirow[t]{2}{*}{ Média } & $0.94(25,9)$ & $0,61(16,8)$ & $1,03(28,4)$ & $1,05(28,9)$ & 3,63 \\
\hline & \multicolumn{5}{|c|}{$\mathrm{Fe}(\mathrm{mg} /$ planta $)$} \\
\hline Progênie 1 & $10,38 \mathrm{ab}(52,1)$ & $4,36 \mathrm{ab}(21,9)$ & $2,10 \mathrm{a}(10,6)$ & 3,07 a $(15,4)$ & $19,90 \mathrm{ab}$ \\
\hline Progênie 2 & 10,75 a $(49,5)$ & $6,00 \mathrm{a}(27,6)$ & 1,99 a $(9,1)$ & 3,01 a $(13,8)$ & $21,73 \mathrm{a}$ \\
\hline Progênie 3 & $8,18 \mathrm{~b}(49,1)$ & $3,35 \mathrm{~b}(20,1)$ & $2,29 \mathrm{a}(13,7)$ & 2,86 a $(17,1)$ & 16,65 b \\
\hline Progênie 4 & 11,67 a $(57,6)$ & $3,98 b(19,6)$ & 1,96 a $(9,7)$ & $2,67 \mathrm{a}(13,1)$ & $20,26 \mathrm{a}$ \\
\hline \multirow[t]{2}{*}{ Média } & $10,24(52,1)$ & $4,42(22,5)$ & $2,08(10,6)$ & $2,90(14,8)$ & 19,64 \\
\hline & \multicolumn{5}{|c|}{ Mn (mg/planta) } \\
\hline Progênie 1 & 122,74 a $(79,9)$ & 7,70 a $(5,0)$ & $9, \overline{43 \mathrm{a}(6,1)}$ & 13,84 a $(9,0)$ & 153,71 a \\
\hline Progênie 2 & 97,52 a $(79,8)$ & $6,06 \mathrm{ab}(4,9)$ & 8,75 a $(7,2)$ & 9,85 a $(8,1)$ & $122,18 \mathrm{a}$ \\
\hline Progênie 3 & $90,80 \mathrm{a}(79,1)$ & $5,51 \mathrm{~b}(4,8)$ & 8,24 a $(7,1)$ & $10,28 \mathrm{a}(9,0)$ & $114,83 \mathrm{a}$ \\
\hline Progênie 4 & $101,34 \mathrm{a}(80,5)$ & $5,86 \mathrm{ab}(4,7)$ & 8,00 a $(6,3)$ & 10,63 a $(8,5)$ & $125,83 \mathrm{a}$ \\
\hline \multirow[t]{2}{*}{ Média } & $103,10(79,8)$ & $6,28(4,9)$ & $8,60(6,6)$ & $11,15(8,6)$ & 129.13 \\
\hline & \multicolumn{5}{|c|}{ Zn (mg/planta) } \\
\hline Progênie 1 & 4,01 a $(56,4)$ & 1,54 a $(21,6)$ & 0,80 a $(11,3)$ & $0,76 \mathrm{ab}(10,7)$ & $7,11 \mathrm{a}$ \\
\hline Progênie 2 & 4,57 a $(59,2)$ & $1,56 \mathrm{a}(20,2)$ & 0,93 a $(12,0)$ & $0,66 \mathrm{~b}(8,6)$ & 7,72 a \\
\hline Progênie 3 & 4,39 a $(57,2)$ & $1,26 \mathrm{a}(16,5)$ & $1,10 \mathrm{a}(14,3)$ & $0,92 \mathrm{a}(12,0)$ & $7,67 \mathrm{a}$ \\
\hline Progênie 4 & 5,41 a $(62,1)$ & 1,45 a $(16,6)$ & 1,03 a $(11,8)$ & $0,83 a b(9,5)$ & 8,72 a \\
\hline Média & $4.60(59,0)$ & $1,45(18,6)$ & $0,96(12.3)$ & $0.79(10,1)$ & 7,80 \\
\hline
\end{tabular}

Médias seguidas de mesma letra não diferem entre si pelo teste de Tukey ao nivel de $5 \%$ de probabilidade. Valores entre parênteses são percentuais em relação ao conteúdo total.

\subsubsection{Acúmulo dos micronutrientes em função das doses de potássio}

Os efeitos das doses de $\mathrm{K}$ sobre o quantidade total acumulada de $\mathrm{Cu}, \mathrm{Mn}$ e Zn são apresentados na Figura 25. O conteúdo total de cobre teve comportamento semelhante para as progênies 1, 2 e 4, sendo que com o aumento das doses de K ocorreu quedas lineares na quantidade extraída desse micronutriente. Para a progênie 3 , os efeitos foram quadráticos refletindo o acúmulo de biomassa em função das doses de $\mathrm{K}$. Em relação ao manganês, as progênies 1 e 4 apresentaram quedas acentuadas no 
conteúdo total com o aumento do fornecimento de $\mathrm{K}$. Os efeitos das doses de $\mathrm{K}$ sobre a quantidade total de Mn para as progênies 2 e 3 foram quadráticos, sendo estes reflexos da produção de matéria seca total. $O$ conteúdo total de zinco das progênies 1,3 e 4 decresceram linearmente com o aumento do suprimento de potássio. Os efeitos das doses de $\mathrm{K}$ sobre o conteúdo total de $\mathrm{B}$ e Fe nas progênies não foram significativos.
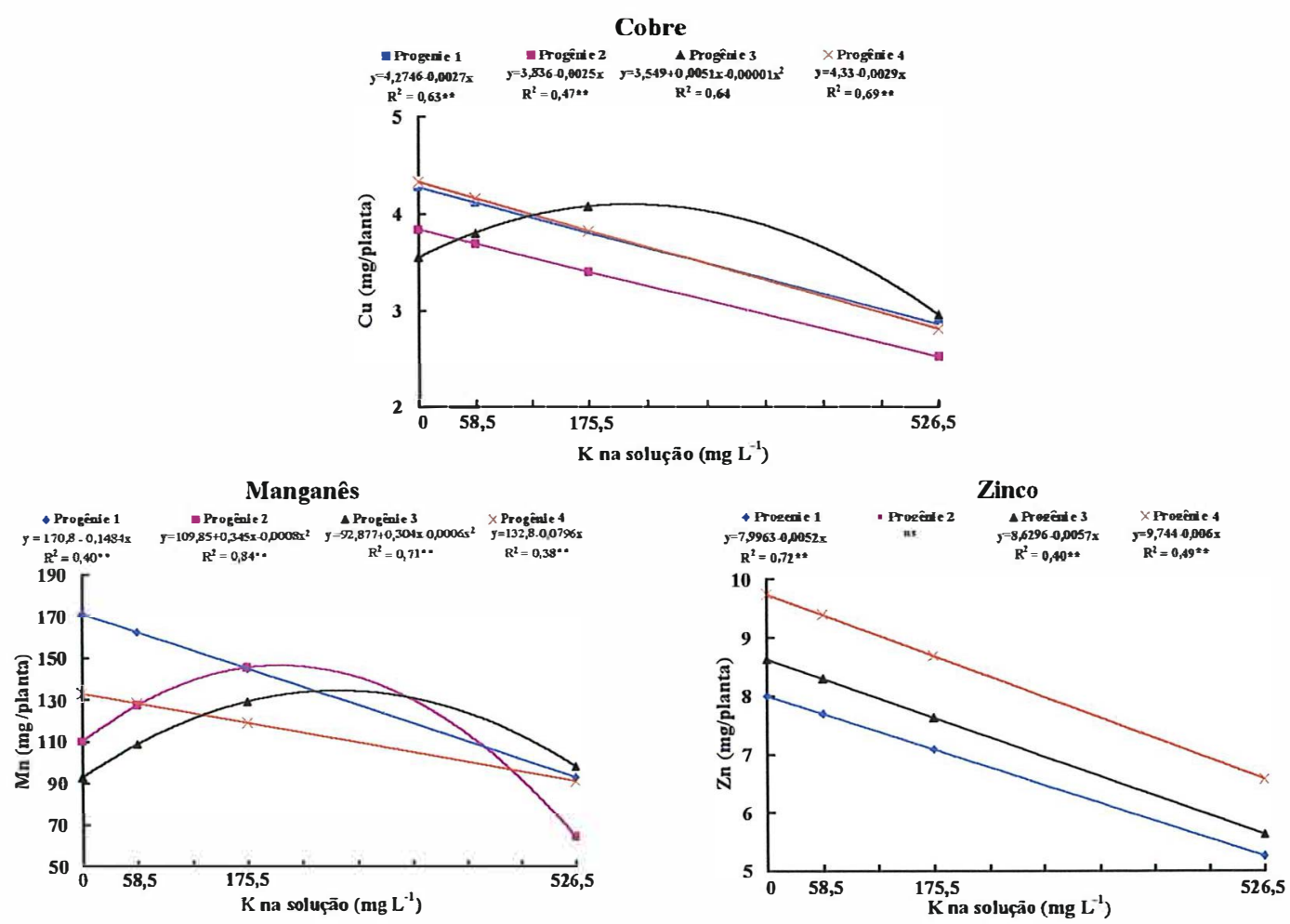

Figura 25. Quantidade total acumulada de $\mathrm{Cu}, \mathrm{Mn}$ e $\mathrm{Zn}$ das progênies de Eucalyptus grandis em função das doses de potássio na solução nutritiva. 


\subsection{Eficiência de utilização de K pelas progênies de Eucalyptus grandis}

\subsubsection{Produção de matéria seca total e lenhosa}

Para a comparação da eficiência de utilização de potássio pelas progênies foi calculado o índice EKT através das equações de regressões entre a matéria seca total ou lenhosa produzida e o conteúdo de $\mathrm{K}$ na planta (Figuras 26 e 27). O índice EKT é expresso pelo quociente entre a quantidade de matéria seca produzida e a unidade de potássio contido na planta.

A relação entre a quantidade absorvida de $\mathrm{K}$ e a produção de matéria seca lenhosa ou total não foi significativa para a progênie 1 (Figuras 26 e 27). Não ocorreram diferenças significativas entre as progênies 3 e 4, para a eficiência de utilização de $K$ tanto para a produção de matéria seca total como lenhosa (Figuras 26 e 27), embora a progênie 3 tenha sido mais responsiva à adição de potássio. As duas progênies apresentaram maior eficiência em relação a progênie 2. Ao comparar as progênies, verificou-se que para a produção de uma unidade de matéria seca total, as progênies 1 e 3 consumiam $17 \%$ e $5 \%$ a mais de potássio que a progênie 4 , respectivamente. A baixa eficiência de utilização de potássio pela progênie 2 ficou mais evidente em relação a produção de lenho. Essa progênie necessitou de 35\% a mais de K que a progênie 3 para produzir a mesma quantidade de lenho (Figura 27).

Barros et al. (1985) verificaram que não existe necessariamente uma relação direta entre a produção de biomassa e a eficiência de utilização dos nutrientes por clone de Eucalyptus. Resultados semelhantes foram encontrados entre as progênies 3 e 4, sendo que a produção de lenho foi maior na progênie 3, sem haver diferenças entre elas na eficiência de utilização de K. Souza (1994) também encontrou diferenças significativas entre 15 clones de E. grandis, na região de Quartel Geral/MG, quanto a eficiência de uso de potássio. Resultados similares foram obtidos em E. saligna e $E$. citriodora, sendo a primeira mais eficiente em $60 \%$ no uso de potássio para a produção de madeira. A eficiência de utilização de $\mathrm{K}$ em mudas (60 a 90 dias de idade) de clones de Eucalyptus é menos pronunciada que nas condições de povoamentos adultos, conforme dados obtidos por Souza et al. (1994) e Camargo (1997). Estudando quatro 
clones de Eucalyptus na fase de viveiro, Camargo (1997) verificou que não havia diferença significativa entre 3 clones, quanto a eficiência do uso de potássio. Além disso, é importante ressaltar que o crescimento da planta pode estar relacionado à eficiência de absorção ou de utilização de um ou mais nutrientes ao mesmo tempo.

Nos programas de melhoramento de Eucalyptus, quando se utiliza a eficiência nutricional como critério de seleção, é fundamental saber se: a) o genótipo eficiente no uso de determinado nutriente poderá não ser para outro, com isso a seleção deverá tomar como base o nutriente mais limitante; b) existe correlação entre a eficiência nutricional do material genético e as características de crescimento, principalmente celulose, no caso das empresas de papel.
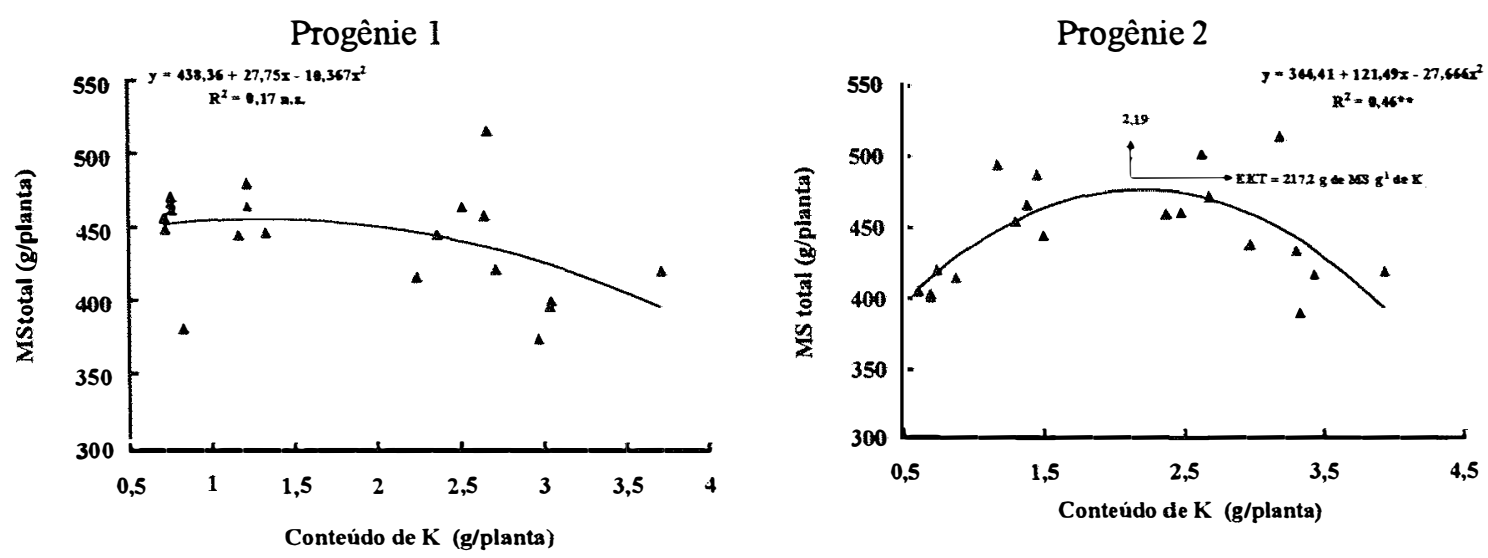

Progênie 3
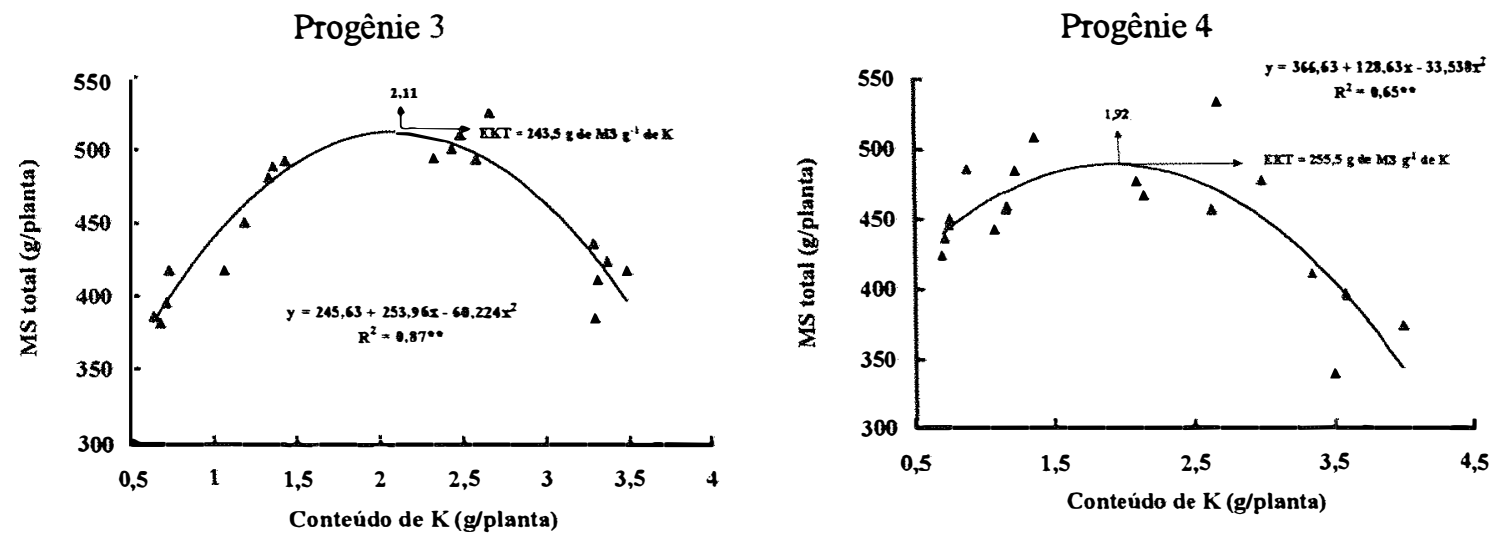

Figura 26. Relação entre a matéria seca total produzida e o conteúdo de potássio nas progênies de Eucalyptus grandis. 
Progênie 1

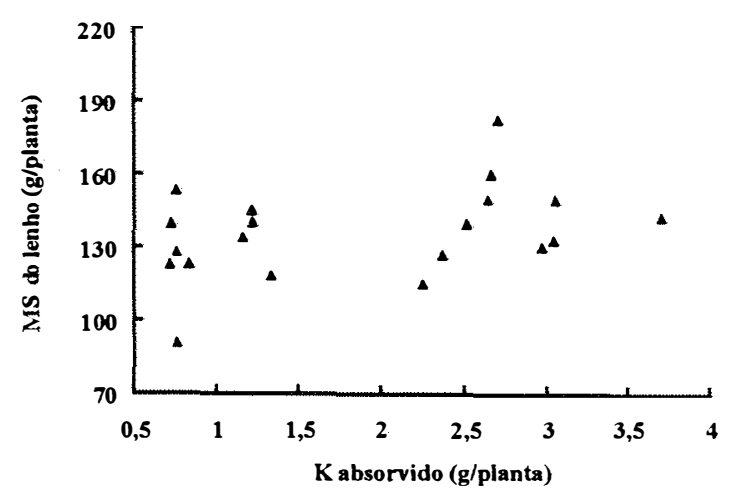

Progênie 3

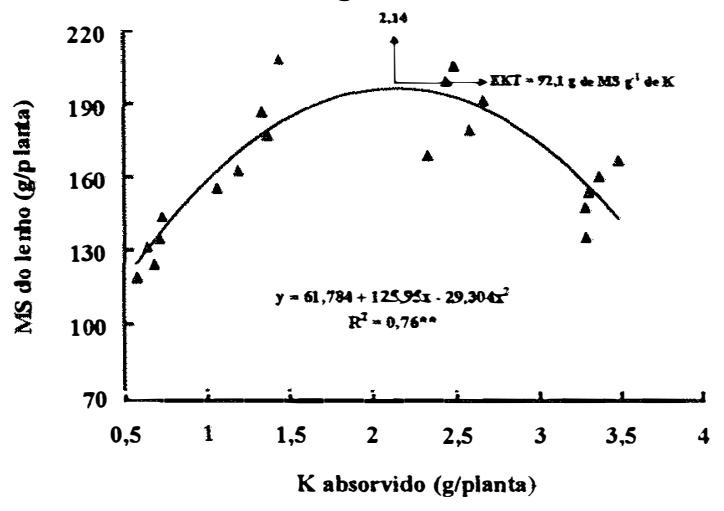

Progênie 2

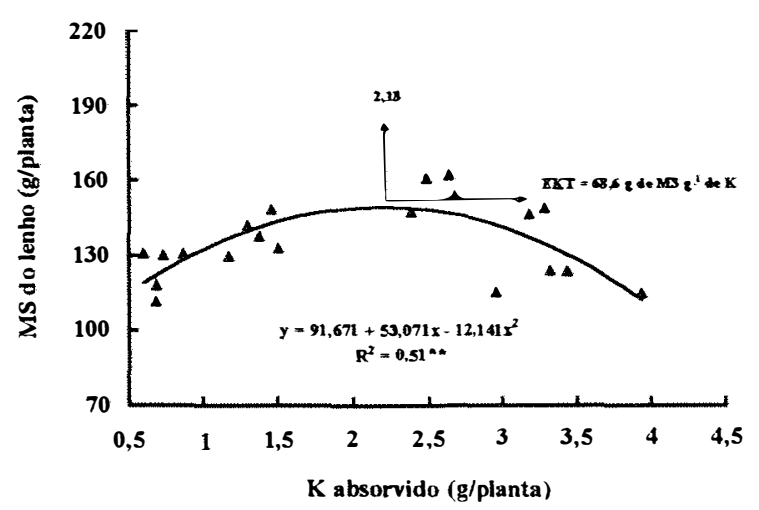

Progênie 4

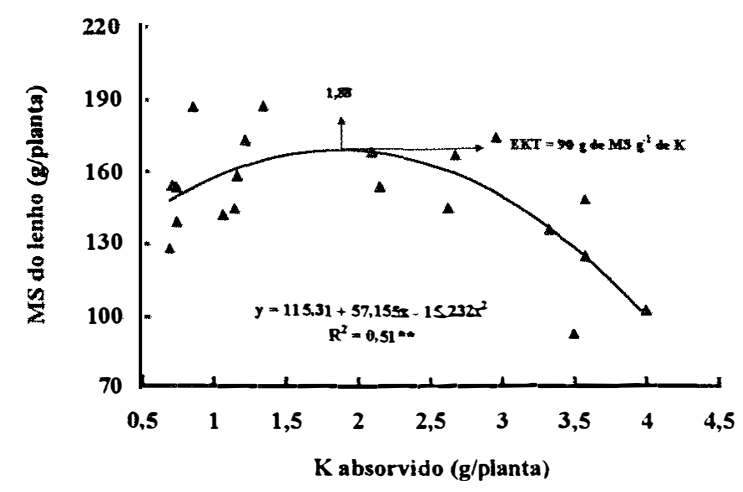

Figura 27. Relação entre a matéria lenhosa produzida e o conteúdo de potássio nas progênies de Eucalvptus grandis.

\subsubsection{Produção de holocelulose}

A maioria dos estudos sobre a eficiência de utilização dos nutrientes em Eucalyptus tem sido voltado para a produção de madeira (lenho), sem considerar que o produto principal é a celulose. Com esse objetivo, foi calculado o índice EKCT através das equações de regressões entre a quantidade de holocelulose (celulose + hemicelulose) produzida e o conteúdo de $\mathrm{K}$ na planta (Figura 28). $\mathrm{O}$ índice EKCT foi expresso pelo quociente entre a quantidade de holocelulose produzida e a unidade de potássio contido na planta. A relação entre a quantidade absorvida de $\mathrm{K}$ e a produção de holocelulose foi 
diferente entre as progênies, principalmente para a progênie 1. Apesar do baixo coeficiente de determinação, embora significativo ao nível de $5 \%$ de probabilidade, verificou-se que a produção de holocelulose aumentou linearmente com o conteúdo de potássio na planta. Este resultado ocorreu porque nessa progênie maiores concentrações de celulose no lenho foram alcançadas à medida que se aumentava o fornecimento de $\mathrm{K}$ às plantas, conforme será discutido no item 4.9.3.

A maior eficiência de uso de $K$ foi encontrada nas progênies 3 e 4 , não havendo diferença significativa entre elas. Entretanto, ao comparar as progênies, verificou-se que a progênie 2 consumia $45 \%$ a mais de potássio que a progênie 3, para produzir uma unidade de holocelulose, valor este mais alto que o obtido para a produção de lenho (35\%). Portanto, a baixa eficiência de uso de $\mathrm{K}$ na progênie 2 foi mais acentuada ainda quando se analisou a produção de holocelulose.
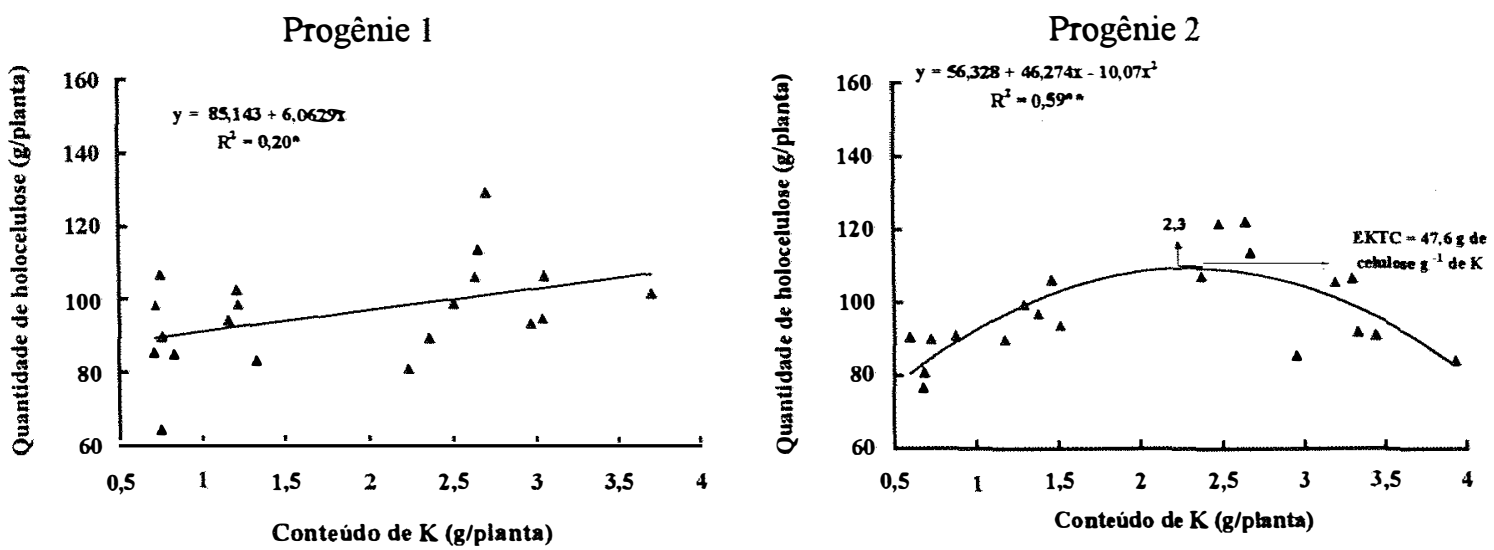

Progênie 3
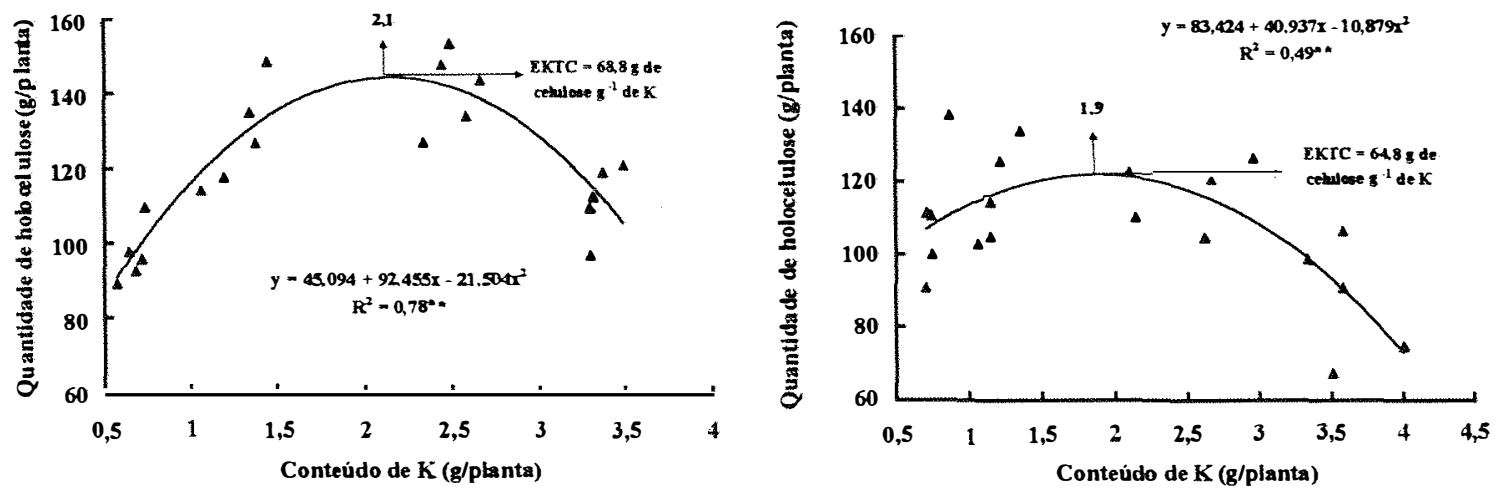

Figura 28. Relação entre a quantidade de holocelulose produzida e o conteúdo de potássio nas progênies de Eucalyptus grandis. 


\subsection{Putrescina e poliaminas}

O aparecimento de manchas necróticas nas folhas de plantas deficientes em potássio é resultado do acúmulo tóxico de putrescina. Na figura 29 , foi possível visualizar as poliaminas nas folhas diagnóstico das progênies de $E$. grandis em função das doses de potássio. $\mathrm{O}$ aparecimento das manchas correspondentes à putrescina foi evidente quando as plantas foram cultivadas na ausência de potássio para todos os materiais genéticos e na dose de $58,5 \mathrm{mg} \mathrm{L}^{-1}$ na progênie 3 . Tais resultados corroboram com os obtidos em cevada por Richards \& Coleman (1952), em Phaseolus vulgaris por Crocomo et al. (1974b), Seasamum por Crocomo \& Basso (1974), em Populus moximowiczii por Houman et al. (1991), em Pinus silvestres por Sarjala \& Kaunisto (1993 e 1996), Picea abies por Kaunisto \& Sarjala (1997) e em Musa sp por Zaidan et al. (1999).

A espermidina e a espermina nas folhas das progênies apareceram em quantidades pequenas, independentemente da dose de $\mathrm{K}$ utilizada, não ocorrendo correlações significativas entre estas e a concentração de $\mathrm{K}$ na solução nutritiva. A amplitude de variação encontrada para a espermidina foi de 0,6 a 2,0 $\mu \mathrm{mol} \mathrm{g}^{-1}$ de MS para a progênie $1 ; 0,4$ a 1,8 $\mu \mathrm{mol} \mathrm{g}^{-1}$ de MS para a progênie 2; 0,6 a 2,1 $\mu \mathrm{mol} \mathrm{g}^{-1}$ de MS para a progênie 3 e 0,6 a $2,0 \mu \mathrm{mol} \mathrm{g}^{-1}$ de MS para a progênie 4 . Já em relação a espermina, as variações nas concentrações foram de: $0,4 \mathrm{a} 1,2 \mu \mathrm{mol} \mathrm{g}^{-1}$ de MS para a progênie $1 ; 0,4$ a $1,3 \mathrm{~mol} \mathrm{~g}^{-1}$ de MS para a progênie 2; 0,4 a $1,4 \mu \mathrm{mol} \mathrm{g}^{-1}$ de MS para a progênie 3 e 0,5 a $1,2 \mu \mathrm{mol} \mathrm{g}^{-1}$ de MS para a progênie 4 . Os valores para estas duas aminas foram bem abaixo dos encontrados para a putrescina nas doses de 0 e $58,5 \mathrm{mg}$ de $\mathrm{K} \mathrm{L}^{-1}$. Resultados similares foram obtidos por Sarjala \& Kaunisto (1993 e 1996), que encontraram leve decréscimo na concentração de espermina e espermidina nas acículas de Pinus sylvestris em função da concentração de potássio. Porém, sem nenhum efeito significativo estatisticamente. Entretanto, resultados opostos foram observados em Picea abies, sendo que incrementos nos níveis de espermina ocorreram nas plantas deficientes em K (Kaunisto \& Sarjala, 1997). 


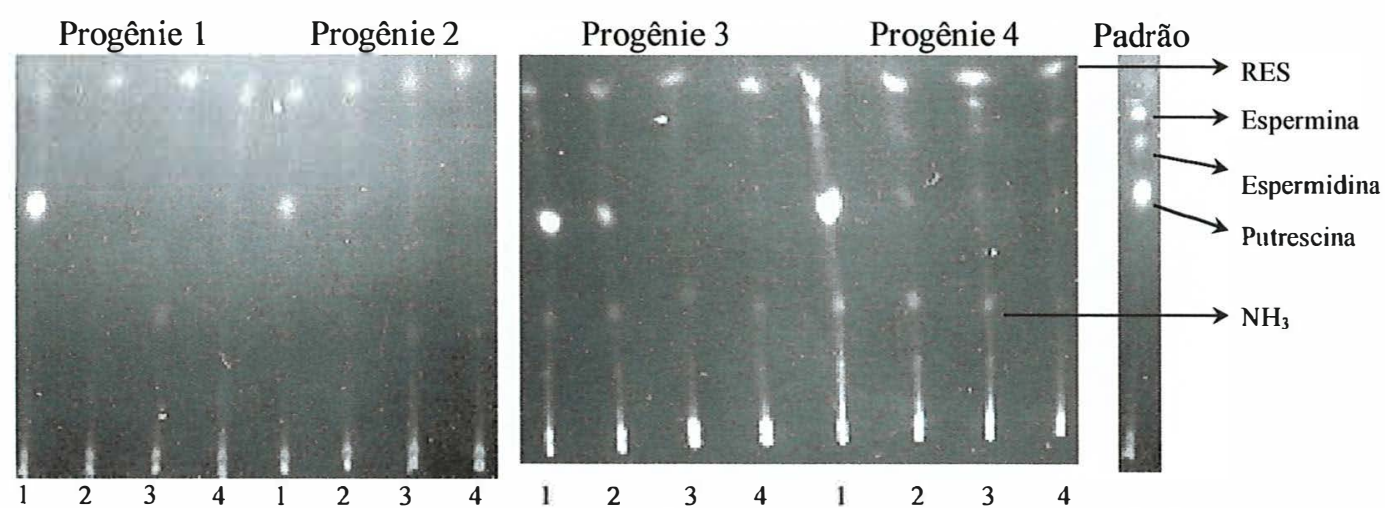

Figura 29. Cromatografia de camada delgada de poliaminas dansiladas nas folhas diagnóstico das progênies de Eucalyptus grandis em função das doses de potássio na solução nutritiva. Os números 1, 2, 3 e 4 correspondem, respectivamente, as doses de $0,58,5,175,5$ e $526,5 \mathrm{mg}$ de $\mathrm{K} \mathrm{L}^{-1}$. A sigla RES significa resíduo de dansil.

Houve interação entre as doses de $\mathrm{K}$ e o materiais genéticos para a concentração de putrescina nas folhas (Tabela 33). Na ausência e na dose de 175,5 mg de $\mathrm{K} \mathrm{L}^{-1}$, as progênies não apresentaram diferenças quanto ao nível de putrescina nas folhas. Mas, na dose de 58,5 $\mathrm{mg}$ de $\mathrm{K} \mathrm{L}^{-1}$, constatou-se que a progênie 3 acumulava mais putrescina nos tecidos quando comparada com a progênie 1, não havendo diferença significativa desta para as progênies 2 e 4 . Já para a dose mais alta de potássio, a progênie 4 apresentou maior concentração da diamina quando confrontada com a progênie 3, a qual não diferiu estatisticamente das demais. Sem levar em consideração a dose de $\mathrm{K}$, as variações na concentração de putrescina foram pequenas e insignificantes entre os materiais genético.

As reduções no nível de putrescina com o aumento do fornecimento de potássio até $175,5 \mathrm{mg} \mathrm{L}^{-1}$, foram de aproximadamente 32 vezes para a progênie 1,27 vezes para a progênie 2,33 vezes para a progênie 3 e 25 vezes para a progênie 4 . Tais resultados também foram encontrados por Houman et al. (1991) em Populus maximowiczii, onde verificaram decréscimo de até 25 vezes na concentração de putrescina quando compararam a ausência de potássio com a dose de $117 \mathrm{mg} \mathrm{L}^{-1}$.

Com aumento do fornecimento de potássio ocorreu uma diminuição na concentração de putrescina até a dose de $175,5 \mathrm{mg} \mathrm{L}^{-1}$, para todos os genótipos. No entanto, para as progênies 1, 2 e 4, não houve alteração da concentração de putrescina com o aumento da dose de $\mathrm{K}$ de 175,5 para $526,5 \mathrm{mg} \mathrm{L}^{-1}$, contrário ao verificado para a 
progênie 3 (Figura 30). A concentração de putrescina nas progênies cultivadas na ausência de potássio estava abaixo das encontradas em tecidos deficientes e necrosados de cevada por Smith (1963), cujos os valores foram e m torno de $140 \mu \mathrm{mol}$ de putrescina $\mathrm{g}^{-1}$ de $\mathrm{MS}$.

Tabela 33. Concentração de putrescina nas folhas diagnóstico das progênies de Eucalyptus grandis em função das doses de potássio na solução nutritiva.

\begin{tabular}{|c|c|c|c|c|c|}
\hline \multirow[t]{2}{*}{ Material genético } & \multicolumn{4}{|c|}{$\overline{\mathrm{K} \text { na solução }\left(\mathrm{mg} \mathrm{L}^{-1}\right)}$} & \multirow[b]{2}{*}{ Média } \\
\hline & 0 & 58,5 & 175,5 & 526,5 & \\
\hline & \multicolumn{5}{|c|}{ Putrescina $\left(\mu \mathrm{mol} \mathrm{g}{ }^{-1}\right.$ de MS $)$} \\
\hline Progênie 1 & 50,7 a A & $7,1 \mathrm{~b} \mathrm{~B}$ & $1,6 \mathrm{aC}$ & $1,8 \mathrm{abc}$ & $15,3 \mathrm{a}$ \\
\hline Progênie 2 & 40,1 a A & 15,8 ab B & $1,5 \mathrm{a} \mathrm{C}$ & $1,4 \mathrm{abc}$ & $14,7 \mathrm{a}$ \\
\hline Progênie 3 & 49,1 a $\mathrm{A}$ & 23,2 a $B$ & $1,3 \mathrm{a} \mathrm{C}$ & $1,3 \mathrm{bc}$ & $18,7 \mathrm{a}$ \\
\hline Progênie 4 & 42,9 a A & $20,2 \mathrm{ab} B$ & $1,7 \mathrm{a} \mathrm{C}$ & 1,9 A C & $16,7 \mathrm{a}$ \\
\hline Média & $45,7 \mathrm{~A}^{4}$ & $16,6 \mathrm{~B}$ & $1,5 \mathrm{c}$ & $1,6 \mathrm{c}$ & \\
\hline
\end{tabular}

Médias seguidas de mesma letra não diferem entre si (minúscula na ventical e maiuscula na horizontal) pelo teste de Tukey ao nível de $5 \%$ de probabilidade.

A Figura 31 mostra a relação entre a concentração de putrescina e a de potássio nas folhas diagnóstico. Em todos os materiais genéticos, houve um decréscimo linear da concentração de putrescina até valores de $5 \mathrm{~g}$ de $\mathrm{K} \mathrm{kg}^{-1}$. Resultados semelhantes foram encontrados por Sarjala e Kaunisto (1996), em Pinus sylvetris, uma vez que para concentrações de $\mathrm{K}$ nas acículas acima de $5 \mathrm{~g} \mathrm{~kg}^{-1}$, ocorreu uma estabilização da concentração de putrescina e para valores de $\mathrm{K}$ menores que $4,3 \mathrm{~g} \mathrm{~kg}^{-1}$, aumentos exponenciais. Em Picea abies, Sarjala \& Kaunisto (1997) também verificaram uma correlação negativa entre a concentração de $\mathrm{K}$ nas folhas e o nivel de putrescina, com relação linear para valores ate $4,2 \mathrm{~g} \mathrm{~kg}^{-1}$. Lauchert \& Wild (1995) constataram uma correlação linear entre a concentração de putrescina e o teor de K nas folhas de Picea abies, sendo que esta correlação estendia-se para valores de $\mathrm{K}$ nas folhas acima do limite da faixa de deficiência, contrário ao observado por Kaunisto \& Sarjala (1997). 
Progênie 1

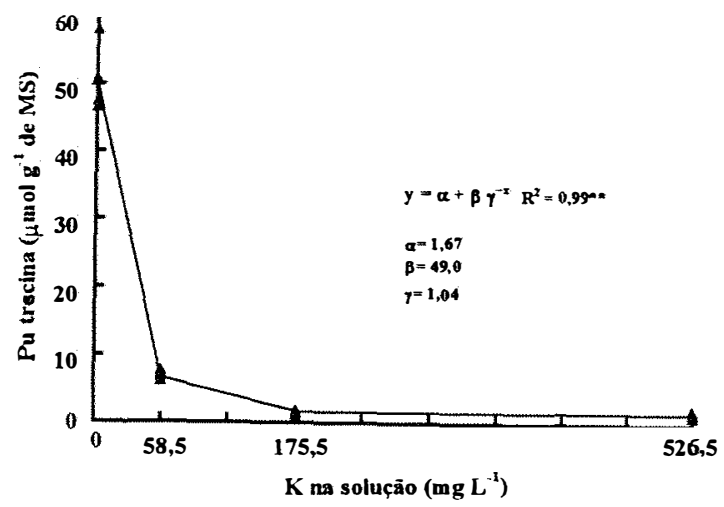

Progênie 3

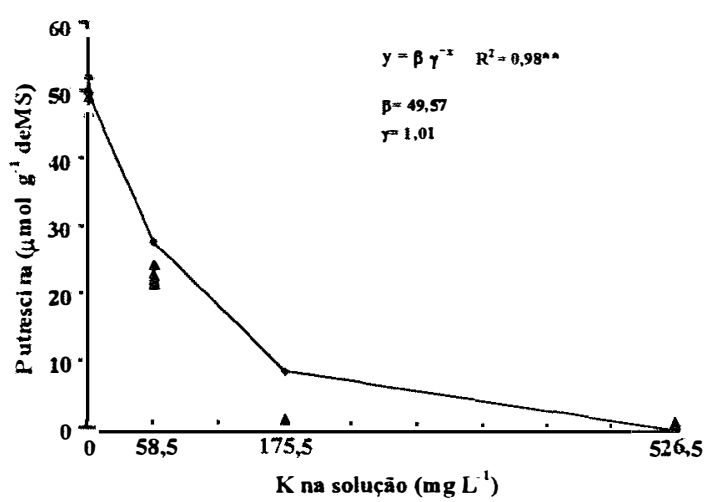

Progênie 2

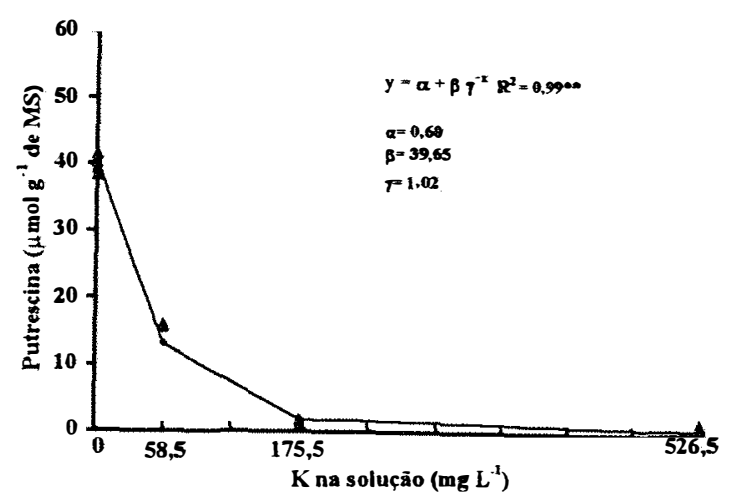

Progênie 4

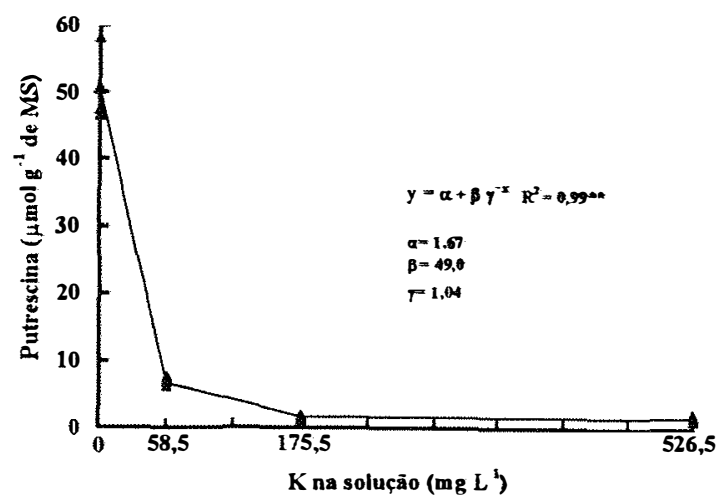

Figura 30. Concentração de putrescina nas folhas diagnóstico das progênies de Eucalyptus grandis em função das doses de potássio na solução nutritiva.

Como era de se esperar, ocorreram incrementos na relação $\mathrm{K} /$ putrescina nas folhas com o aumento da dose de K na solução (Figura 32). Na ausência de potássio, a relação variou de $0,56 \mathrm{~K} / 1,0$ putrescina na progênie 1 até $0,93 \mathrm{~K} / 1,0$ putrescina na progênie 4 , enquanto que na dose mais elevada, $109 \mathrm{~K} / 1$ putrescina na progênie 4 a 168 $\mathrm{K} /$ lputrescina na progênie 3 . Verifica-se ainda que na ausência de potássio, a porcentagem de putrescina em relação a concentração de $\mathrm{K}+\mathrm{Ca}+\mathrm{Mg}$ variou de $23,5 \%$ na progênie $1,16,6 \%$ na progênie $2,22,1 \%$ na progênie 3 e $17,4 \%$ na progênie 4 . Já nas dose mais alta de potássio, as porcentagens de putrescina não ultrapassaram 1\% (Figura 32). 
Nas condições de deficiência de potássio, o déficit de cátion estaria sendo balanceado pela putrescina em até $23,5 \%$, no caso da progênie 1 . Esses resultados são concordantes com os de Murty et al. (1971) e Smith (1984), que verificaram que pelo menos $30 \%$ do déficit de cátion na deficiência de potássio poderia ser balanceado pela putrescina.

Progênie 1

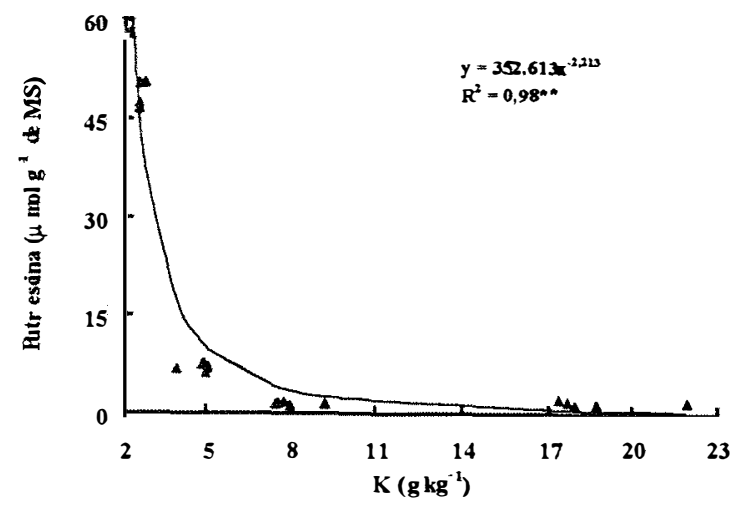

Progênie 3

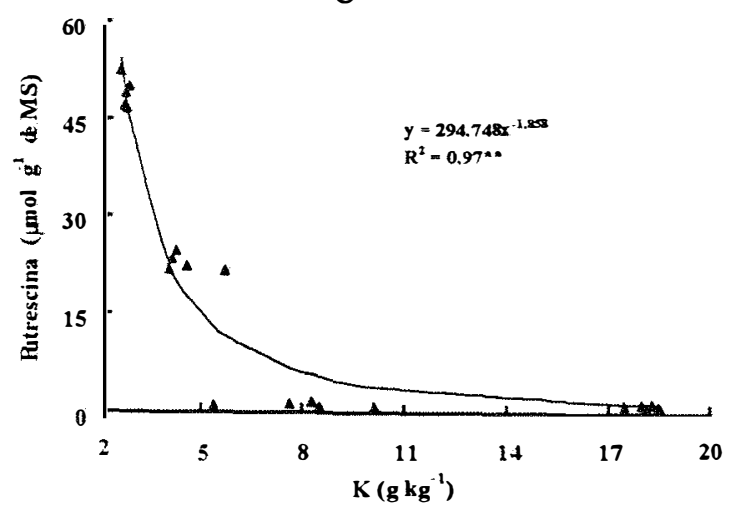

Progênie 2

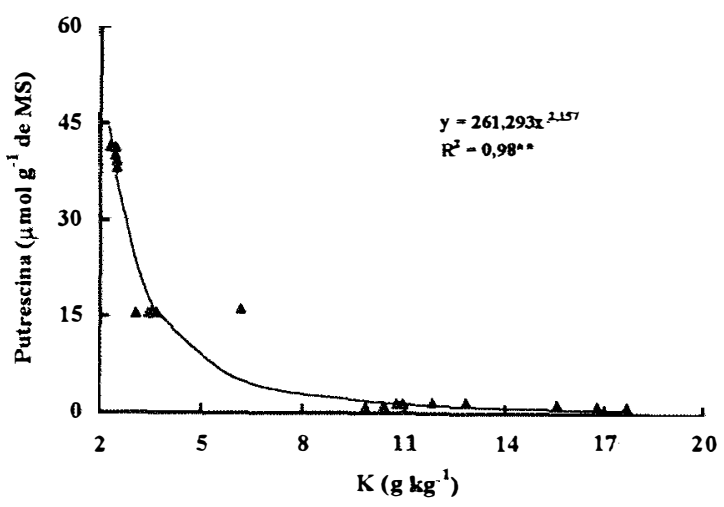

Progênie 4

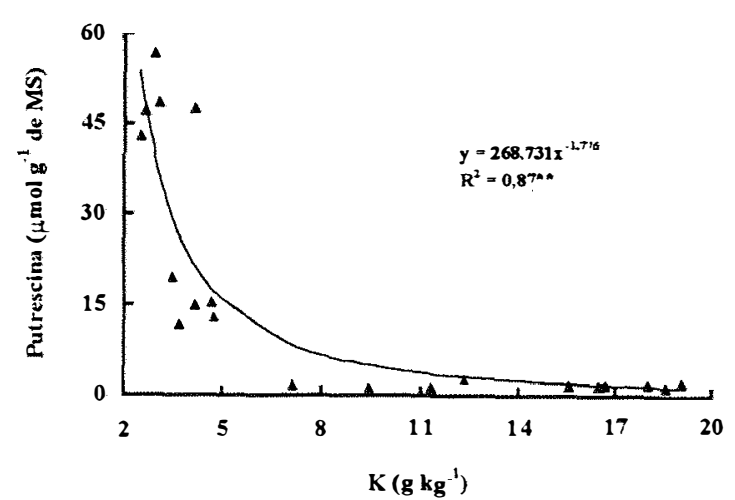

Figura 31. Relação entre a concentração de putrescina e a de potássio nas folhas das progênies de Eucalyptus grandis.

O acúmulo de putrescina em plantas deficientes, pode ser explicado pelo mecanismo proposto por Coleman \& Richards (1956). A carência de potássio altera o balanço interno entre catíons e ânions inorgânico, esperando-se com isso um aumento da acidez do suco celular, o que não corre. Portanto, esses autores sugeriram que o acúmulo de putrescina operaria como um mecanismo para manter o $\mathrm{pH}$ a um valor 
fisiologicamente adequado. $\mathrm{O}$ efeito da putrescina na manutenção do $\mathrm{pH}$ celular é um dos mecanismos propostos da sua atuação, sendo um fator relevante nos estudos de nutrição mineral, especialmente com potássio, conforme demonstrado neste trabalho.

\section{K/Putrescina}

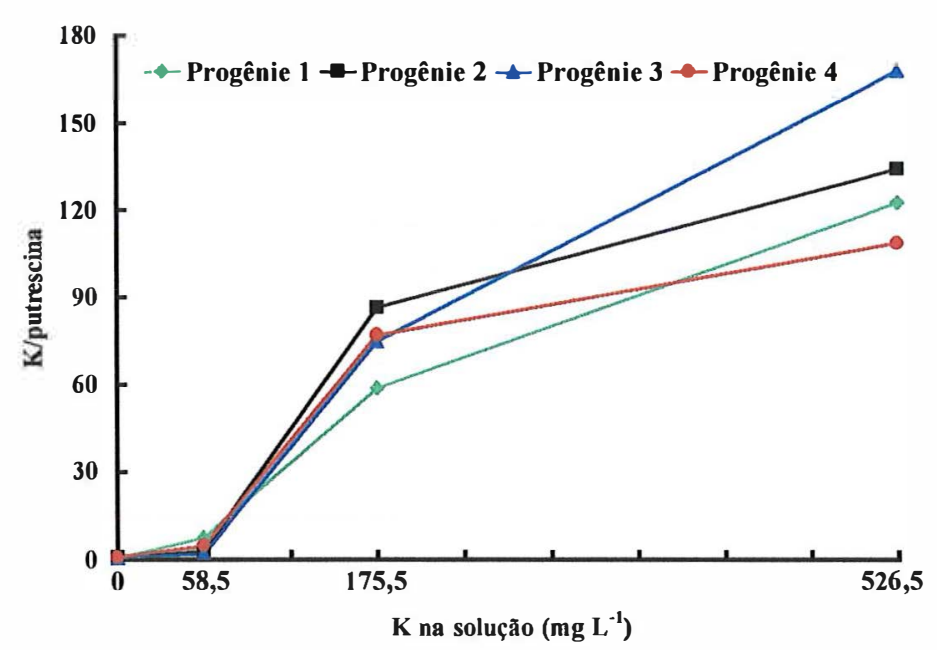

\% putrescina em relação a $\mathrm{K}+\mathrm{Ca}+\mathrm{Mg}$

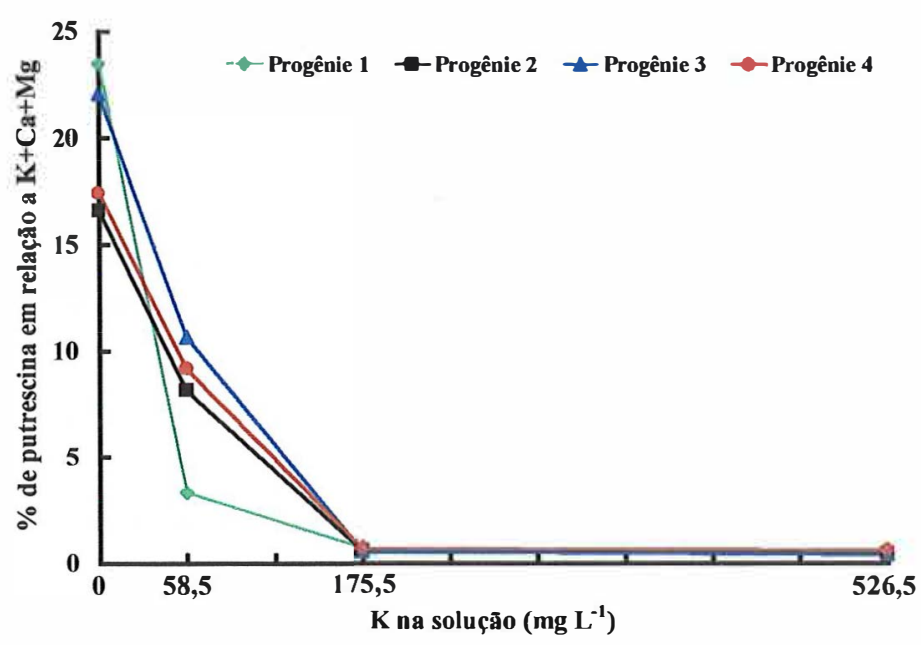

Figura 32. Valores médios da razão K/putrescina e da porcentagem de putrescina em relação a $\mathrm{K}+\mathrm{Ca}+\mathrm{Mg}$ nas folhas diagnóstico das progênies de Eucalyptus grandis em função das doses de potássio na solução nutritiva. 


\subsection{Açúcares solúveis totais}

Houve interação entre as doses e as progênies para a concentração de açúcares solúveis totais (Tabela 34). Não se constatou diferença entre os materiais genéticos para a concentração de açúcar somente na ausência de potássio. $\mathrm{Na}$ dose de $58,5 \mathrm{mg} \mathrm{L}^{-1}$, a progênie 4 apresentou menor nível de carboidrato quando comparada com as progênies 1 e 3 . Na dose de $175,5 \mathrm{mg} \mathrm{L}^{-1}$, as progênies foram afetadas de maneiras distintas, sendo que a progênie 3 apresentou maior capacidade de acúmulo de açúcar nas folhas em relação as demais. A mesma tendência foi verificada na dose mais elevada de potássio, na qual a progênies 3 não diferiu da progênie 2 . Independentemente da dose de potássio, nota-se que houve diferença entre os genótipos, sendo que a progênie 3 apresentou maior capacidade de acumular carboidratos nas folhas em relação as progênies 2 e 4 .

Independente do genótipo, os níveis de açúcares nas folhas foram afetados negativamente pela adição de potássio na solução nutritiva (Tabela 34). Na média, a queda na concentração de açúcares nas folhas foi de $25 \%$ quando comparou-se as plantas cultivadas na ausência e na dose mais alta de potássio. As maiores reduções no nível de carboidrato em relação as doses de potássio foram observadas na progênie 1 , sendo da ordem de $50 \%$ quando confrontou-se a ausência de $\mathrm{K}$ com a dose de $526,5 \mathrm{mg}$ $\mathrm{L}^{-1}$.

As equações de regressões entre as doses de $\mathrm{K}$ e a concentração de açúcar nas folhas, foram significativas para as progênies 1 e 3 . Nos dois materiais genéticos, a diminuição do teor de açúcar ocorreu quando as plantas foram cultivadas em doses crescentes de potássio. No caso das progênies 2 e 4, esse parâmetro não foi significativo (Figura 33). 
Tabela 34. Concentração de açúcares solúveis totais nas folhas diagnóstico das progênies de Eucalyptus grandis em função das doses de potássio na solução nutritiva.

\begin{tabular}{|c|c|c|c|c|c|}
\hline \multirow{3}{*}{$\begin{array}{l}\text { Material } \\
\text { genético }\end{array}$} & \multicolumn{4}{|c|}{ Açúcares solúveis totais $\left(\mathrm{mg} \mathrm{g}^{-1} \mathrm{de} \mathrm{MS}\right)$} & \multirow{3}{*}{ Média } \\
\hline & \multicolumn{4}{|c|}{ K na solução (mg L $\left.{ }^{-1}\right)$} & \\
\hline & 0 & 58,5 & 175,5 & 526,5 & \\
\hline Progênie 1 & 167 a A $(150)^{1}$ & 157 a A (141) & 128 b B (115) & $111 \mathrm{cB}(100)$ & $141 \mathrm{ab}$ \\
\hline Progênie 2 & 145 a $A(115)$ & $142 \mathrm{ab} A(113)$ & 126 b A (100) & $128 \mathrm{ab} A(101)$ & $135 \mathrm{bc}$ \\
\hline Progênie 3 & 161 a $\mathrm{AB}(117)$ & 169 a A (123) & 153 a B (112) & 137 a C (100) & $155 \mathrm{a}$ \\
\hline Progênie 4 & 148 a A (141) & 105 b B (100) & 125 b B (119) & 120 bc B (114) & $124 \mathrm{c}$ \\
\hline Média & $155 \mathrm{~A}(125)^{2}$ & $143 \mathrm{AB}(115)$ & $133 \mathrm{BC}(107)$ & $124 \mathrm{C}(100)$ & \\
\hline
\end{tabular}

Médias seguidas de mesma latra não diferem entre si (minúscula na vertical e maiúscula na horizontal) pelo teste de Tukey ao nível de $5 \%$ de probabilidade; 1 - percentual em relação a menor teor de açúcar para dose de potássio dentro de cada progènie; 2 percertual em relação a menor teor de açúcares para o fator dose de potássio.

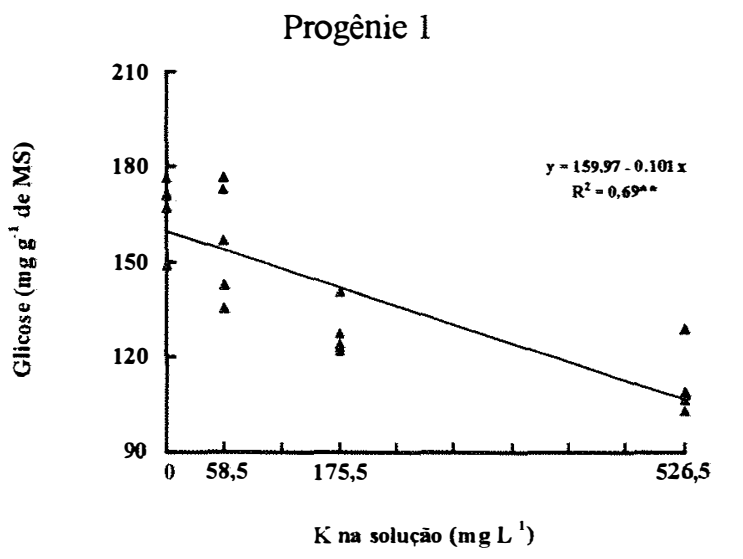

Progênie 3

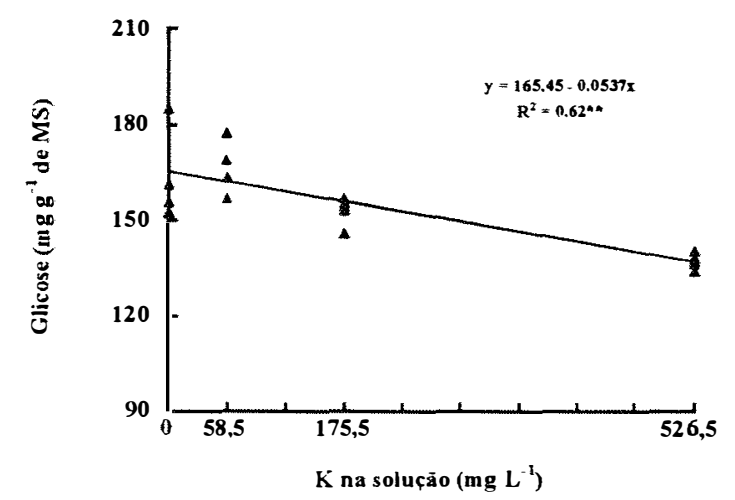

Progênie 2

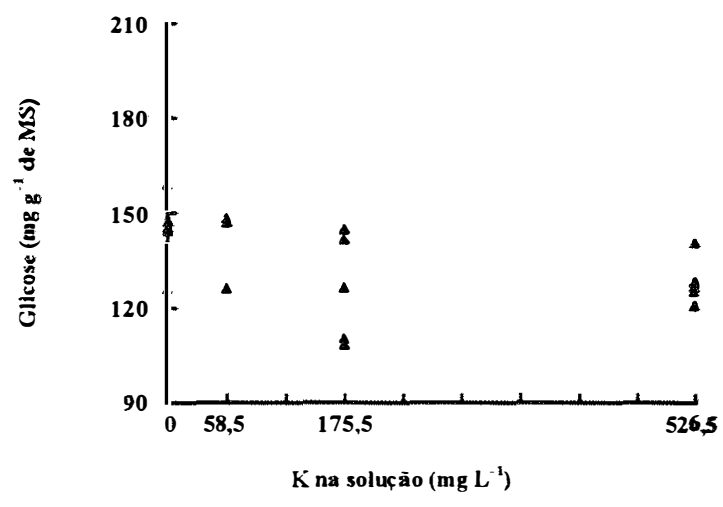

Progênie 4

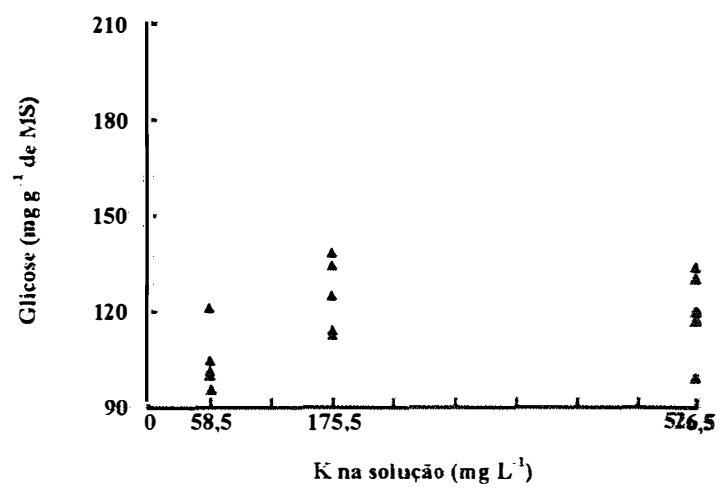

Figura 33. Concentração de açúcares solúveis totais nas folhas diagnóstico das progênies de Eucalyptus grandis em função das doses de potássio na solução nutritiva. 
Respostas semelhantes na concentração de açúcar também foram verificadas em relação a concentração de $\mathrm{K}$ nas folhas diagnóstico (Figura 34). A progênie 1 foi a que apresentou redução mais acentuada na concentração de açúcar com o aumento de $\mathrm{K}$ no tecido foliar. A explicação seria que o maior fornecimento de potássio estaria promovendo uma maior translocação dos açúcares das folhas para o lenho. Evans \& Sorger, 1966 citado por Huber (1985), relatam que normalmente plantas deficientes em potássio apresentam acúmulo de açúcares redutores (glicose, frutose, xilose e outros) e redução dos carboidratos de maior cadeia (amido e sacarose) nas folhas, como consequência da menor atividade da sintetase fosfato sacarose. Marschner (1995), também cita que existe uma relação inversa entre a concentração de potássio nos tecidos e o conteúdo de açúcares, sendo que o papel do potássio estaria ligado ao transporte dos fotossintetados das folhas para os órgãos de armazenamento, principalmente durante o transporte ativo, através da membrana citoplasmática para floema ( $\uparrow \mathrm{K}, \uparrow \uparrow \mathrm{ATP})$, e no fluxo passivo para os tubos crivosos. Em relação ao primeiro processo, maiores concentrações de potássio estimulam a produção de ATP, o qual é necessário para a migração de fotossintetados nos tubos crivosos. No segundo processo, a função do $\mathrm{K}$ seria manter o pH elevado, facilitando com isso, o transporte dos açúcares (Malavolta \& Crocomo, 1982 e Marschner, 1995).

\subsection{Qualidade da madeira}

\subsubsection{Densidade básica}

\subsubsection{Efeito das progênies e das doses de potássio}

Conforme mostra a Tabela 35, houve interação entre as doses e os materiais genéticos para a densidade básica do lenho da região apical, mediana e a média (apical+mediana+basal/3). $\mathrm{Na}$ ausência de potássio e na dose de $58,5 \mathrm{mg}$ de $\mathrm{K} \mathrm{L}^{-1}$, as densidades básicas não variaram em função das progênies. $\mathrm{Na}$ dose de $175,5 \mathrm{mg} \mathrm{L}^{-1}$, o lenho proveniente da progênie 1 foi mais denso em relação as progênies 3 e 4, não havendo diferenças destas para a progênie 2. Na dose mais alta, observou-se que as 
progênies 1 e 4 apresentaram maiores densidades quando confrontada com as outras duas progênies. Sem levar em consideração a dose de K, houve efeito do genótipo para a densidade das três regiões do lenho como também para a densidade média. Na região mediana, a maior densidade foi encontrada na progênie 1 , que diferiu estatisticamente das progênies 2 e 3 . A progênie 1 também apresentou maior densidade da região apical quando confrontada com as progênies 2 e 4 . Para a densidade básica da região basal e a média das três regiões, constatou-se uma superioridade da progênie 1 em relação as demais (Figura 35).

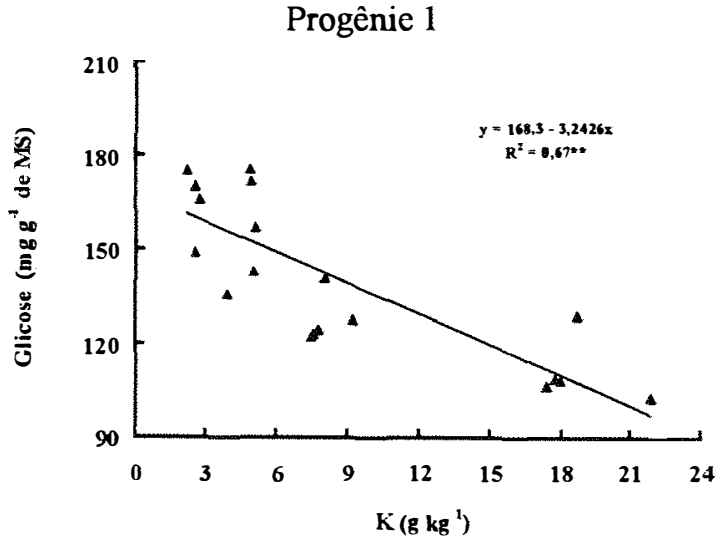

Progênie 3

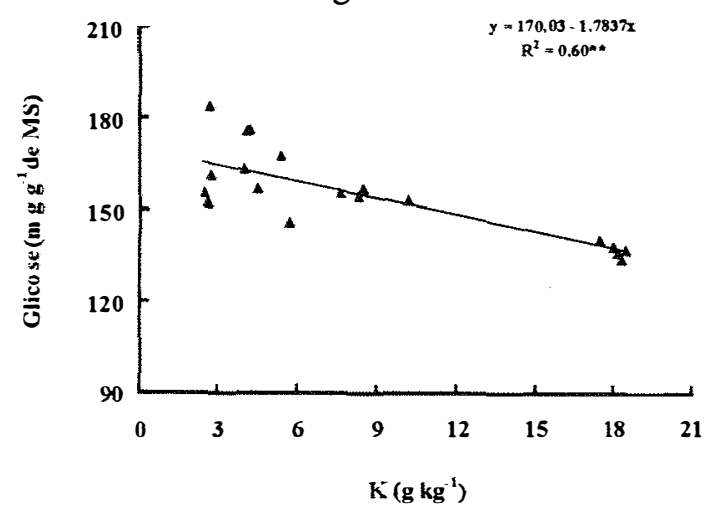

Progênie 2

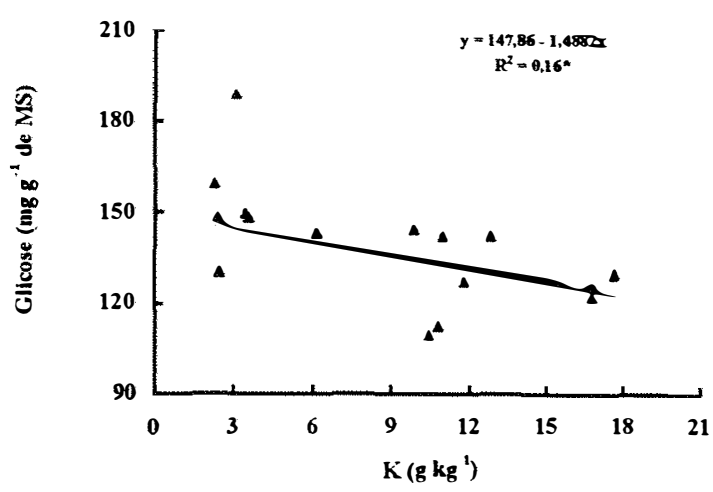

Progênie 4

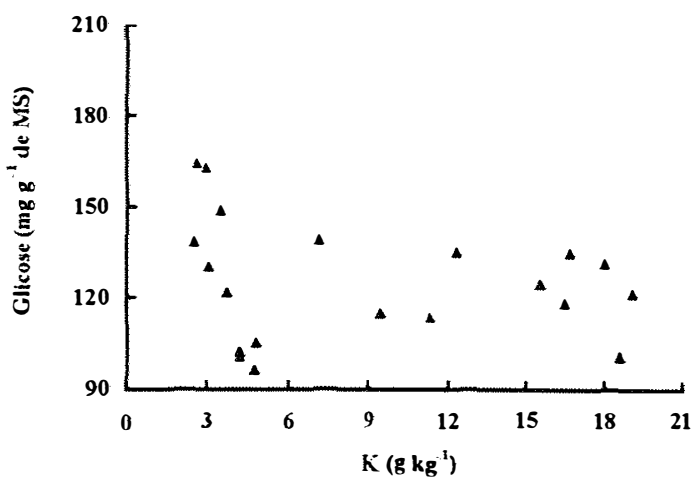

Figura 34 . Relação entre os açúcares solúveis totais e a concentração de potássio nas folhas diagnóstico das progênies de Eucalyptus grandis..

Independente do genótipo, os efeitos das doses de $\mathrm{K}$ sobre a densidade básica foram verificados para a densidade de todas as regiões do lenho, com exceção feita a região basal. A dose mais elevada de potássio proporcionou redução da densidade mediana, apical e a média quando comparada com a dose de $58,5 \mathrm{mg} \mathrm{L}^{-1}$ (Tabela 35). As 
reduções foram em média de $3,5 \%$ para a região mediana, $4,2 \%$ para a região apical e $3,3 \%$ para a média.

A falta de resposta da densidade do lenho basal à aplicação de $\mathrm{K}$ poderia ser explicada da seguinte forma: o lenho dessa região é mais velho quando comparado aos demais, consequentemente ele foi formado antes. Provavelmente sofreu menos a influência das doses de potássio, uma vez que todas as plantas foram cultivadas na dose de $175,5 \mathrm{mg} \mathrm{L}^{-1}$ até a idade de 67 dias após o plantio.

A densidade básica do lenho variou no sentido base-topo, sendo que as maiores densidade foram observadas na região basal. A média geral obedeceu a seguinte ordem decrescente: base $\left(0,45 \mathrm{~g} \mathrm{~cm}^{-3}\right)>$ mediana $\left(0,43 \mathrm{~g} \mathrm{~cm}^{-3}\right)>$ apical $\left(0,41 \mathrm{~g} \mathrm{~cm}^{-3}\right)$.

Tais resultados corroboram com aqueles encontrados por Brasil (1972), Foelkel et al. (1975), Ferreira \& Kageyama (1978), Rocha et al. (1983) Migliorini (1986), Souza et al. (1986), Moraes (1987), Tomazello Filho (1985) Sturion et al. (1987) e Vale et al.(1995), os quais mostraram que a densidade básica da madeira varia em função da taxa de crescimento, nível de produtividade, densidade populacional, espécies, procedências e progênies de Eucalyptus, dentro da mesma árvore no sentido medulacasca e base-topo.

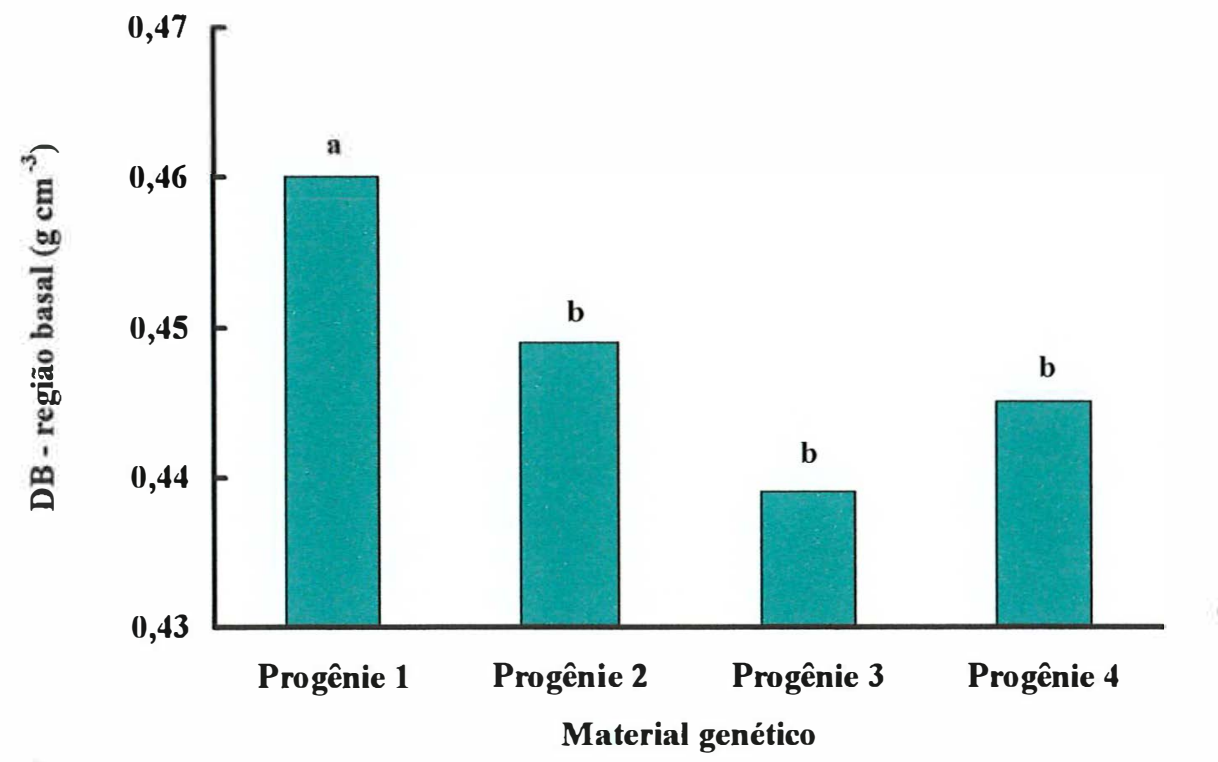

Figura 35. Densidade básica da região basal do lenho das progênies de Eucalyptus grandis (médias seguidas da mesma letra não diferem entre si ao nivel de 5\% de probabilidade pelo teste de Tukey). 
Os resultados mostram respostas distintas dos materiais genéticos, em função da variação da quantidade de potássio na solução (Figura 36). Na progênie 4, a densidade não foi influenciada pela adição de $\mathrm{K}$ na solução. A progênie 1 foi a única em que se verificou acréscimos da densidade da região mediana e apical com o aumento das doses de $\mathrm{K}$ até $175,5 \mathrm{mg} \mathrm{L}^{-1}$. No entanto, na progênie 2, praticamente não houve alteração da densidade até essa dose. Na progênie 3, a densidade da região apical diminuiu linearmente com o maior suprimento de $\mathrm{K}$.

Tabela 35. Densidade básica do lenho na região mediana, apical e a média das progênies de Eucalyptus grandis em função das doses de potássio na solução nutritiva.

\begin{tabular}{|c|c|c|c|c|c|}
\hline \multirow{2}{*}{$\begin{array}{l}\text { Material } \\
\text { genético }\end{array}$} & \multicolumn{4}{|c|}{$\overline{\mathrm{K} \text { na solução }\left(\mathrm{mg} \mathrm{L}^{-1}\right)}$} & \multirow[b]{2}{*}{ Média } \\
\hline & 0 & 58,5 & 175,5 & 526,5 & \\
\hline & \multicolumn{5}{|c|}{$\mathrm{DB}\left(\mathrm{g} \mathrm{cm}^{-3}\right)$ - região mediana } \\
\hline Progênie l & 0,428 a B $(100)^{1}$ & 0,450 a A (105) & 0,463 a A (108) & 0,450 a A (105) & $0,447 \mathrm{a}$ \\
\hline Progênie 2 & 0,425 a $\mathrm{AB}(109)$ & 0,443 a A (113) & 0,442 ab A (113) & 0,390 b B (100) & $0,425 \mathrm{~b}$ \\
\hline Progênie 3 & 0,432 a A (106) & 0,436 a A (107) & 0,408 c A $(100)$ & 0,423 ab A (104) & $0,425 \mathrm{~b}$ \\
\hline Progênie 4 & 0,433 a A (100) & 0,432 a A (100) & 0,433 b A (100) & 0,438 a A (101) & $0,434 \mathrm{ab}$ \\
\hline \multirow[t]{2}{*}{ Média } & $0,429 \mathrm{AB}(101)^{2}$ & 0,440 A $(103)$ & $0,436 \mathrm{AB}(102)$ & $0,425 \mathrm{~B}(100)$ & \\
\hline & \multicolumn{5}{|c|}{$\mathrm{DB}\left(\mathrm{g} \mathrm{cm}^{-3}\right)$ - região apical } \\
\hline Progênie 1 & 0,406 a B (100) & 0,427 a $\mathrm{AB}(105)$ & 0,434 a A (107) & 0,423 a $\mathrm{AB}(104)$ & 0,422 a \\
\hline Progênie 2 & 0,403 a A (104) & 0,411 a A. (106) & 0,411 ab A (106) & 0,387 b A $(100)$ & $0,403 \mathrm{~b}$ \\
\hline Progênie 3 & 0,414 a $\mathrm{AB}(106)$ & 0,433 a $A(111)$ & 0,404 b $A B(103)$ & 0,390 b B (100) & $0,410 \mathrm{ab}$ \\
\hline Progênie 4 & 0,392 a A (100) & 0,411 a A (105) & 0,401 b A (102) & 0,412 ab A (105) & $0,404 \mathrm{~b}$ \\
\hline \multirow[t]{2}{*}{ Média } & $0,404 \mathrm{~B}(100)$ & 0,420 A $(104)$ & $0,412 \mathrm{AB}(102)$ & $0,403 \mathrm{~B}(100)$ & \\
\hline & \multicolumn{5}{|c|}{$\mathrm{DB}\left(\mathrm{g} \mathrm{cm}^{-3}\right)-$ media $^{2}$} \\
\hline Progênie 1 & 0,426 a B (100) & 0,447 a A (105) & 0,456 a A (107) & 0,444 a A (104) & $0,443 \mathrm{a}$ \\
\hline Progênie 2 & 0,424 a $\mathrm{AB}(104)$ & 0,436 a A (107) & 0,436 ab A (107) & 0,408 b B (100) & $0,426 b$ \\
\hline Progênie 3 & 0,430 a $A(104)$ & 0,440 a $\mathrm{A}(106)$ & 0,414 b A (100) & 0,414 b A $(100)$ & $0,426 \mathrm{~b}$ \\
\hline Progênie 4 & 0,425 a A $(100)$ & 0,429 a A (101) & 0,426 b $A(100)$ & 0,431 ab A (101) & $0,428 \mathrm{~b}$ \\
\hline Média & $0,426 \mathrm{~B}(100)$ & 0,438 A (103) & $0,433 \mathrm{AB}(102)$ & $0,424 \mathrm{~B}(100)$ & \\
\hline
\end{tabular}

Médias seguidas de mesma letra não diferem entre si (minúscula na vertical e maiúscula na horizontal) pelo teste de Tukey ao nivel de $5 \%$ de probabilidade: 1- percentual em relação a menor densidade básica na dose de potássio dentro de cada progênie; 2 percentual em relação a menor densidade básica para o fátor potássio.

A redução de densidade apical na maior dose de $\mathrm{K}$ em relação a testemeunha foi de aproximadamente $8 \%$, no caso da progênie 3 (Figura 36). Balloni (1984) também verificou redução da densidade básica do lenho de Pimus caribaea var. bahamensis com 13 anos, através da adubação potássica, o que corrabora o presente trabalho. No entanto, em termos percentuais a redução foi menor, 4,5\%. Resultados similares foram obtidos 
por Gray \& Zeeuw (1975) para Pinus radiata, com decréscimos da densidade básica da madeira juvenil e adulta mediante à aplicação de $\mathrm{K}$. No entanto, esses resultados são discordante para as progênies 1 e 2 . Para a progênie 1 , houve ganhos de $5,4 \%$ na densidade apical com o suprimento de $\mathrm{K}$ até $175,5 \mathrm{mg} \mathrm{L}^{-1}$, enquanto que na progênie 2 , foi constatado pequeno efeito sobre a densidade.

Normalmente, o que se tem observado em relação a densidade básica da madeira é que a adubação, seja através da aplicação conjunta de NPK ou isolada, especialmente de $\mathrm{N}$, tem provocado redução significativa da densidade em várias espécies como: E. regnans (Higgs \& Rudman, 1973); Pimus elliotti (Willians \& Hamilton, 1961; Woollons et al., 1995); Pinus caribaea (Balloni, 1984; Brito, 1985), Picea rubens (Shepard, 1982); Picea abies (Weetman, 1971) e Pseudotsuga menziensii (Jozsa \& Brix, 1989).
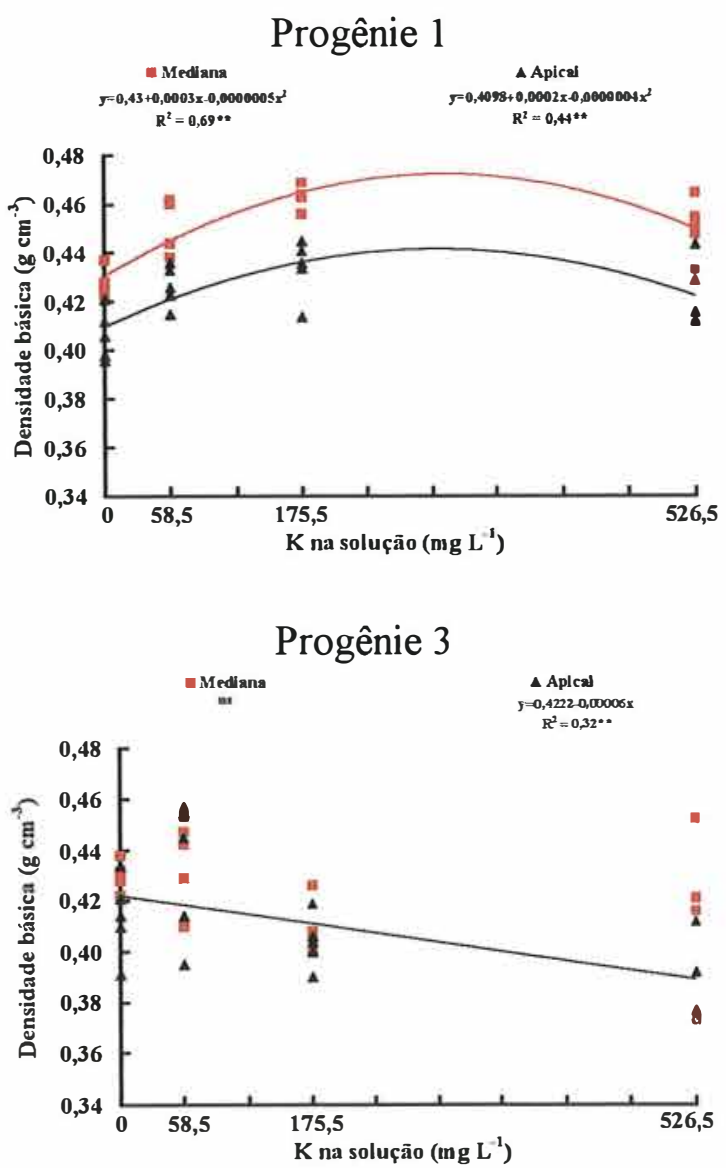

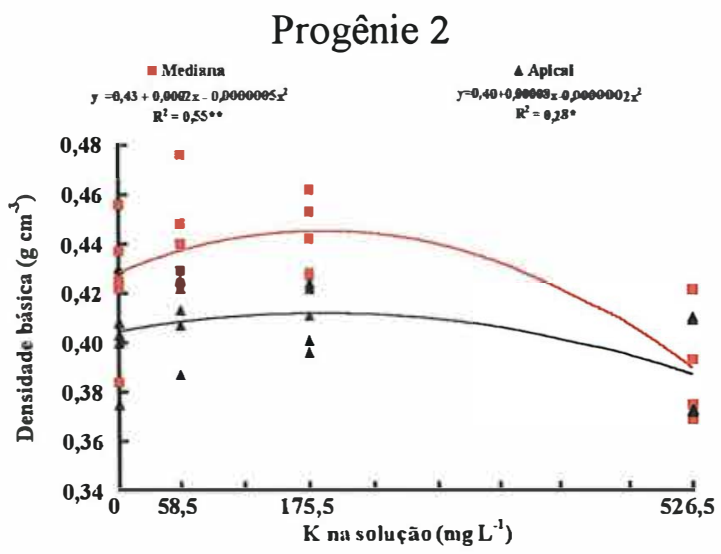

Progênie 4

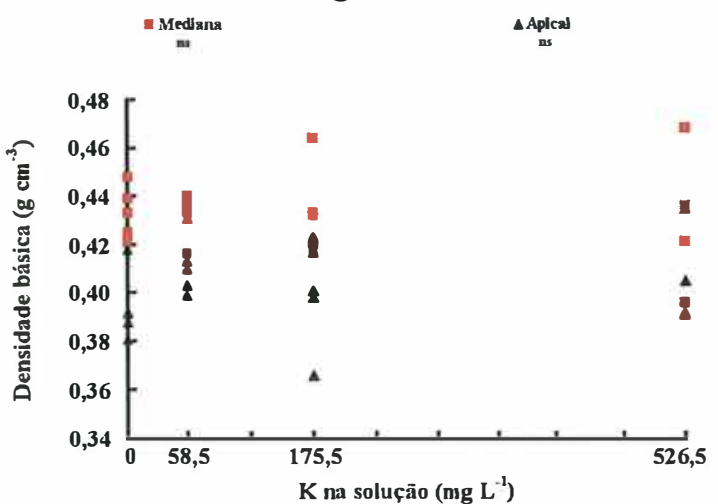

Figura 36. Densidade básica da região mediana e apical do lenho das progênies de Eucalyptus grandis em função das doses de potássio na solução nutritiva. 
A densidade básica teve ser confrontada com os ganhos de produção obtidos com a aplicação dos nutrientes, buscando sempre maiores produtividades associadas a uma menor redução da densidade. Por exemplo, no caso da progênie 3, os ganhos de produtividade com a adição de $175,5 \mathrm{mg} \mathrm{L}^{-1}$ foram de $46 \%$ em relação a testemunha, o que compensaria a redução de somente $2 \%$ na densidade apical. Por outro lado, na progênie 1 , a aplicação de $\mathrm{K}$ não seria vantajosa, porque não resultou em ganhos de produção de lenho, embora tenha aumentado em até $8,5 \%$ e 5,5\% a densidade da região mediana e apical, respectivamente.

\subsubsection{Efeito da concentração de potássio e dos macronutrientes nas folhas diagnóstico e no lenho}

A Tabela 36 mostra os coeficientes de correlações de Pearson das concentrações dos macronutrientes nas folhas e no lenho e a densidade básica nas diferentes posições do caule. Na progênie 1 , as correlações que mais se destacaram foram entre a densidade da região mediana e a concentração de $\mathrm{K}$ e $\mathrm{Mg}$ no lenho ( $\mathrm{r}$ = $0,63 ; \mathrm{r}=-0,62)$, e a concentração de $\mathrm{Ca}$ e $\mathrm{Mg}$ nas folhas diagnóstico $(\mathrm{r}=-0,75 ; \mathrm{r}=-$ $0,72)$ e a concentração de $\mathrm{Mg}$ no lenho $(\mathrm{r}=-0,62)$. Com o aumento das concentrações de cálcio e magnésio ocorreu decréscimo na densidade básica, sendo que efeitos opostos foram observados em relação ao potássio. Na progênie 3, o aumento na concentração de $N(r=0,76)$ e $P(r=0,72)$ nas folhas diagnóstico promoveu incrementos na densidade da região apical.

As mesmas tendências verificadas para a densidade básica em função das doses de potássio, também foram observadas quando comparou-se as concentrações de $\mathrm{K}$ no tecido foliar (Figura 37). 
Tabela 36. Coeficientes de correlações de Pearson entre a concentração dos macronutrientes nas folhas diagnóstico e no lenho e a densidade básica em diferentes posições do lenho das progênies de Eucalyptus grandis.

\begin{tabular}{|c|c|c|c|c|c|c|c|c|c|c|c|c|}
\hline \multirow{2}{*}{$\begin{array}{l}\text { Material } \\
\text { genético }\end{array}$} & \multicolumn{2}{|c|}{$\mathrm{N}$} & \multicolumn{2}{|c|}{$\mathrm{P}$} & \multicolumn{2}{|c|}{$\bar{K}$} & \multicolumn{2}{|c|}{$\mathrm{Ca}$} & \multicolumn{2}{|c|}{$\mathrm{Mg}$} & \multicolumn{2}{|c|}{$\mathrm{S}$} \\
\hline & $\mathrm{FD}^{1}$ & $\mathrm{~L}^{2}$ & FD & $\mathrm{L}$ & FD & $\mathrm{L}$ & FD & $\mathrm{L}$ & FD & $\mathrm{L}$ & FD & $\mathrm{L}$ \\
\hline & \multicolumn{12}{|c|}{ Região apical } \\
\hline Progênie 1 & ns & 0,49 & ns & ns & 0,37 & $0,45=$ & $\mathrm{ns}$ & $\mathrm{ns}$ & $-0,52$ & $-0,44=$ & $-0,54 \cdots$ & $\mathrm{ns}$ \\
\hline Progênie 2 & ns & ns & ns & ns & ns & ns & $\mathrm{ns}$ & $-0,41$ * & ns & $0,46 *$ & ns & ns \\
\hline Progênie 3 & $0,76 *$ & 0,48 & $0,72 * *$ & ns & $-0,53$ & $-0,57 \cdots$ & $\mathrm{ns}$ & ns & $0,56 *$ & $\mathrm{~ns}$ & $0,53 *$ & ns \\
\hline Progênie 4 & ns & ns & ns & ns & ns & ns & ns & ns & ns & ns & ns & $-0,45$ \\
\hline \multirow[t]{2}{*}{ Todos } & $0,22=$ & $0,26^{*}$ & $0,25 *$ & $0,24^{*}$ & ns & ns & ns & $\mathrm{ns}$ & $\mathrm{ns}$ & $0,27^{*}$ & ns & ns \\
\hline & \multicolumn{12}{|c|}{ Região mediana } \\
\hline Progênie 1 & ns & $0,53 *$ & ns & ns & ns & $0,63 *=$ & $-0,75 * *$ & $-0,50$ & $-0,72=$ & $-0,62=$ & $-0,62 * *$ & $-0,50$ \\
\hline Progênie 2 & $0,58 * *$ & 0,42 . & $0,46=$ & ns & $-0,40$ & ns & ns & ns & $\mathrm{ns}$ & $0,56=$ & ns & ns \\
\hline Progênie 3 & $0,49 \cdot$ & ns & ns & ns & ns & ns & $\mathrm{ns}$ & ns & ns & ns & ns & $\mathrm{ns}$ \\
\hline Progênie 4 & ns & ns & ns & ns & ns & ns & ns & ns & ns & ns & ns & $-0,42$ \\
\hline \multirow[t]{2}{*}{ Todos } & $0,28 *$ & ns & $0,24^{*}$ & ns & ns & ns & ns & ns & ns & ns & ns & ns \\
\hline & \multicolumn{12}{|c|}{ Região basal } \\
\hline Progênie 1 & ns & $0,49 *$ & ns & ns & ns & 0,45 & $-0,60 * *$ & $-0,42=$ & $-0,62 * *$ & $-0,41=$ & $-0,43$ & $\mathrm{~ns}$ \\
\hline Progênie 2 & ns & ns & ns & ns & ns & ns & ns & ns & ns & ns & ns & ns \\
\hline Progênie 3 & ns & ns & ns & ns & ns & $-0,47=$ & ns & ns & $0,40 *$ & ns & $0,38 *$ & ns \\
\hline Progênie 4 & ns & ns & ns & ns & ns & ns & ns & ns & ns & ns & ns & ns \\
\hline \multirow[t]{2}{*}{ Todos } & ns & ns & ns & ns & ns & ns & ns & ns & ns & ns & ns & ns \\
\hline & \multicolumn{12}{|c|}{ Média } \\
\hline Progênie 1 & ns & $0,57 *$ & ns & $\mathrm{ns}$ & $\mathrm{ns}$ & $0,56^{*}$ & $-0,63=$ & $-0,40$ & $-0,69 * *$ & $-0,54=$ & $-0,40 *$ & $-0,61 *$ \\
\hline Progênie 2 & $0,51^{*}$ & $0,40 *$ & $0,44 *$ & ns & ns & ns & ns & ns & ns & $0,51=$ & ns & ns \\
\hline Progênie 3 & $0,65=*$ & $0,41^{*}$ & $0,56 * *$ & ns & $-0,43$ & $-0,58 * *$ & ns & ns & $0,53=$ & ns & $0,49 *$ & ns \\
\hline Progênie 4 & ns & ns & ns & ns & ns & ns & ns & ns & ns & ns & ns & $-0,44$ \\
\hline Todos & 0,27 . & $0,26 *$ & $0,26 *$ & ns & ns & ns & ns & ns & ns & $0,24 *$ & ns & ns \\
\hline
\end{tabular}


Progênie 1

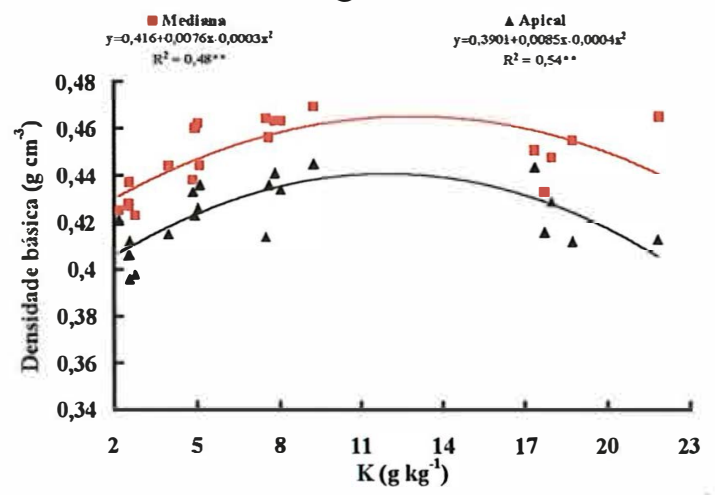

Progênie 3

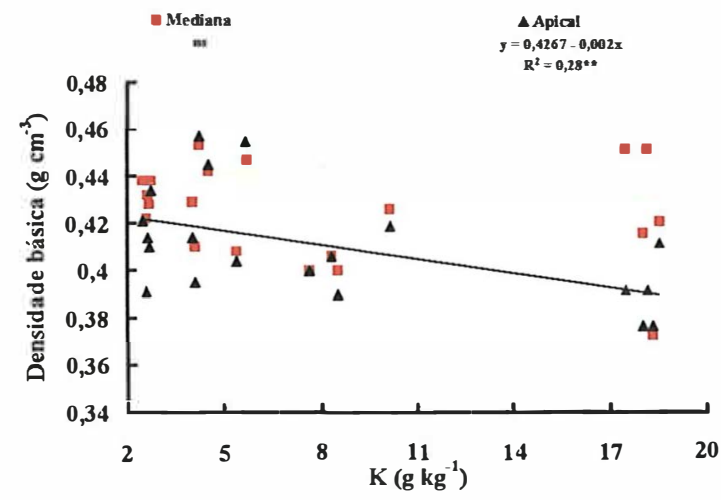

Progênie 2

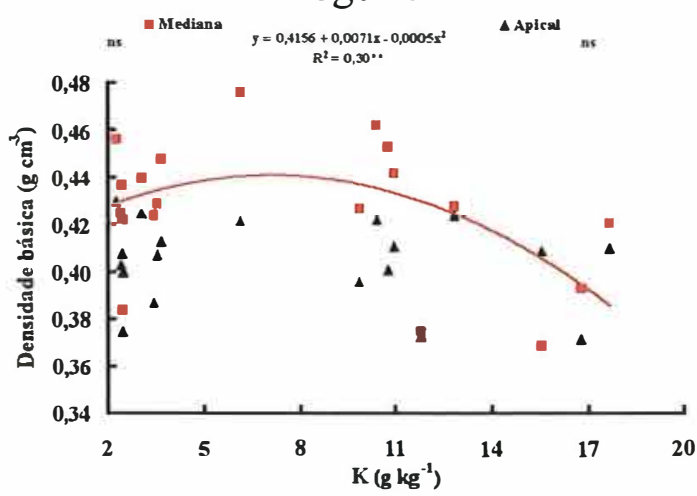

Progênie 4

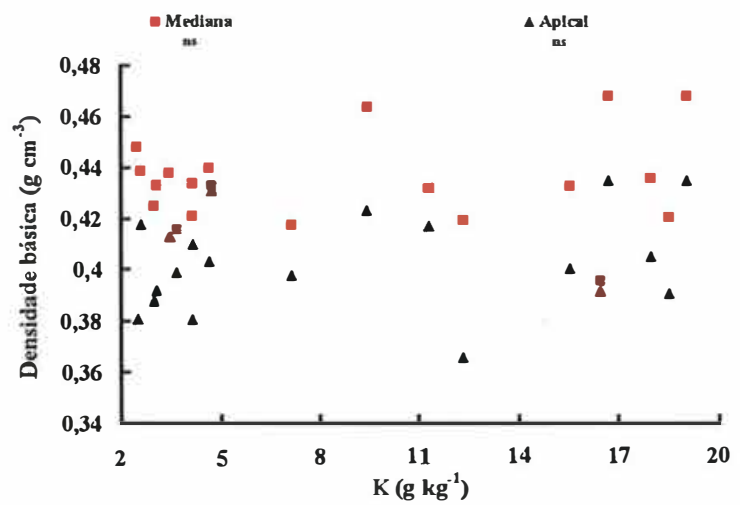

Figura 37. Densidade básica do lenho da região mediana e apical das progênies de Eucalyptus grandis em função das concentrações de potássio nas folhas diagnóstico.

\subsubsection{Efeito das relações $\mathrm{N} / \mathrm{K}, \mathrm{K} / \mathrm{P}, \mathrm{K} / \mathrm{Ca}, \mathrm{K} / \mathrm{Mg}$ e $\mathrm{K} / \mathrm{Ca}+\mathrm{Mg}$ nas folhas diagnóstico e no lenho}

Os efeitos das razões entre o potássio e os outros macronutrientes nas folhas diagnóstico e no lenho sobre a densidade básica são apresentados na Tabela 37. Os efeitos foram mais relevantes na progênie 1 em relação as demais. Neste genótipo, verificou-se que quanto maior a concentração de $\mathrm{N}$ em relação a de potássio nas folhas diagnóstico menor era a densidade básica da região apical $(r=-0,59)$ e mediana $(r=-$ $0,68)$. As tendências foram contrárias para a razão $\mathrm{K} / \mathrm{P}(\mathrm{r}=0,62), \mathrm{K} / \mathrm{Ca}(\mathrm{r}=0,66), \mathrm{K} / \mathrm{Mg}$ $(r=0,65)$ e $\mathrm{K} / \mathrm{Ca}+\mathrm{Mg}(\mathrm{r}=0,65)$, principalmente no lenho. 
Tabela 37. Coeficientes de correlações de Pearson entre a razão $\mathrm{N} / \mathrm{K}, \mathrm{K} / \mathrm{P}, \mathrm{K} / \mathrm{Ca}, \mathrm{K} / \mathrm{Mg}$ e $\mathrm{K} / \mathrm{Ca}+\mathrm{Mg}$ nas folhas diagnóstico e no lenho e a densidade básica do lenho em diferentes posições nas progênies de Eucalyptus grandis.

\begin{tabular}{|c|c|c|c|c|c|c|c|c|c|c|}
\hline \multirow{2}{*}{$\begin{array}{l}\text { Material } \\
\text { genético }\end{array}$} & \multicolumn{2}{|c|}{$\mathrm{N} / \mathrm{K}$} & \multicolumn{2}{|c|}{$\mathrm{K} / \mathrm{P}$} & \multicolumn{2}{|c|}{$\mathrm{K} / \mathrm{Ca}$} & \multicolumn{2}{|c|}{$\mathrm{K} / \mathrm{Mg}$} & \multicolumn{2}{|c|}{$\mathrm{K} / \mathrm{Ca}+\mathrm{Mg}$} \\
\hline & $\mathrm{FD}^{1}$ & $\mathrm{~L}^{2}$ & FD & $\mathrm{L}$ & FD & $\mathrm{L}$ & FD & $\mathrm{L}$ & FD & $\mathrm{L}$ \\
\hline & \multicolumn{10}{|c|}{ Região apical } \\
\hline Progênie I & $-0,59 * *$ & $-0,49 *$ & ns & $0,47 *$ & ns & $0,46^{*}$ & ns & $0,45^{*}$ & ns & $0,44^{*}$ \\
\hline Progênie 2 & ns & ns & ns & ns & ns & ns & ns & $-0,41^{*}$ & ns & ns \\
\hline Progênie 3 & $0,49 *$ & $0,40 *$ & $-0,58 * *$ & $-0,49 *$ & $-0,52 *$ & $-0,56 * *$ & $-0,54^{*}$ & $-0,50 *$ & $-0,53 *$ & $-0,57 * *$ \\
\hline Progênie 4 & ns & ns & ns & ns & ns & Ns & ns & ns & ns & ns \\
\hline \multirow[t]{2}{*}{ Todos } & ns & ns & ns & ns & ns & ns & ns & ns & ns & ns \\
\hline & \multicolumn{10}{|c|}{ Região mediana } \\
\hline \multirow{6}{*}{$\begin{array}{l}\text { Progênie } 1 \\
\text { Progênie } 2 \\
\text { Progênie } 3 \\
\text { Progênie } 4 \\
\text { Todos } \\
\end{array}$} & $-0,68 * *$ & $-0,58^{* *}$ & $0,47^{*}$ & $0,62 * *$ & $0,46^{*}$ & $0,66^{* *}$ & $0,45^{*}$ & $0,65^{* *}$ & $0,46^{*}$ & $0,65^{* *}$ \\
\hline & ns & ns & $-0.5 I^{*}$ & ns & $-0,37 *$ & ns & $-0,49 *$ & $-0,52 *$ & $-0,42 *$ & ns \\
\hline & ns & ns & ns & $-0,44^{*}$ & ns & ns & ns & ns & ns & ns \\
\hline & ns & ns & ns & ns & ns & ns & ns & ns & ns & ns \\
\hline & ns & ns & ns & ns & ns & ns & ns & ns & ns & ns \\
\hline & \multicolumn{10}{|c|}{ Média } \\
\hline Progênie I & $-0,66 * *$ & $-0,55 *$ & ns & $0,57 * *$ & $\overline{\mathrm{ns}}$ & $0,60 * *$ & $\overline{\mathrm{ns}}$ & $0,56^{* *}$ & ns & $0,58 * *$ \\
\hline Progênie 2 & ns & ns & $-0,42^{*}$ & ns & ns & ns & $-0,40 *$ & $-0,46^{*}$ & ns & ns \\
\hline Progênie 3 & $0,49 *$ & $0,45^{*}$ & $-0,44^{*}$ & $-0,57 * *$ & $-0,40 *$ & $-0,53 * *$ & $-0,4 I^{*}$ & $-0,52^{*}$ & $-0,40 *$ & $0,52 *$ \\
\hline Progênie 4 & ns & ns & ns & ns & ns & ns & ns & ns & ns & ns \\
\hline Todos & ns & ns & ns & ns & ns & ns & ns & ns & ns & ns \\
\hline
\end{tabular}

\subsubsection{Parâmetros anatômicos}

\subsubsection{Comprimento e largura das fibras}

\subsection{Efeito das progênies e das doses de potássio}

Houve interação entre as doses de potássio $\mathrm{e}$ as progênies para o comprimento e a largura das fibras (Tabela 38). Para a largura, constatou-se diferença entre as progênies somente na dose de $526,5 \mathrm{mg} \mathrm{L}^{-1}$. A progênie 2 apresentou fibras mais longas que a progênie 1 , a qual não diferiu das outras. Em relação ao comprimento, só não houve diferença entre os materiais genéticos quando as plantas foram cultivadas na dose de $58,5 \mathrm{mg} \mathrm{L}^{-1}$. $\mathrm{Na}$ ausência de potássio, as fibras mais curtas foram encontradas na progênie 3. A progênie 1 apresentou fibras menores que as demais, nas doses mais elevadas de potássio. Independente da dose de potássio, as 
progênies 2 e 4 apresentaram fibras mais longas que as progênies 1 e 3 . Nota-se ainda, que as fibras mais compridas foram encontradas nas plantas cultivadas nas doses mais altas, independente do genótipo analisado. Tais resultados também foram verificados por Cutter \& Murphy (1978), através da aplicação de K em Pseudotsuga menziensii x P. berolinensis. Estudo mais recente, mostrou que durante a formação da madeira juvenil de Picea abies, na fase de elongação das células, ocorria um incremento do conteúdo de $\mathrm{K}$ do simplasto (Dunisch et al., 1998). Os autores ainda concluíram que o potássio foi fundamental para a elongação e diferenciação dos traqueídeos.

Tabela 38. Comprimento e largura das fibras das progênies de Eucalyptus grandis em função das doses de potássio na solução nutritiva.

\begin{tabular}{|c|c|c|c|c|c|}
\hline \multirow{2}{*}{$\begin{array}{l}\text { Material } \\
\text { genético }\end{array}$} & \multicolumn{4}{|c|}{$\overline{\mathrm{K} \text { na solução }\left(\mathrm{mg} \mathrm{L}^{-3}\right)}$} & \multirow[b]{2}{*}{ Média } \\
\hline & 0 & 58,5 & 175,5 & 526,5 & \\
\hline & \multicolumn{5}{|c|}{ Comprimento das fibras (mm) } \\
\hline Progênie 1 & 0,820 a A & 0,818 a $\mathrm{A}$ & $0,8 \overline{24 \text { b A }}$ & 0,812 b A & $0,818 b$ \\
\hline Progênie 2 & 0,856 a $\mathrm{AB}$ & 0,844 a B & 0,864 a $\mathrm{AB}$ & 0,884 a A & $0,862 \mathrm{a}$ \\
\hline Progênie 3 & 0,764 b c & 0,830 a B & 0,865 a $\mathrm{AB}$ & 0,868 a A & $0,832 \mathrm{~b}$ \\
\hline Progênie 4 & 0,832 a BC & 0,822 a C & $0,864 \mathrm{a} \mathrm{AB}$ & 0,888 a $\mathrm{A}$ & $0,851 \mathrm{a}$ \\
\hline \multirow[t]{2}{*}{ Média } & $0,818 \mathrm{~B}$ & $0,828 \mathrm{~B}$ & $0,854 \mathrm{~A}$ & $0,863 \mathrm{~A}$ & \\
\hline & \multicolumn{5}{|c|}{ Largura das fibras $(\mu \mathrm{m})$} \\
\hline Progênie 1 & 17,49 a A & 17,58 a $\mathrm{A}$ & 17,79 a A & 17,42 b A & $17,57 \mathrm{a}$ \\
\hline Progênie 2 & 17,07 a B & 17,33 a $\mathrm{B}$ & 18,01 a $A$ & 18,25 a $\mathrm{A}$ & $17,66 \mathrm{a}$ \\
\hline Progênie 3 & 17,29 a A & 17,48 a A & 17,61 a $\mathrm{A}$ & 17,77 ab A & $17,54 \mathrm{a}$ \\
\hline Progênie 4 & 17,11 a A & 17,51 a $\mathrm{A}$ & 17,55 a A & $17,66 \mathrm{ab} A$ & $17,46 \mathrm{a}$ \\
\hline Média & $17,24 \mathrm{c}$ & $17,47 \mathrm{BC}$ & $17,74 \mathrm{AB}$ & $17,77 \mathrm{~A}$ & \\
\hline
\end{tabular}

Médias seguidas de mesma latra não diferem antre si (minúscula na vertical e maiuscula na horizontal) pelo teste de Tukey ao nivel de $5 \%$ de probabilidade.

Os resultados obtidos em relação ao comprimento e largura das fibras podem ser explicados com base em Marschner (1995), segundo o qual, o potássio tem função na osmorregulação. O crescimento das fibras depende do potencial osmótico do vacúolo, causado pelo acúmulo de solutos e da extensibilidade da parede celular. Concentrações elevadas de potássio e açúcares, podem ser responsáveis por até $50 \%$ do potencial osmótico das fibras. Como consequência, o aumento da extensão celular é influenciado pelo acúmulo nas células do íon $\mathrm{K}^{+}$. 
A Figura 38 mostra as equações de regressões entre as doses de $\mathrm{K}$ na solução e o comprimento e a largura das fibras. A progênie 1 foi a única em que esses parâmetros anatômicos não variaram em função das doses de potássio. Nos outros materiais genéticos, o potássio afetou positivamente tanto o comprimento como a largura das fibras.
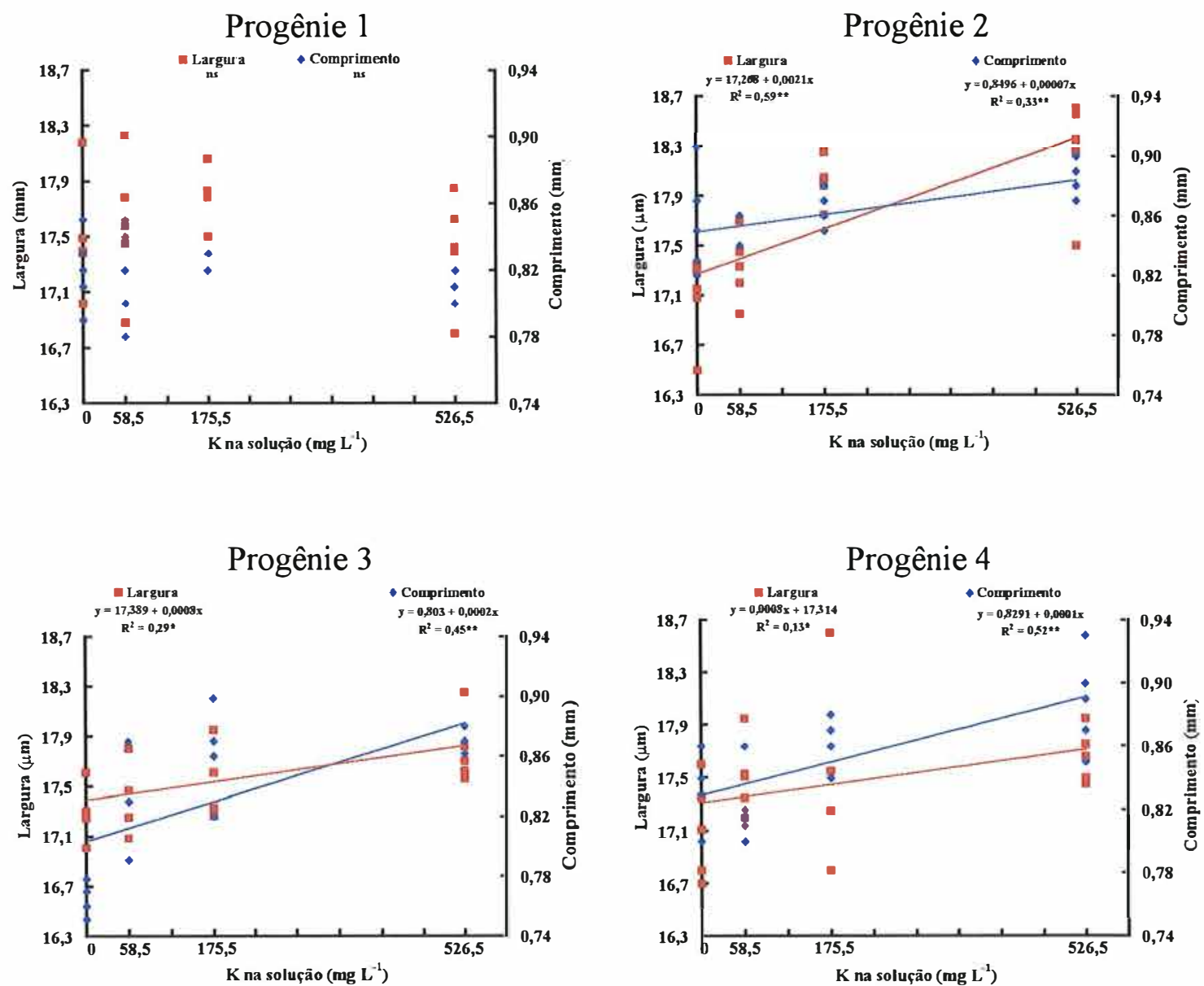

Figura 38. Comprimento e largura das fibras das progênies de Eucalyptus grandis em função das doses de potássio na solução nutritiva. 


\subsubsection{Efeito da concentração de potássio e dos macronutrientes nas folhas diagnóstico e no lenho}

Para as progênies 2, 3 e 4, verificou-se que fibras mais longas foram obtidas com o aumento das concentrações de $\mathrm{K}$ nas folhas diagnóstico (Figura 39). As células do lenho das plantas deficientes em $\mathrm{K}$ podem apresentar menor potencial osmótico interno, que por sua vez, diminui a sua capacidade de extensibilidade, resultando consequentemente em menor largura e comprimento das fibras.
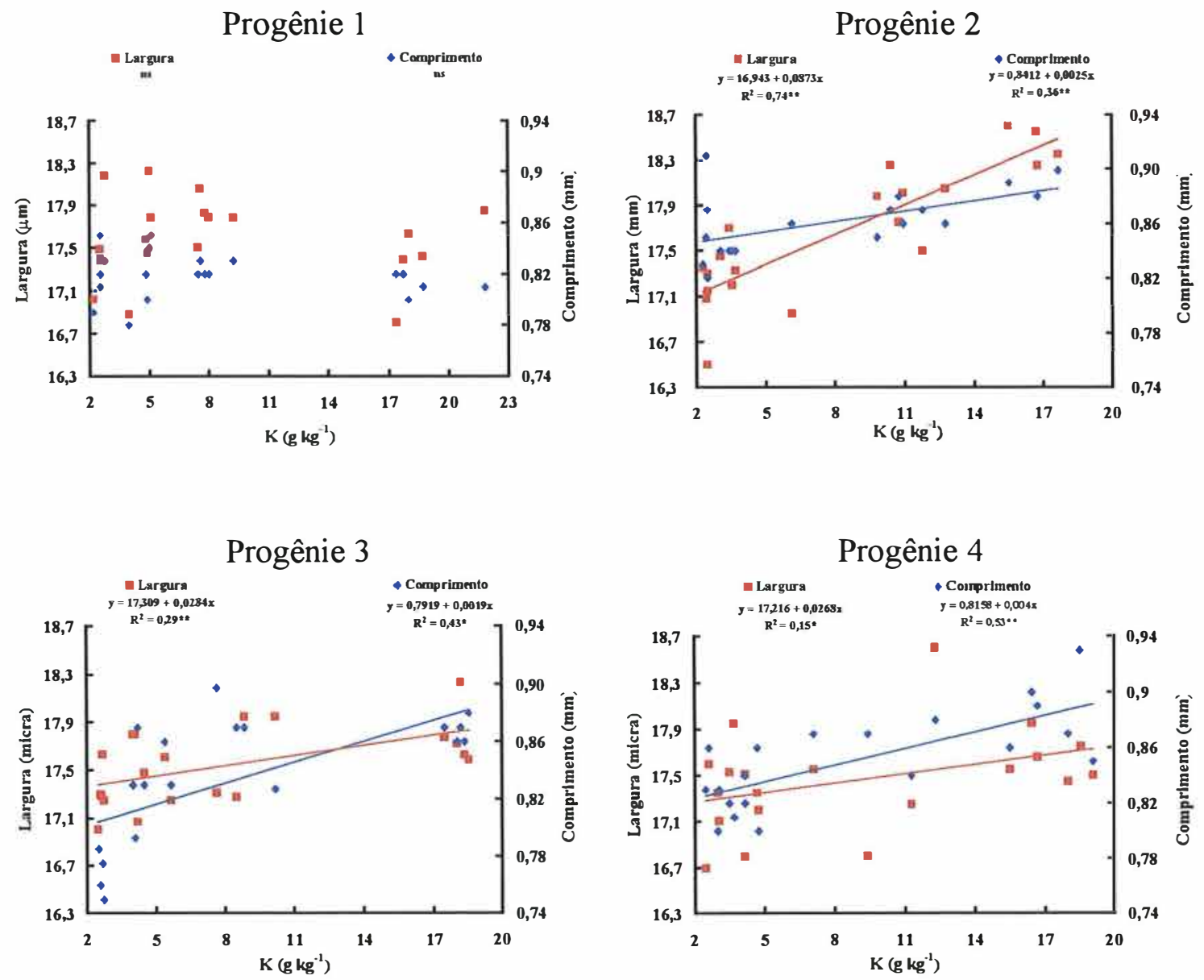

Figura 39. Comprimento e largura das fibras das progênies de Eucalyptus grandis em função da concentração de potássio nas folhas diagnóstico. 
Foram determinadas correlações entre as concentrações dos macronutrientes nas folhas diagnóstico e no lenho e o comprimento e a larguras das fibras (Tabela 39). De maneira geral, aumentos nas concentrações de $\mathrm{N}, \mathrm{Ca}, \mathrm{Mg}$ e $\mathrm{S}$ estavam relacionados a decréscimos no comprimento e na largura das fibras. Esses efeitos foram consequência da menor absorção desses nutrientes a medida que se aumentava o fornecimento de potássio na solução.

$\mathrm{O}$ aumento do fornecimento de $\mathrm{N}$ provocou decréscimos no comprimento das fibras de Pinus elliotti (Malavolta et al., 1966), enquanto que a aplicação combinada de $\mathrm{N}$ e $\mathrm{K}$ promoveram aumentos no comprimento das fibras de Gmelina arborea (Ogbonnaya, 1994). Decréscimos no comprimento das fibras de $E$. grandis foram encontrados por Mello (1968) e Andrade et al. (1994) com o aumento do fornecimento de Ca através da calagem. A aplicação de NPS em Pinus contorta também reduziu o comprimento dos traqueídeos. No entanto, na maior parte desses trabalhos, a redução no comprimento das fibras estava relacionada ao maior ritmo de crescimento das árvores, proporcionada pela aplicação dos nutrientes. Isto não pode ser aplicado no presente estudo, uma vez que as fibras mais longas foram encontradas em plantas que tiveram o seu crescimento reduzido pela aplicação de potássio, ou seja, na dose mais elevada. Isto mostra que a atuação do $\mathrm{K}$ sobre o comprimento das fibras é mais direta e independe do ritmo de crescimento das plantas.

Tabela 39. Coeficientes de correlações de Pearson entre a concentração dos macronurrientes nas folhas diagnóstico e no lenho com o comprimento e a largura das fibras das progènies de Eucalyptus grandis.

\begin{tabular}{|c|c|c|c|c|c|c|c|c|c|c|c|c|}
\hline \multirow{2}{*}{$\begin{array}{l}\text { Material } \\
\text { genético }\end{array}$} & \multirow{2}{*}{$\begin{array}{l}\mathrm{N} \\
\mathrm{FD}^{l}\end{array}$} & \multirow[b]{2}{*}{$\mathrm{L}^{2}$} & \multicolumn{2}{|c|}{$\bar{P}$} & \multicolumn{2}{|c|}{$\bar{K}$} & \multicolumn{2}{|c|}{$\mathrm{Ca}$} & \multicolumn{2}{|c|}{$\mathrm{Mg}$} & \multicolumn{2}{|c|}{$\bar{S}$} \\
\hline & & & FD & $\mathrm{L}$ & FD & $\mathrm{L}$ & FD & $\mathrm{L}$ & FD & $\mathrm{L}$ & FD & $\mathrm{L}$ \\
\hline & \multicolumn{12}{|c|}{ Comprimento das fibras } \\
\hline Progênie 1 & ns & ns & $\mathrm{ns}$ & $-0,56^{*}$ & ns & ns & ns & ns & ns & $\overline{\mathrm{ns}}$ & ns & ns \\
\hline Progènie 2 & ns & $-0,40 *$ & ns & ns & $0,60 * *$ & $0,44 *$ & ns & ns & ns & $-0,58 * *$ & ns & $-0,5 \mathrm{I} *$ \\
\hline Progènie 3 & ns & $-0,64=$ & ns & ns & $0,65 * *$ & $0,82=*$ & $-0,73=$ & $-0,43=$ & $-0,68=$ & $-0,76 * *$ & $-0,65=$ & $-0,74 *$ \\
\hline Progènie 4 & ns & $-0,6] * *$ & ns & ns & $0,73=*$ & $0,80 * *$ & $-0,52=$ & $-0,61 * *$ & $-0,61 * *$ & $-0,69 * *$ & $-0,51 * *$ & $-0,63 * *$ \\
\hline \multirow[t]{2}{*}{ Todos } & $-0,27 *$ & $-0,52=$ & ns & ns & $0,45 * *$ & $0,44 *$ & $-0,32=$ & $-0,36=$ & $-0,38 *=$ & $-0,62 * *$ & $-0,38 *$ & $-0,44 * \cdots$ \\
\hline & \multicolumn{12}{|c|}{ Largura das fibras } \\
\hline Progènie 1 & ns & ns & ns & $-0,40$ & ns & $\mathrm{ns}$ & ns & ns & $\overline{\mathrm{Ns}}$ & ns & $\overline{\mathrm{ns}}$ & $\overline{\mathrm{ns}}$ \\
\hline Progènie 2 & $-0,54 *$ & ns & ns & $0,42 *$ & $0,86 * *$ & $0,87=$ & $-0,72=$ & ns & $-0,68 * *$ & ns & $-0,73 * *$ & $-0,76=$ \\
\hline Progènie 3 & ns & $-0,70 * *$ & ns & ns & $0,51 *=$ & $0,54=$ & $-0,46=$ & ns & $-0,53 *$ & ns & $-0,61 * *$ & $-0,49=$ \\
\hline Progènie 4 & $-0,70 * *$ & ns & ns & $0,50 *$ & ns & $0,53 *$ & ns & ns & ns & ns & ns & ns \\
\hline Todos & $-0,43=$ & $-0,26=$ & ns & ns & $0,42 * *$ & $0,51 *$ & $-0,43 * *$ & ns & $-0,38=$ & ns & $-0,52 * *$ & $-0,31 *$ \\
\hline
\end{tabular}




\subsection{Efeito das relações $\mathrm{N} / \mathrm{K}, \mathrm{K} / \mathrm{P}, \mathrm{K} / \mathrm{Ca}$ e $\mathrm{K} / \mathrm{Mg}$ nas folhas diagnóstico e no lenho}

Para as progênie 2, 3 e 4, aumentos na relação N/K nas folhas reduziram o comprimento e largura das fibras. O mesmo não foi verificado para a progênie 1 . Com a variação da $\mathrm{N} / \mathrm{K}$ nas folhas de 1 para 8 , o decréscimo no comprimento das fibras foi mais marcante na progênie 3 , sendo de $11,4 \%$, enquanto que para as progênies 2 e 4 foram de 3,6\% e 6,3\%, respectivamente (Figura 40).

Com a variação N/K nas folhas de 1 para 8 , a redução da largura das fibras foi mais pronunciada na progênie $2(7,1 \%)$ quando comparada com as progênies 3 $(2,7 \%)$ e $4(3,4 \%)$, conforme a Figura 40.
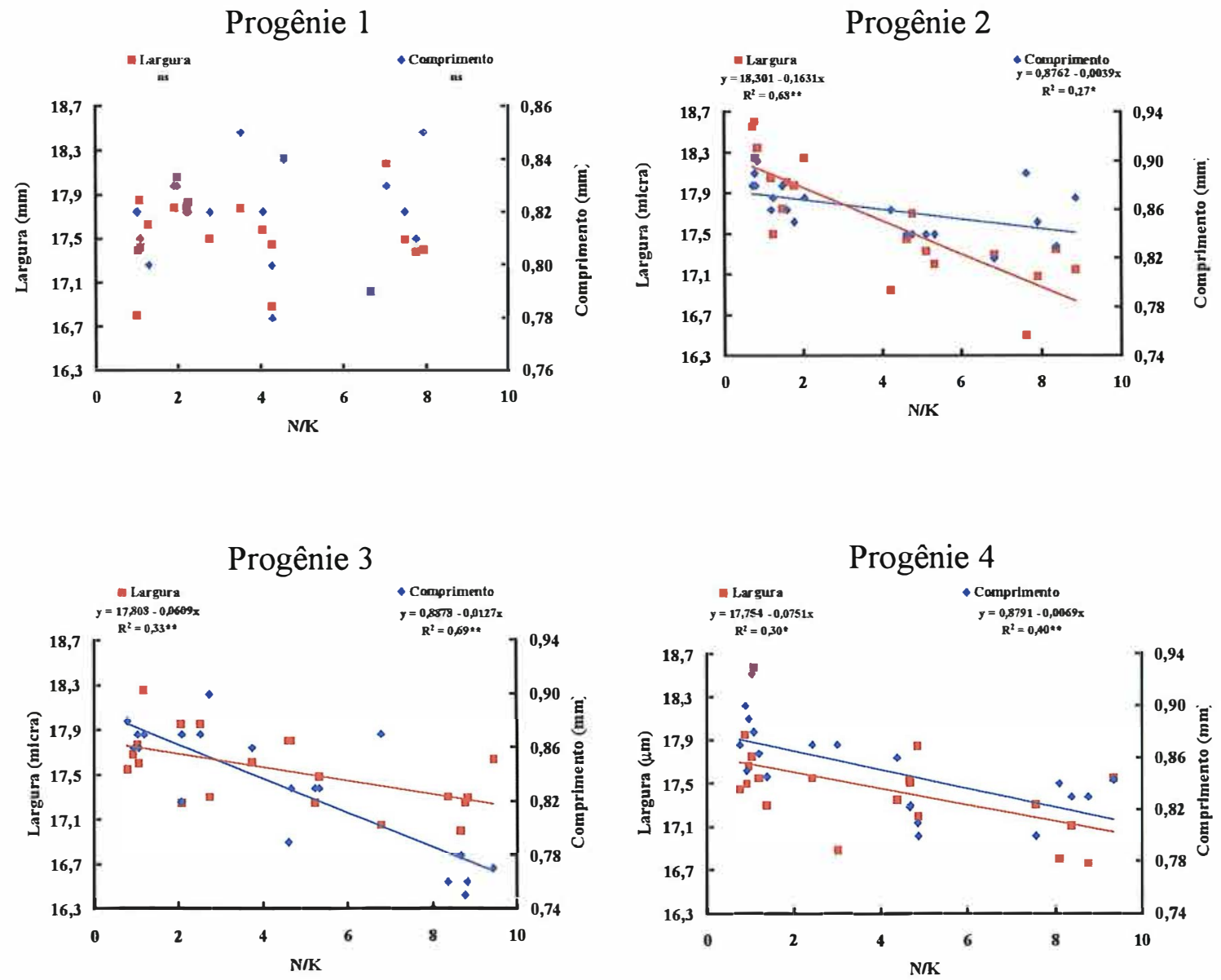

Figura 40. Comprimento e largura das fibras das progênies de Eucalyptus grandis em função da relação N/K nas folhas diagnóstico. 
Não houve efeito da relação K/P nas folhas sobre o comprimento e a largura das fibras na progênie 1. A influência da relação foliar K/P sobre esses parâmetros anatômicos foi semelhante para as progênies 2 e 4, ou seja, fibras mais longas e mais espessas ocorreram com o aumento dessa relação. Para a progênie 3, as fibras mais compridas e largas foram observadas quando a relação $\mathrm{K} / \mathrm{P}$ era de aproximadamente 12 (Figura 41).
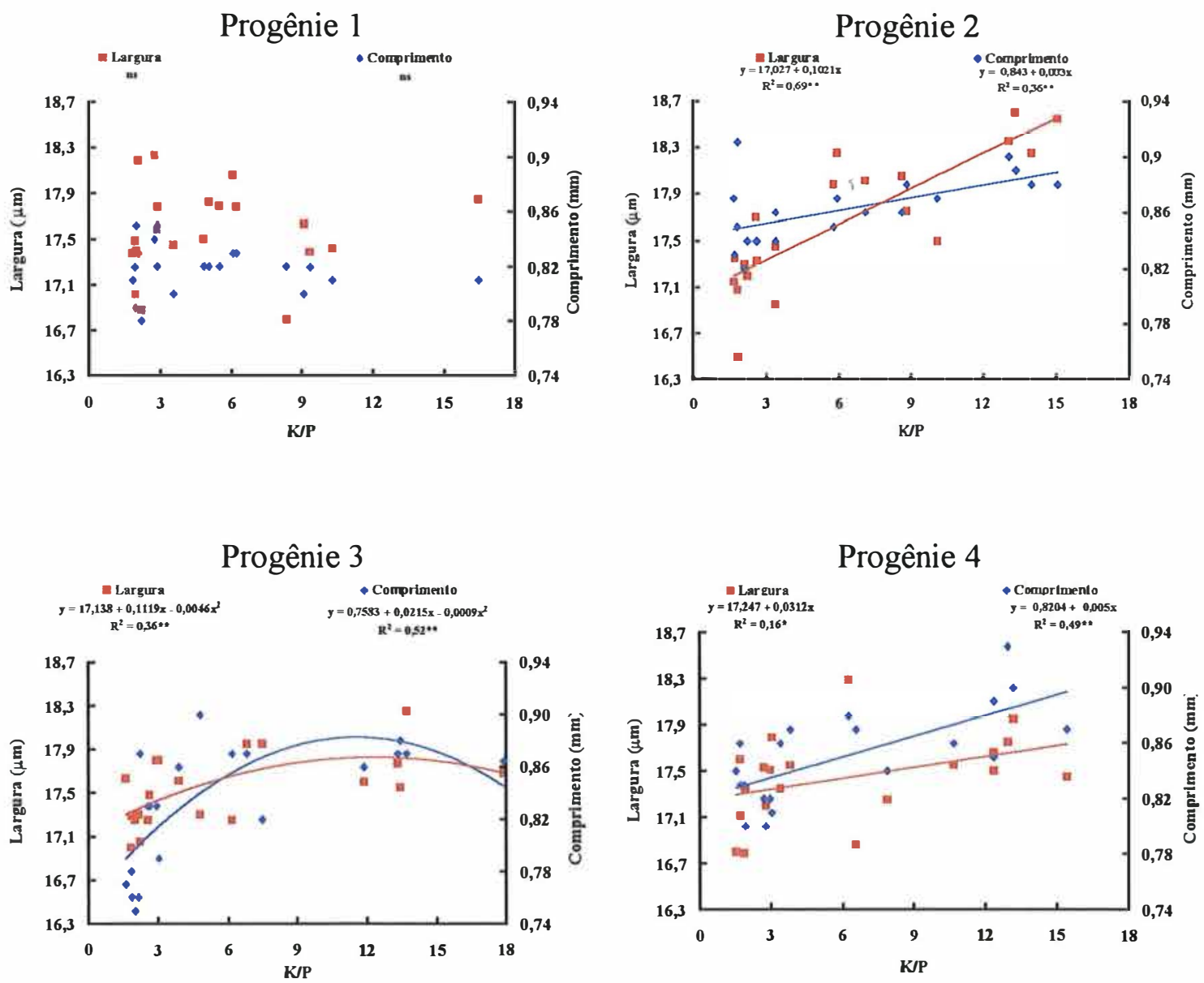

Figura 41. Comprimento e largura das fibras das progênies de Eucalyptus grandis em função da relação $\mathrm{K} / \mathrm{P}$ nas folhas diagnóstico. 
Os resultados obtidos indicaram que fibras mais longas e mais espessas foram encontradas aumentando-se a relação $\mathrm{K} / \mathrm{Ca}$ e $\mathrm{K} / \mathrm{Mg}$ nas folhas diagnóstico, exceto na progênie 1 (Figuras 42 e 43).
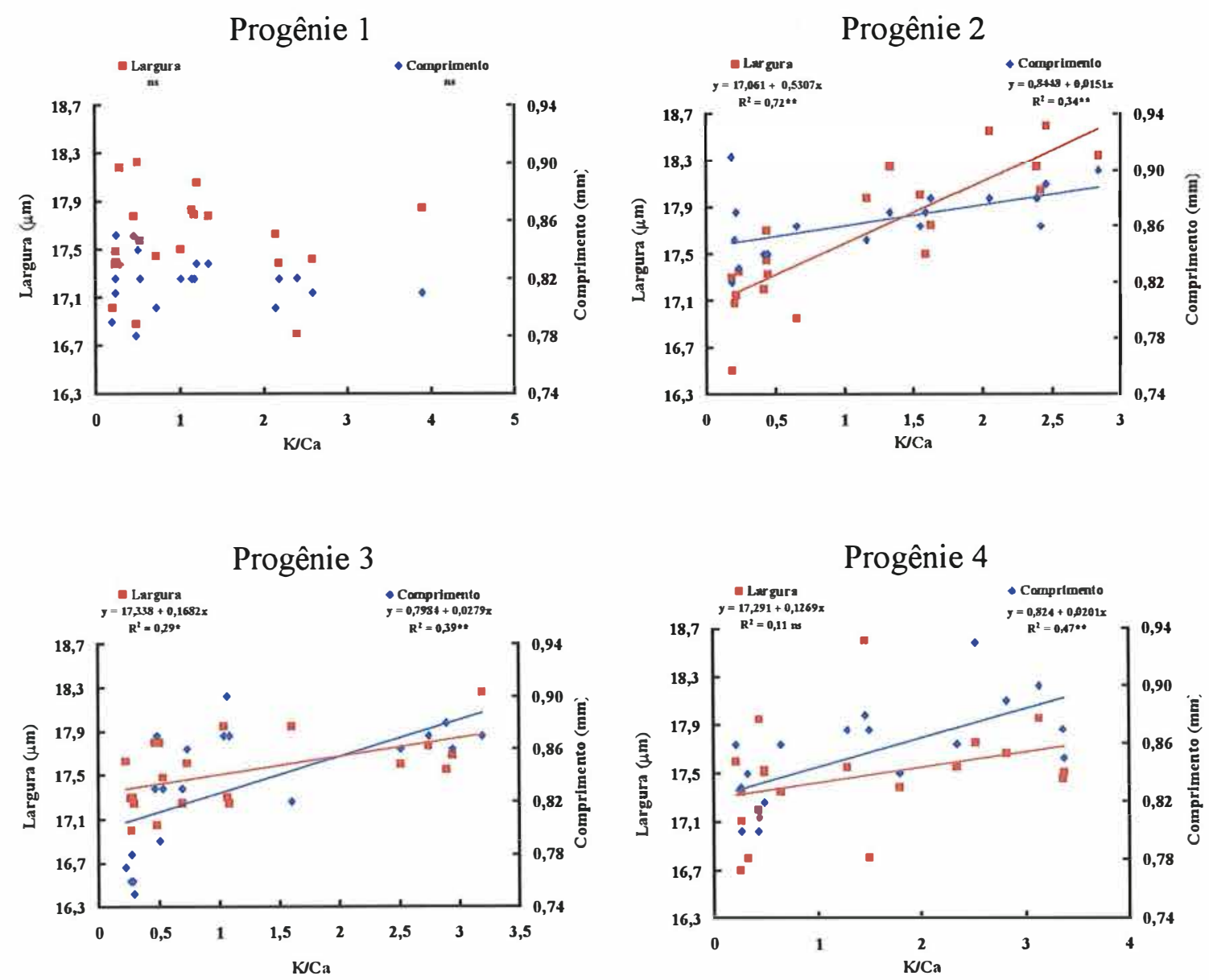

Figura 42. Comprimento e largura das fibras das progênies de Eucalyptus grandis em função da relação $\mathrm{K} / \mathrm{Ca}$ nas folhas diagnóstico. 

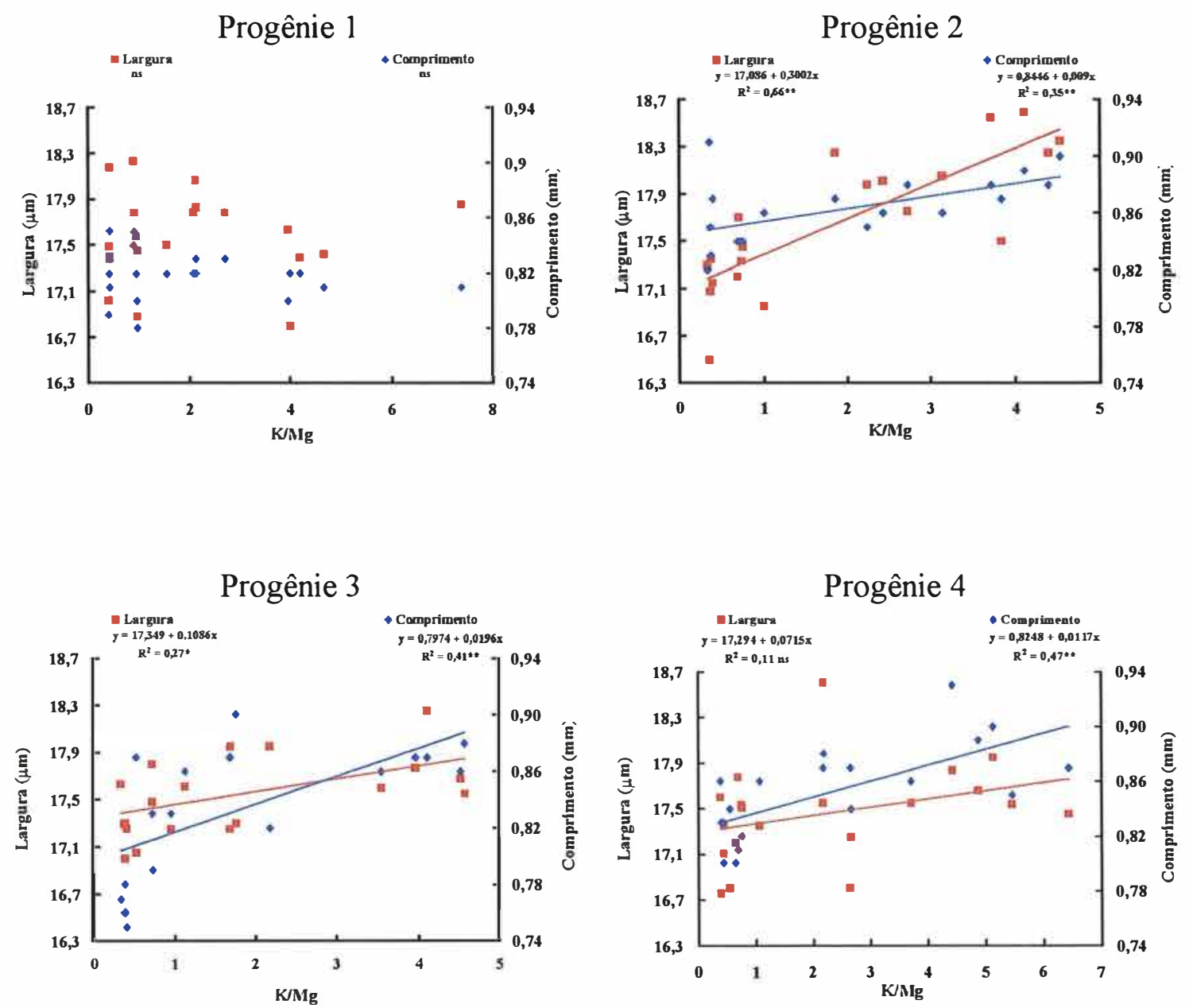

Figura 43. Comprimento e largura das fibras das progênies de Eucalyptus grandis em função da relação $\mathrm{K} / \mathrm{Mg}$ nas folhas diagnóstico.

Os resultados obtidos para o comprimento e a larguras das fibras quando variou-se a relação $\mathrm{N} / \mathrm{K}, \mathrm{K} / \mathrm{P}, \mathrm{K} / \mathrm{Ca}$ e $\mathrm{K} / \mathrm{Mg}$ no lenho foram semelhantes aos constatados para as relações foliares (Tabela 40). 
Tabela 40. Coeficientes de correlações de Pearson entre a relação N/K, K/P, K/Mg, K/Ca e $\mathrm{K} / \mathrm{Ca}+\mathrm{Mg}$ no lenho e o comprimento e a largura das fibras nas progênies de Eucalyptus grandis.

\begin{tabular}{lccccc}
\hline \hline Material genético & $\mathrm{N} / \mathrm{K}$ & $\mathrm{K} / \mathrm{P}$ & $\mathrm{K} / \mathrm{Mg}$ & $\mathrm{K} / \mathrm{Ca}$ & $\mathrm{K} / \mathrm{Ca}+\mathrm{Mg}$ \\
\cline { 2 - 6 } & \multicolumn{5}{c}{ Comprimento das fibras } \\
\hline Progênie 1 & $\mathrm{ns}$ & $\mathrm{ns}$ & $\mathrm{ns}$ & $\mathrm{ns}$ & $\mathrm{ns}$ \\
Progênie 2 & $-0,50^{*}$ & $\mathrm{~ns}$ & $0,46^{*}$ & $0,48^{*}$ & $\mathrm{~ns}$ \\
Progênie 3 & $-0,88^{* *}$ & $0,84^{* *}$ & $0,73^{* *}$ & $0,84^{* *}$ & $0,65^{* *}$ \\
Progênie 4 & $-0,58^{* *}$ & $0,74^{* *}$ & $0,80^{* *}$ & $0,86^{* *}$ & $0,77^{* *}$ \\
Todos & $-0,55^{* *}$ & $0,38^{* *}$ & $0,52^{* *}$ & $0,55^{* *}$ & $0,46^{*}$ \\
\hline & & & Largura das fibras & $\mathrm{ns}$ \\
\hline Progênie 1 & $\mathrm{ns}$ & $\mathrm{ns}$ & $\mathrm{ns}$ & $\mathrm{ns}$ & $0,88^{* *}$ \\
Progênie 2 & $-0,81^{* *}$ & $0,83^{* *}$ & $0,88^{* *}$ & $0,85^{* *}$ & $0,52^{*}$ \\
Progênie 3 & $-0,58^{* *}$ & $0,50^{*}$ & $0,52^{*}$ & $0,49^{*}$ & $0,50^{*}$ \\
Progênie 4 & $-0,48^{* *}$ & $0,43^{*}$ & $0,51^{*}$ & $0,57^{* *}$ & $0,50^{* *}$ \\
Todos & $-0,51^{* *}$ & $0,43^{*}$ & $0,50^{* *}$ & $0,49^{* *}$ & \\
\hline \hline
\end{tabular}

${ }^{* *}$ - significativo a $1 \%$ de probabilidade; ${ }^{*}$ - significativo; ns - não significativo.

\subsubsection{Diâmetro do lume, espessura e fração parede}

\subsection{Efeito das progênies e das doses de potássio}

Ao contrário do comprimento e largura das fibras, não houve interação entre as doses de $\mathrm{K}$ e as progênies para o diâmetro do lume, espessura e fração parede das fibras. Houve diferença significativa entre os materiais genéticos para a espessura e a fração parede, sendo que, os valores encontrados na progênie 3 foram menores quando comparados as demais (Figura 44). As progênies não diferiram em relação ao diâmetro do lume das fibras. 
Espessura da parede

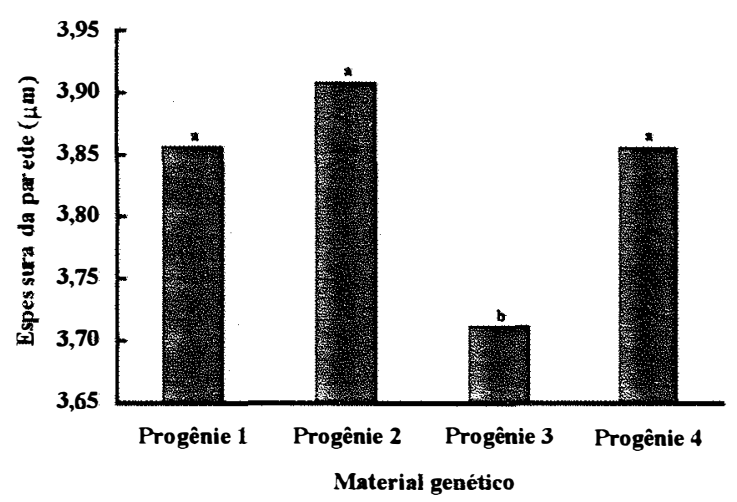

Fração parede

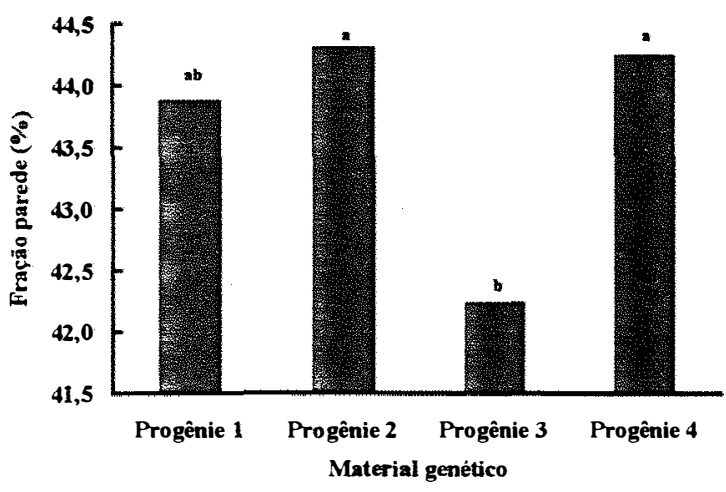

Figura 44. Espessura da parede celular e fração parede das fibras das progênies de Eucalyptus grandis.

Houve efeito das doses de potássio sobre a espessura da parede e o diâmetro do lume das fibras, independente das progênies (Figura 45). Com aumento das doses de potássio foi constatado incrementos no diâmetro do lume em até $7,3 \%$ ao comparar a testemunha com a dose de $526,5 \mathrm{mg} \mathrm{L}^{-1}$. Para a espessura da parede, verificou-se diferença apenas entre a dose de 175,5 e a de $526,5 \mathrm{mg} \mathrm{L}^{-1}$, sendo que as fibras com paredes mais espessas ocorreram na primeira dose.

Espessura da parede

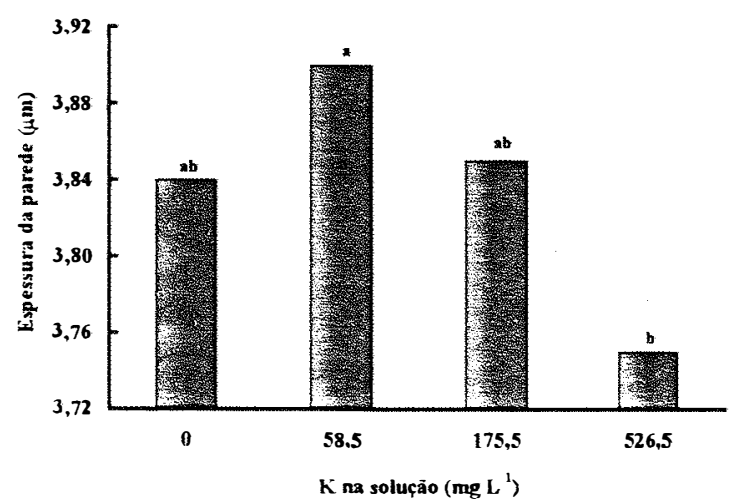

Diâmetro do lume

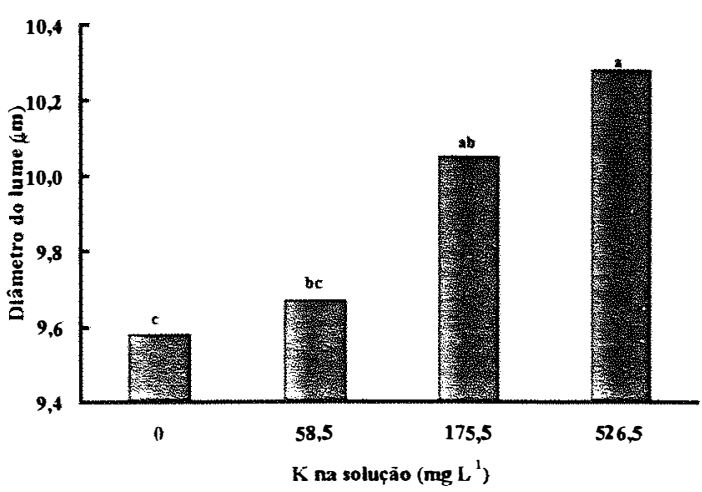

Figura 45. Espessura da parede celular e do diâmetro do lume das fibras em função das doses de potássio na solução nutritiva. 
O comportamento do diâmetro do lume e da espessura da parede celular das fibras das progênies, em função das doses de $\mathrm{K}$, está apresentado na Figura 46. Os efeitos das doses de $\mathrm{K}$ sobre o diâmetro do lume foram mais marcantes nas progênies $2 \mathrm{e}$ 3, enquanto que para a espessura da parede na progênie 1. Em ambos os casos, adição de K na solução proporcionou aumento no diâmetro do lume e consequentemente redução na espessura da parede celular. Resultados semelhantes foram encontrados em Picea abies (Cutter \& Murphy, 1978). No entanto, Gray \& Zeeuv (1975) verificaram que o suprimento de potássio reduzia tanto a espessura como o diâmetro dos traqueídeos da madeira adulta de Pinus resinosa, com efeitos opostos na madeira juvenil. Em Pinus elliotti juvenil, Malavolta et al. (1966) não verificaram qualquer efeito do K sobre esses parâmetros anatômicos.

A redução da espessura da parede encontrada na alta dose de potássio pode ser resultado da menor absorção de $\mathrm{Ca}$, uma vez que altas concentrações de $\mathrm{K}$ no meio, inibem a absorção de $\mathrm{Ca}$. As evidências do efeito indireto do $\mathrm{Ca}$ no presente estudo, podem ser ressaltadas pelo trabalho de Dunisch et al. (1998), os quais verificaram que a maior síntese de parede celular, bem como, da lignificação dos traqueídeos de Picea abies ocorria na presença de maior conteúdo de $\mathrm{Ca}$ nos tecidos. Eklund \& Eliason (1990) também constataram que a maior presença de Ca, proporcionou maior deposição de lignina na parede das fibras. Resultados concordantes também foram verificados por Sgarbi et al. (1999), que encontraram redução do teor de lignina na madeira de $E$. grandis $\mathrm{x}$ E. urophylla quando as plantas foram submetidas a deficiência de $\mathrm{Ca}$.

Poucos estudos foram realizados sobre o efeito do $\mathrm{K}$ nas características anatômicas da madeira. A maioria relacionou os efeitos do nitrogênio sobre esses parâmetros. Os efeitos provocados pela adição de $\mathrm{N}$ sobre a espessura da parede são na maioria das vezes negativos (Malavolta et al., 1966; Weetman, 1971 e Brix \& Mitchell, 1980). Portanto, estudos devem ser realizados procurando avaliar a interação $\mathrm{N} \times \mathrm{K}$ sobre as características anatômicas. 

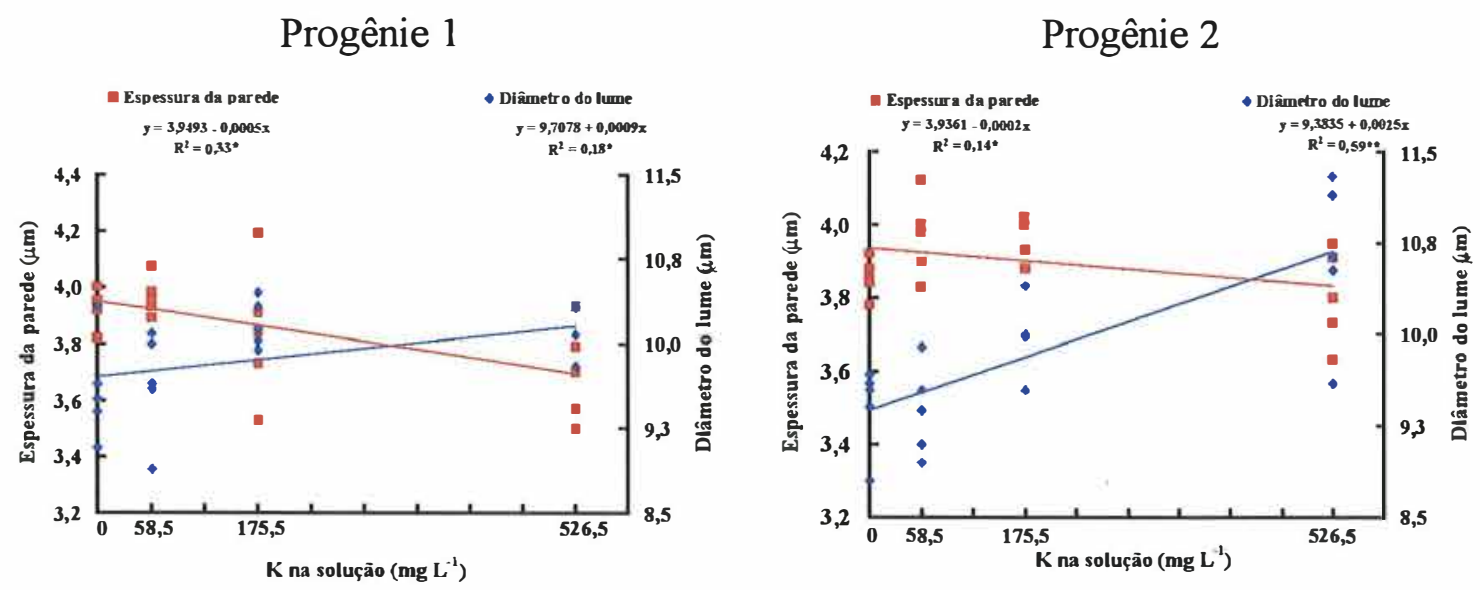

Progênie 3
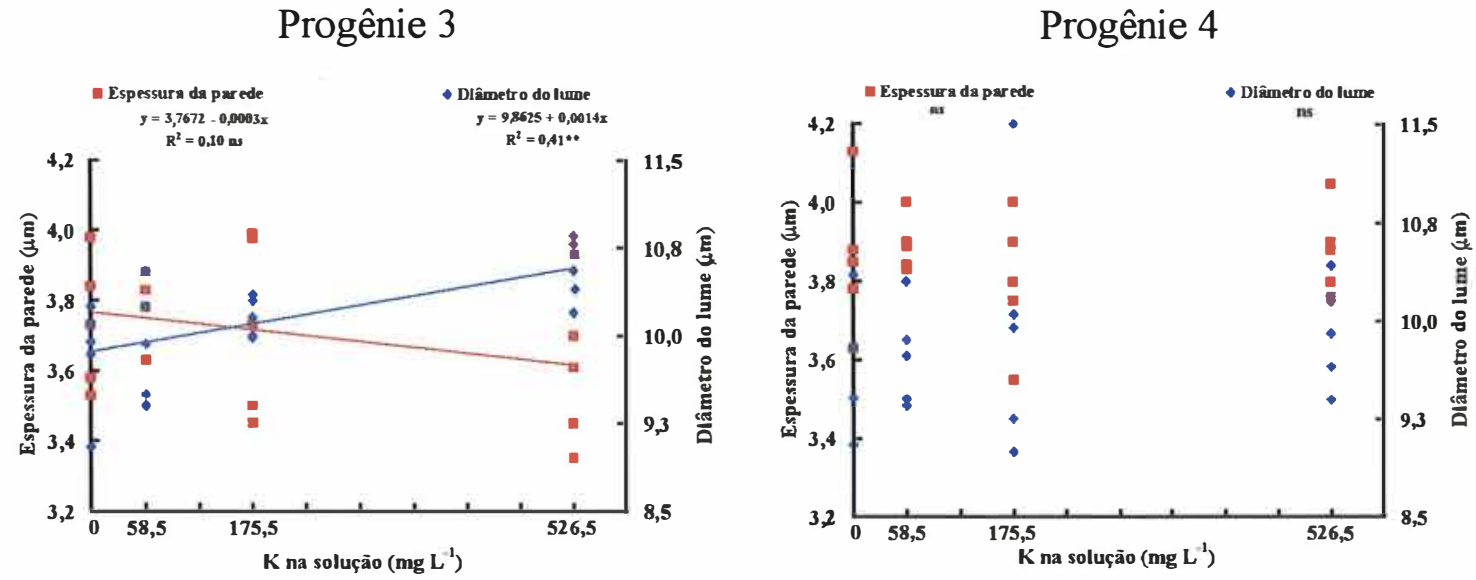

Figura 46. Espessura da parede celular e do diâmetro do lume das fibras das progênies de Eucalyptus grandis em função das doses de potássio na solução nutritiva.

A Figura 47 mostra a fração parede das fibras das diferentes progênies em função das doses de $\mathrm{K}$ na solução. Com exceção feita à progênie 4, todas as outras apresentaram decréscimos da fração parede com o aumento das doses de potássio. 


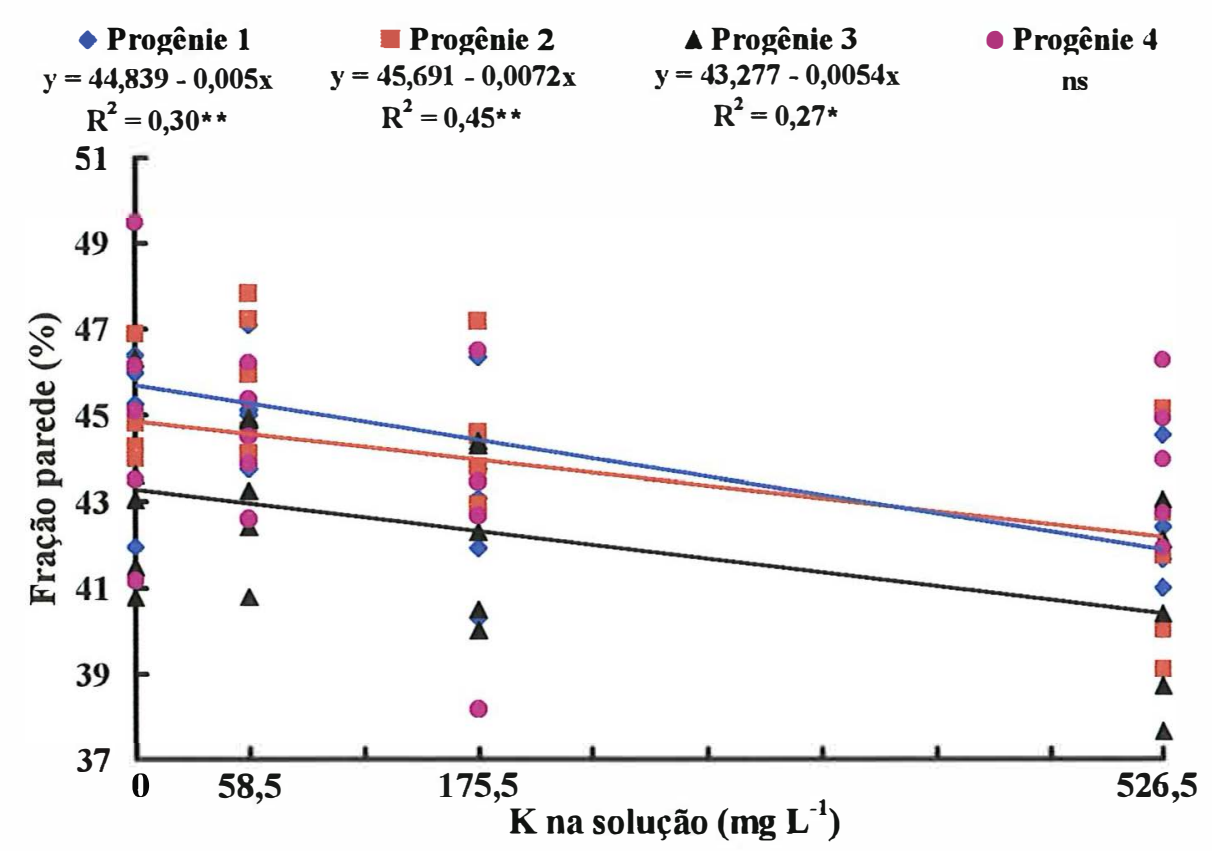

Figura 47. Fração parede das fibras das progênies de Eucalyptus grandis em função das doses de potássio na solução nutritiva.

\subsection{Efeito da concentração de potássio e dos macronutrientes nas}

\section{folhas diagnóstico e no lenho}

Foram determinados os coeficientes de correlações de Pearson entre o diâmetro do lume, espessura e fração parede das fibras e as concentrações dos macronutrientes nas folhas diagnóstico e no lenho (Tabela 41). Para todas as progênies, verificaram-se correlações positivas entre a concentração de $\mathrm{K}$ no lenho e o diâmetro do lume das fibras. No entanto, quando analisou-se as folhas, as correlações foram significativas somente nas progênies 2 e 3 . Os efeitos dos nutrientes foram mais relevantes para o diâmetro do lume quando comparado a espessura da parede. Algumas correlações que se destacaram foram: diâmetro do lume $\mathrm{x} \mathrm{N}$ nas folhas para a progênie 3 $(r=-0,76)$; diâmetro do lume $x \mathrm{~N}$ no lenho para a progênie $3(r=-0,67)$; diâmetro do lume $x \mathrm{~K}$ nas folhas para a progênie $2(r=0,79)$ e para a progênie $3(r=0,61)$; diâmetro do lume $x \mathrm{~K}$ no lenho para a progênie $2(\mathrm{r}=0,74)$ e para a progênie $3(\mathrm{r}=0,61)$; 
diâmetro do lume $\mathrm{x} \mathrm{Mg}$ nas folhas para a progênie $3(\mathrm{r}=-0,66)$; diâmetro do lume $\mathrm{x} \mathrm{Mg}$ no lenho para a progênie $1(\mathrm{r}=-0,71)$; diâmetro do lume $\mathrm{x}$ nas folhas para a progênie 2 $(r=-0,66)$. Para e espessura da parede celular, verificou-se que as plantas da progênie 1 , com maiores concentrações de $\mathrm{Mg}$ no lenho, apresentavam fibras com paredes mais espessas $(r=0,70)$. Outra correlação de destaque foi entre a espessura da parede e a concentração de $\mathrm{P}$ no lenho da progênie 3 , uma vez que maiores concentrações proporcionaram fibras de parede menos espessas $(r=-0,78)$.

A medida que se aumentou a concentração de $\mathrm{K}$ nas folhas diagnóstico ocorreu redução da fração parede das progênies 1,2 e 3 (Figura 48). Quando as concentrações de potássio nas folhas variaram de 2 a $15 \mathrm{~g} \mathrm{~kg}^{-1}$, as reduções foram de: $4,8 \%$ na progênie $1,7,1 \%$ na progênie 2 e $5,5 \%$ na progênie 3 .

Tabela 41. Coeficientes de correlações de Pearson entre a concentração dos macronutrientes nas folhas diagnóstico e no lenho e o diâmetro do lume, espessura e fração parede das fibras das progênies de Eucalyptus grandis.

\begin{tabular}{|c|c|c|c|c|c|c|c|c|c|c|c|c|}
\hline \multirow{2}{*}{$\begin{array}{l}\text { Material } \\
\text { genético }\end{array}$} & \multicolumn{2}{|c|}{$N$} & \multicolumn{2}{|c|}{$\mathrm{P}$} & \multicolumn{2}{|c|}{$\mathrm{K}$} & \multicolumn{2}{|c|}{$\mathrm{Ca}$} & \multicolumn{2}{|c|}{$\mathrm{Mg}$} & \multicolumn{2}{|c|}{$S$} \\
\hline & $\mathrm{FD}^{1}$ & $\mathrm{~L}^{2}$ & FD & $\mathrm{L}$ & FD & $\mathrm{L}$ & FD & $\mathrm{L}$ & FD & $\mathrm{L}$ & FD & $\mathrm{L}$ \\
\hline & \multicolumn{12}{|c|}{ Diâmetro do lume } \\
\hline Progênie 1 & ns & ns & ns & $-0,56 *=$ & ns & 0,48 & ns & ns & ns & $-0,71 * *$ & $-0,42 *$ & $-0,44 * *$ \\
\hline Progênie 2 & $-0,50$ & Ns & ns & $0,40 *$ & $0,79 * *$ & $0,74 * \cdot$ & $-0,48$ & ns & $-0,49 *$ & $-0,41 *$ & $-0,54 *$ & $-0,66 * \cdot$ \\
\hline Progênie 3 & $-0,76 \cdots$ & $-0,67 * \cdot$ & $-0,56$ & ns & $0,61 * *$ & $0,61 *$ & $-0,50$ & ns & $-0,66 *$ & ns & $-0,59 * *$ & $-0,50$ \\
\hline Progênie 4 & $-0,52=$ & ns & ns & $0,66 * *$ & ns & $0,44 *$ & ns & ns & ns & ns & ns & ns \\
\hline \multirow[t]{2}{*}{ Todos } & $-0,36 \cdots$ & $-0,24=$ & ns & 0,27 * & $0,48 * *$ & $0,53 * *$ & $-0,34 *$ & ns & $-0,30 *$ & $-0,27 *$ & $-0,42 * *$ & $-0,38 * *$ \\
\hline & \multicolumn{12}{|c|}{ Espessura da parede } \\
\hline Progênie 1 & ns & ns & ns & ns & $-0,54 * *$ & $-0,46 *$ & ns & $\overline{\mathrm{ns}}$ & ns & $0,70 * *$ & $0,45 *$ & $0,65 * *$ \\
\hline Progênie 2 & ns & & ns & ns & ns & ns & ns & ns & ns & ns & ns & Ns \\
\hline Progênie 3 & & ns & ns & $-0,40 *$ & ns & ns & ns & ns & ns & ns & ns & ns \\
\hline Progênie 4 & ns & ns & ns & $-0,78 * *$ & ns & ns & ns & ns & ns & ns & ns & ns \\
\hline \multirow[t]{2}{*}{ Todos } & ns & ns & ns & $-0,22 *$ & ns & $-0,23=$ & ns & ns & ns & ns & ns & $0,22=$ \\
\hline & \multicolumn{12}{|c|}{ Fração parede } \\
\hline Progênie I & ns & ns & ns & $0,46^{*}$ & $-0,55 *=$ & $-0,55=$ & ns & ns & ns & $0,81 * *$ & $0, \overline{45 *}$ & $0,63 * *$ \\
\hline Progênie 2 & ns & ns & ns & ns & $-0,63 *$ & $-0,54 \cdots$ & ns & ns & ns & ns & ns & $0,49=$ \\
\hline Progênie 3 & $0,72 *$ & $0,45=$ & 0,47 & $-0,42$ & $-0,54 *$ & $-0,46$ & ns & ns & $0,39=$ & $0,53=$ & $0,40 *$ & ns \\
\hline Progênie 4 & ns & ns & ns & $-0,72 *$ & ns & ns & ns & ns & ns & ns & ns & ns \\
\hline Todos & ns & ns & ns & $-0,27 *$ & $-0,40 * *$ & $-0,43$ & ns & ns & ns & $0,26 *$ & $0,30 *$ & $0,34 * *$ \\
\hline
\end{tabular}

1 - folha diagnóstico: 2 - lenho: ${ }^{* *}$ - significativo a $1 \%$ de probabilidade: ${ }^{*}$ - significativo a $5 \%$ de probabilidade; ns - não significativo. 
Progênie 1

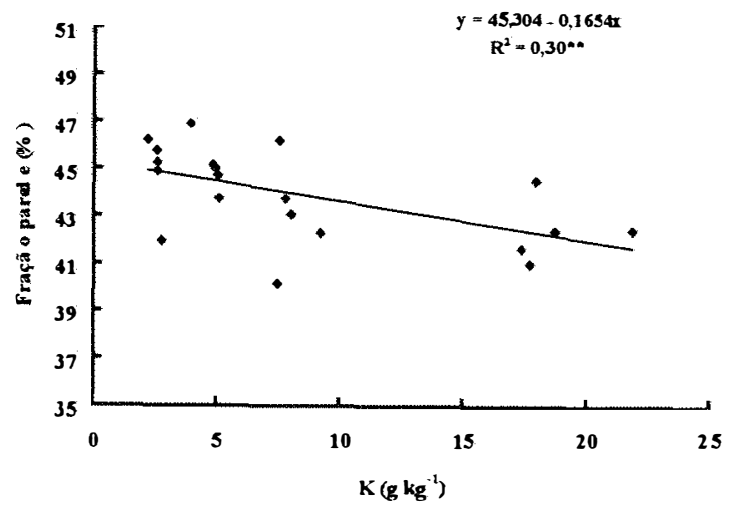

Progênie 3

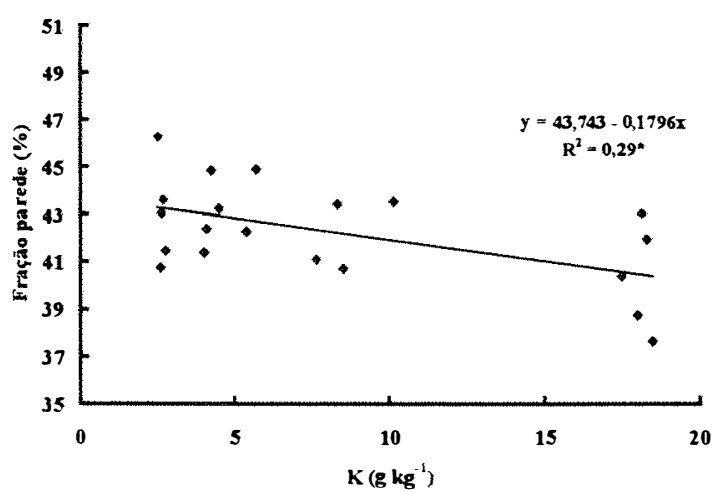

Progênie 2

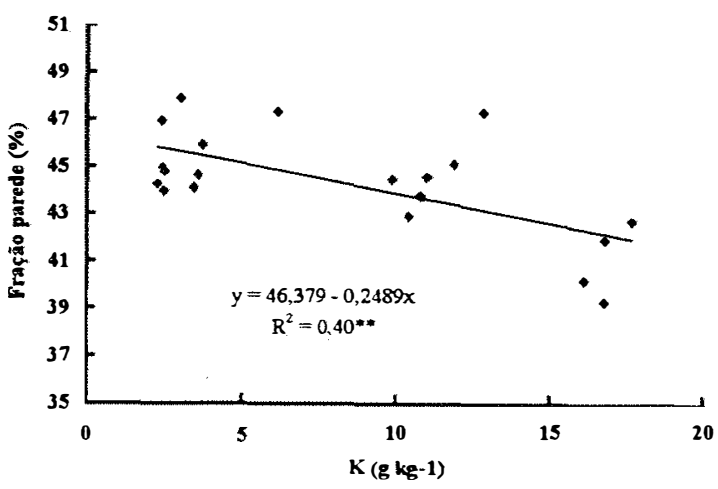

Progênie 4

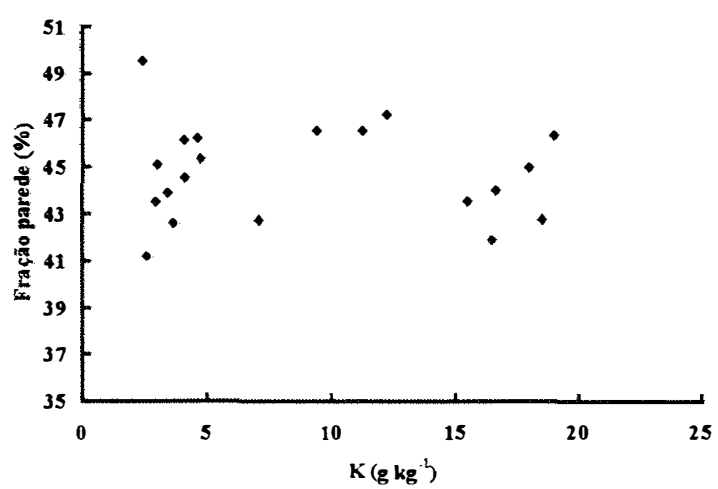

Figura 48. Fração parede das fibras das progênies de Eucalyptus grandis em função das doses de potássio na solução nutritiva.

\subsection{Efeito das relações $\mathrm{N} / \mathrm{K}, \mathrm{K} / \mathrm{P}, \mathrm{K} / \mathrm{Mg}, \mathrm{K} / \mathrm{Ca}$ e $\mathrm{K} / \mathrm{Ca}+\mathrm{Mg}$ nas folhas diagnóstico e no lenho}

Foram determinados os coeficientes de correlações de Pearson entre o diâmetro do lume, espessura e fração parede das fibras e a razão $\mathrm{N} / \mathrm{K}, \mathrm{K} / \mathrm{P}, \mathrm{K} / \mathrm{Mg}, \mathrm{K} / \mathrm{Ca}$ e $\mathrm{K} / \mathrm{Ca}+\mathrm{Mg}$ nas folhas diagnóstico e no lenho (Tabela 42). As correlações entre a razão $\mathrm{K} / \mathrm{Ca}$ e $\mathrm{K} / \mathrm{Mg}$ no lenho e o diâmetro do lume foram significativas para todos os materiais genéticos, com destaque para as progênies 2 e 3 . Os aumentos nas razões $\mathrm{K} / \mathrm{P}, \mathrm{K} / \mathrm{Ca}$, 
$\mathrm{K} / \mathrm{Mg}$ e $\mathrm{K} / \mathrm{Ca}+\mathrm{Mg}$, tanto nas folhas como no lenho, resultaram em aumentos no diâmetro do lume, sendo os efeitos opostos para a relação $\mathrm{N} / \mathrm{K}$. A progênie 1 foi a única que teve a espessura da parede das fibras afetada conforme variou-se as relações $N / K$, $\mathrm{K} / \mathrm{P}, \mathrm{K} / \mathrm{Ca}, \mathrm{K} / \mathrm{Mg}$ e $\mathrm{K} / \mathrm{Ca}+\mathrm{Mg}$. Os efeitos foram mais consistentes para a relação $\mathrm{K} / \mathrm{Mg}$ no lenho, uma vez que aumentos na razão $\mathrm{K} / \mathrm{Mg}$ reduziram a espessura da parede celular.

Tabela 42. Coeficientes de correlações de Pearson entre a razão N/K, K/P, K/Ca, K/Mg e $\mathrm{K} / \mathrm{Ca}+\mathrm{Mg}$ nas folhas diagnóstico e no lenho e o diâmetro do lume, espessura e fração parede das fibras das progênies de Eucalyptus grandis.

\begin{tabular}{|c|c|c|c|c|c|c|c|c|c|c|}
\hline \multirow{2}{*}{$\begin{array}{l}\text { Material } \\
\text { genético }\end{array}$} & \multicolumn{2}{|c|}{$\mathrm{N} / \mathrm{K}$} & \multicolumn{2}{|c|}{$\mathrm{K} / \mathrm{P}$} & \multicolumn{2}{|c|}{$\mathrm{K} / \mathrm{Ca}$} & \multicolumn{2}{|c|}{$\mathrm{K} / \mathrm{Mg}$} & \multicolumn{2}{|c|}{$\mathrm{K} / \mathrm{Ca}+\mathrm{Mg}$} \\
\hline & $\mathrm{FD}^{1}$ & $\mathrm{~L}^{2}$ & FD & $\mathrm{L}$ & FD & $\mathrm{L}$ & FD & $\mathrm{L}$ & FD & $\mathrm{L}$ \\
\hline & & \multicolumn{9}{|c|}{ Diâmetro do lume } \\
\hline Progênie 1 & $-0,43^{* *}$ & $-0,63 *$ & $0,43 *$ & $0,48 *$ & ns & $0,50 *$ & ns & $0,54 *$ & ns & $0,44^{*}$ \\
\hline Progênie 2 & $-0,65 * *$ & $-0,70 * *$ & $0,81^{* *}$ & $0,67 * *$ & $0,73 * *$ & $0,73 * *$ & $0,74 * *$ & $0,78 * *$ & $0,74 * *$ & $0,72 * *$ \\
\hline Progênie 3 & $-0,63 * *$ & $-0,57 *$ & $0,66 * *$ & $0,84^{* *}$ & $0,62 * *$ & $0,72 * *$ & $0,65 * *$ & $0,84 * *$ & $0,63 * *$ & $0,66 * *$ \\
\hline Progênie 4 & ns & ns & ns & ns & ns & $0,42 *$ & ns & $0,48^{*}$ & ns & $0,50 * *$ \\
\hline Todos & $-0,47 * *$ & $-0.47 * *$ & $0.50 * *$ & $0.43^{* *}$ & $0,43 * *$ & $0,53 * *$ & $0.41^{* *}$ & $0.57 * *$ & $0,42 * *$ & $0,53^{* *}$ \\
\hline \multicolumn{11}{|c|}{ Espessura da parede } \\
\hline Progênie 1 & $0,44^{*}$ & $0,53^{*}$ & $-0,44^{*}$ & $-0,44 *$ & $-0.48 *$ & $-0,52 *$ & $-0,47^{*}$ & $-0,59^{*}$ & $-0,48^{*}$ & $-0,47^{*}$ \\
\hline Progênie 2 & ns & ns & ns & ns & ns & ns & ns & ns & ns & ns \\
\hline Progênie 3 & ns & ns & ns & ns & ns & ns & ns & ns & ns & ns \\
\hline Progênie 4 & ns & ns & ns & ns & ns & ns & ns & ns & ns & ns \\
\hline Todos & ns & ns & $-0.25 *$ & ns & ns & $-0.24 *$ & ns & $-0.30 *$ & ns & $-0,23 *$ \\
\hline Progênie 1 & $0,51 *$ & $0,67 *$ & $-0,51^{*}$ & $-0,54 * *$ & $-0.51 *$ & $0,60^{* *}$ & $-0,50 *$ & $-0.66^{* *}$ & $-0,51 *$ & $0,54 * *$ \\
\hline Progênie 2 & $0,42 *$ & $0,52 *$ & $-0,68 * *$ & $-0,47 *$ & $-0.54 *$ & $-0,51^{*}$ & $-0,58 * *$ & $-0,63 * *$ & $-0,56 * *$ & $-0,49 *$ \\
\hline Progênie 3 & $0,46^{*}$ & ns & $-0,47 *$ & $-0,53^{*}$ & $-0,51^{*}$ & $-0,47 *$ & $-0,63 * *$ & $-0,54 *$ & $-0,49 *$ & $-0,50^{*}$ \\
\hline Progênie 4 & ns & ns & ns & ns & ns & ns & ns & $-0,41^{*}$ & ns & ns \\
\hline Todos & $0.34 *$ & $0.35 *$ & $-0.41 * *$ & $-0,34 * *$ & $-0.35 * *$ & $-0.45 * *$ & $-0.33^{* *}$ & $-0,49 * *$ & $-0.35 * *$ & $-0,44 * *$ \\
\hline
\end{tabular}

1 - folha diagnostico: 2 - lenho; ${ }^{* *}$ - significativo a $1 \%$ de probabilidade; * - significativo a $5 \%$ de probabilidade; ns - não significativo.

\subsubsection{Parâmetros químicos}

\subsubsection{Efeito das progênies e das doses de potássio}

Os resultados obtidos para a composição química do lenho em função das doses de potássio são apresentados na Tabela 43. Houve interação entre as doses de K e as progênies para todos os parâmetros químicos analisados. Para a concentração de holocelulose no lenho, ocorreram diferenças entre os materiais genéticos em todas as 
doses de potássio. Ao comparar os genótipos na ausência e na dose de $58,5 \mathrm{mg} \mathrm{L}^{-1}$, constatou-se que as progênies 1 e 2 apresentavam menores concentrações de holocelulose em relação as progênies 3 e 4 . Mas a dose de 175,5 mg de $\mathrm{K} \mathrm{L}^{-1}$, promoveu incrementos na concentração de holocelulose na progênie 2 , fazendo com que juntamente com a progênie 3 , esses materiais fossem superiores em relação aos outros. $\mathrm{Na}$ dose mais alta de $\mathrm{K}$, a progênie 1 também apresentou menor concentração de holocelulose, diferindo estatisticamente das demais. Independente do genótipo, os resultados mostraram um aumento da concentração de holocelulose com a adição de $\mathrm{K}$ na solução nutritiva. O uso de $175,5 \mathrm{mg}$ de $\mathrm{K} \mathrm{L}^{-1}$ na solução proporcionou ganhos médios em holocelulose de $2,3 \%$ em relação a testemunha.

Para a concentração de lignina no lenho, as progênies não diferiram apenas na dose de $175,5 \mathrm{mg}$ de $\mathrm{K} \mathrm{L}^{-1}$ (Tabela 43). Na falta e na dose de 58,5 mg de $\mathrm{K} \mathrm{L}^{-1}$, verificou-se uma inferioridade da progênie 4 em relação as demais. $\mathrm{Na}$ dose mais alta de $\mathrm{K}$, a concentração mais elevada de lignina ocorreu na progênie 2 quando comparada as outras. Independente das doses de potássio, a progênie 2 mostrou-se superior as demais para a concentração de lignina. Constatou-se ainda que a concentração de lignina foi

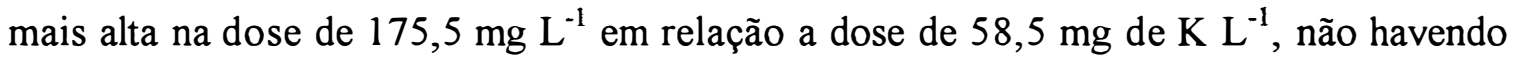
diferença significativa desta para as outras duas.

Em todas as doses de $\mathrm{K}$, ocorreram diferenças significativas entre os materiais genéticos para a concentração de extrativos na madeira (Tabela 43). A progênie 3 apresentou menor concentração de extrativos em relação as demais quando cultivada na ausência de potássio. Na dose de $58,5 \mathrm{mg} \mathrm{L}^{-1}$, a maior concentração de extrativos foi verificada na progênie 1 , a qual diferiu das progênies 3 e 4 . Na dose de $175,5 \mathrm{mg} \mathrm{L}^{-1}$, houve diferença entre a progênie 1 e as progênies 2 e 3 , com concentração mais alta na primeira. A progênie 2 quando cultivada na dose mais elevada de $\mathrm{K}$, apresentou queda na concentração de extrativos, fazendo com que esta tivesse menor concentração quando confrontada com as outras. Sem considerar as doses de K, a progênie 3 foi a que apresentou menor concentração de extrativos, diferindo das outras progênies. Independente do genótipo, as maiores concentrações de extrativos foram encontradas na testemunha e na dose de $58,5 \mathrm{mg} \mathrm{L}^{-1}$, ocorrendo diferença destas para as doses mais elevadas de $\mathrm{K}$ na solução. 
A aplicação de $\mathrm{N}$ e $\mathrm{K}$ em Gmelina arborea promoveu aumentos na concentração de extrativos da madeira (Ogbonnaya, 1994), bem como, a aplicação isolada de N, P, ou conjunta de NP e NPK em E. urophylla (Jian Ju et al., 1998). Estes efeitos foram contrários aos obtidos com a fertilização potássica neste trabalho.

Analisando as equações de regressões, verificou-se que os efeitos da aplicação de $\mathrm{K}$ sobre a concentração de extrativos e holocelulose foram mais consistentes nas progênies 1 e 2 (Figura 49). Ocorreram acréscimos lineares na concentração de holocelulose com o fornecimento de potássio às plantas, sendo a relação inversa observada para os extrativos. A maior dose de $\mathrm{K}$ proporcionou aumentos na concentração de holocelulose de $6,2 \%$ na progênie 2 e 2,3\% na progênie 1 . No entanto, na progênie 2 apesar dos aumentos na concentração de holocelulose, a aplicação de $526,5 \mathrm{mg}$ de $\mathrm{K} \mathrm{L}^{-1}$, provocou queda de $23 \%$ na quantidade de lenho em relação a dose de $175,5 \mathrm{mg} \mathrm{L}^{-1}$, resultando numa menor produção de holocelulose por árvore. Portanto, deve-se analisar os aumentos na concentração de holocelulose conjuntamente com a produção de matéria seca do lenho.

Tabela 43. Concentração de holocelulose, lignina e extrativos no lenho das progênies de Eucalyptus grandis em função das doses de potássio na solução nutritiva.

\begin{tabular}{|c|c|c|c|c|c|}
\hline \multirow[t]{2}{*}{ Material genético } & \multicolumn{4}{|c|}{$\mathrm{K}$ na solucão $\left(\mathrm{mg} \mathrm{L}^{-1}\right)$} & \multirow[b]{2}{*}{ Média } \\
\hline & 0 & 58,5 & 175,5 & 526,5 & \\
\hline & \multicolumn{4}{|c|}{ Holocelulose $\left(\mathrm{g} \mathrm{kg}^{-1}\right)$} & \\
\hline Progênie 1 & 697 b B & 697 b B & $705 \mathrm{c} \mathrm{A}$ & $712 \mathrm{~b} \mathrm{~A}$ & $702,7 \mathrm{c}$ \\
\hline Progènie 2 & 688 b B & 702 b B & 738 a A & 736 a $\mathrm{A}$ & $716,5 \mathrm{~b}$ \\
\hline Progênie 3 & 739 a $\mathrm{AB}$ & 720 a B & 744 a A & 728 a $\mathrm{AB}$ & $732,7 \mathrm{a}$ \\
\hline Progênie 4 & 722 a A & 721 a A & 722 b A & 727 a A & $723,0 \mathrm{~b}$ \\
\hline \multirow[t]{2}{*}{ Média } & $711,5 \mathrm{~B}$ & $710,0 \mathrm{~B}$ & $727,7 \mathrm{~A}$ & $725,7 \mathrm{~A}$ & \\
\hline & \multicolumn{4}{|c|}{$\operatorname{Lignina}\left(\mathrm{g} \mathrm{kg}^{-1}\right)$} & \\
\hline Progênie I & $216 a b B$ & 217 a B & 221 a $\mathrm{A}$ & $214 \mathrm{~b} \mathrm{~B}$ & $217,0 \mathrm{c}$ \\
\hline Progênie 2 & 224 a $\mathrm{AB}$ & 221 a B & 224 a AB & 233 a $\mathrm{A}$ & $226,0 \mathrm{a}$ \\
\hline Progênie 3 & 223 a A & 222 a $\mathrm{A}$ & 221 a $\mathrm{A}$ & $217 \mathrm{~b} \mathrm{~A}$ & $220,5 \mathrm{~b}$ \\
\hline Progênie 4 & $211 \mathrm{~b} \mathrm{~A}$ & $210 \mathrm{~b} \mathrm{~A}$ & 219 a $\mathrm{A}$ & $210 \mathrm{~b} \mathrm{~A}$ & $212,5 \mathrm{c}$ \\
\hline \multirow[t]{2}{*}{ Média } & $218,5 \mathrm{AB}$ & $217,5 \mathrm{~B}$ & $221,2 \mathrm{~A}$ & $218,5 \mathrm{AB}$ & \\
\hline & \multicolumn{4}{|c|}{ Extrativos $\left(\mathrm{g} \mathrm{kg}^{-1}\right)$} & \\
\hline Progênie I & 87 a $\mathrm{A}$ & 86 a A & 74 a B & 74 a B & $80,2 \mathrm{a}$ \\
\hline Progênie 2 & 88 a $\mathrm{A}$ & $77 \mathrm{ab} \mathrm{A}$ & $42 \mathrm{bc} \mathrm{B}$ & $31 \mathrm{~b} \mathrm{~B}$ & $59,5 \mathrm{~b}$ \\
\hline Progênie 3 & $38 \mathrm{~b} \mathrm{~A}$ & $58 \mathrm{c} \mathrm{A}$ & $35 \mathrm{c} \mathrm{A}$ & 55 a $\mathrm{A}$ & $46,5 \mathrm{c}$ \\
\hline Progênie 4 & 67 a A & 69 bc $A$ & 59 ab A & 63 a A & $64,2 \mathrm{c}$ \\
\hline Média & $70,0 \mathrm{~A}$ & $72,5 \mathrm{~A}$ & $52,5 \mathrm{~B}$ & $55,7 \mathrm{~B}$ & \\
\hline
\end{tabular}

Médias seguidas de mesma letra não diferem entre si (minúscula na vertical e maiuscula na horizontal) pelo teste de Tukey ao nível de $5 \%$ de probabilidade. 
Progênie 1

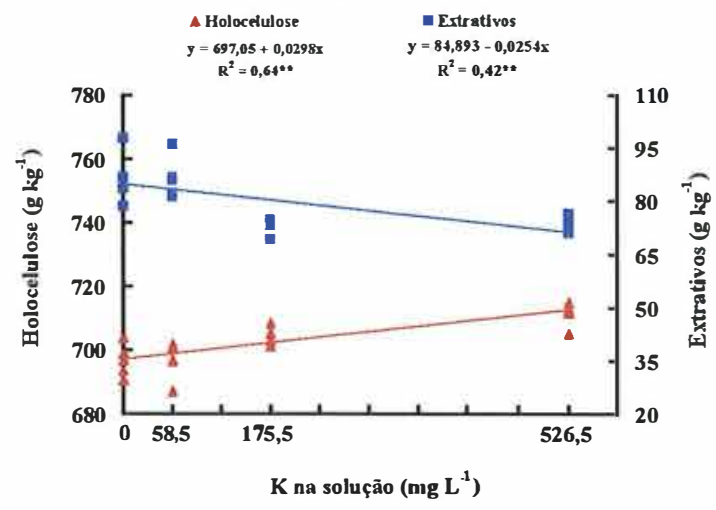

Progênie 3

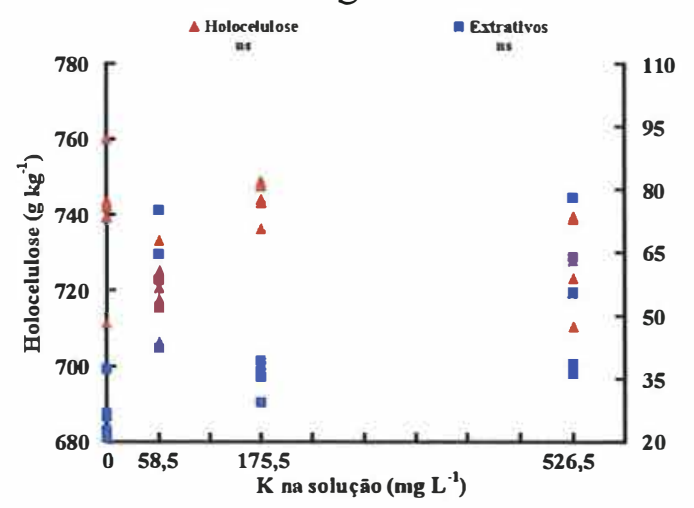

Progênie 2

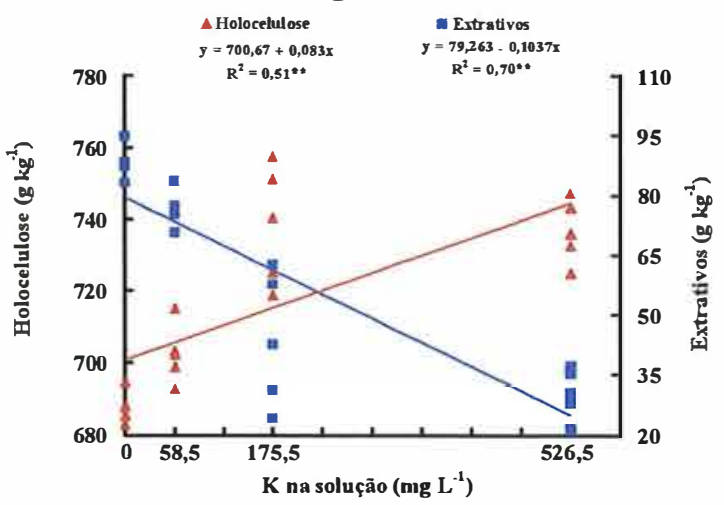

Progênie 4

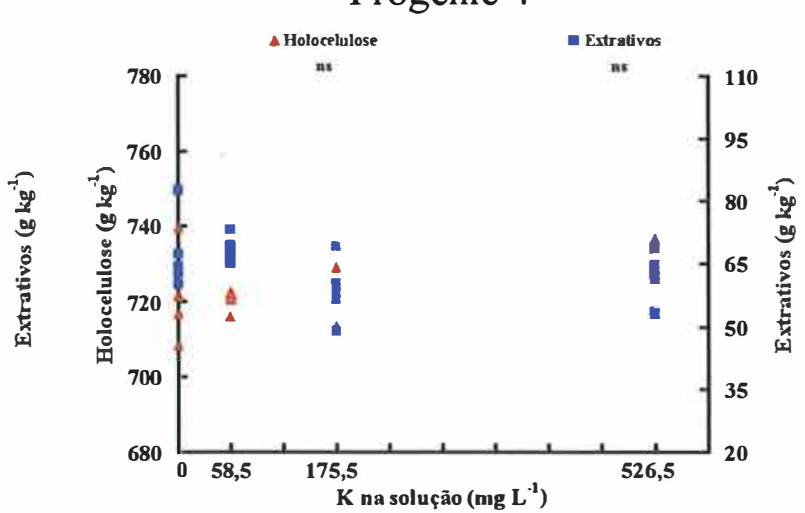

Figura 49. Relação entre as concentrações de holocelulose e extrativos no lenho das progênies de Eucalyptus grandis e as doses de potássio na solução nutritiva.

Através das equações de regressões, estimou-se que a máxima concentração de lignina nas progênies 1 e 4 ocorreu quando a dose de $\mathrm{K}$ foi de 256 e $354 \mathrm{mg} \mathrm{L}^{-1}$, respectivamente (Figura 50). Para a progênie 2, a concentração de lignina apresentou incrementos lineares com o aumento das doses de potássio, efeitos contrários foram verificados para a progênie 3 . Resultados similares aos encontrados para a progênie 3 , foram verificados com a aplicação de N e P em Pinus radiata (Downes \& Turvey, 1986). Um dos estudos envolvendo os efeitos das deficiências nutricionais sobre a composição química da madeira foi realizado por Sgarbi et al. (1999). Os autores verificaram que a deficiência de Ca reduzia o teor de lignina do lenho em híbrido de $E$. 
grandis $\mathrm{x}$ E. urophylla, enquanto que a carência de $\mathrm{K}$ não afetou o teor de lignina quando comparado ao tratamento completo.

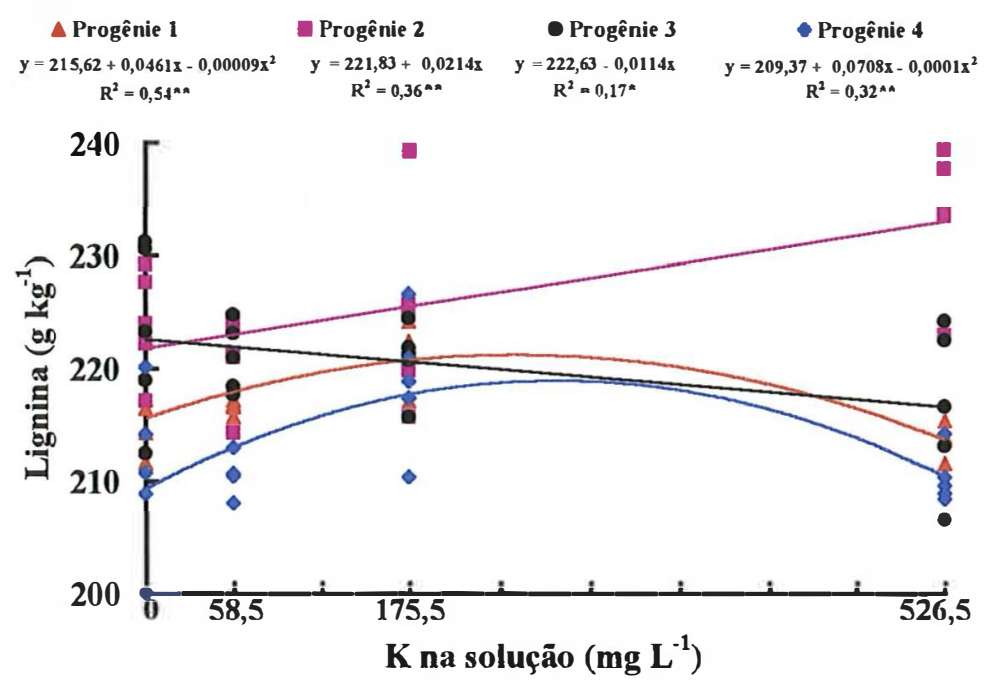

Figura 50. Relação entre as concentrações de lignina no lenho das progênies de Eucalyptus grandis e as doses de potássio na solução nutritiva.

Multiplicando-se a concentração de holocelulose, lignina e extrativos do lenho pela produção de matéria seca do lenho, obteve-se a quantidade produzida dos respectivos parâmetros químicos (Tabela 44). As análises de variância mostraram interações entre as progênies e as doses de $\mathrm{K}$ para a quantidade de holocelulose, lignina e extrativos no lenho. Na falta de potássio, a progênie 4 apresentou maior quantidade de celulose no lenho quando comparada com a progênie 2 . Na dose de 58,5 e 175,5 mg de $\mathrm{K} \mathrm{L}^{-1}$, a maior produção de celulose foi encontrada na progênie 3 , a qual diferiu das progênies 1 e 2 . Na dose mais elevada, a única diferença constatada foi que a progênie 3 produziu mais celulose que a progênie 4 . A aplicação de $175,5 \mathrm{mg}$ de $\mathrm{K} \mathrm{L}^{-1}$ promoveu aumentos na produção de celulose de $33 \%$ na progênie 2 e $46 \%$ na progênie 3 . A mesma tendência foi observada na progênie 1, com ganhos de $18 \%$ com a aplicação de 526,5 mg de $\mathrm{K} \mathrm{L}^{-1}$ em relação a testemunha. Já na progênie 4 , os aumentos na quantidade de celulose proporcionada com a aplicação de $175,5 \mathrm{mg} \mathrm{L}^{-1}$ em relação a testemunha foram de apenas $7 \%$. 
A maior quantidade de celulose com $\mathrm{O}$ aumento da dose de $\mathrm{K}$, principalmente até $175,5 \mathrm{mg}$ de $\mathrm{K} \mathrm{L} \mathrm{L}^{-1}$, poderia ser explicada pela maior taxa fotossintética das plantas associada a um maior transporte de carboidratos das folhas para o lenho, uma vez que o potássio está envolvido em ambos os processos (Mengel \& Kirkby, 1978; Malavolta, 1980; Pretty, 1982 e Marschner, 1995). Esses efeitos serão discutidos no item 4.10 .

Tabela 44. Quantidade de holocelulose, lignina e extrativos no lenho das progênies de Eucalyptus grandis em função das doses de potássio na solução nutritiva.

\begin{tabular}{|c|c|c|c|c|c|}
\hline \multirow[t]{2}{*}{ Material genético } & \multicolumn{4}{|c|}{$\mathrm{K}$ na solução (mg L $\left.\mathrm{L}^{-1}\right)$} & \multirow[b]{2}{*}{ Média } \\
\hline & 0 & 58,5 & 175,5 & 526,5 & \\
\hline & \multicolumn{5}{|c|}{ Holocelulose (g/planta) } \\
\hline Progênie l & $89,2 \mathrm{ab} \mathrm{A} \mathrm{(100)}$ & $92,9 \mathrm{c} \mathrm{A}(104)$ & $98,2 \mathrm{cA}(110)$ & $105,5 \mathrm{ab} A(118)$ & $96,4 \mathrm{c}(100)^{2}$ \\
\hline Progênie 2 & 85,5 b B (100) & 97,3 bc B (114) & 113,6 bc A (133) & 91,9 ab B (107) & $97,1 \mathrm{c}(101)$ \\
\hline Progênie 3 & 97,1 ab C (100) & 128,8 a $\mathrm{AB}(133)$ & 141,5 a A (146) & 112,3 a BC (116) & 119,9 a (124) \\
\hline Progênie 4 & 110,2 a $\mathrm{AB}(126)$ & 115,9 ab A (132) & $116,8 \mathrm{~b} \mathrm{~A}(133)$ & 87,7 b B (100) & $107,6 \mathrm{~b}(112)$ \\
\hline \multirow[t]{2}{*}{ Média } & $95,5 \mathrm{C}(100)^{3}$ & $108,7 \mathrm{AB}(114)$ & $117,5 \mathrm{~A}(123)$ & $99,3 \mathrm{BC}(104)$ & \\
\hline & \multicolumn{5}{|c|}{ Lignina (g/planta) } \\
\hline Progênie 1 & 27,7 a $\mathrm{A}(100)$ & 28,9 b A (104) & $30,8 \mathrm{~b} \mathrm{~A}(111)$ & $31,7 \mathrm{ab} A(114)$ & $29,8 \mathrm{~b}(100)$ \\
\hline Progênie 2 & 27,8 a $B(100)$ & 30,6 b B (110) & 34,5 b A (124) & 29,2 b B (105) & $30,5 \mathrm{~b}(102)$ \\
\hline Progênie 3 & 29,2 a $B(100)$ & 39,5 a A (135) & 42,0 a $\mathrm{A}(144)$ & 33,4 a B (114) & 36,0 a (121) \\
\hline Progênie 4 & 32,1 a $\mathrm{AB}(126)$ & $33,9 \mathrm{ab}$ A (133) & 35,4 b A (139) & 25,4 b B (100) & $31,7 b(106)$ \\
\hline \multirow[t]{2}{*}{ Média } & $29,2 \mathrm{~B}(100)$ & $33,2 \mathrm{~A}(114)$ & $35,7 \mathrm{~A}(122)$ & 29,9 B (102) & \\
\hline & \multicolumn{5}{|c|}{ Extrativos (g/planta) } \\
\hline Progênie 1 & 11,2 a $A(110)$ & 11,5 a $A(113)$ & 10,2 a A (100) & 11,1 a A (109) & 11,0 a (145) \\
\hline Progênie 2 & 11,0 a A (289) & 10,6 a $\mathrm{A}(279)$ & 6,5 b B (171) & 3,8 b B $(100)$ & 8,0 bc (105) \\
\hline Progênie 3 & 4,9 b B (100) & 10,6 a $\mathrm{A}(216)$ & 6,7 b AB (137) & 8,4 a $\mathrm{AB}(171)$ & $7,6 \mathrm{c}(100)$ \\
\hline Progênie 4 & 10,2 a $\mathrm{AB}(134)$ & 11,1 a $A(146)$ & $9,4 \mathrm{ab} \mathrm{AB}(124)$ & 7,6 a $\mathrm{B}(100)$ & $9,6 \mathrm{ab}(126)$ \\
\hline Média & $9,3 \mathrm{AB}(121)$ & 10,9 A (141) & 8,2 B (106) & $7,7 \mathrm{~B}(100)$ & \\
\hline
\end{tabular}

\subsubsection{Efeito da concentração de potássio e dos macronutrientes nas} folhas diagnóstico e no lenho

Foram determinados os coeficientes de correlações de Pearson entre as concentrações dos macronutrientes nas folhas diagnóstico e no lenho e as concentrações dos parâmetros químicos no lenho (Tabela 45). Foram encontradas correlações positivas 
entre a concentração de holocelulose e a concentração de potássio, tanto nas folhas diagnóstico como no lenho, para as progênie $1(\mathrm{r}=0,80$ para as folhas; $r=0,78$ para 0 lenho) e $2(r=0,83$ para as folhas; $r=0,82$ para o lenho). Verificou-se ainda correlações negativas entre a concentração de holocelulose e a de cálcio para ambas as progênies, porém, somente nas folhas diagnóstico. Para o magnésio, aumentando-se as concentrações, tanto nas folhas como no lenho, ocorriam decréscimos nas concentrações de holocelulose das progênies 1 e 2. Observou-se decréscimos na concentração de lignina com o aumento da concentração de $\mathrm{N}$ nas folhas da progênie 1 e no lenho da progênie 4, conforme verificado também por Downes \& Turvey (1986) em Pinus radiata. No entanto, o comportamento da progênie 1 em relação a lignina, foi diferente para a concentração de $\mathrm{N}$ no lenho. Os efeitos da concentração de $\mathrm{K}$ nas folhas e no lenho sobre a concentração de lignina das progênies 2 e 3 foram distintos, uma vez que aumentos na concentração de $\mathrm{K}$ nas folhas e no lenho propiciaram maiores teores de lignina na progênie 2. O aumento da concentração de Ca nas folhas e no lenho resultou em aumento no teor de lignina, somente na progênie 3. Tal resultado também foi observado por Sgarbi et al. (1999), quando comparou plantas de E. grandis $\mathrm{x} E$. urophylla normais e deficientes em cálcio. De maneira geral, as correlações entre as concentrações de extrativos e a dos macronutrientes nas folhas e no lenho foram inversas as observadas para a concentração de holocelulose.

A Figura 51 mostra as equações de regressões entre a concentração e a quantidade de holocelulose em função do potássio nas folhas diagnóstico. A progênie 1 foi a única com tendência de aumentos lineares na concentração e na quantidade de holocelulose conforme aumentou-se a concentração de potássio nas folhas. As progênies 3 e 4 apresentaram relações quadráticas somente entre a quantidade de holocelulose e a concentração foliar de $\mathrm{K}$. Através das equações de regressões estimou-se a concentração de $\mathrm{K}$ necessária para a obtenção da máxima produção, sendo de $10,8 \mathrm{~g} \mathrm{~kg}^{-1}$ para a progênie 3 e $8,7 \mathrm{~g} \mathrm{~kg}^{-1}$ para a progênie 4 . Para a progênie 2 , a resposta foi linear para a concentração e quadrática para a quantidade de holocelulose com aumento do potássio no tecido foliar. A máxima produção de celulose foi obtida quando as plantas 


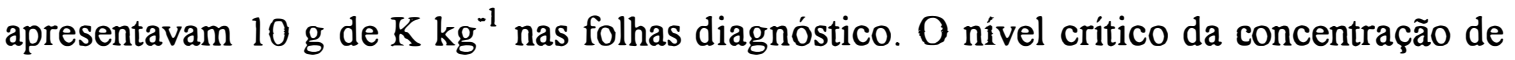
$\mathrm{K}$ nas folhas diagnóstico para a quantidade de celulose produzida foi de $\left(\mathrm{g} \mathrm{kg}^{-1}\right): 4,8$ para a progênie $2 ; 6,3$ para a progênie 3 e 3,4 para a progênie 4 . Os níveis críticos de $K$ nas folhas obtidos para a produção de celulose foram próximos dos encontrados para a produção de lenho, os quais foram de $\left(\mathrm{g} \mathrm{kg}^{-1}\right)$ : 4,2 para a progênie $2 ; 6,4$ para a progênie 3 e 3,1 para a progênie 4 .

Tabela 45. Coeficientes de correlações de Pearson entre a concentração dos macronutrientes nas folhas diagnóstico e no lenho e a concentração de holocelulose, lignina e extrativos no lenho nas progênies de Eucalyptus grandis.

\begin{tabular}{|c|c|c|c|c|c|c|c|c|c|c|c|c|}
\hline \multirow{2}{*}{$\begin{array}{l}\text { Material } \\
\text { genético }\end{array}$} & \multicolumn{2}{|c|}{$N$} & \multicolumn{2}{|c|}{$\mathrm{P}$} & \multicolumn{2}{|c|}{$\mathrm{K}$} & \multicolumn{2}{|c|}{$\mathrm{Ca}$} & \multicolumn{2}{|c|}{$\mathrm{Mg}$} & \multicolumn{2}{|c|}{$S$} \\
\hline & FD & $\mathrm{L}^{2}$ & FD & $\mathrm{L}$ & FD & $\mathrm{L}$ & FD & $\mathrm{L}$ & FD & $\mathrm{L}$ & FD & $\mathrm{L}$ \\
\hline & \multicolumn{12}{|c|}{ Holocelulose } \\
\hline Progênie l & $\mathrm{ns}$ & $\mathrm{ns}$ & $\mathrm{ns}$ & $\mathrm{ns}$ & $0,80^{* *}$ & $0,78^{* *}$ & $-0,71^{* *}$ & $\mathrm{~ns}$ & $-0,71 * *$ & $-0,63 * *$ & $-0,63 * *$ & $-0,77 * *$ \\
\hline Progênie 2 & $\mathrm{~ns}$ & $\mathrm{~ns}$ & $\mathrm{~ns}$ & ns & $0,83^{* *}$ & $0,82 * *$ & $-0,63 * *$ & $\mathrm{~ns}$ & $-0,67 * *$ & $-0.51^{* *}$ & $-0,78^{* *}$ & $-0,87^{* *}$ \\
\hline Progênie 3 & ns & ns & ns & ns & ns & $\mathrm{ns}$ & $\mathrm{ns}$ & $\mathrm{ns}$ & $\mathrm{ns}$ & ns & $\mathrm{ns}$ & ns \\
\hline Progênie 4 & ns & & ns & ns & $\mathrm{ns}$ & ns & ns & $\mathrm{ns}$ & $\mathrm{ns}$ & $\mathrm{ns}$ & ns & ns \\
\hline \multirow[t]{2}{*}{ Todos } & ns & ns & ns & ns & $0,34 * *$ & $0.32^{* *}$ & $-0,35 * *$ & $\mathrm{~ns}$ & ns & $-0.32 * *$ & $-0,27^{*}$ & $-0,36 * *$ \\
\hline & \multicolumn{12}{|c|}{ Lignina } \\
\hline Progênie l & $\mathrm{ns}$ & $0,65 * *$ & ns & $\overline{\mathrm{ns}}$ & $\overline{\mathrm{ns}}$ & $\overline{\mathrm{ns}}$ & $\mathrm{ns}$ & ns & $\overline{\mathrm{ns}}$ & ns & $\mathrm{ns}$ & ns \\
\hline Progênie 2 & $-0.55 * *$ & ns & ns & ns & $0.55 * *$ & $0,49^{* *}$ & $\mathrm{~ns}$ & $\mathrm{~ns}$ & $-0,44 * *$ & ns & ns & ns \\
\hline Progênie 3 & ns & ns & ns & ns & $-0.39 * *$ & $-0.39 * *$ & $0.50 *$ & $0.55 * *$ & ns & $0.5+* *$ & ns & ns \\
\hline Progênie 4 & ns & ns & ns & ns & ns & ns & ns & $\mathrm{ns}$ & $\mathrm{ns}$ & ns & ns & ns \\
\hline \multirow[t]{2}{*}{ Todos } & $-0,27^{*}$ & ns & $-0,27 *$ & ns & ns & ns & ns & ns & ns & ns & $-0,22 *$ & ns \\
\hline & \multicolumn{12}{|c|}{ Extrativos } \\
\hline Progênie 1 & ns & $\mathrm{ns}$ & ns & ns & $-0.61^{* *}$ & $-0.79 * *$ & $0,75^{* *}$ & $\mathrm{~ns}$ & $0,78^{* *}$ & $0.58 * *$ & $0,69 * *$ & $0.64 * *$ \\
\hline Progênie 2 & ns & ns & ns & ns & $-0,91 * *$ & $-0.89 * *$ & $0,71^{* *}$ & ns & $0,71^{* *}$ & $0.49 * *$ & $0.76^{* *}$ & $0.85 * *$ \\
\hline Progênie 3 & ns & ns & ns & ns & ns & ns & $\mathrm{ns}$ & ns & ns & ns & ns & ns \\
\hline Progênie 4 & ns & $0,59 * *$ & ns & ns & $-0,42 * *$ & $-0,41^{* *}$ & $\mathrm{~ns}$ & ns & ns & ns & ns & $0,51^{* *}$ \\
\hline Todos & ns & ns & ns & ns & $-0,30 * *$ & $-0,33^{* *}$ & $0,32 * *$ & ns & ns & ns & $0,29 * *$ & $0.29 * *$ \\
\hline
\end{tabular}

1 - folha diagnóstico: 2 - lenho; ** - significativo a $1 \%$ de probabilidade; * - significativo a $5 \%$ de probabilidade; ns - não significativo. 

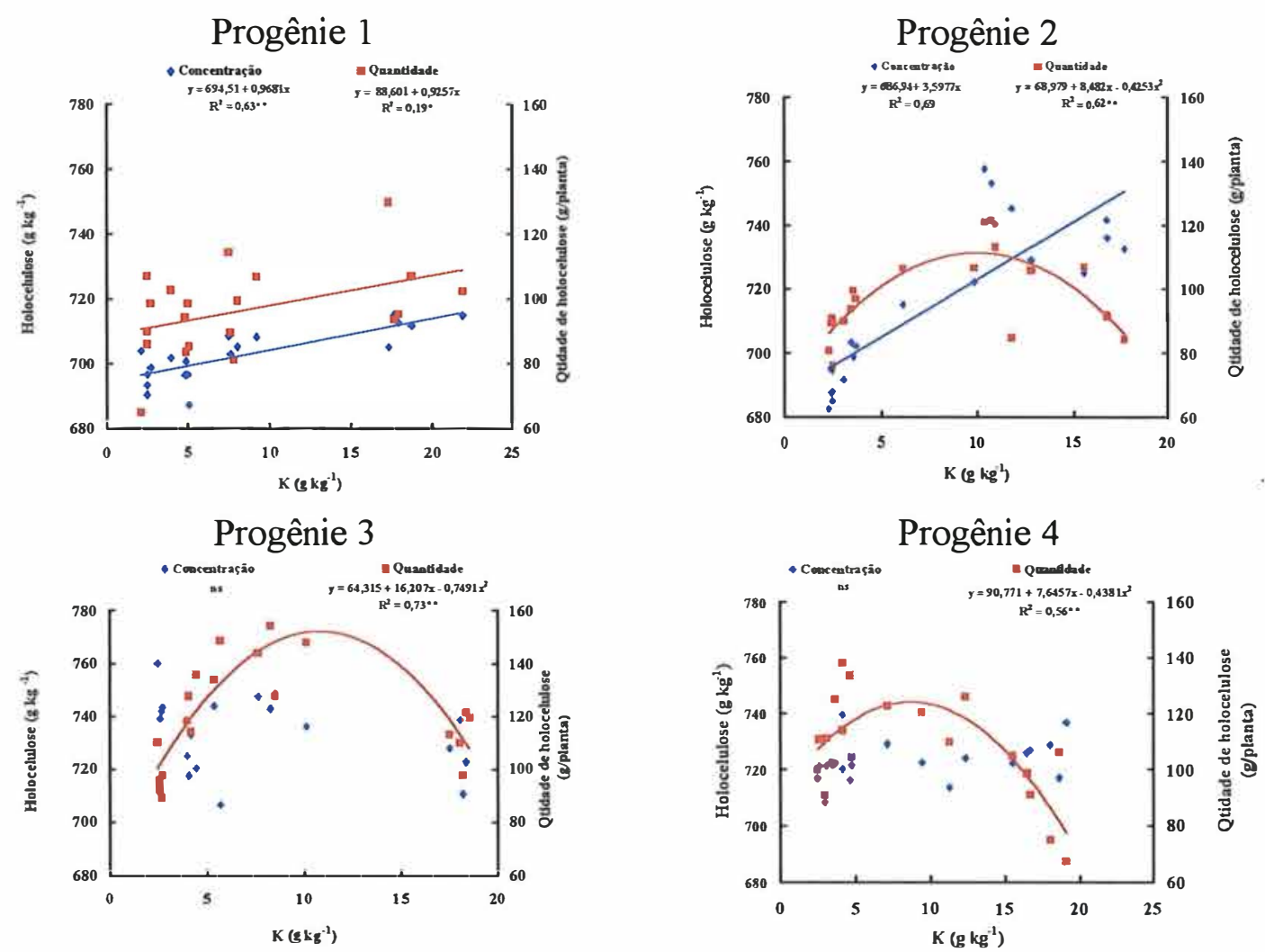

Figura 51. Relação entre a concentração e quantidade de holocelulose no lenho e a concentração de potássio nas folhas diagnóstico das progênies de Eucalyptus grandis.

\subsubsection{Efeito das relações $\mathrm{N} / \mathrm{K}, \mathrm{K} / \mathrm{P}, \mathrm{K} / \mathrm{Ca}, \mathrm{K} / \mathrm{Mg}$ e $\mathrm{K} / \mathrm{Ca}+\mathrm{Mg}$ nas folhas diagnósticos e no lenho}

A Tabela 46 mostra os coeficientes de correlações de Pearson entre as relações $\mathrm{N} / \mathrm{K}, \mathrm{K} / \mathrm{P}, \mathrm{K} / \mathrm{Ca}, \mathrm{K} / \mathrm{Mg}$ e $\mathrm{K} / \mathrm{Ca}+\mathrm{Mg}$ no lenho e a concentração de holocelulose, lignina e extrativos dos materiais genéticos. Os efeitos da razão N/K no lenho sobre a concentração de holocelulose foram significativos apenas para a progênie 4. Com aumento da relação $\mathrm{N} / \mathrm{K}$ na madeira houve diminuição da concentração de holocelulose, sendo os efeitos inversos para a concentração de extrativos. A progênie 1 apresentou correlação positiva entre a relação $\mathrm{N} / \mathrm{K}$ no lenho e o teor de lignina. A relação $\mathrm{K} / \mathrm{P}$ no lenho não influenciou nas características química da madeira. A relação $\mathrm{K} / \mathrm{Ca}$ no lenho foi a que melhor correlacionou com a 
concentração de holocelulose e extrativos no lenho. Tanto na progênie 1 como na 2, aumentos da razão $\mathrm{K} / \mathrm{Ca}$ no lenho causaram incrementos na concentração de holocelulose. A influência da relação $\mathrm{K} / \mathrm{Mg}$ do lenho sobre as características químicas da madeira foi pequena quando comparadas com a razão $\mathrm{K} / \mathrm{Ca}$.

Tabela 46. Coeficientes de correlações de Pearson entre a razão N/K, K/P, K/Ca, K/Mg e K/Ca+Mg no lenho e a concentração de holocelulose, lignina e extrativos no lenho das progênies de Eucalyptus grandis.

\begin{tabular}{|c|c|c|c|c|c|}
\hline $\begin{array}{r}\text { Material } \\
\text { Genético } \\
\end{array}$ & $\mathrm{N} / \mathrm{K}$ & $\bar{K} / \mathrm{P}$ & $\mathrm{K} / \mathrm{Ca}$ & $\mathrm{K} M \mathrm{Mg}$ & $\mathrm{K} / \mathrm{Ca}+\mathrm{Mg}$ \\
\hline & \multicolumn{5}{|c|}{ Holocelulose } \\
\hline Progênie I & $\mathrm{ns}$ & ns & $0,78^{* *}$ & ns & $-0,63 * *$ \\
\hline Progênie 2 & ns & ns & $0,82 * *$ & ns & $-0,52 *$ \\
\hline Progênie 3 & ns & ns & ns & ns & ns \\
\hline Progênie 4 & $-0,58^{*}$ & ns & ns & $-0,40 *$ & ns \\
\hline \multirow[t]{2}{*}{ Todos } & ns & ns & $0,32 * *$ & ns & $-0,32 * *$ \\
\hline & \multicolumn{5}{|c|}{ Lignina } \\
\hline Progênie 1 & $0,65 * *$ & ns & $\mathrm{ns}$ & ns & ns \\
\hline Progênie 2 & ns & ns & $0,49^{*}$ & ns & ns \\
\hline Progênie 3 & ns & ns & $-0,40^{*}$ & $0,55^{* *}$ & $0,54 * *$ \\
\hline Progênie 4 & ns & ns & ns & ns & ns \\
\hline \multirow[t]{2}{*}{ Todos } & ns & ns & ns & ns & ns \\
\hline & \multicolumn{5}{|c|}{ Extrativos } \\
\hline Progênie 1 & ns & ns & $-0,79 * *$ & $\mathrm{~ns}$ & $0,58 * *$ \\
\hline Progênie 2 & ns & ns & $-0,89 * *$ & ns & $0,48 *$ \\
\hline Progênie 3 & ns & ns & ns & ns & ns \\
\hline Progênie 4 & $0,59 * *$ & ns & $-0,41^{*}$ & ns & ns \\
\hline Todos & ns & ns & $-0,33 * *$ & ns & ns \\
\hline
\end{tabular}

* - significativo a $5 \%$ de probabilidade; ** - significativo a I \% de probabilidade: ns - não significativo

Os efeitos da razão N/K nas folhas sobre a concentração e quantidade de holocelulose foram similares para as progênies 1 e 2 . Ocorreram quedas lineares tanto na concentração como na quantidade de holocelulose com o aumento da relação $N / K$. Para as progênies 3 e 4, o efeito da relação $N / K$ foi marcante somente para a quantidade de celulose produzida. A máxima produção de celulose foi alcançada quando a razão foliar $\mathrm{N} / \mathrm{K}$ era de 4,2 para a progênie 3 e 5,5 para a progênie 4 (Figura 52). 
As progênies 1 e 2 apresentaram respostas quadráticas para concentração e quantidade de holocelulose conforme variou-se a relação $\mathrm{K} / \mathrm{P}$ nas folhas diagnóstico (Figura 53). A maior concentração de holocelulose foi obtida quando as plantas apresentavam relação $\mathrm{K} / \mathrm{P}$ de 15,7 e 10,3 no caso das progênies 1 e 2, respectivamente. A máxima quantidade de celulose produzida ocorreu quando as plantas das progênies 1 e 2 tinham $11,7 \mathrm{~K} / 1 \mathrm{P}$ e $8,2 \mathrm{~K} / 1 \mathrm{P}$, respectivamente. As relações entre a razão $\mathrm{K} / \mathrm{P}$ nas folhas e a concentração de holocelulose não foram significativas para as progênies 3 e 4 . No entanto, para a quantidade de holocelulose verificou-se relação quadrática em função da razão $\mathrm{K} / \mathrm{P}$ em ambas as progênies. A razão $\mathrm{K} / \mathrm{P}$ foliar de 8,5 e 5,4 para as progênies 3 e 4 , foram as que proporcionaram a máxima produção de celulose.
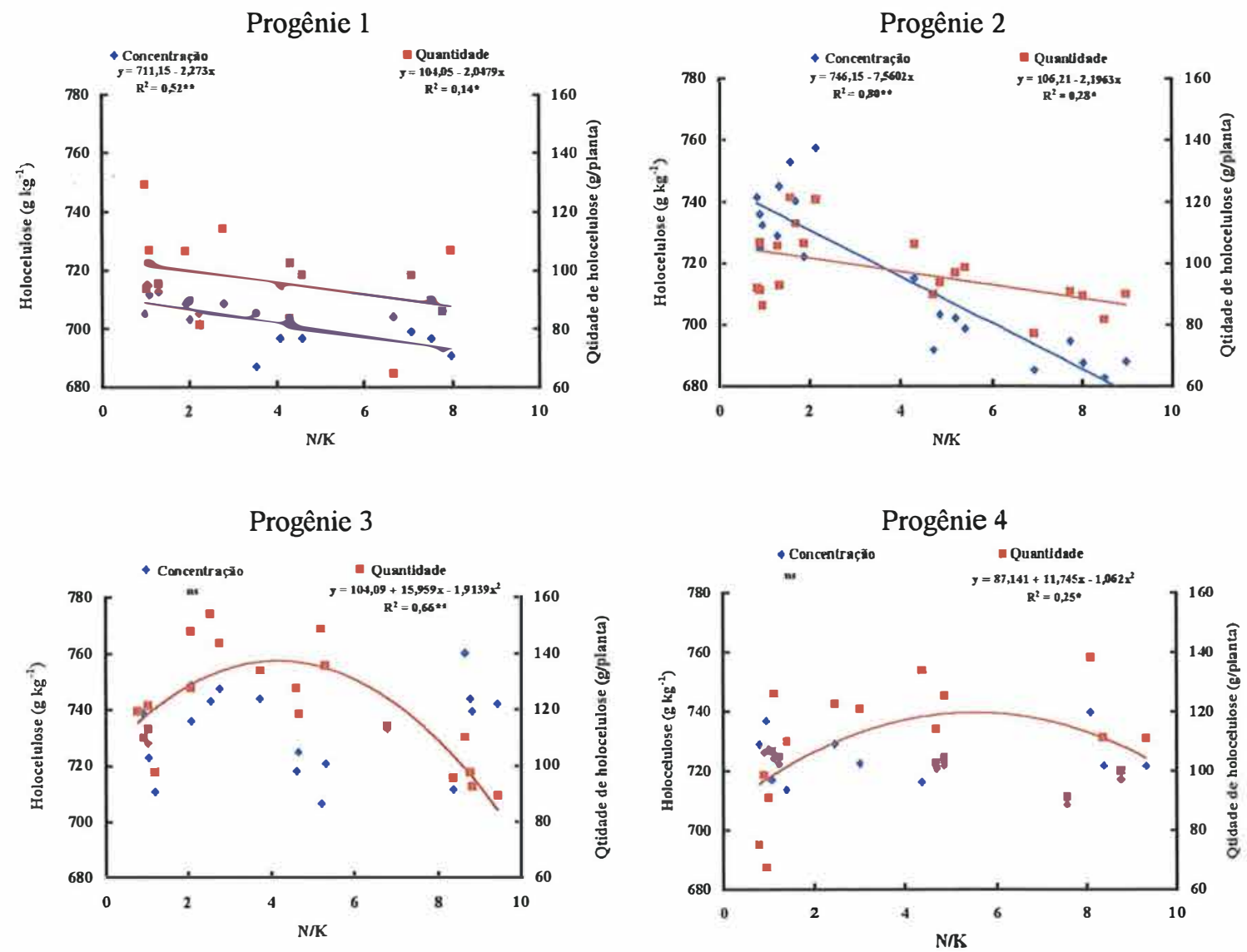

Figura 52. Relação entre a concentração e quantidade de holocelulose no lenho e a razão N/K nas folhas diagnóstico das progênies de Eucalyptus grandis. 

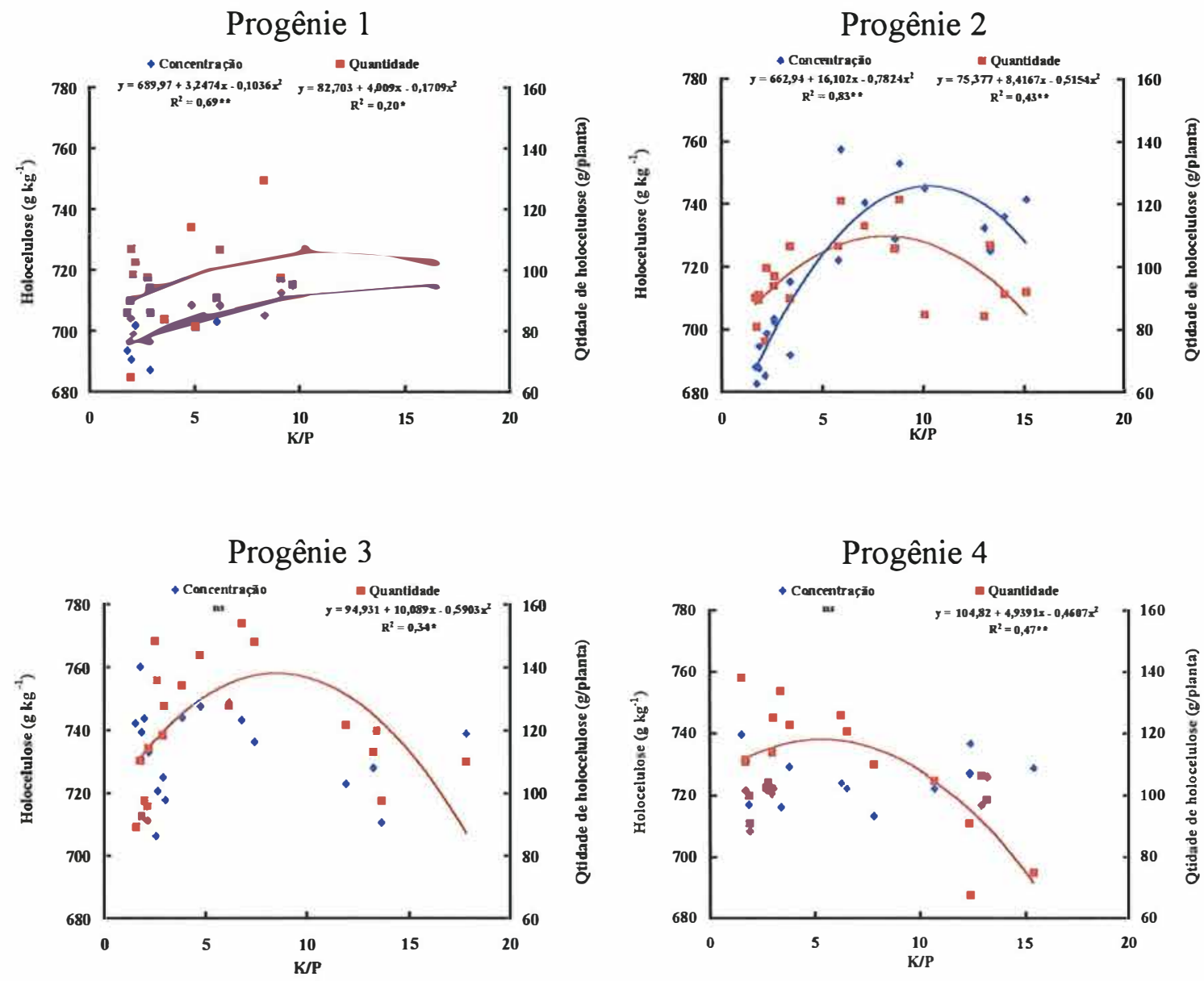

Figura 53. Relação entre a concentração e quantidade de holocelulose no lenho e a razão K/P nas folhas diagnóstico das progênies de Eucalyptus grandis.

Foram encontradas respostas quadráticas para a concentração e quantidade de holocelulose em função da razão $\mathrm{K} / \mathrm{Ca}$ nas folhas diagnóstico das progênies 1 e 2 (Figura 54). A máxima concentração de holocelulose no lenho foi obtida quando a relação $\mathrm{K} / \mathrm{Ca}$ era de 3,7 e 1,8 para as progênies 1 e 2 , respectivamente. $\mathrm{O}$ maior conteúdo de holocelulose no lenho foi alcançado quando a razão foliar $\mathrm{K} / \mathrm{Ca}$ era de: 3,0 para a progênie $1,1,5$ para a progênie $2,1,6$ para a progênie 3 e 1,3 para a progênie 4 . 

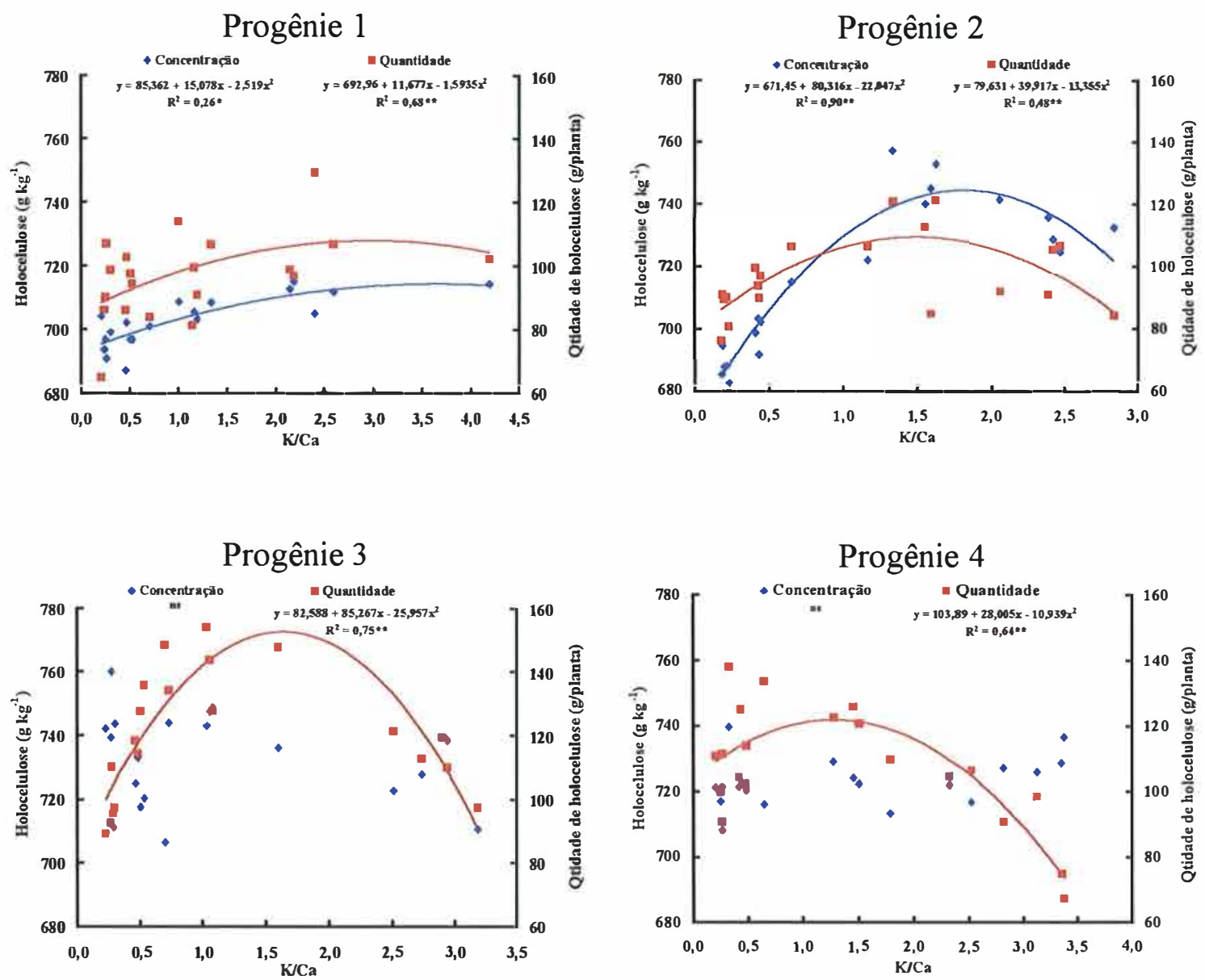

Figura 54. Relação entre a concentração e quantidade de holocelulose no lenho e a razão K/Ca nas folhas diagnóstico das progênies de Eucalyptus grandis.

A Figura 55 mostra a concentração e quantidade de holocelulose no lenho dos materiais genéticos em função da relação $\mathrm{K} / \mathrm{Mg}$ nas folhas diagnóstico. Na progênie 1 ocorreu queda linear na quantidade de holocelulose com o aumento da relação $\mathrm{K} / \mathrm{Mg}$ nas folhas, o contrário foi observado para a concentração. As relações entre a concentração e a quantidade de holocelulose e a razão $\mathrm{K} / \mathrm{Mg}$ nas folhas foram quadráticas para a progênie 2. A máxima concentração e o maior acúmulo ocorreram quando as relações $\mathrm{K} / \mathrm{Mg}$ eram de 3,1 e 2,4, respectivamente. Para as progênies 3 e 4, verificaram-se aumentos da produção de celulose com o aumento da relação $\mathrm{K} / \mathrm{Mg}$ nas 
folhas. A máxima produção de celulose foi alcançada quando a relação $\mathrm{K} / \mathrm{Mg}$ era de 2,4 e 2,0 nas progênies 3 e 4, respectivamente.
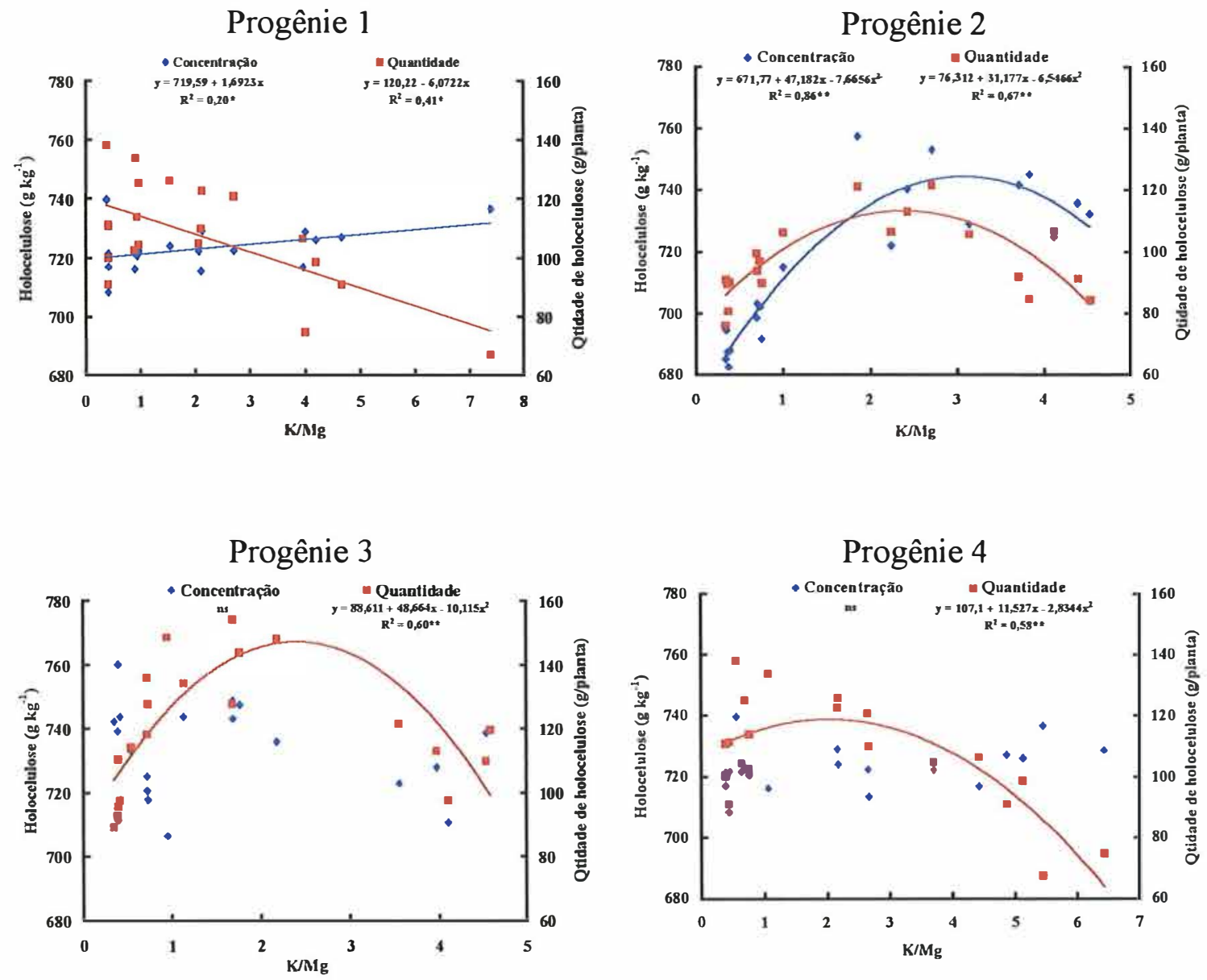

Figura 55. Relação entre a concentração e quantidade de holocelulose no lenho e a razão $\mathrm{K} / \mathrm{Mg}$ nas folhas diagnóstico das progênies de Eucalyptus grandis. 


\subsection{Relação entre açúcares solúveis totais nas folhas diagnóstico e holocelulose no lenho em função das doses de potássio}

Os dados de concentração de holocelulose no lenho e açúcares solúveis totais nas folhas diagnóstico em função da dose de $\mathrm{K}$ na solução encontram-se na figura 56. Aumentos na concentração de holocelulose no lenho estavam relacionados com decréscimos na concentração de açúcares nas folhas a medida que se aumentava o fornecimento de potássio às plantas, principalmente nas progênie 1,2 e 3. A hipótese seria que com o aumento da dose de potássio, estaria ocorrendo um maior transporte de carboidratos solúveis das folhas para o lenho, resultando consequentemente num maior acúmulo de celulose e hemicelulose. Esses resultados evidenciam a importância do $\mathrm{K}$ no transporte de fotossintetizados das folhas para os orgãos de armazenamento conforme relatados por Mengel \& Kirkby (1978), Malavolta (1980), Marschner (1995) e Malavolta et al. (1997).

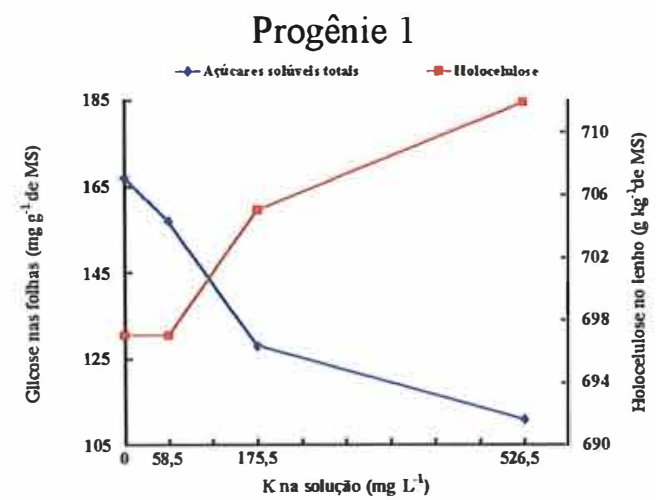

Progênie 3

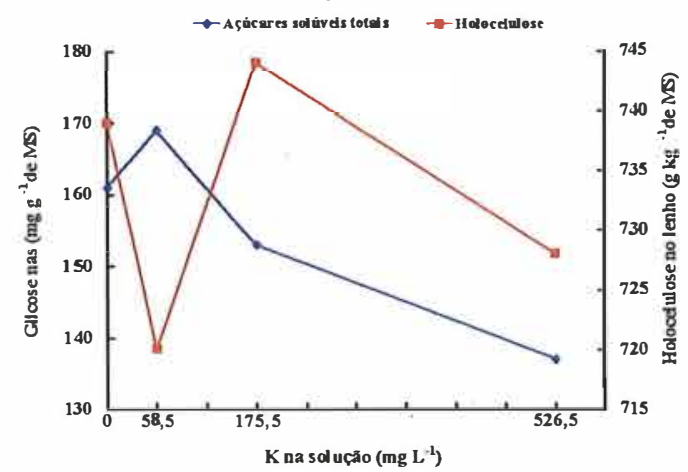

Progênie 2

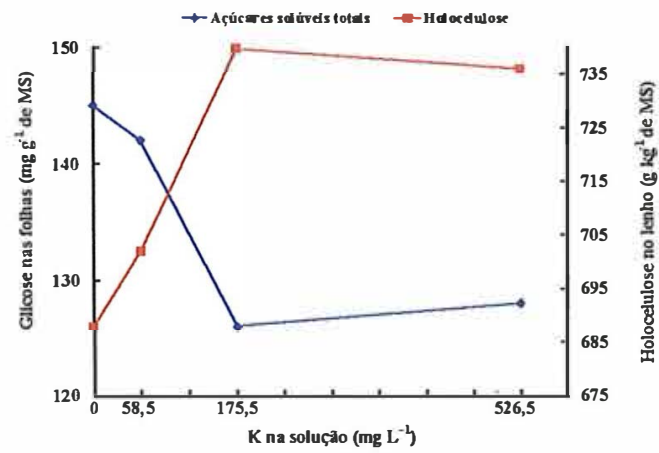

Progênie 4

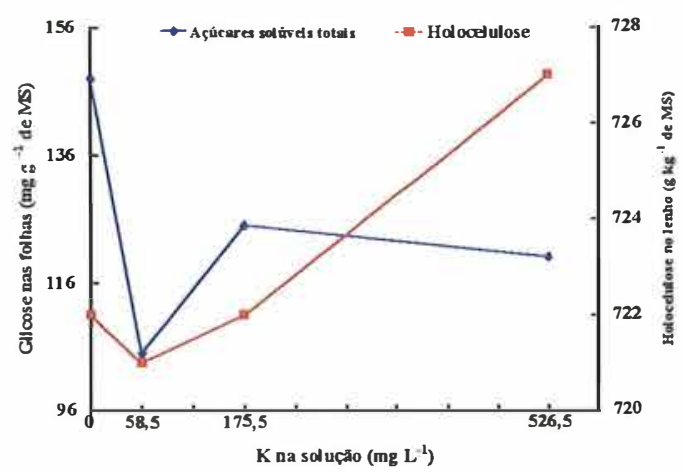

Figura 56. Valores médios das concentrações de açúcares solúveis totais nas folhas diagnóstico e de holocelulose no lenho das progênies de Eucalyptus grandis em função das doses de potássio na solução nutritiva 


\section{CONCLUSŌES}

Nas condições em que foi realizado o experimento, as principais conclusões foram:

1. Para a produção de lenho e de holocelulose, os materiais genéticos de Eucalyptus grandis responderam de maneira diferenciada a aplicação de potássio, sendo as progênies 2 e 3 consideradas responsivas e as progênies 1 e 4 não responsivas.

2. Em todas as progênies, a concentração de $\mathrm{Ca}$ e $\mathrm{Mg}$ nos tecidos vegetais, principalmente nas folhas, foi afetada negativamente com o aumento da dose de potássio na solução nutritiva.

3. O aumento da concentração de potássio na solução nutritiva diminuiu principalmente o teor de cobre nas folhas novas, zinco nas folhas diagnóstico e manganês nas folhas velhas de todos os genótipos.

4. A faixa adequada de potássio nas folhas diagnóstico variou bastante em função do material genético analisado. O nível crítico de potássio nas folhas diagnóstico foi de $6,4 \mathrm{~g} \mathrm{~kg}^{-1}, 4,2 \mathrm{~g} \mathrm{~kg}^{-1}$ e $3,1 \mathrm{~g} \mathrm{~kg}^{-1}$ para as progênies $3,2 \mathrm{e} 4$. No entanto, não foi possível definir o nível crítico para a progênie 1 .

5. A quantidade total extraída de $\mathrm{N}, \mathrm{Ca}, \mathrm{Mg}$ e $\mathrm{S}$ diminuiu com o aumento da dose de potássio na solução nutritiva.

6. A quantidade total extraída de $\mathrm{Cu}, \mathrm{Mn}$ e $\mathrm{Zn}$ diminuiu com o aumento da concentração de potássio na solução nutritiva, principalmente para as progênies 1 e 4 
7. As progênies apresentaram respostas diferenciadas quanto a utilização de potássio para a produção de lenho e celulose. A progênie 2 foi considerada menos eficiente.

8. A deficiência de potássio causou acúmulo tóxico de putrescina nas folhas diagnóstico de todas as progênies. A concentração de espermina e espermidina não foi afetada pelas doses de potássio na solução nutritiva.

9. As progênies apresentaram comportamentos distintos para a concentração de açúcares solúveis totais nas folhas diagnóstico. Nas progênies 1 e 3, o aumento da dose de $\mathrm{K}$ na solução proporcionou decréscimos na concentração de açúcares.

10. As progênies tiveram comportamentos diferenciados para a densidade básica do lenho conforme variou-se a dose de potássio na solução nutritiva.

11. As maiores doses de potássio na solução proporcionaram aumento no comprimento e na largura das fibras dos genótipos, com exceção da progênie 1.

12. Os materiais genéticos apresentaram respostas diferenciadas para a espessura da parede das fibras em função da dose de potássio na solução nutritiva. $\mathrm{Na}$ progênie 1 , houve decréscimo da espessura da parede com o aumento da dose de potássio.

13. Nas progênies 2 e 3 , doses crescentes de potássio na solução nutritiva causaram aumento do diâmetro do lume das fibras.

14. Houve redução da fração parede das fibras das progênies 1,2 e 3 com o aumento da dose de potássio na solução nutritiva.

15. Os materiais genéticos apresentaram respostas distintas para a concentração de holocelulose no lenho em função da dose de potássio na solução nutritiva. A adição de potássio aumentou a concentração de holocelulose nas progênies $1 \mathrm{e}$ 2 . 


\section{REFERÊNCIAS BIBLIOGRÁFICAS}

ANDRADE, A.M; VITAL, B.R.; BARROS, N.F.; DELLA LUCIA, R.M.; CAMPOS, J.C.C.; VALENTE, D.F. Efeitos da fertilização mineral e da calagem do solo na produção e na qualidade da madeira de eucalipto. Revista Árvore, v. 18, n. 1, p.69-78. 1994.

BALLONI, E.A. Efeitos da fertilização mineral sobre o desenvolvimento do Pinus caribaea Morelet var. bahamensis (Guiseb) Barret e Golfari em solo cerrado do Estado de São Paulo. Piracicaba, 1984. 110p. Dissertação (Mestrado) - Escola Superior de Agricultura "Luiz de Queiroz", Universidade de São Paulo.

BAMBER, R.K.; HORNE, R.; GRAHAM-HIGGS, A. Effect of fast growth on the properties of Eucalyptus grandis. Australian Forest Research, v.12, n.2, p. 163-167, 1982.

BARRICHELO, L.E.G.; FOELKEL, C.E.B. Processo nítrico-acético para maceração de madeiras. Silvicultura, v.28, n.28, p.732-33. 1983.

BARRICHELO, L.E.G.; SHIMOYAMA, V.R.S. Importância da adubação na qualidade da madeira e celulose. In: SÁ, M.E.; BUZETTI, S. (Ed). Importância da adubação na qualidade dos produtos agrícolas. São Paulo: Cone, 1994. cap.9, p.153-160.

BARROS, N.F. CARMO, D.N.; CALAIS, D; VIEIRA, F.S. Biomassa, absorção e eficiência de utilização de nutrientes por clones de eucalipto na região norte do Espírito Santo. In: CONGRESSO BRASILEIRO DE CIÊNCIA DO SOLO, XX., Belém, 1985. Programas e resumos, Belém: Sociedade Brasileira de Ciência do Solos. 1985. p. 109. 
BARROS, N.F.; BRAGA, J.M.; BRANDI, R.M.; DEFELIPO, B.V. Produção de eucalipto em solos de cerrado em resposta à aplicação de NPK e de B e Zn. Revista Árvore, v.5, n. 1, p.90-103, 1981.

BARROS, N.F.; NOVAIS, R.F. Eucalypt nutrition and fertilizer regimes in Brazil. In: ATTIWILL, P.M.; ADAMS, M.A.(Eds). Nutrition of Eucalyptus. CSIRO Australia. 1996 p. 335-355.

BARROS, N.F.; NOVAIS, R.F.; NEVES, J.C.L. Fertilização e correção do solo para o plantio de eucalipto. In: BARROS, N.F.; NOVAIS, R.F.(Eds) Relação SoloEucalipto. Ed. Folha de Viçosa, Viçosa. 1990. cap.4, p. 127-86.

BARROS, N.F.; NOVAIS, R.F.; NEVES, J.C.L.; Leal, P.G.L. Fertilizing eucalypt plantations on the Brazilian savannah soils. South African Forestry Journal, v.160, p.7-12. 1992.

BELLOTE, A.F.J. Nahrelement versorgung und werches - leistung von gedungten Eucalyptus grandis- plantagen in Cerrado von São Paulo (Brasilien). Freiburg, 1990. 159 p. Tese (Doutorado) - Albert Ludwigo- Universitat.

BELLOTE, A.F.J.; FERREIRA, C.A. Nutrientes minerais e crescimento de árvores adubadas de Eucalyptus grandis, na região do cerrado, no Estado de São Paulo. Boletim Pesquisa Florestal, v.26/27, p.17-65. 1993.

BELLOTTE, A.F.J. Concentração, acumulação e exportação de nutrientes pelo Eucalyptus grandis (Hill ex maiden) em função da idade. Piracicaba, 1979. 129p. Dissertação (Mestrado) - Escola Superior de Agricultura "Luiz de Queiroz", Universidade de São Paulo. 
BERINGER, H; NOTHDURFT, F. Effects of potassium on plant and cellular structures. In: MUNSON, R.D. (Ed.). Potassium in Agriculture: American Society of Agronomy, Inc.; Crop Science Society of America, Inc.; Soil Science Society of America, Inc. Madison, cap.14, p.35-67. 1985.

BEVEGE, D.I. Wood yield and quality in relation to tree nutrition. In: Bowen, G.D.; Nambiar, E.K.S. (Ed.). Nutrition of Plantation Forests. Orlando: Academic Press, 1984. Cap.11, p.293-326.

BISSET, I.J.W.; DADSWELL, H.E.; WARDROP, A.B. Factors influencing tracheid length in conifer stems. Australian Forestry, v. 15, p.17-30. 1951.

BOARDMAN, R; CROMER, R.N.; LAMBERT, M.J.; WEBB, M.J. Forest planations. In: REUTER, D.J.; ROBINSON, J.B.. Plant Analysis an Interpretation Manual. Collingwood: CSIRO, 1997. cap.10, p.505-566.

BRASIL, M.A.B. Variação da densidade básica da madeira de Eucalyptus propinqua Deane ex Maiden em função do local e do espaçamento. Piracicaba, 1972. 75p. Dissertação (Mestrado) - Escola Superior de Agricultura "Luiz de Queiroz", Universidade de São Paulo.

BRITO, J.O. Influência da adubação mineral nas características dos anéis de crescimento da madeira de Pinus caribaea Var. bahamensis. Piracicaba, 1985. 113p. Tese (Doutorado) - Escola Superior de Agricultura "Luiz de Queiroz", Universidade de São Paulo.

BRIX, H. Effects of nitrogen fertilization on photosynthesis and respiration in Douglas Fir. Forest Science, v. 17, p.407-414. 1971.

BRIX, H.; MITCHELL, A. K. Effects of thinning and nitrogen fertilization on xylem development in Douglas-fir. Canadian Journal of Forest Research, v.10, n.2, p. $121-128.1980$. 
CAMARGO, M.A.F. Matéria seca, concentração e conteúdo de macronutrientes em mudas de clones de eucalipto, em função da idade. Piracicaba, 1997. 94p. Dissertação (Mestrado) - Escola Superior de Agricultura "Luiz de Queiroz", Universidade de São Paulo.

COLEMAN, R.G.; RICHARDS, F.J. Physiological studies in plant nutrition. XVIII Some aspects of nitrogen metabolism in barley and other plants in relation to potassium deficiency. Annals of Botany, v.20, n.2, p.393-409, 1956.

CROCOMO, O. J.; CATTINI, M.A.; ZAGO, E.A. Acúmulo de aminas e aminoácidos em relação ao nível de potássio em folhas de feijão (Phaseolus vulgaris). Arquivos de Biologia e Tecnologia, v.17, n. 1, p.93-102, 1974 b.

CROCOMO, O.J.; BASSO, L.C. Accumulation of putrescina and related aminoacids in potassium deficient Sesamun. Phytochemistry, v.13, p. 2659-2665, 1974a.

CROMER, R.N.; CAMERON, D.; CAMERON, J.N.; FLINN, D.W.; NEILSEN, W.A.; RAUPACH, M.; SNOWDON, P.; WARING, H.D. Response of eucalypt species to fertilizer applied soon after planting to several sites. Australian Forestry, v. 44, n.1, p.3-13.1981.

CROMER, R.N.; WHEELER, A.M.; BARR, N.J. Mineral nutrition and growth of Eucalyptus seedlings. New Zealand Journal of Forestry Science, v.14, n.2, p.22939, 1984.

CUTTER, B.E.; MURPHY, W.K. Effects of potassium on growth and wood anatomy of Populus hybrid. Wood and Fiber, v.9, n. 4, p.282-288. 1978.

DELL, B. Copper nutrition of Eucalyptus maculata Hook seedlings: requeriments for growth distribution of coopper and diagnosis of copper deficiency. Plant and Soil, v.167, n.2, p.181-187. 1994. 
DELL, B.; MALAJACZUK, N.; GROVE, T.S. Nutrient disorders in plantation eucalypts. Camberra: Australian Centre for International Agricultural Research, 1995. 104p.

DOWNES, G.; TURVEY, N.D. Reduced lignification in Pimus radiata D. Don. Australian Forest Research, v.16, n.4, p.317-377. 1986.

DUBOIS, M.; GILLES, K.A.; HAMLLTON, J.K.; REBERS, P.A.; SMITH, F. Colorimetric method for determination of sugars and related substances. Analytics chemical, v.28, n.3, p.350-356. 1956.

DUNISCH, O.; BAUCH, J.; MULLER, M. GREIS, O. Subcellular quantitative determination of $\mathrm{K}$ and $\mathrm{Ca}$ in phloem, cambium, and xylem cells of spruce (Picea abies [L.] Karst.) during earlywood and latewood formation. Holzforschung, v.52, n. 6, p.582-588. 1998.

EKLUND, L; ELIASSON, L. Effects of calcium ion concentrations on cell wall synthesis. Journal of Experimental Botany, v.41, n.228, p.863-867, 1990.

ELLET, C.W. Soil Fertility and Disease Development. Better crops with plant food, v. 57, p. 6-8, 1973.

EPSTEIN, E. Nutrição Mineral de Plantas; princípios e perspectivas: São Paulo: EDUSP, 1975. 341p.

EVANS, P.T.; MALMBERG, R.L. Do polyamines have roles in plant development? Annual Review of Plant Physiology and Plant Molecular Biology, v.40, p.235269, 1989.

FASSBENDER, H.W. Química de suelos com enfasis en suelos de America Latina. San José: Instituto Interamericano de Ciencias Agricolas, 1980. 398p.

FERREIRA, M.; KAGEYAMA, P.Y. Melhoramento da densidade básica da madeira de eucalipto. IPEF, v.26, n.20, p.1.14, 1978. 
FLORES, H.E.; GALSTON, A.W. Analysis of polyamines in higher plants by high performance liquid chromatography. Plant Physiology, v.69, n.4, p.701-706, 1982.

FOELKEL, C.E.B.; BARRICHELLO, L.E.G. MILANEZ, A.F. Estudo comparativo das madeiras de Eucalyptus saligna, Eucalyptus paniculata, Eucalyptus citriodora, Eucalyptus maculata, Eucalyptus tereticornis para a produção de celulose sulfato. IPEF, n.10, p.17-37, 1975.

FONSECA,S.; MALUF,J.L.P.; OLIVEIRA, A.C. Adubação com boro e zinco de Eucalyptus camaudulensis em solos de cerrado na região de Brasilândia. In: CONGRESSO FLORESTAL BRASILEIRO. 6., Curitiba, 1993. Resumo de Trabalhos Voluntários.Curitiba: Sociedade Brasileira de Silvicultura, 1993. p.69.

FREDERICK, D.J.; MADGWICK, H.A.I.; JURGENSEN, M.F.; OLIVER, G.R. Dry matter content and nutrient distribution in na age series of Eucalyptus regnans plantations in New Zealand. New Zealand Journal Forestry Science, v.15, n.2, p.158-179. 1985.

GALO, M.V. Resposta do eucalipto à aplicação de potássio em solo de cerrado. Viçosa, 1993. 40p. Dissertação (Mestrado) - Universidade Federal de Viçosa.

GALSTON, A. W. Polyamine and plant response to stress. In: BACHRACH, U.; HEIMER, Y. (Eds.). The physiology of polyamines. Boca Raton: CRC Press, 1989. v. 2 , cap. 7, p.99-106.

GALSTON, A. W.; KAUR-SAWHNEY, R. Polyamines in plant physiology. Plant Physiology, v.94, n.2, p.406-410, 1990.

GAVA, J.L. Efeito da adubação potássica em plantios de E. grandis conduzidos em segunda rotação em solos com diferentes teores de potássio trocável. Série Técnica IPEF, v. 11, n.30, p.84-94. 1997 
GENTLE, S.W.; BAMBER, R.K.; HUMPHNEYS, F.R. Effect of two phosphate fertilizers on yield, financial yield, and wood quality of radiata pine. Forest Science, v.14, n.3, p.282-286, 1968.

GRAY, R.L.; ZEEUW, C. Effects of potassium fertilizer on the wood density and related anatomical characteristics of Red Pine wood. In: PROCEEDING, 22 ND NORTHEASTERN FOREST TREE IMPROVEMENT CONFERENCE 1974. 1975. p.72-110.

HAAG, H.P.; SARRUGE, J.R.; OLIVEIRA, G.D.; POGGIANI, F.; FERREIRA, C.A. Análise Foliar de cinco espécies de Eucalyptus. IPEF, n. 13, p.99-115, 1976.

HERBERT, M.A. Fertilizers and eucalypt plantations in South Africa. In: ATTIWILL, P.M.; ADAMS, M.A. (Eds.). Nutrition of Eucalyptus. Collingwood: CSIRO, 1996. p.303-326.

HIGGS, M.L.; RUDMAN, P. The effects of fertilizing and thinning on wood properties of E. regnans. Appita, v.27, n. 1, p.51-55,1973.

HOAGLAND, D.R.; ARNON, D.I. The water-culture method for growing plants without soil. Circular. California Agriculture Experimental Station. Berkely, n.347. 1950 .

HOUMAN, F.; GODBOLD, D. L.; MAJCHERCZYK, A.; SHASHENG, W.; HÜTTERMANN, A. Polyamines in leaves and roots of Populus maximowiczii grown in differing levels of potassium and phosphorus. Canadian Journal Forest Research, v.21, n.12, p.1748-1751, 1991.

HUBER, D.M.; ARNY, D.C. Interactions of potassium with plant disease. In: MUNSON, R.D. (Ed.). Potassium in Agriculture, Madison: ASA, CSSA and SSA, 1985. p.467-488.

HUBER, S.C. Role of potassium in photosynthesis an respiration. In: MUNSON, R.D. (Ed.). Potassium in Agriculture, Madison: ASA, CSSA and SSA, 1985. p.369-391. 
HUORAN, W.; WENLONG, Z; Fertilizer and eucalypt plantations in China. In: ATTIWILL, P.M.; ADAMS, M.A. (Eds.). Nutrition of Eucalyptus. Collingwood: CSIRO, 1996. p.143-149.

JIAN JU, L., CAO, L., LIN, J.A., SHANHUA, W.; LUO, J.J.; Cao, L. Yang, J.L.; Wei, S.H. Effects of fertilization treatments on contents of wood chemical components of Eucalyptus urophylla. Scientia-Silvae Sinicae, v.34, n.5, p.96-102, 1998.

JOZSA, L.A.; BRIX, H. The effects of fertilization and thinning on wood quality of a 24 year old Douglas-fir stand. Canadian Journal of Forest Research, v.19, n.9, p.1137-1145.1989.

JUDD, T.S. Simulated nutrient losses due to timber harvesting in highly productive eucalypt forests and plantations. In: ATTIWILL, P.M.; ADAMS, M.A.(Eds). Nutrition of Eucalyptus. CSIRO Australia. 1996. p. 249-258.

KABATA PENDIAS, A; PENDIAS, H. Trace elements in soils and plants. Boca Raton: CRC Press, 1984. 315p.

KAUL, O.N.; SRIVASTAVA, P.B.L.; BORA, N.K.S. Nutrition studies on Eucalyptus. I. Diagnosis of mineral deficiencies in Eucalyptus Hybrid seedlings. Indian Forester, v.92, n.4, p. 264-268. 1966.

KAUL, O.N.; SRIVASTAVA, P.B.L.; NEGI, J.D.S. Nutrition studies on Eucalyptus. V. Diagnosis of mineral deficiencies in Eucalyptus citriodora seedlings. Indian Forester, v.96, n.10, p.787-90, 1970 b.

KAUL, O.N.; SRIVASTAVA, P.B.L.; TANDON, V.N. Nutrition studies on Eucalyptus. III. Diagnosis of mineral deficiencies in Eucalyptus grandis seedlings. Indian Forester, v.94, n.11, p.831-34, 1968. 
KAUL, O.N.; SRIVASTAVA, P.B.L.; TANDON, V.N. Nutrition studies on Eucalyptus. IV. Diagnosis of mineral deficiencies in Eucalyptus globulus seedlings. Indian Forester, v.96, n.6, p.453-56, 1970a.

KAUNISTO, S.; SARJALA, T. Critical needle potassium concentration indicated by diamine putrescine in Norway spruce growing on peat soils. Silva Fennica, v.31, n.4, p.383-390, 1997.

KAUR- SAWHNEY, R.; GALSTON, A. W. Physiological and biochemical studies on the antisenescence properties of polyamines in plants. In: SLOCUM, R. D.; FLORES, H. E. (Eds): Biochemistry and Physiology of Polyamines in Plants. Boca Raton: CRC Press, cap.14, p. 201-211, 1991.

KNIGTH, P.J. Seasonal fluctuations in foliar nutrient concentration in a young nitrogendeficient stand of Eucalyptus fatigata with and without applied nitrogen. New Zealand Journal of Forestry Science, v.18, n. 1, p.15-32, 1988.

KÖNIGSHOFER, H. Distribution and seasonal variation of polyamines in shoot-axes of spruce (Picea abies (L.) Karst). Journal Plant Physiology, v. 137, n.5, p. 607-612, 1991.

KÖNIGSHOFER, H. Polyamine content in needles, shoot-axes, buds and xylem exudates of mature spruce trees (Picea abies (L.) Karst). Journal Plant Physiology, v. 136, n. 3, p. $377-380,1990$.

KÖNIGSHOFER, H. Seasonal changes in polyamine content in different parts of juvenile spruce trees (Picea abies (L.) Karst). Journal of Plant Physiology, v. 134, n.6, p. $736-740,1989$

LAUCHERT, U.; WILD, A. Studies on the correlation of putrescine and potassium contents in the needles of spruce trees. Journal of Plant Physiology, v.147, n.2, p.267-269, 1995 . 
LEITE, F.P.; BARROS, N.F.; NOVAIS, R.F.; FABRES, A.S. Acúmulo e distribuição de nutrientes em Eucalyptus grandis sob diferentes densidade populacionais. Revista Brasileira de Ciência do Solo, v.22, n.3, p.419-426, 1998.

LINDSTROM, H. Basic density of Norway spruce. Part II. Predicted by stem taper, mean growth ring width, and factors related to crown development. Wood and Fiber Science, v.26, n.2, p.240-251, 1996.

LITTLE, C.H.A.; SAVIDGE, R.A. The role of plant growth regulators in forest tree cambial growth. Plant Growth Regulators, v.6, n. 1/2, p.137-169. 1987.

MADGWICK, H.A.I.; BEETS, P.; GALLAGHER, S. Dry matter accumulation, nutrient and energy content of the above ground portion of 4-year-old stands of Eucalyptus nitens and Eucalyptus fastigata. New Zealand Journal of Forestry Science, v.11, n.1, p.53-59, 1981.

MAKI, H.; ANDO, S.; KODAMA, H.; KOMAMINE, A. Polyamines and the cell cycle of Catharanthus roseus cells in culture. Plant Physiology, v. 96, n.4, p.1008-1013, 1991.

Malavolta, E. Elementos da Nutrição Mineral de Plantas. São Paulo: Agronômica Ceres, 1980. 251p.

MALAVOLTA, E. Essências Florestais: Eucalipto e Pinus. In: MALVOLTA, E. Manual de Calagem e Adubação das principais culturas, São Paulo, Ceres, 1987. cap. 10, p. 376-96.

MALAVOLTA, E.; CROCOMO, O.J. Funções do potássio na planta. In: YAMADA, T.; IGUE, K.; MUZILli, O.; USHERWOOD, N.R. (Eds.) Potássio na Agricultura Brasileira. Piracicaba: Instituto da Potassa e Fosfato (EUA), 1982. p.95-162. 
MALAVOLTA, E.; HAAG, H.P.; SARRUGE, J.R.; VENCOVSKY, R.; VALSECCHI, O.; SANTOS, C.L.O. The relation of the concentration of nitrogen, phosphorus and potassium in the substrate and in the foliage to cell wall thickness and cellulose concentration in the xylem of Slash Pine. Academia Brasileira de Ciências, v.38, n. 1, p.173-186, 1966.

MALAVOlTA, E.; VITTI, G.C.; OLIVEIRA, S.A. Avaliação do Estado Nutricional das Plantas: principios e aplicações. 2.ed. Piracicaba: Associação Brasileira para a Pesquisa da Potassa e do Fosfato, 1997. 319p.

MARSCHNER, H. Mineral Nutrition of Higher Plants. San Diego: Academic Press, 1995. 888p.

MELO, H.A. Efeitos da adubação mineral sobre as qualidades da madeira Piracicaba: Relatório Técnico IPEF/ESALQ, 1968. 15p.

MENGEL, K.; KIRKBY, E.A. Principles of Plant Nutrition. Berne: International Potash Institute, 1978. 593p.

MIGLIORINI, A.J. Variação da densidade básica da madeira de Eucalyptus grandis Hill ex. Maiden em função de diferentes níveis de produtividade da floresta. Piracicaba, 1986. 80p. Dissertação (Mestrado) - Escola Superior de Agricultura 'Luiz de Queiroz", Universidade de São Paulo.

MORAES, M.L.T. Variação genética da densidade básica da madeira em progênies de Eucalyptus grandis Hill ex. Maiden e suas relações com as características de crescimento. Piracicaba. 115p. Dissertação (Mestrado) - Escola Superior de Agricultura "Luiz de Queiroz", Universidade de São Paulo.

MORAIS, E.J.; BARROS, N.F.; NOVAIS, R.F.; BRANDI, R.M. Biomassa e eficiência nutricional de espécies de eucalipto em duas regiões bioclimáticas de Minas Gerais. Revista Brasileira de Ciência do Solo, v. 14, n.3, p.353-62, 1990. 
MURTY, K. S.; SMITH, T.A.; BOULD, C. The relation between the putrescine content and potassium status of black currant leaves. Annals of Botany, v.35, n.6877, p.695, 1971.

NOVAIS, R.F.; RÊGO, A.K.; GOMES, J.M. Nível crítico de potássio no solo e na planta para o crescimento de mudas de Eucalyptus grandis W. Hill ex Maiden e de Eucalyptus cloeziana F. MUELL. Revista Árvore, v.4, n.1, p.14-23. 1980.

OGBONNAYA, C.I. Effects of nitrogen sources on the wood properties of Gmelina arborea relevant to pulp and paper production. Forest Ecology and Management: v.56, n. 1-4, p.211-223, 1993.

OGBONNAYA, C.I. Growth and histo-chemical response of Gmelina arborea seedlings to applications of $\mathrm{N}$ and $\mathrm{K}$ fertilizers and their combinations on oxisolic soil. Journal of Tropical Forest Science, v.4, n.4, p.363-378, 1994.

PEREIRA, A.R.; ANDRADE, D.C.; LEAL, P.G.L.; TEIXEIRA, N.C.S. Produção de biomassa e remoção de nutrientes em povoamentos de Eucalyptus citriodora e Eucalyptus saligna cultivados na região do cerrado de Minas Gerais. Revista Floresta, v. 15, n.1/2, p.8-16, 1984.

PERRENOUD, S. Potassium and Plant Health. 2 ed. Berne, International Potash Institute, 1990. 363p.

POGGIANI, F.; ZEN, S.; MENDES, F.S.; SPINA-FRANÇA, F. Ciclagem e exportação de nutrientes em florestas para fins energéticos. IPEF, n.27, p. 17-30, 1984.

PRETTY, K.M. O potássio na qualidade dos produtos agrícolas. In: YAMADA, T.; IGUE, K.; MUZILli, O.; USHERWOOD, N.R. (Eds.) Potássio na Agricultura Brasileira. Piracicaba: Instituto da Potassa e Fosfato (EUA), 1982. p.177-194.

PREZOTTI, L.C. Nível crítico de potássio no solo para produção de mudas de eucalipto. Viçosa, 1985. 45p. Dissertação (Mestrado) - Universidade Federal de Viçosa. 
REIS, M.G.F.; BARROS, N.F.; KIMMINS, J.P. Acúmulo de nutrientes em uma sequência de idade de Eucalyptus grandis W. Hill (ex-Maiden) plantado no cerrado em duas áreas com diferentes produtividades em Minas Gerais. Revista Árvore, v. 11, n. 1, p.1-15, 1987.

RELATÓRIO ESTATÍSTICO FLORESTAL. Associação Nacional dos Fabricantes de Papel e Celulose. São Paulo. 1996. 60p.

RICHARDS, F. J.; COLEMAN, R.G. Occurrence of putrescine in potassium-deficient barley. Nature, v.170, n.4324, p.460, 1952.

ROCHA FILHO, J.V.C.; HAAG, H.P.; OLIVEIRA, G.D. Deficiência de macronutrientes, boro e ferro em Eucalyptus urophylla. Anais da Escola Superior de Agricultura "Luiz de Queiroz", v.35, n.35, p.19-34, 1978.

ROCHA, M.G.B.; BRUNE, A.; DELLA LUCIA, R.M. Variação da densidade básica e correlações entre progênies jovens de Eucalyptus grandis Hill ex. Maiden, em duas etapas de crescimento. Revista Árvore, v.7, n. 2, p.154-164, 1983.

SARJALA, T. Growth, potassium and polyamine concentration of Scots pine seedlings in relation to potassium availability under controlled growth conditions. Journal of Plant Physiology, v. 147, n. 5, p. 593-598, 1996.

SARJALA, T.; KAUNISTO, S. Effect of different potassium sources on the seasonal variation of potassium and free polyamines in Scots pine needles. Silva Fennica, v.30, n. 4 , p.387-398, 1996.

SARJALA, T.; KAUNISTO, S. Needle polyamine concentration and potassium nutrition in Scot pine. Tree Physiology, v.13, n. 1, p.87-96, 1993.

SARRUGE, J.R. Soluções nutritivas. Summa Phytopathologica, v. 1, p.231-233, 1975. 
SCATOLINI, F.M.; FIRME, D.J.; GARCIA, C.H.; GOMES, F.P.; CAMARGO, F.R. Parcelamento da adubação potássica em E. grandis em áreas de reforma da Votorantim Celulose e Papel (compact disc). In: CONGRESSO LATINO AMERICANO DE CIÊNCIA DO SOLO, 13, Águas de Lindóia, 1996. Solo-suelo 96: trabalhos. Piracicaba: SBCS/SLCS. 1996.

SCHIMIDT, D.V.C. Crescimento de mudas de Eucalyptus camaldulensis e Eucalyptus grandis em resposta à fertilização potássica e a calagem. 1995. 57p. Dissertação (Mestrado), Universidade Federal de Viçosa.

SCHONAU, A.P.G. The effects of fertilizing on the foliar nutrient concentrations in Eucalyptus grandis. Fertilizer Research, v.2, n.2, p.73-87, 1981.

SGARBI, F.; BRITO, J.O.; SILVEIRA, R.L.V.A. Características químicas, físicas e dimensões das fibras da madeira juvenil de Eucalyptus grandis x Eucalyptus urophylla cultivado na omissão de macronutrientes e boro em solução nutritiva. Piracicaba: Relatório Técnico IPEF/ESALQ, 1999.29p.

SGARBI, F.; SILVEIRA, R.L.V.A.; TAKAHASHI, E.; CAMARGO, M.A.F. Crescimento e produção de biomassa de clone de Eucalyptus grandis $\mathrm{x}$ Eucalyptus urophylla em solução nutritiva com omissões de macronutrientes, boro e zinco. In: IUFRO CONFERENCE ON SILVICULTURE AND IMPROVEMENT OF EUCALYPTUS, Salvador, 1997. Anais da Conferência IUFRO sobre Silvicultura e Melhoramento de Eucaliptos, v.3: Silvicultura, produtividade e utilização de eucaliptos. Salvador, 1997. p.92-97.

SHEPARD Jr, R.K. Fertilization effects on specific gravity and diameter growth of red spruce (Picea abies) . Wood Science, v. 14, n.3, p.138-144, 1982.

SHEPARD, R.K.; SHOTTAFER, J.E. Effects of fertilization on specific gravity and growth rate of red spruce (Picea rubens Sarg.). Wood Science, v. 12, n.2, p. 100-102, 1979 
SIDDIQUI, K.M. Influence of fertilization on the ultrastructure and chemical composition of wood. 1972. 161p. Tese (Doutorado) - University Syracuse.

SILVA, H.D.; POGGIANI, F.; COELHO, L.C. Biomassa, concentração e conteúdo de nutrientes em cinco espécies de Eucalyptus plantadas em solos de baixa fertilidade. Boletim Pesquisa Florestal, n.6/7, p.9-25. 1983.

SILVEIRA, R. L. V. A.; GONÇALVES, J. L. M.; GONÇALVES, A. N.; BRANCO, E. F. Levantamento e estudo do mercado e uso de fertilizantes em florestas brasileiras. Piracicaba, Relatório técnico, IPEF/ESALQ.1995c. 117p.

SILVEIRA, R.L.V.A.; GONÇALVES, A.N.; SILVEIRA, R.I.; BRANCO, E.F. Levantamento nutricional de florestas de E. grandis da região de Itatinga/SP. II. Micronutrientes. In: CONGRESSO BRASILEIRO DE CIÊNCIA DO SOLO, 25, Viçosa, 1995d. Resumos expandidos, Viçosa: Sociedade Brasileira de Ciência do Solo, 1995d. p.899-901.

SILVEIRA， R.L.V.A.; HIGASHI, E.N.; GONÇALVES, A.N.; MOREIRA, A. Avaliação do estado nutricional do Eucalyptus: Diagnose visual, foliar e suas interpretações (compact disc). In: Simpósio Sobre Fertilização e Nutrição Florestal: Piracicaba, 1999. Simpósio Sobre Fertilização e Nutrição Florestal 99: trabalhos. Piracicaba: IPEF/ESALQ/USP.

SILVEIRA, R.L.V.A.; HIGASHI, E.N.; POMPERMAYER, P.N. Monitoramento Nutricional do Eucalyptus na região de Capão Bonito/SP. Relatório Técnico IPEF/ESALQ, 1998. 92p.

SILVEIRA, R.L.V.A.; LUCA, E. F.; SHIBATA, F. Absorção de macronutrientes pelas mudas de E. grandis em condição de viveiro. In: CONGRESSO BRASILEIRO DE CIÊNCIA DO SOLO, 25, Viçosa, 1995a. Resumos expandidos, Viçosa: SBCS, 1995a. p. 839-41. 
SIL VEIRA, R.L.V.A.; LUCA, E. F.; SHIBATA, F. Absorção de micronutrientes pelas mudas de $E$. grandis em condição de viveiro. In: CONGRESSO BRASILEIRO DE CIÊNCIA DO SOLO, 25, Viçosa, 1995b. Resumos expandidos, Viçosa: SBCS, 1995b. p. 842-45.

SIL VEIRA, R.L.V.A.; TAKAHASHI, E.N.; SGARBI, F.; BRANCO, E.F. Sintomas de deficiência de macronutrientes e boro em híbrido de Eucalyptus grandis x Eucalyptus urophylla em solução nutritiva (compact disc). In: CONGRESSO LATINO AMERICANO DE CIÊNCIA DO SOLO, 13., Águas de Lindóia, 1996. Solo-suelo 96: trabalhos. Piracicaba: SBCS/SLCS. 1996.

SMITH, T.A. L-Arginine carboxylase of higher plants and its relation to potassium nutrition. Phytochemistry, v.2, p.241-245. 1963.

SMITH, T.A. Polyamines. Annual Review of Plant Physiology and Plant Molecular Biology, v.36, p.117-143, 1985.

SMITH, T.A. Putrescine and inorganic and ions. Recent Advances Phytochemistry, v. 18, p. $7-54,1984$.

SOUZA, M.E. Correlação adulto-juvenil para a eficiência nutricional e comportamento de clones de Eucalyptus grandis em dois niveis de fertilidade do solo. Viçosa, 1994. 49p. Dissertação (Mestrado) - Universidade Federal de Viçosa.

SOUZA, V.R.; CARPIM, M.A.; BARRICHELLO, L.E.G. Densidade básica entre procedências, classes de diâmetro e posição em árvores de Eucalyptus grandis e Eucalyptus saligna. IPEF, n. 33, p.63-72, 1986.

STAPE, J.L. Potencial de crescimento de Eucalytpus grandis numa Areia Quartzosa do Estado de São Paulo. In: REUNIÃO BRASILEIRA DE FERTILIDADE DO SOLO E NUTRIÇÃO DE PLANTAS, 20., Piracicaba, 1992. Anais. Piracicaba: Sociedade Brasileira de Ciência do Solo, 1992. p. 172-73. 
STAPE, J.L.; BENEDETTI, V. Decréscimos de produtividade e resposta da brotação de Eucalyptus grandis à fertilização com macronutrientes em areia quartzosa no Estado de São Paulo-Brasil. In: IUFRO CONFERENCE ON SILVICULTURE AND IMPROVEMENT OF EUCALYPTUS, Salvador, 1997. Anais da Conferência IUFRO sobre Silvicultura e Melhoramento de Eucaliptos, v.3: Silvicultura, produtividade e utilização de eucaliptos. Salvador, 1997. p.112-117.

STAPE, J.L.; ZANI FILHO, J. Aumento da produtividade do E. grandis em Areias Quartzosas, através da fertilização de manutenção. In: CONGRESSO FLORESTAL BRASILEIRO, 6., Campos do Jordão, 1990. Trabalhos. Campos do Jordão: Sociedade Brasileira de Silvicultura, 1990. p. 386-390.

STURION, J.A.; PEREIRA, J.C.D.; ALBINO, J.C.; MORITA, M. Variação da densidade básica da madeira de doze espécies de Eucalyptus plantadas em Uberaba, MG. Boletim de Pesquisa Florestal, n. 14, p.29-38, 1987.

SUBRAHMANYAM, S.V. Effect of nitrogen and phosphorus on fibre morphology of Eucalyptus grandis. Advances in Forestry Research in India, v. 1, p.207-215, 1988.

SUNDBERG, B.; ERICSSON, A.; LITTLE, LITTLE, C.H.A.; NASHOLM, T.; GREE, $\mathrm{R}$. The relationship between crown size and ring width in Pinus sylvestris L. Stems: dependence on indole acetic acid, carbohydrates and nitrogen in the cambial region. Tree Physiology, v. 12, n.4, p.347-362, 1993.

TEIXEIRA, J.L.; BARROS, N.F.; COSTA, L.M.; CAMPOS, J.C.C.; LEAL, P.G.L. Biomassa e conteúdo de nutrientes de dua espécies de eucalipto em diferentes ambientes do médio Rio Doce, MG. Revista Árvore, v.13, n. 1, p.34-50.1987.

TOKESHI,F.; GUIMARÃES, R. F.; TOMAZELLO FILHO, M. Deficiência de boro em Eucalyptus em São Paulo. Summa Phytopathologica, v.2, n.2, p. 122-126. 1976.

TOMAZELLO FILHO, M. Variação radial da densidade básica e da estrutura anatômica da madeira de Eucalyptus saligna e E. grandis. IPEF, n.29, p.37-45, 1985. 
VALE, A.T.; MOURA, V.P.G.; MARTINS, I.S.; REZENDE, D.C.A. Densidade básica média, em função da profundidade de penetração do pino do "pilodyn" e da classe diâmetrica, e variação axial da densidade básica em Eucalyptus grandis Hill ex. Maiden. Revista Árvore, v. 19, n. 1, p.80-91, 1995.

VALERI, S.V. Efeito do fósforo e do cálcio no desenvolvimento de Eucalyptus grandis em um regossolo. Jaboticabal, 1983. 129p. Dissertação de mestrado, Universidade Estadual Paulista.

VALERI, S.V.; CORRADINI, L.; AGUIAR, I.V. Efeitos de níveis de NPK e calcário dolomítico na produção volumétrica de madeira de Eucalyptus grandis Hill ex Maiden. Científica, v.19, n. 1, p. 63-70, 1991.

VALERI, S.V.; ISMAEL, J.J. TORRES, R.M.; CORRADINI, L. Efeito do potássio no crescimento e idade de corte de povoamentos de Eucalyptus grandis, em areia quartzosa e latossolo vermelho escuro (compact disc). In: CONGRESSO LATINO AMERICANO DE CIÊNCIA DO SOLO, 13., Águas de Lindóia, 1996. Solo-suelo 96: trabalhos. Piracicaba: SBCS/SLCS. 1996.

WEETMAN, G.F. Effects of thinning and fertilization on the nutrient uptake, growth and wood quality of upland Black Spruce. Otawa: Pulp Paper Research Institute Canadian, n.28, 1971. 18p.

WILL, G.M. Some change in the growth habit of Eucalyptus seedlings caused by nutrient deficiencies. Empire Forestry Review, v.40, n.4, p. 301-307, 1961.

WILLIANS, R.F.; HAMILTON, J.R.; The effect of fertilization on four wood properties of slash pine. Journal Forestry, v.59, n.9, p.662-665, 1961.

WOOLLONS, R.C.; CRANE, W.J.B; SNOWDEN, P. Response to nitrogen, phosphorus and sulfur applications to a Pinus radiata stand in the Tumut region, New South Wales. Australian Forestry, v.58, n.3, p. 135-141, 1995. 
YANG, R.C.; WANG, E.I.C.; MICKO, M.M. Effects of fertilization on wood density and tracheid length of 70 year-old loggeople pine in West Central Alberta. Canadian Journal of Forest Research, v.18, n.7, p.954-956. 1988.

YORDANOV, T.S.; SKOVA, T.G. Effect of mineral fertilizing on the macroscopic structure and density of Scots pine wood. Gorsko Stopanstvo, v.45, n.5, p.6-9, 1989.

YOST, R.S.; DE BELL, D.S.; WHITESELL, C.D.; MIYASAKA, S.C. Early growth and nutrient status of Eucalyptus saligna as affected by nitrogen and phosphorus fertilization. Australian Forest Research, v.17, n.3, p.203-214. P. 1987.

ZAIDAN, H. A.; BROETTO, F.; OLIVEIRA, E.; GALLO, L. A.; CROCOMO, O. T. Influence of potassium nutrition and the nitrate/ammonium ratio on the putrescine and spermidine contents in banana vitroplants. Journal of Plant Nutrition, v.22, n.7, p.1123-1140, 1999.

ZJACZKOWSKI, S. Auxin stimulation of cambial activity in Pinus sylvetris. The differential cambial response. Plant Physiology, v.29, n.3, p.281-287.1973.

ZOBEL, B.J.; GOGGANS, J.F.; MAKI, T.E.; HENSON, F. Some effects fertilizers on wood properties of loblolly pine. Tappi, v.4, n.3, p.186-192. 1961. 